UNIVERSIDADE DE SÃO PAULO

INSTITUTO DE GEOCIÊNCIAS

\title{
ESTUDO GEOLÓGICO-GEOCRONOLÓGICO DOS TERRENOS GRANITO-GNÁISSICOS E SEQUÊNCIAS METAVULCANOSSEDIMENTARES DA REGIÃO DO BETARA (PR).
}

Ligia Maria de Almeida Leite Ribeiro

Orientador: Prof. Dr. Oswaldo Siga Júnior

DISSERTAÇÃO DE MESTRADO

Programa de Pós-Graduação em Geoquímica e Geotectônica

SÃO PAULO

2006 
Se cada dia cai, dentro de cada noite, há um poço onde a claridade está presa.

há que sentar-se na beira do poço da sombra e pescar luz caída com paciência.

Pablo Neruda (Últimos Poemas)

Dedico todo este esforço aos meus familiares e colegas, aqueles que me acompanham nesta infinita caminhada de cada dia, pois afinal de contas ninguém é feliz sozinho! 


\section{ABSTRACT}

The Betara region was located at nothwest of the Curitiba City between the Campo Largo and Rio Branco do Sul municipal districts.

This region includes granite-gnaissic rocks, proto to milonitics (Betara Nucleous) and metavolcanossedimentary sequences with low to intermediate metamorphic grade (Betara Formation). These terrains occur at the southern portion of the Ribeira Belt, surrounded by metavolcanossedimentary sequences of the Votuverava Formation.

The main objective of this work was realize geologic-geochronologic studies (U-Pb zircon) of metabasic rocks associated with the metavolcanossedimentary sequences (Betara Formation), as well the metabasic rocks associated with the proto milonitic to milonitic granite-gnaissic terrains (Betara Nucleous).

At the center-southern portion of the Betara Region, was recognized granodioritic rocks, proto to milonitic formed during the Paleoproterozoic ( 2200 Ma) with archean inheritances (zircon nucleous $\sim 2800 \mathrm{Ma})$. Archean values ( 3200Ma) where obtained with Sm-Nd (TDM) method. This values where indicative for the mantle carries away ages for the crustal protolites of these rocks.

These terrains are limited at the south by the Lancinha Shear Zone, who separates the Apiaí Domain (north) from the Atuba Complex (south).

In this tectonic context, the proto to milonitc ganodioritic terrains represents peaces from the basement and possibly can be related to the Paranapanema Cratonic Region.

This correlations are not a simple work and the geologic propers with the geologic patterns was to close to that observed for the Setuva Nucleous (Siga Júnior et al., 2006 no prelo) and for the Atuba Complex ( Siga Júnior et al., 1995 e Sato et al., 2003).

In tectonic contact with the granodioritic terrains occurs some sienogranitic rocks proto to milonitics associated with metabasic rocks (magma mixing and/or magma mingling). The $\mathrm{U}-\mathrm{Pb}$ zircon values obtained to the sienogranitic rocks was related to the Upper Paleoproterozoic (1780-1750 Ma; Kaulfuss, 2001 e Cury et al., 2003), very close to the ages obtained for the metabasic rocks (U-Pb zircon at 1789+-22 Ma).

The occurrence of the sienogranitic rocks associated with metabasic rocks; with anorogenic characteristics may imply extensional systems and represents an important 
frame on this region, related to the Estatherian Tafrogenetic Event. Increases the possibilities to occur some sedimentation associated to this anorogenic magmatism, related to rift type basins developed during this period. Ages from this interval (1800 - $1600 \mathrm{Ma})$ occurs at the Apiaí Belt for the sienogranites proto to milonitics from the Tigre Nucleous at the south of the Passa Tres granitic body and at the nothwesthern portion of the granitic bathollite Três Córregos (Kaulfuss, 2001; Cury et al., 2003 e Prazeres Filho, 2005).

In the South American Continent was recognized at a great part of this center west portion (Borborema Province, Espinhaço System, São João Del Rei Group, Tocantins Province and Ribeira Belt) according with Brito Neves et al. (1995). This tafrogenetic record was relatively synchronic, but variate in magnitude and extension and at most part of the time was related to crustal rifts with alkaline to sub alkaline magmatism associated with siliciclastic sedimentation. Might represent important scars associated with the breakage of some large continental masses agglutinated during the Paleoproterozoic (Atlantica Suercontinent, Rogers, 1996) or as same during the Paleo-Mesoproterozoic (Columbia Supercontinet; Rogers and Santos, 2002; Zhao et al., 2004).

The geologic studies of the metavolcanossedimentary sequences (Betara Formation) in tectonic contact with sienogranitic-granodioritic terrains (Betara Nucleous) admit to recognize three major units: Metapsamitic sequence (lower), recognized mainly by quartzites, a marble, calciossilicatic and marly sequence (intermediary) and a metapelitic sequence (upper) where predominate phyllites associated with metabasic rocks.

The geochronological data obtained from the U-Pb (zircon) method refers to metabasic rock bodies (dikes or sills) who occurs in conformity and intercalated with the upper pelitic sequence.

The geochemical studies of this bodies indicates this ortho derived nature and a subalkaline chemical characteristics who suggests a distensive ambient.

The ages obtained in a range between 1500-1450 Ma can be interpreted like minimal ages to deposition for the Betara Formation.

Values at this same range (1450-1500 Ma) were obtained recently to the Votuverava, Perau and Água Clara Formations. The Mesoproterozoic represents an important frame related to deposition of the great part of the metavolcanossedimentary sequences of the southern Ribeira Belt. 
The geologic-geochronologic patterns, with the structural patterns observed to the Betara Region suggests whom the placement of this terraines at the upper crustal levels occurs at the Neoproterozoic, function of a shear-controlled tectonics. 


\section{RESUMO}

A Região do Betara, objeto desta pesquisa, localiza-se a nordeste da Cidade de Curitiba, entre os Municípios de Rio Branco do Sul e Campo Largo. Inclui Rochas garanito-gnáissicas proto a miloníticas (Núcleo Betara) e seqüências metavulcanossedimentares de baixo a médio grau metamórfico (Formação Betara). Esses terrenos ocorrem na porção sul da Faixa Ribeira, em meio a seqüências metavulcanossedimentares da Formação Votuverava.

Este trabalho teve como objetivo principal realizar estudos geológico-geocronológicos (U$\mathrm{Pb}$ zircão) de rochas metabásicas associadas à seqüências metavulcanossedimentares (Formação Betara), bem como dos terrenos granito-gnáissicos proto a miloníticos (Núcleo Betara).

$\mathrm{Na}$ região centro-sul do Betara, foram reconhecidas rochas granodioríticas proto a miloníticas formadas durante o paleoproterozóico ( 2200 Ma) com heranças (núcleos de zircões) arqueanas ( 2800 Ma). Valores arqueanos ( 3200 Ma) foram obtidos através do método Sm-Nd (TDM) indicativos da época de derivação do manto dos protolitos crustais dessas rochas. Estes terrenos são limitados a sul pela Zona de Cisalhamento Lancinha, que baliza o domínio da Faixa Apiaí (à norte) daquele pertencente ao Complexo Atuba (a sul). Neste contexto tectônico, os terrenos granodioríticos proto à miloníticos representam lascas de embasamento, possivelmente relacionadas ao cráton do Paranapanema. Tal correlação, no entanto, não é tarefa fácil, uma vez que as características geológicas acopladas ao padrão geocronológico são bastante similares às observadas para o Núcleo Setuva (Siga Júnior et al., 2006 no prelo) e para o Complexo Atuba ( Siga Júnior et al., 1995 e Sato et al., 2003).

Em contato tectônico com os terrenos granodioríticos ocorrem rochas sienograníticas proto a miloníticas, intimamente associadas a rochas metabásicas (mistura de magmas - mixing, mingling). Os valores U-Pb (zircão) obtidos para os litotipos sienograníticos referem-se ao paleoproterozóico superior (1780 - 1750 Ma; Kaulfuss, 2001 e Cury et al., 2003), similar às idades aqui obtidas para as rochas metabásicas (U-PB, zircão de 1789+-22 Ma). A ocorrência de rochas sienograníticas associadas a rochas metabásicas, com características anorogências, sugestivas de regimes extencionais representa um importante marco na região, relacionado à Tafrogênese Estateriana. Acrescente-se ainda a possibilidade de haver sedimentação associada a esse magmatismo 
de natureza anorogênica, relacionado a bacias do tipo rift desenvolvidas nesse período. Idades desse intervalo (1800 - $1600 \mathrm{Ma}$ ) ocorrem no âmbito da Faixa Apiaí, em rochas sienograníticas proto à miloníticas do Núcleo do Tigre, a sul do corpo granítico Passa Três e no setor NE do batólito granítico Três Córregos (Kaulfuss, 2001; Cury et al., 2003 e Prazeres Filho, 2005). No continente Sul-Americano são reconhecidos ao longo de grande parte de sua porção centro-oriental (Província Borborema, Sistema Espinhaço, Grupo São João Del Rei, Província Tocantins e Faixa Ribeira), conforme discutido em Brito Neves et al. (1995). Esses registros tafrogenéticos, embora relativamente sincrônicos, variam em magnitude e extensão e são na maioria das vezes, caracterizados como rifts crustais com magmatismo de natureza alcalina ou sub-alcalina e sedimentação siliciclástica associada. Devem representar importantes cicatrizes associadas à rupturas de grandes massas continentais aglutinadas durante o Paleoproterozóico (Supercontinente Atlântica - Rogers, 1996), ou mesmo durante o Paleo-Mesoproterozóico (Supercontinente Columbia; Rogers e Santos, 2002; Zhao et al., 2004).

Os estudos geológicos relativos as seqüências metavulcanossedimentares (Formação Betara), em contato tectônico com os terrenos sienograníticos e granodioríticos (Núcleo Betara), permitiram reconhecer três unidades maiores: Sequência metapsamítica (basal) representada principalmente por quartzitos, uma Sequência de mármores, calciossilicáticas e metamargas (intermediária) e uma Sequência metapelítica (superior) onde predominam filitos com metabásicas associadas.

Os dados geocronológicos obtidos através do método U-Pb (zircão) referem-se a corpos de rochas metabásicas (possíveis sills ou diques), que ocorrem intercalados concordantemente com a Sequência pelítica superior. O estudo petrográficos e geoquímicos desses corpos, embora bastante preliminar indica a natureza orto derivada dessas rochas e um quimismo de basaltos subalcalinos sugestivos de ambientes tectônicos distensivos.

As idades obtidas do intervalo de 1500-1450 Ma são aqui interpretadas como mínimas de deposição da Formação Betara, possivelmente próxima desta. Valores de intervalo (1500-1450 Ma.) foram recentemente obtidos para as seqüências metavulcanossedimentares das Formações Votuverava, Perau e Água Clara. O Mesoproterozóico representa portanto, um importante marco relacionado a deposição de grande parte das seqüências metavulcanossedimentares do sul da Faixa Ribeira. 
O padrão geológico-geocronológico aliado ao padrão estrutural observado para a região do Betara, sugere que a colocação desses terrenos a níveis crustais superiores tenha ocorrido durante o Neoproterozóico, função de uma tectônica controlada em grande parte por cisalhamentos 


\section{ÍNDICE:}

ABSTRACT

RESUMO

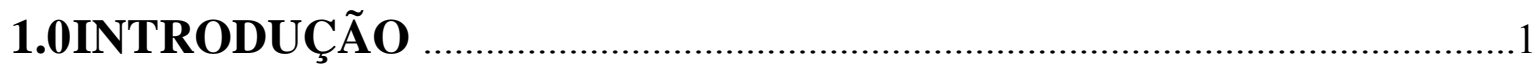

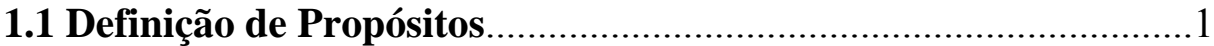

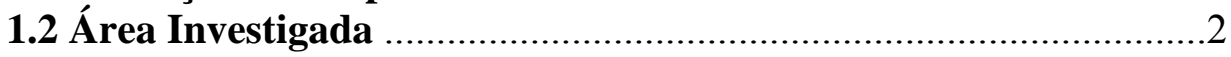

1.3 Evolução dos Conhecimentos........................................................3

1.3.1 Um Breve Histórico dos Trabalhos Realizados no Pré Cambriano

Paranaense - Trabalhos Pioneiros: Fase

Histórica...........................................................................

1.3.2 A Formação Setuva e o Complexo Pré Setuva: Relações com o Grupo Açungui......................................................4

1.3.3 Complexos Pré Setuva, Setuva e Núcleos Betara e Tigre. .6

\subsection{Contexto Geocronológico da Faixa de Dobramentos}

Apiaí

2.0MÉTODOS DE TRABALHO 15

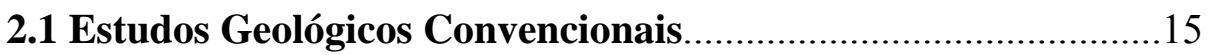

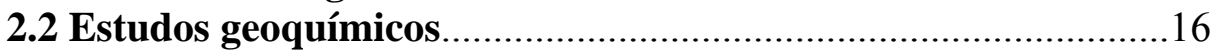

2.3 Metodologias IsotópicUtilizadas..................................................16

2.3.1 Metodologia Isotópica U-Pb (zircão)...................................18

2.3.2 Sistemática Isotópica Sm-Nd............................................25

2.3.3 Metodologia Isotópica Rb-Sr.............................................29

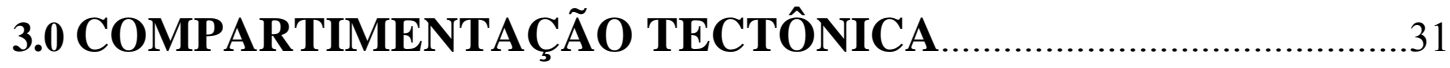

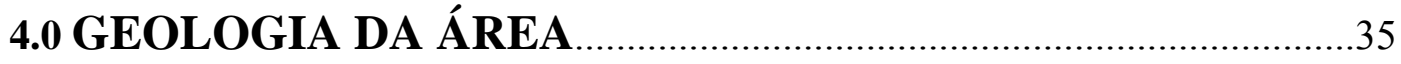

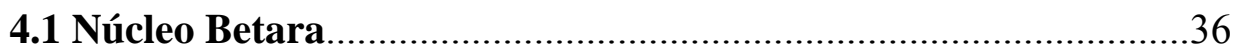

4.1.1 Granodioritos Proto Miloníticos à Miloníticos.....................36

4.1.2 Sienogranitos Miloníticos.................................................37

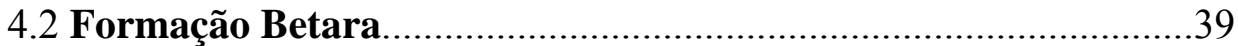

4.2.1 Sequência Metapsamítica (basal).......................................39

4.2.2 Sequência de Mármores, Cálciossilicáticas e Metamargas (intermediária).................................................................40

4.2.3 Sequência Metapelítica (superior)........................................42

\subsection{CARACTERÍSTICAS PETROGRÁFICAS.................................45}

5.1 Aspectos Petrográficos da Sequência Metassedimentar.............45

5.1.1 Sequência Metapelítica (superior)......................................45

5.1.2 Sequência Metacarbonática (intermediária)........................48

5.2 Petrografia das Rochas Metabásicas..............................................57 
6.0ESTUDOS GEOQUÍMICOS

6.1 Comportamento dos Elementos - Diagramas de Variação.........63

6.1.1 Elementos Maiores, Menores e Traços.

6.2 Razões entre Proporções Moleculares (RPM) para elementos maiores

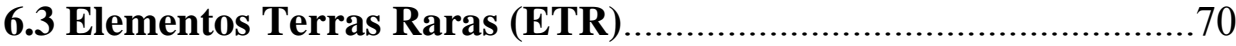

6.4 Gráficos Multielementares Normalizados (Spidergrams)............74

6.5 Diagramas de Classificação.

7.0 CONTEXTO ESTRUTURAL DA REGIÃO DO BETARA.

8.0 ESTUDOS GEOCRONOLÓGICOS.

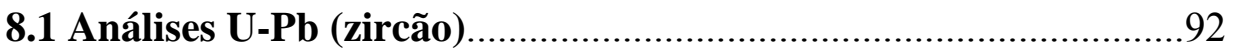

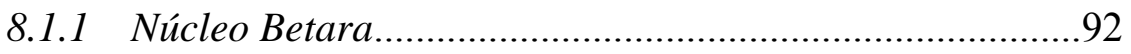

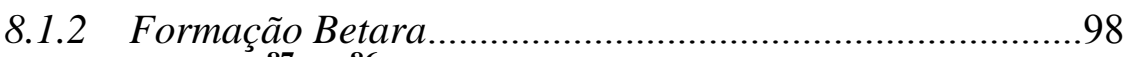

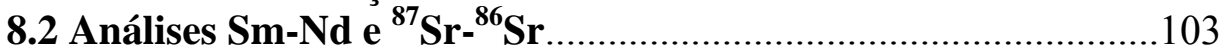

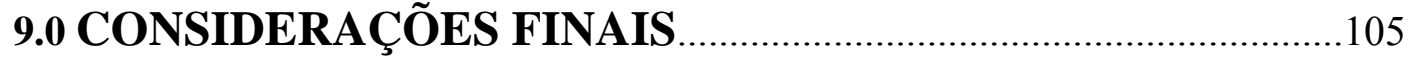

\subsection{REFERÊNCIAS BIBLIOGRÁFICAS ......................................}

\section{Anexo 1}

Tabelas das análies geoquímicas

Anexo 2

Tabelas das Análises Sm-Nd \& Sr-Sr

Anexo 3

Tabela das Análises U-Pb em zircão

Anexo 4

Mapa Geológico - Escala 1: 100.000 


\section{Lista de Figuras:}

\section{Capítulo 1}

Figura 1.1 - Localização e acesso à area de

estudo. 2

\section{Capítulo 3}

Figura 3.1 - Esquema Geológico-Tectonico (Leste do Paraná e Sudeste de São Paulo). 34

\section{Capítulo 4}

Figura 4.1 - Porfiroclastos de feldspatos centimétricos estirados e rotacionados. .36

Figura 4.2 - Micróliton formado pelo próprio milonito estirado e rotacionado em meio a matriz ultramilonítica (LBT-12) .37

Figura 4.3 - Feições de mistura de magmas (mixing/mingling) entre os metabasitos e sienogranitos do Núcleo do Betara (LBT-12). 1- Porção de metabasito "englobada" pelo sienogranito. 2- Feldspatos potássicos do sienogranito englobados no metabasito. 3Pedaços de sienogranito englobados pelo metabasito. 4- Contato entre uma porção do metabasito e uma porção do sienogranito com porções do sienogranito englobadas no metabasito. 39

Figura 4.4 - Mármore com bandamento sugestivo de estratificação primária

Figura 4.5 - Dobras métricas em rocha cálcio-silicática com níveis pelíticos e areno pelíticos. .41

Figura 4.6 - Formação ferrífera com concreções ferruginosas no afloramento LBT38. 
Figura 4.7 - Formação ferrífera no afloramento LBT-38..............................42

Figura 4.8 - Afloramento de Metabasitos (LBT-07).......................................43

\section{Capítulo 5}

Figura 5.1 - Texturas das amostras de muscovita filitos................................46

Figura 5.2 - Quartzo e muscovita nos planos de foliação (LBT-43)..................46

Figura 5.3 - Porfiroblasto de muscovita (LBT-43)..........................................47

Figura 5.4 - Biotitas na amostra LBT-66 (A) Biotitas desenvolvidas paralelamente à Sn (B) e (C) Porfiroblastos de biotita truncando Sn. (D) Diferentes gerações de biotitas. 48

Figura 5.5 - Porfiroblastos de granada na amostra LBT-44B (A) Sn interna ao porfiroblasto.

(B) Porfiroblastos de granada e matriz. .48

Figura 5.6 - Porfiroblasto de granada na amostra LBT-66. .48

Figura 5.7 - Textura mostrando os níveis de quartzo e os níveis carbonáticos da rocha (LBT-63C) 49

Figura 5.8 - Porfiroblasto de dolomita em meio à matriz de carbonato (LBT67B). 49

Figura 5.9 - Clorita magnesiana (LBT-67B) polarizadores cruzados à esquerda e paralelos à direita. 50

Figura 5.10 - Cristais de tremolita com hábito fibroso (LBT-67B).... .50

Figura 5.11 - Textura das diversas amostras. Todas as fotomicrografias acima foram tiradas com objetiva de $1,25 \mathrm{X}$ e nicóis cruzados. .52

Figura 5.12 - Agregado de actinolita intercrescida com clorita (B) na forma de um prisma curto (A) substituindo a pigeonita (piroxênio sub-cálcico). .53 Figura 5.13 - (A) Cristal de actinolita prismático flexionado (A), pseudomorfo do clinopiroxênio ígneo. Actinolita com geminação lamelar simples (B) .54

Figura 5.14 - (A) e (B) Segunda geração de actinolita, com granulação fina e hábito acicular. 54

Figura 5.15 - (A) Textura na interface entre a clinozoisita e cristais de anfibólio mostrando o contato "ripiforme" de cristais de plagioclásio já totalmente substituídos. (B) Veio de quartzo na amostra LBT17A. .55 
Figura 5.16 - Clinozoisita em agregados granulares na matriz. .55

Figura 5.11 - Amostra LBT-7A concentração de albitas na forma de um "veio. No restante da rocha a albita é praticamente ausente (A e B). 56

Figura 5.12 - Amostra LBT-20 concentrações circulares de albita (A e B).......56

Figura 5.13 - Seção basal de turmalina na amostra LBT-17B...........................56

Figura 5.20 - Diagrama ACF para as rochas metabásicas deste estudo. Os campos correspondentes às amostras foram obtidas com as porcentagens dos óxidos maiores encontradas na tabela 6.1 .57

\section{Capítulo 6}

Figura 6.1 - Diagramas de variação para elementos maiores e menores versus

$\mathrm{MgO}$. .65

Figura 6.2 - Diagramas de variação para elementos traço versus

$\mathrm{MgO}$

Figura 6.3 - Gráficos de razões entre proporções moleculares para os elementos maiores .70

Figura 6.4 - Distribuição dos elementos terras raras para as amostras deste estudo. .72

Figura 6.5 - Diagramas multielementares mostrando a composição das rochas deste estudo comparadas com a composição de basaltos de diferentes ambientes tectônicos: (A) Condrito C1, (B) MORB, (C) manto primitivo, (d basaltos de ilhas

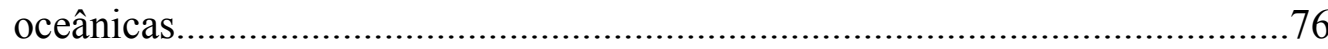

Figura 6.6 - Diagrama álcalis versus sílica de Cox et al. (1979).........................78

Figura 6.7 - Diagrama AFM de Irvine \& Baragar (1971)a - apenas para amostras LBT e bpara demais estudos realizados com rochas metabásicas no pré-Cambriano paranaense (Daitx, 1996; Maniesi, 1997; Frasca, 1990; Weber, 2004) .78

Figura 6.8 - Diagrama de Álcalis versus Sílica de Irvine \& Baragar (1971) a - apenas para amostras LBT e b-para demais estudos realizados com rochas metabásicas no pré- 
Cambriano paranaense (Daitx, 1996; Maniesi, 1997; Weber,

2004. .79

Figura 6.9 - Diagramas SiO2 versus Zr/TiO2*0.0001 de Wynchester \& Floyd (1977) apara amostras deste estudo b- Estudos realizados no Pré Cambriano paranaense (Frasca,1990 e Weber,2004). . .80

\section{Capítulo 7}

Figura 7.1 - Variação granulométrica em margas (S0) afloramento LBT33.

Figura 7.2 - Estratificação cruzada em amostra de quartzito do afloramento LBT01 . 82

Figura 7.3 - Dobra métrica D2 em rochas calciossilicáticas (afloramentoLBT44) .83

Figura 7.4 - Dobra métrica D2 em rochas calciossilicáticas (afloramentoLBT44). 83

Figura 7.5 - Dobras tardias em meta-margas (ponto LBT-67). .84

Figura 7.6 - Diagrama de Schimidt-Lambert (projeção polar) para a Formação Betara no Setor Ocidental. Mostra Sn de baixo à médio ângulo afetada por um dobramento relativamente cilíndrica (D2) com eixos horizontalizados. Os planos $\mathrm{Sn}+1$ apresentam-se plano-axiais à esses dobramentos. A dispersão observada dos polos de $\mathrm{Sn}$ e $\mathrm{Sn}+1$ somada às observações em campo de ondulações destas superfícies (clivagem ardosiana $\mathrm{Sn}+2$ ) indicam redobramento destas superfícies, com eixos horizontalizados com fracos mergulhos ora para o quadrante NW, ora para o quadrante SE .85

Figura 7.7 - Diagrama de Schimidt-Lambert para a Formação Votuverava. Comportamento estrutural da Formação Votuverava, bastante similar ao observado para a Formação Betara, sugerindo concordância estrutural entre as duas formações (afetadas pelos mesmos eventos deformacionais) .86

Figura 7.8 - Diagrama de Schimidt-Lambert (projeção Polar) para a Formação Antinha. Apesar da pequena quantidade de medidas o estereograma sugere S0 afetada somente pelos 
dobramentos tardios, também presentes nas Formações Betara e

Votuverava.

Figura 7.9 - Diagrama de Schimidt-Lambert (projeção polar) para a foliação Sc nas zonas de cisalhamento (Formação Betara - Setor Oriental) com direção aproximadamente EW e forte caimento para norte e por vezes para sul $\left(60^{\circ}-70^{\circ}\right)$. A dispersão pode ser relacionada a anastomosamentos internos à zona de cisalhamento. Bastante similar ao que Fiori (1990) e Piekarz (1984) observaram nesta região. Importante ressaltar a semelhança com os padrões Sn+1 observados para a Formação Votuverava, denotando concordância estrutural. 89

Figura 7.10 - Esterograma (densidade dos polos) da Sn (baixo à médio ângulo) nos metassedimentos (Formações Votuverava e Betara) adjacentes às intrusões dos granitos (Cerne, Passa Três e Rio Abaixo) - Retirado de Cury (2003) 90

Figura 7.11 - Diagrama de Schimidt-Lambert (projeção polar) para os Sienogranitos e Granodioritos do Núcleo Betara. Polos distribuídos nos quadrantes NW (predominantemente) e SE. Superfícies com mergulhos relativamente elevados, sugerindo forte influência da Zona de Cisalhamentos

Lancinha .90

\section{Capítulo 8}

Figura 8.1 - Zircões da amostra LBT-13. 99

Figura 8.2 - Diagrama concórdia para os zircões da amostra LBT-

13. .92

Figura 8.3 - Análise EV-TIMS de um cristal de zircão com biterminações levemente arredondadas. .94

Figura 8.4 - Análise EV-TIMS de cristal de zircão prismático regular. .95

Figura 8.5 - Análise EV-TIMS de um cristal de zircão prismático

regular...... .96

Figura 8.6 - Zircões da amostra LBT-12 ..............................................97

Figura 8.7 - Diagrama concórdia para a amostra LBT-12 ............................98

Figura 8.8 - Zircões da Amostra LBT-7a .99 
Figura 8.9 - Diagrama concórdia para a amostra LBT-7 a.............................99

Figura 8.11 - Diagrama Concórdia para a amostra LBT-9............................100

Figura 8.12 - Zircões da amostra LBT-20 ...................................................100

Figura 8.13 - Diagrama Concórdia para a amostra LBT-20.........................103

Figura 8.14 - Diagrama isocrônico Sm-Nd

Figura 8.15 - O diagrama $\quad \mathrm{Nd}^{\mathrm{X}} \quad$ sr para as rochas metabásicas da Região do

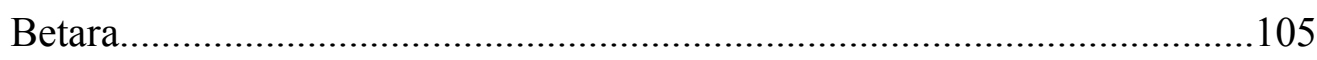

Figura 8.16 - Diagrama ${ }_{\mathrm{Nd}} \mathrm{X} \mathrm{T}$ para as rochas metabásicas da Região do

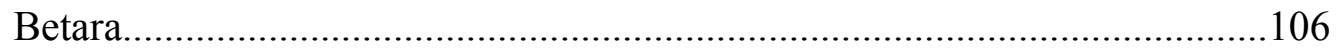




\section{Lista de Tabelas}

\section{Capítulo 6}

Tabela 6.1 - Elementos maiores, menores e traços: rochas metabásicas intercaladas nas sequências metavulcanossedimentares da Formação

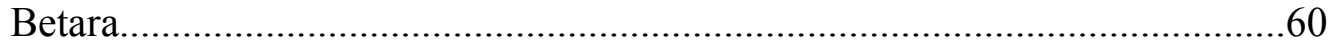

Tabela 6.2 - Elementos terras raras: rochas metabásicas intercaladas nas sequências metavulcanossedimentares da Formação

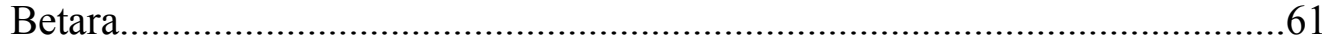

\section{Capítulo 8}

Tabela 8.1 - Valores obtidos para as análises de Sm-Nd das rochas metabásicas da Região do Betara .104

Tabela 8.2 - Valores obtidos para as análises de $\mathrm{Rb}$-Sr das rochas metabásicas da Região do Betara... .105 


\section{AGRADECIMENTOS:}

Gostaria de expressar aqui minha eterna gratidão àqueles que de uma maneira ou de outra contribuiram com este trabalho.

Em primeiro lugar ao Grande Geólogo Supremo, criador do universo e de todas as coisas, por me acompanhar, proteger e principalmente pelas centelhas de entendimento e inspiração que permitiram com que essa pesquisa evoluísse apesar de todas as dificuldades. Em seguida aos meus pais e familiares pelo apoio e incentivo nos estudos, nunca me permitindo desanimar e sempre dando força, direta ou indiretamente, para que eu seguisse adiante.

Ao Prof. Doutor Oswaldo Siga Júnior, meu Orientador, pelo apoio e orientação, além da ajuda irrestrita em todas as fases desta pesquisa, por seu exemplo de trabalho, por sua imensa generosidade. Agradeço principalmente por sua grande paciência e compreensão, permitindo-me a liberdade de fazer as coisas ao meu modo e vindo ao meu auxílio sempre que necessário.

Ao Prof. Doutor Gergely Andres Julio Szabó, que colaborou de maneira fundamental nos estudos petrográficos e geoquímicos desta pesquisa, por seu tempo precioso despendido generosamente nas discussões ao microscópio, na estruturação dos gráficos, montagem dos capítulos, além de todos os esclarecimentos e referências.

Ao colega Leonardo Fadel Cury, por sua presença nas etapas de campo e por todas as dicas e discussões fundamentais para o amadurecimento deste trabalho.

Aos colegas Hélcio José dos Prazeres Filho e Cláudia Regina Passarelli, por seu apoio e incentivo nas fases finais do desenvolvimento desta pesquisa.

A colega Lucelene Martins (Vau) pela ajuda fundamental na petrografia e no tratamento dos dados geoquímicos, além das inúmeras discussões que amadureceram e enriqueceram muito estes capítulos da dissertação.

As colegas da pós graduação Veridiana Teixeira de Souza Martins, Márcia Gomes da Silva, Milene Freitas Figueiredo, Aline Carneiro Silverol pelo grande apoio durante toda a duração desta pesquisa, sempre prontas e com palavras de ânimo sempre fundamentais para seguir adiante.

Ao Centro de Pesquisas Geocronológicas (CPGeo - IGc - USP), onde foi gerado grande parte do volume de dados deste trabalho. Agradeço aos funcionários Vasco A. Loios, 
Solange L. de Souza e Walter M. Sproesser, pelo grande apoio durante todas as fases das análises geocronológicas.

Aos laboratórios de química e ICP e Fluorescência de Raios X, especialmente à Marinês Lopes da Silva, Sandra Andrade e Paulo Ernesto Mori, pelo grande auxílio na obtenção de dados geoquímicos.

Agradeço também a Ana Paula Cabanal, Magali Poli F. Rizzo (secretárias da pós graduação) pelos inúmeros favores.

Finalmente agradeço à CAPES pela bolsa de mestrado. 


\subsection{INTRODUÇÃO}

\subsection{Definição de propósitos:}

Este trabalho iniciou-se em 2003, tendo como objetivo principal, o estudo geocronológico da Formação Betara, área anteriormente pesquisada (em parte) pela autora, quando da disciplina de Mapeamento de Graduação (UFPR). A região do Betara inclui terrenos granito-gnáissicos (Núcleo Betara) e sequências metavulcanossedimentares de baixo à médio grau metamórfico (Formação Betara). Esses terrenos ocorrem em meio às sequências metavulcanossedimentares da Formação Votuverava, balizadas à sul-sudeste pela Zona de Cisalhamentos Lancinha. O estudo geocronológico concentrou-se em rochas metabásicas, reconhecidas nos perfis de campo realizados, em meio às sequências metavulcanossedimentares, bem como em meio aos terrenos proto à miloníticos de natureza sienogranítica. Na tentativa de obter-se dados relativos à época de formação (terrenos granito-gnáissicos) e deposição (sequências metavulcanossedimentares), optou-se principalmente pelo método U-Pb em zircões. A concentração de zircões exigiu grandes quantidades de amostras, e nem sempre foi realizada com sucesso, uma vez que tais minerais são raros em litotipos metabásicos, contando ainda com a dificuldade de seu reconhecimento em lupa (hábitos raramente prismáticos).

Foi preocupação maior deste trabalho, caracterizar geocronológicamente estes diferentes terrenos, numa tentativa de melhor compreender a evolução tectônica da região do Betara. O esboço geológico e os perfis apresentados integram as informações geocronológicas, que contam adicionalmente com estudos estruturais, petrográficos e geoquímicos. 


\section{2 Área Investigada}

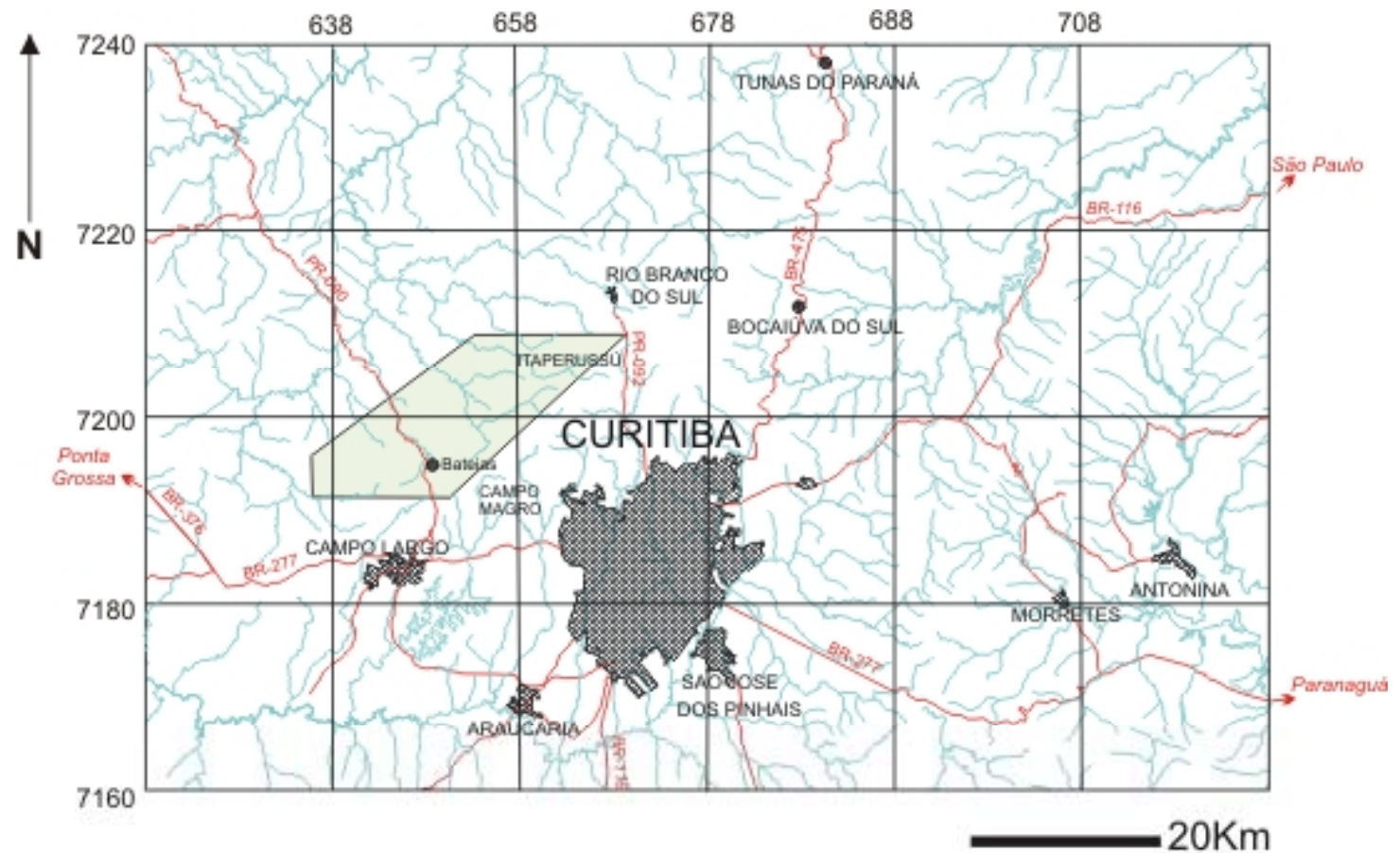

$\sim$ Estradas asfaltadas $\square$ Estradas não pavimentadas

$\square$ Rios Cidades $\neg$ Área de estudo 
Figura 1.1: Localização e acesso à área de estudo

A área de estudo (região do Betara) localiza-se a nordeste da cidade de Curitiba. O acesso principal à região é realizado através da Rodovia dos Minérios (PR-092) rumo à cidade de Rio Branco do Sul, distante cerca de $20 \mathrm{~km}$ a norte de Curitiba (Figura 1.1). De Rio Branco do Sul o acesso é realizado através de estrada vicinal (rumo SW), que liga esta cidade às localidades de Itaperussu, Pombas, Meia Lua dos Freitas, Meia Lua da Conceição e Conceição e também à cidade de Bateias. A partir desta existem alguns acessos secundários que cortam grande parte da área selecionada para estudo.

Outro importante acesso pode ser realizado através da BR-277 (Curitiba-Campo Largo) e daí seguimos para norte através de estradas secundárias, atingindo as localidades de Itambé e de Rio Açungui.

\subsection{Evolução dos Conhecimentos}

\subsubsection{Um Breve Histórico dos Trabalhos Realizados no pré-Cambriano Paranaense -} Trabalhos Pioneiros: Fase Histórica

Os trabalhos de cunho geológico do pré-Cambriano paranaense foram motivados desde cedo, devido a ocorrência de importantes jazimentos minerais na região (chumbo, prata, ouro, cobre, cassiterita, wollastonita, schellita, mármore, fluorita, barita, calcita, esfalerita e rochas ornamentais). Durante a segunda metade do século XIX até o final da década de 40, os trabalhos realizados envolveram principalmente o reconhecimento geológico desses terrenos. Neste período surgem os primeiros mapas regionais e a denominação de "Série Assunguy" para as rochas metassedimentares do leste paranaense. Destacam- se neste período as pesquisas realizadas por Derby (1878), Oliveira (1927), Carvalho Pinto (1937), Oliveira e Leonardos (1943) e Maack (1947).

As pesquisas realizadas por Derby (1878) caracterizam a existência de dois pacotes rochosos distintos que denominou de séries "Não Cristalofilianas" (Arqueano) e "Cristalofilianas" (Cambriano ao Siluriano Inferior).

O primeiro mapa geológico regional (escala 1:1.000.000) foi apresentado por Oliveira (1927), que denominou as rochas metassedimentares do primeiro planalto 
paranaense de "Série Assunguy" representada por xistos argilosos, quartzitos e calcários, de provável idade Ordoviciana.

Carvalho e Pinto (1937) em seu "Reconhecimento Geológico da Série Assunguy", sugerem uma tectônica de esforços tangenciais de direção aproximada norte-sul, responsáveis pelas estruturas antiformais e sinformais presentes. Fazem ainda referência a micaxistos que julgam pertencer a terrenos mais antigos que a "Série Assunguy", bem como a granitos intrusivos nestas seqüências metassedimentares.

Oliveira e Leonardos (1943) sugerem para o que denominaram de Série Açungui (xistos, filitos e metamargas) uma gênese relacionada a ambiente de mar relativamente profundo. Atribuem idade Algonquiana (pré-Cambriana) para esta série. Maack (1947) reestudando a "Série Açungui", propõe para a mesma idade Eo-Algonquiana. Engloba nesta série tanto rochas metassedimentares epimetamóficas (filitos, mica-xistos, cloritaxistos, talco-xistos, extensas lentes de calcários e calcários dolomíticos, camadas esparsas de quartzitos puros e quartzitos com minério de ferro sedimentar), como gnaisses de injeção, que julga mais recentes.

\subsubsection{A Formação Setuva e o Complexo Pré-Setuva: Relações com o Grupo Açungui}

A partir da década de 50, inicia- se uma nova fase, na qual os estudos envolvendo relações estratigráficas, tectônicas e mapeamentos geológicos (locais e regionais) são priorizados. A partir deste período, várias foram as propostas estratigráficas para o préCambriano paranaense, incluindo a adição ou retirada de formações, modificações no empilhamento, áreas de ocorrência, atingindo mais de quarenta colunas geológicas sugeridas, sintetizadas em Fiori (1990) e Fassbinder (1996).

A Formação Setuva foi descrita pela primeira vez por Bigarella e Salamuni (1956), e retomada pelos mesmos autores em 1958. Foi individualizada como formação basal do Grupo Açungui, sendo sua extensão nesta época restrita ao Anticlinal do Setuva. Esta formação é representada principalmente por sericita quartzitos, filitos e gnaisses, aflorantes no Morro do Setuva. Descrevem ainda a Formação Capiru, representada por uma seqüência de metacalcários sobrejacente à Formação Setuva. Bigarella e Salamuni (1967) julgando inadequado a utilização do termo Série Açungui, propõem a denominação de Grupo Açungui. 
Marini et al.(1967) concordam com a proposição de Bigarella e Salamuni (1956), incluindo a Formação Setuva na porção basal do Grupo Açungui, referindo-se a quatro locais de ocorrência desta formação (Anticlinal do Setuva, Morro Betara e duas a nordeste de Tunas/ região da antiforma de Anta Gorda). Fuck et al. (1969) acrescentaram ao novo mapa geológico da parte pré- Devoniana do Estado do Paraná as ocorrências da Formação Setuva representada por rochas gnáissicas e micaxistos.

Uma nova subdivisão estratigráfica para o Grupo Açungui foi proposta por Marini (1970) que inclui a Formação Setuva no embasamento, com base em diferenças metamórficas e estruturais. Menciona a existência de padrões geológicos distintos, dentre os quais destaca a discordância angular, brusca mudança do grau metamórfico e diferenças nas direções de eixos de dobras existentes entre as rochas das Formações Setuva e Capiru.

Ebert (1971), baseado em dados metamórficos de amostras coletadas ao longo da Estrada da Ribeira, no Anticlinal do Setuva, restringe a Formação Setuva aos xistos e quartzitos, posicionando-a na base do Grupo Açungui. O autor engloba as rochas gnáissicas que denomina de Grupo Pré-Setuva, subdividindo- as em uma seqüência de paragnaisses e um complexo granítico intrusivo,intensamente milonitizado. A tendência geral dos trabalhos mais recentes seguem a proposta de Ebert (1971).

Schöll et al. (1980) também restringem a Formação Setuva aos xistos e filitos, porém retiram a mesma do Grupo Açungui, baseados no hiato metamórfico-estrutural já constatado por Marini (1970). Esses autores também separam os terrenos gnáissicos no denominado Complexo pré-Setuva, contendo uma unidade superior de paragnaisses e uma inferior de migmatitos e dos granitos de anatexia parcialmente milonitizados.

Schöll (1981) menciona diferenças metamórficas nas unidades que compõem o Núcleo do Setuva. Caracteriza uma primeira unidade com metamorfismo de grau mais alto, que atinge o fácies anfibolito (zona da estaurolita), com retrometamorfismo no fácies xisto verde (zona da clorita),e uma segunda unidade onde o metamorfismo é do fácies xisto verde (zona da clorita).

Dentre os trabalhos de cartografia geológica, síntese e interpretação regional destacam-se: Comissão da Carta Geológica do Paraná (1969); Projeto Ribeira(1981); Projeto Sudeste do Estado de São Paulo(1972); Projeto Leste do Paraná(1977); Projeto 
Integração e Detalhe Geológico do Vale do Ribeira(1981); e no âmbito das Jazidas Canoas e Perau o de Daitx (1996).

\subsubsection{Complexos Pré Setuva, Setuva e os Núcleos Betara e Tigre}

Popp et al. (1979), em estudos realizados na região do Núcleo Betara, elevam a Formação Setuva à categoria de Grupo, reconhecendo a Formação Meia Lua, representada por paragnaisses, xistos, quartzitos e granitóides tectonicamente imbricados e a Formação Betara, que inclui rochas metavulcânicas (metatraquitos), metassedimentos terrígenos e clasto-químicos (metargilitos, mármores e quartzitos).

Piekarz (1981 e 1984) adota a denominação de Formação Perau para o conjunto de rochas descritas como Seqüência Perau (Fritzons Jr. et al. 1982), posicionando-a estratigraficamente no Grupo Setuva (Estado do Paraná). Engloba este conjunto de rochas

juntamente com a Formação Água Clara descrita por Marini (1970), como Formação préSetuva. Adota tal denominação para as unidades superior e inferior presentes no Núcleo Betara.

Os trabalhos de mapeamento geológico realizados pela CPRM (1981) no âmbito destes Núcleos consideram as rochas gnáissicas (orto e paraderivadas) aflorantes na antiforma do Setuva, Anticlinório Anta Gorda e no Alto Estrutural da Região do Ribeirão Meia Lua e do Rio Capivara como membro basal do Grupo Setuva.

Hasui et al. (1984) denominam de Complexo Setuva a um extenso e contínuo conjunto litológico distribuído na região do "Granito Três Córregos" constituído de gnaisses, xistos, quartzitos, rochas carbonáticas, cálcio- silicáticas e rochas anfibolíticas. Atribuem características semelhantes a uma faixa que ocorre junto ao "Granito Cunhaporanga", sugerindo a continuidade do "Complexo Setuva" para oeste. Como processo tectônico marcante na história geológica regional, os autores caracterizam uma fase de cisalhamento dúctil de baixo ângulo que no contexto regional é vinculada à história tardi-arqueana do Cinturão Móvel Costeiro.

Fiori et al. (1987a) descrevem uma intensa deformação milonítica impressa nas rochas do Complexo pré-Setuva associadas à Falha do Setuva. Observa ainda que a intensidade dessa deformação é decrescente em direção ao núcleo da antiforma. Fiori et al. (1987b, 1987c) não concordam com a denominação extensiva de Grupo Setuva aos xistos 
que ocorrem nas bordas da antiforma, sugerindo que os mesmos representem um tectonofácies dos terrenos gnáissico- migmatíticos.

Salamuni (1991) identifica no Núcleo Betara rochas metavulcânicas (metatraquitos), metassedimentos terrígenos e clasto-químicos (metargilitos, mármores e quartzitos) atribuídos à Formação Betara, distinguindo-os dos terrenos do embasamento (Complexo Meia Lua), representado principalmente por paragnaisses, xistos, quartzitos e rochas granitóides com forte embricamento tectônico.

Salamuni et al. (1993), com base em estudos estruturais, sugerem para o Núcleo Betara um regime tectônico associado a cavalgamentos seguido de transcorrências e dobramentos generalizados. Sua arquitetura estaria ligada a sistemas tipo "duplex" gerando uma tectono-estratigrafia com embricamentos e repetições de camadas similarmente ao observado por Fiori (1990) para as seqüências do Grupo Açungui. Mantém a hierarquia de Formação Betara e Complexo Meia Lua e sugerem a presença de uma deformação pretérita $\mathrm{F}_{\mathrm{N}}-1$.

Althoff e Fiori (1991) apontam a existência de três domínios distintos na porção ocidental da Antiforma do Setuva: O Domínio I, composto por granito- gnaisses, gnaisses bandados, quartzitos e xistos; o Domínio II, composto por xistos e quartzitos; e o Domínio III, constituído por xistos, quartzitos, mármores e rochas metassedimentares pouco deformadas. Os autores caracterizam uma paragênese indicativa de condições metamórficas de baixo a médio grau (fácies xisto verde à anfibolito) no núcleo da Antiforma do Setuva, não havendo indícios do grau alto (possível embasamento regional).

Monteiro et al. (1994) sugerem que as rochas granitóides, dioríticas e gabros associados à Formação Perau, distribuídas no Núcleo Betara, associem- se aos estágios de fechamento da bacia. Caracterizam esforços compressivos com direção NW-SE, e intenso transporte tectônico para SE, com desenvolvimento de uma foliação S1 e uma foliação milonítica S2. Para Martin et al.. (1994), as rochas xistosas aflorantes no Núcleo Betara representam uma tectono-fácies dos granitóides e corpos metadioríticos-metagábricos, ocorrendo nas zonas de maior deformação. 
Silva et al. (1998) interpretam as rochas gnáissicas do Núcleo Setuva como parte integrante do Complexo Atuba (definido por Siga Júnior et al. 1995), e as rochas metassedimentares, que ocorrem na borda desta estrutura, como um fácies intensamente deformado da Formação Capiru, similarmente ao admitido por Fiori (1987b e 2003). Yamato (1999) também relaciona as rochas gnáissicas deste núcleo ao Complexo Atuba, incluindo, porém os sericita-xistos, quartzitos finos e metacalcários dolomíticos miloníticos (porção externa do núcleo) na Formação Setuva.

Kaulfuss (2001) observa que o padrão geocronológico e estrutural das rochas pertencentes ao Núcleo Setuva se mostra bastante similar ao descrito para o Complexo Atuba, distinguindo deste contexto os Núcleos do Tigre e Betara. Caracteriza a predominância, nos três núcleos estudados (Betara, Tigre e Setuva), de terrenos graníticos lato-sensu de natureza sienogranítica, monzogranítica, granodiorítica, quartzo-monzonítica e quartzo-monzodiorítica. Menciona que estes terrenos se encontram afetados heterogeneamente por importantes sistemas de cisalhamento tanto de baixo como de alto ângulo. $\mathrm{O}$ autor descreve ocorrências de sienogranitos no âmbito dos Núcleos Betara e Tigre com idades próximas de 1750 Ma. Essas rochas denotam caráter bem evoluído, indicativos de granitos do tipo A (anorogênicos), ou seja, relacionados a processos distensivos. Braga et al.(2002) consideram o Núcleo Betara como uma janela tectônica. Concordam com a subdivisão do mesmo em Formação Betara (topo) e Complexo Meia Lua (base). Identificam dois eventos metamórficos, o primeiro do fácies anfibolito (associado provavelmente ao Sistema de Cavalgamentos Açungui) e o segundo do fácies xisto verde, com o desenvolvimento de micas brancas e epidoto.

\subsection{Contexto Geocronológico da Faixa de Dobramentos Apiaí}

O estudo geocronológico das rochas gnáissico-migmatíticas e graníticas protomiloníticas à miloníticas dos núcleos de embasamento, bem como das seqüências metavulcanossedimentares da Faixa de Dobramentos Apiaí, revela um cenário tectônico complexo e policíclico. Grande parte das metodologias isotópicas utilizadas nestes terrenos referem-se aos sistemas $\mathrm{Rb}-\mathrm{Sr}$ e $\mathrm{K}$ - Ar em minerais. Somente na última década foram realizadas determinações radiométricas, utilizando-se dos métodos $\mathrm{U}-\mathrm{Pb}$ (zircões) e $\mathrm{Sm}-\mathrm{Nd}$ em rocha total. 
Batolla Jr. et al. (1977) utilizaram-se do método Rb-Sr em diferentes litotipos, tais como xistos, filitos, gnaisses e neossomas de migmatitos do Grupo Setuva. Tais dados mostraram-se dispersos em diagrama isocrônico e quando recalculados por Teixeira (1982), permitiram o traçado de três alinhamentos distintos com idades de 1420 +- $120 \mathrm{Ma}$ (ri= 0,766 +- 0,0030), 1212 +- $55 \mathrm{Ma}(\mathrm{ri}=0,7112+$ + 0,0024) e 586 +- $8 \mathrm{Ma}(\mathrm{ri}=0,7434$ +0,0006). O primeiro valor foi associado o evento metamórfico que afetou as rochas do Grupo Setuva, o segundo foi relacionado ao metamorfismo impresso nos xistos da Formação Perau e o terceiro foi considerado como representante de um episódio rehomogeinizador, associado ao metamorfismo de baixo grau impresso nessas seqüências.

Daitx et al. (1990) apresentam uma idade isocrônica Rb-Sr de $850^{+}$. 85 Ma.(ri = 0,705) para o Gabro Apiaí, interpretada como relativa à época de intrusão deste corpo na seqüência Iporanga. Análise K-Ar (biotitas) deste corpo acusaram valor de $675^{+} .45 \mathrm{Ma}$. (Silva et al., 1981) interpretado como relativo ao resfriamento destas rochas a temperaturas inferiores à $.300^{\circ} \mathrm{C}$. Dados K-Ar adicionais encontram-se reportados em Teixeira (1982), e referem-se a rochas gnáissicas e filíticas pertencentes à Formação Setuva, cujos valores distribuem-se entre 780 e 540 Ma., interpretados como idades mínimas relacionadas ao resfriamento destas seqüências durante o evento geodinâmico Brasiliano.

Campanha (1991) apresenta uma isócrona Rb-Sr para os metabasitos da Formação Perau (Seqüência Rio das Pedras) com idade de 1745 +- 14 Ma (ri=0,7089 +- 0,0001). Este diagrama alinha somente quatro pontos analíticos, três dos quais bastante próximos entre si (razões $\mathrm{Rb} / \mathrm{Sr}$ entre 0,3 e 0,4 ), estando o quarto ponto analítico posicionado próximo à origem, definindo a relação inicial. Trata-se, portanto, de uma idade que deve ser encarada com ressalvas, necessitando de dados adicionais que confirmem tal valor. $\mathrm{O}$ mesmo autor apresenta estudos isotópicos $\mathrm{Rb}$-Sr relativos aos xistos da Formação Setuva (Seqüência Turvo Areado em Barra do Turvo), com idades isocrônicas de 728 +- $26 \mathrm{Ma}$ (ri= 0,7089 +0,0008) e ardósias da Formação Perau (Seqüência Rio das Pedras, Estrada IporangaCaverna do Diabo) com idades isocrônicas de $765+-35 \mathrm{Ma}(\mathrm{ri}=0,7316+-0,0005)$. Os valores isocrônicos foram interpretados pelo autor como relativos a épocas de metamorfismo que afetaram essas seqüências. Acrescente-se que os pontos analíticos mostraram-se relativamente dispersos nos diagramas isocrônicos, conferindo elevados erros às idades, bem como valores elevados de MSWD. 
Valores relacionadas ao Mesoproterozóico (1500-1400 Ma. e 1300- 1100 Ma.) foram obtidos através da metodologia Pb-Pb por Tassinari et al. (1990); JICA/ MMAJ $(1982,1983)$ e Daitx (1996) em galenas e jazimentos de chumbo do Vale do Ribeira, principalmente quando utilizados os modelos de Cumming e Richards (1975). Tais intervalos de idade levaram os autores a distinguir dois tipos de jazimentos: Tipo Perau e Canoas (idades mais antigas) e Tipo Panelas (idades mais jovens).

Nogueira (1990) obtém para galenas do depósito aurífero do Piririca, através do método $\mathrm{Pb}-\mathrm{Pb}$, idades entre 1300 e $1200 \mathrm{Ma}$, similares às observadas para depósitos mais jovens (Tipo Panelas).

Valores $\mathrm{K}$-Ar, bem como isócronas $\mathrm{Rb}-\mathrm{Sr}$ em rocha total relacionadas ao Neoproterozóico (765-600 M.a.), foram obtidas, notadamente em xistos e metabásicas da Seqüência Perau, por Maniesi (1997), Campanha (1991) e Daitx (1996).

Maniesi (1997) apresenta idade K- Ar em plagioclásio de rocha metabásica na região de Adrianópolis, de 1456 +- 25 Ma. Menciona que estas rochas metabásicas apresentam cristais preservados do efeito metamórfico regional e que as transformações existentes ocorrem exclusivamente ao longo de fraturas.

Daitx (1996) apresenta isócronas Rb-Sr (rocha total) de 'metafelsitos' da seqüência superior da Formação Perau com idade de $1283+28$ Ma. (ri= 0,7079).

Kaulfuss (2001), em estudo geocronológico pioneiro nas regiões dos Núcleos Betara e Tigre, reconhece, além das idades obtidas nos granitóides alcalinos (1750 Ma.), um caráter policíclico nos demais litotipos dos Núcleos (monzogranitos, granodioritos, quartzo monzonitos e quartzo-monzodioritos), com heranças em zircões relativas ao Arqueano (3100 Ma.) e Paleoproterozóico (2100 à 2200 Ma.). A tectônica neoproterozóica é caracterizada tanto em sobrecrescimentos relativos a bordas de zircões, como através dos métodos K-Ar e Ar-Ar com idades que se aproximam de $600 \mathrm{Ma}$. O autor destaca que a maioria dessas rochas teve seus protólitos crustais diferenciados do manto superior durante o Arqueano (idades Sm-Nd).

Kaulfuss (2001) e Siga Jr et al. (2003), utilizando-se dos métodos U- Pb (zircão), $\mathrm{Pb}-\mathrm{Pb}, \mathrm{K}-\mathrm{Ar} / \mathrm{Ar}-\mathrm{Ar}$ e Sm-Nd, caracterizaram para rochas gnáissico migmatíticas da porção sul do Núcleo Setuva e granitos do setor centro-norte, padrão isotópico complexo e policíclico. Os autores evidenciam a presença de heranças isotópicas relativas ao Arqueano 
e Paleoproterozóico em rochas intensamente retrabalhadas durante o Neoproterozóico ( 600 Ma.).

Cury et al. (2002) estendem a área de ocorrência das rochas de natureza sienogranítica, com idades próximas de $1750 \mathrm{Ma}$ (relacionadas ao período Estateriano), às proximidades do Núcleo do Cerne. Os autores ainda destacam que a derivação do manto superior dos protolitos crustais dessas rochas parece relacionar-se ao Arqueano, conforme idade modelo (Sm-Nd - TDM) de 2840 Ma. (sienogranito milonítico do Núcleo Betara). Tal valor, acoplado à época de formação ( 1750 Ma.), reflete o longo período de residência crustal, também caracterizado através do valor de $\quad$ Nd $(-8,0)$; calculado para $1750 \mathrm{Ma}$.

Cury et al. (2002), sugerem ainda que parte da seqüência metavulcanossedimentar, admitida por diversos autores como Complexo Perau (no Núcleo do Tigre) e Formação Meia Lua (no Núcleo Betara), possa representar uma sedimentação em bacias (tipo rift), desenvolvidas nessa época ( 1750 Ma.).

Destacam ainda a importância desse evento tafrogenético no âmbito do sul e sudeste brasileiro, envolvendo a colocação de granitos alcalinos possivelmente com sedimentação e magmatismo básico associados (Formações Betara e Perau). A importância dessa tectônica distensiva já havia sido destacada por Brito Neves et al. (1995), sendo reconhecida no Brasil, na Província Borborema, Sistema Espinhaço, Grupo São João Del Rey, Província Tocantins e Faixa Ribeira. Estas idades em torno de 1,75 Ga, reconhecidas principalmente na porção centro-oriental do continente Sul- Americano, devem representar importantes cicatrizes associadas à ruptura do Supercontinente Atlântica (Rogers 1996) do Paleoproterozóico.

Weber et al. (2003) obteve para rochas metabásicas da Formação Água Clara idades U-Pb entre 1590-1470 Ma relacionadas à cristalização dos zircões e conseqüente formação desses litotipos. Os estudos de catodoluminescência realizados nos zircões sugerem a presença de núcleos mesoproterozóicos e zonas de sobrecrescimento com amplitudes variáveis com idades (intercepto inferior de diagramas concórdia e valores Ar-Ar) do intervalo de 600-580 Ma.

Basei et al. (2003) apresentam idades U-Pb em zircão próximas de $1500 \mathrm{Ma}$. para rochas metabásicas associadas às Formações Votuverava e Perau. Os autores indicam 
caráter toleítico subalcalino para essas rochas metabásicas (sugestivas de ambientes distencionais). Representam possíveis sills ou diques, sugerindo que valores próximos a 1500Ma. sejam mínimos de sedimentação dessas bacias, possivelmente bem mais próximos ao desenvolvimento das mesmas.

No âmbito da Formação Itaiacoca, Reis Neto (1994) realizou estudos geocronológicos em rochas metavulcânicas, envolvendo as Formações Abapã, Bairro dos Campos e Água Clara, utilizando- se de isócronas de $\mathrm{Rb}-\mathrm{Sr}, \mathrm{Pb}-\mathrm{Pb}$, e $\mathrm{Sm}-\mathrm{Nd}$, em rocha total e minerais. Reis Neto (1994) obteve valores isotópicos relativos ao final do Mesoproterozóico (1250-1100 Ma.) interpretados como representativos da época de sedimentação e vulcanismo associado.

Siga Júnior et al. (2003 a; 2003 b e 2006) sugerem para a sequência Itaiacoca a presença de dois conjuntos litológicos temporalmente distintos, o primeiro representando principalmente por metacalcários dolomíticos e metamargas com idades mínimas de deposição relacionadas ao final do mesoproterozóico/ início do neopoterozóico (1030 - 908 Ma.). O segundo conjunto é representando principalmente por metarcóseos, metavulcânicas, metaconglomerados e metapelitos com idades de deposição relacionadas ao neoproterozóico (645-628 Ma.). Sugerem similarmente a Soares (1987), que o termo Formação itaiacoca represente o conjunto de metacalcários dolomíticos, originalmente proposto por Almeida (1957), e que se utilize para o conjunto de metarcóseos/metavulcânicas/filitos/conglomerados do termo Formação Abapã (Trein et al.1985). Destacam ainda que as idades de formação destas rochas vulcânicas (645-628 Ma.) são bastante próximas às observadas para os batólitos graníticos Três Córregos e Cunhaporanga (650-600 Ma. Prazeres Filho et al. 2003 e Prazeres Filho, 2005).

Vale mencionar para fins de correlações que valores U-Pb (zircão) relacionados ao Mesoproterozóico (1395 ${ }^{+}$.10 M.a.) foram obtidos por Juliani et al. (2000) em metaandesitos da Formação Pedra Preta, do Grupo Serra do Itaberaba. Da mesma maneira idades U- $\mathrm{Pb}$ (zircão) relativas ao Neoproterozóico (630-610 M.a.) foram obtidas para rochas do Grupo São Roque e Formação Iporanga por Hackspacher (2000), interpretadas como relacionadas à sedimentação desta seqüência. Dados obtidos para a Formação Iporanga referem-se ainda a Salazar et al. (2004) e Campanha et al. (2004). 
Valores isotópicos mais jovens no âmbito da Faixa Apiaí referem-se à colocação dos maciços graníticos tipo Cerne, com idades do intervalo entre 580- 560 Ma. (Cury 2003) e desenvolvimento de bacias sedimentares tipo Castro com idades U-Pb (zircão) de rochas vulcânicas próximas de 560 M.a. (Cordani et al. 1999).

O quadro geológico-geocronológico apresentado abaixo revela a grande complexidade envolvendo o empilhamento litoestratigráfico das seqüências metavulcanossedimentares da Faixa de Dobramentos Apiaí, para a qual dezenas de colunas foram propostas, com idades de sedimentação que se distribuem desde o final do Paleopreterozóico ao Neoproterozóico.

O contexto geocronológico apresentado modifica significativamente muitas das proposições estratigráficas até o momento conhecidas. Algumas denominações como Grupos Açungui e Setuva, ou mesmo Faixa Apiaí deixam de ter significado, uma vez que tratam-se de seqüências temporalmente distintas colocadas lado a lado por importantes sistemas de cisalhamentos. A tectônica neoproterozóica parece ser a responsável pela aloctonia destes terrenos e colocação lado a lado dos mesmos. O quadro sintetiza a estratigrafia em diferentes compartimentos que compõem a Faixa Apiaí de acordo com as datações realizadas nos trabalhos de cunho geocronológico e/ou estratigráfico mais atuais.

\begin{tabular}{|c|l|l|}
\hline Período & Idades (Ma) & Unidade \\
\hline $\begin{array}{c}\text { Neoproterozóico } \\
\text { (superior) }\end{array}$ & $\sim 640-600$ & $\begin{array}{l}\text { Sequências Lajeado, Iporanga e Abapã } \\
\text { (metarcóseos/metavulcânicas, } \\
\text { metaconglomerados, metapelitos) }\end{array}$ \\
\hline $\begin{array}{c}\text { Neoproterozóico } \\
\text { (inferior) }\end{array}$ & $1100-900$ & $\begin{array}{l}\text { Sequência Itaiacoca } \\
\text { (metacalcários dolomíticos } \\
\text { metamargas) }\end{array}$ \\
\hline $\begin{array}{c}\text { Mesoproterozóico } \\
\text { Paleoproterozóico } \\
\text { (Superior }\end{array}$ & $1750-1700-1400$ & $\begin{array}{l}\text { Sequências Betara, Votuverava, Água } \\
\text { Clara, Perau e Grupo Serra do Itaberaba }\end{array}$ \\
\hline $\begin{array}{l}\text { Sequências Betara Inferior (?) e Perau } \\
\text { Inferior(?) } \\
\text { (Sienogranitos e metabásicas dos } \\
\text { núcleos Betara e Tigre) }\end{array}$ \\
\hline
\end{tabular}




\subsection{MÉTODOS DE TRABALHO}

Serão apresentadas aqui as metodologias utilizadas para a confecção deste trabalho. Tal abordagem será desenvolvida em duas partes, abrangendo inicialmente os estudos geológicos convencionais e à seguir os métodos geocronológicos que constituem a base do presente trabalho.

\subsection{Estudos Geológicos Convencionais}

As sucessivas etapas pelas quais passou esta pesquisa podem ser assim resumidas:

- Análise bibliográfica, com a finalidade de selecionar publicações de interesse à região estudada.

- Viagem de campo, visando o reconhecimento das principais unidades geológicas da Região do Betara e arredores. Foram utilizadas nesta etapa os mapas geológicos disponíveis e como base topográfica as folhas plani-altimétricas do IBGE e COMEC, escalas 1:50.000 e 1: 100.000 .

- Análise de imagens de satélite na escala 1:100.000. 
- Trabalhos de campo e confecção de perfis geológicos tendo por objetivos a caracterização das diferentes unidades de mapeamento, bem como de efetuar coleta de amostras para análises petrográficas, geoquímicas e principalmente geocronológicas. Os trabalhos de campo envolveram o estudo de cerca de 80 afloramentos

- Trabalhos de laboratório, em que foram realizadas as observações de lâminas delgadas ao microscópio com a finalidade de promover a seleção e a preparação de amostras, principalmente para estudos geoquímicos e determinações radiométricas.

- Confecção de um esboço geológico-geotectônico da região do Betara em escala 1:100.000.

\subsection{Estudos Geoquímicos}

Foram realizadas análises geoquímicas em rocha total de seis amostras de litotipos metabásicos associadas à sequência do Betara. Para tais análises foram escolhidos exemplares com o menor ou nenhum grau de alteração intempérica visível. Os procedimentos realizados foram os seguintes:

- quebra manual das amostras de modo a eliminar possíveis vestígios de alteração intempérica;

- Redução através de quebra manual em pedaços de aproximadamente 5 centímetros;

- Britagem para redução da rocha em pedaços inferiores à $5 \mathrm{~cm}$ em britador de mandíbulas (aço);

- Quarteamento e moagem do material utilizando-se de moinho de bolas.

O material resultante, em granulometria inferior a 250 mesh, foi encaminhado para o Laboratório de Fluorescência de Raios X do GMG IGc-USP para análise de elementos maiores e menores $\left(\mathrm{SiO}_{2}, \mathrm{Al}_{2} \mathrm{O}_{3}, \mathrm{Fe}_{2} \mathrm{O}_{3}, \mathrm{MgO}, \mathrm{CaO}, \mathrm{Na}_{2} \mathrm{O}, \mathrm{K}_{2} \mathrm{O}, \mathrm{P}_{2} \mathrm{O}_{5}, \mathrm{MnO}\right.$ e $\left.\mathrm{TiO}_{2}\right)$ em pastilhas fundidas, e traços ( $\mathrm{Ba}, \mathrm{Be}, \mathrm{Cl}, \mathrm{Co}, \mathrm{Cr}, \mathrm{Cu}, \mathrm{F}, \mathrm{Ga}, \mathrm{Nb}, \mathrm{Ni}, \mathrm{Pb}, \mathrm{Rb}, \mathrm{S}, \mathrm{Sc}, \mathrm{Sr}, \mathrm{Th}, \mathrm{U}$, V, Y, Zn e Zr) em pastilhas prensadas. Os elementos terras raras (ETR) (La, Ce, Nd, Sm, Eu, Gd, Dy, Ho, Er, Yb, e Lu) foram dosados no Laboratório deQuímica e ICP do GMGIGc-USP. Para o processamento destes dados foram utilizados os seguintes softwares: Minpet 2,0, Excel 98 e Corel Draw versões 11 e 12. 


\subsection{Metodologias Isotópicas Utilizadas}

Grande parte dos terrenos pré-Cambrianos do território brasileiro são constituídos por seqüências metavulcanossedimentares de baixo a médio grau metamórfico, cujas idades relativas ao vulcanismo/ sedimentação são bastante imprecisas, ou mesmo desconhecidas.

De um modo geral, essas seqüências envolvem sedimentação variada (termos pelíticos, psamíticos e psefíticos), vulcanismo associado de diferentes naturezas (ácida, intermediária e básica) além de metamorfismo superimposto.

As metodologias isotópicas hoje disponíveis, notadamente U-Pb, ${ }^{40} \mathrm{Ar}-{ }^{39} \mathrm{Ar}$ e $\mathrm{Sm}-\mathrm{Nd}$ acopladas ao refinamento analítico, função de salas super limpas, envolvendo filtros absolutos, reagentes e spikes super puros e equipamentos de grande definição (balanças, lupas espectrômetros), permitem a análise de alguns cristais, ou mesmo de um único cristal de certos minerais (zircão, badeleíta, titanita, monazita, anfibólio, micas, plagioclásio, etc.). Tais técnicas isotópicas têm possibilitado a obtenção de idades precisas relacionadas ao vulcanismo/ deposição e metamorfismo de seqüências metavulcanossedimentares.

A possibilidade de se analisar poucos, ou mesmo um único cristal de zircão através dos métodos convencionais, ou mesmo utilizando-se de técnicas como o SHRIMP, ICPMS, acoplados ao estudo de catodoluminescência, tem permitido a datação U-Pb de rochas onde esse mineral (zircão) é bastante escasso, a exemplo de seqüências metabásicas.

Outras metodologias, não menos importantes, referem-se aos métodos $\mathrm{K}-\mathrm{Ar} / \mathrm{Ar}-\mathrm{Ar}$, de grande valia, quando aplicadas principalmente a anfibólios, micas e plagioclásios, fornecendo valores relacionados ao resfriamento das rochas (isotermas de $500^{\circ} \mathrm{C}$ e $300^{\circ}$ C), podendo, no caso de seqüências vulcânicas, ser bastante próximos da época de deposição (minerais primários que não atingiram a temperatura de escape do gás Ar).

Análises Sm-Nd (TDM) em rocha total, por outro lado, permitem a obtenção de idades relacionadas à épocas de derivação do manto de seus protólitos crustais.

Os índices $\varepsilon_{\mathrm{Nd}}$ e $\varepsilon_{\mathrm{Sr}}$ são de grande importância na gênese de rochas, permitindo a obtenção de informações relativas ao ambiente gerador (manto, crosta superior e crosta inferior) das rochas.

Análises petrográficas e geoquímicas dos termos vulcânicos devem preceder as análises isotópicas e são de fundamental importância à caracterização genética (ambientes distensivos/compressivos). 
No âmbito da Faixa de Dobramentos Apiaí, os estudos isotópicos, acoplados a dados petrogenéticos, têm modificado significativamente o quadro tectônico até então conhecido.

\subsubsection{Metodologia Isotópica U-Pb (zircão)}

$\mathrm{O}$ urânio possui dois isótopos $\left({ }^{235} \mathrm{U}\right.$ e $\left.{ }^{238} \mathrm{U}\right)$ responsáveis pela origem de duas séries de desintegrações radioativas, produzindo respectivamente, como produtos finais, os isótopos de chumbo ${ }^{207} \mathrm{~Pb}$ e ${ }^{206} \mathrm{~Pb}$. A utilização desses cronômetros para a determinação de idades de minerais e rochas prende-se às regras básicas da radioatividade, ou seja, um nuclídeo radioativo se desintegra transformando-se em outro (radiogênico). A probabilidade de o nuclídeo desintegrar-se espontaneamente por unidade de tempo é chamada de constante de desintegração $\lambda$. Cada nuclídeo possui um $\lambda$ característico relacionado à velocidade do processo.

A equação em $T$, pode ser escrita da forma:

$$
\mathrm{T}=1 / \lambda * \operatorname{Ln}\left[1+\left(\mathrm{F}-\mathrm{F}_{\mathrm{o}}\right) / \mathrm{P}\right]
$$

Onde: $\mathrm{T}=$ instante inicial (idade); $\mathrm{P}=$ quantidade de nuclídeo radioativo; $\mathrm{F}=$ quantidade do nuclídeo radiogênico total presente no sistema $\mathrm{e}, \mathrm{F}_{\mathrm{o}}=$ quantidade inicial do nuclídeo radiogênico.

Os resultados obtidos terão significado geológico somente se algumas premissas tiverem sido respeitadas:

- a correção do $\mathrm{Pb}$ inicial deve ser adequada, dentro dos parâmetros de precisão desejados;

- $\quad$ o equilíbrio radioativo deve ter sido mantido (o radônio é um gás nobre que aparece nas duas séries de decaimento do $U$ com meia vida de alguns dias, e não deve escapar do sistema);

- $\quad$ o sistema deve permanecer sempre fechado em relação a perdas e acréscimos de $\mathrm{U}$ e/ou $\mathrm{Pb}$.

Da utilização dos diferentes pares radiométricos observa-se que, na maioria dos casos, os valores de idades obtidos em cada um deles são diferentes entre si. Este fato foi atribuído a fenômenos de metamictização, isto é, centros radioativos de $\mathrm{U}$ e Th que, atuantes num certo período de tempo, provocam a destruição gradativa do retículo cristalino dos zircões, permitindo a difusão do $\mathrm{Pb}$. 


\section{Idades Utilizadas:}

Aos trabalhos de L. H. Ahrens (1955) e posteriormente G. W. Wetherill (1956) deve-se o conceito de curva 'Concórdia' que representa o lugar geométrico dos pontos onde as idades obtidas ${ }^{206} \mathrm{~Pb}^{238} \mathrm{U}$ (eixo das ordenadas) e ${ }^{207} \mathrm{~Pb}^{235} \mathrm{U}$ (eixo das abcissas) são concordantes pelos dois cronômetros.

Desde que um ponto analítico não esteja situado sobre a curva concórdia, as idades deixam de ser as mesmas. A reta que contém os pontos discordantes recebe o nome de 'Discórdia".

O intercepto superior da Discórdia com a curva Concórdia caracteriza a época de cristalização dos zircões. Para o intercepto inferior existem interpretações que o relacionam a uma perda episódica (a perda em chumbo estaria vinculada a um episódio tectônico e, portanto o valor encontrado teria significado geológico) ou, então, a uma perda contínua (perda de chumbo por difusão contínua, não possuindo, portanto, a idade encontrada, qualquer significado geológico). Este efeito pode ser minimizado através de uma cuidadosa abrasão a ar e pirita dos zircões, eliminando zonas de borda (onde os efeitos de metamictização ou recristalização são mais intensos). Análises de zircões que compreendem mais de 2 componentes de idades (zonas de sobrecrescimentos) tendem a acrescentar grandes complexidades à interpretação (Parrish \& Noble 2003). Uma maneira alternativa de representar os dados U-Pb foi desenvolvida por Tera e Wasserburg (1972). O diagrama de Tera-Wasserburg pode ser utilizado de duas maneiras:

- $\quad$ Plotando-se os dados medidos de ${ }^{207} \mathrm{~Pb} /{ }^{206} \mathrm{~Pb}$ (eixo das ordenadas) contra os valores ${ }^{238} \mathrm{U} /{ }^{206} \mathrm{~Pb}$ (eixo das abcissas). Este diagrama é muito utilizado, quando há dificuldades em medir-se o $\mathrm{Pb}$ comum da amostra, em geral para valores muito baixos de ${ }^{204} \mathrm{~Pb}$, ou quando sua composição isotópica é pouco conhecida ou difícil de estimar. Análises de microssonda iônica para dados U-Pb utilizam-se normalmente deste diagrama.

- Alternativamente, pode-se representar o chumbo total e o chumbo comum corrigindo-se ${ }^{207} \mathrm{~Pb} /{ }^{206} \mathrm{~Pb}$ contra ${ }^{238} \mathrm{U} /{ }^{206} \mathrm{~Pb}$ de forma análoga ao diagrama Concórdia. O arranjo dos pontos em termos de discordância, herança, perda de chumbo, é análogo ao diagrama Concórdia quando o chumbo radiogênico é utilizado (Parrish \& Noble 2003). 


\section{Materiais Utilizados:}

Teoricamente todo sistema rico em urânio, ou seja, todo material que tenha urânio suficiente para permitir a formação de quantidade de chumbo radiogênico mensurável e que não incorpore quantidade de chumbo de outra origem (não produto da desintegração do elemento radioativo) é passível de ser medido.

Os zircões são os mais favoráveis, uma vez que se encontram presentes em praticamente todas as rochas (ácidas, intermediárias e básicas). Apresentam riqueza em urânio e incompatibilidade geoquímica com o chumbo, (praticamente todo o chumbo encontrado, é de origem radiogênica). Os zircões são também minerais de grande resistência aos agentes intempéricos o que permite sua utilização para datação de rochas intemperizadas e sedimentares (zircões detríticos). Denota ainda, em muitos casos, grande estabilidade às variações físico-químicas, podendo preservar idades antigas (heranças), mesmo em rochas submetidas a episódios metamórficos de grande intensidade, capazes de rejuvenescer completamente outros cronômetros radiométricos.

Estudos experimentais como de Cherniac e Watson (2000) indicam que as temperaturas de fechamento do zircão, calculadas a partir dos parâmetros de difusão,

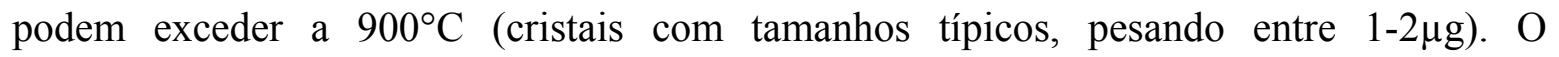
comportamento do zircão a temperaturas mais baixas, como em fases metamórficas de baixo grau e hidrotermalismo, é bastante discutido na literatura. A presença de fluidos e as características químicas do ambiente também exercem um importante papel, podendo variar a temperatura de saturação do $\mathrm{Zr}$ (Watson et al. 1983).

\section{Concentração, Purificação e Seleção de Zircões}

A quantidade de material amostrado em campo é importante e varia, em médiade $10 \mathrm{~kg}$ (rochas de natureza ácida ou intermediária) a cerca de $20 \mathrm{~kg}$ de material (rochas de natureza básica). Além disso, deve-se evitar misturas de porções do afloramento que possam ser geneticamente distintas. Não há grandes problemas com relação ao grau de alteração das rochas, uma vez que os zircões são minerais altamente resistentes ao intemperismo.

A separação e concentração seguem as seguintes etapas: 
-A amostra coletada é fragmentada manualmente em pedaços de aproximadamente $5 \mathrm{~cm}$, permitindo assim sua passagem pelo britador de mandíbulas. Este por sua vez produz a fragmentação da rocha a uma granulometria inferior a $0,5 \mathrm{~cm}$;

-O material britado é então reduzido a uma granulometria entre 100 e 250 mesh utilizandose de um moinho de discos e um jogo de peneiras;

-As frações entre 100 e 250 mesh são processadas em mesa concentradora (Mesa de Wiffley) para a concentração dos minerais pesados. No caso das rochas de natureza básica aconselha-se ainda, a passagem das frações inferiores a 250 mesh, pois os zircões tendem a apresentar dimensões bastante reduzidas concentrando-se nas frações mais finas;

-Após esta etapa, utilizando-se de um ímã de mão, são retirados os minerais intensamente magnéticos (magnetitas).

-Este material é então processado em um separador eletromagnético tipo Frantz com corrente variável entre 0,5 e 1,0 A, com inclinação frontal de $20^{\circ}$ e lateral de $10^{\circ}$ para separação dos minerais magnéticos (biotitas, anfibólios e piroxênios);

-A fração não magnética, onde se concentram os zircões é tratada a seguir com líquidos densos: Bromofórmio $\left(\mathrm{d}=2,85 \mathrm{~g} / \mathrm{cm}^{3}\right)$ e Iodeto de Metileno $\left(\mathrm{d}=3,2 \mathrm{~g} / \mathrm{cm}^{3}\right)$. Este processo, envolvendo líquidos densos, pode ser repetido diversas vezes até que o concentrado final, rico em zircões, fique praticamente isento de impurezas.

-Um novo processamento em separador eletromagnético (Frantz), dessa vez, com corrente de 1,2 A muitas vezes é necessário.

-Posteriormente é realizado o tratamento do concentrado $\left(\mathrm{d}>3,2 \mathrm{~g} / \mathrm{cm}^{3}\right)$ com ácidos $\left(\mathrm{HNO}_{3}\right.$ e $\mathrm{HCl}$ ) com a finalidade de eliminar sulfetos e apatitas;

-O concentrado obtido é então processado cuidadosamente em separador eletromagnético (tipo Frantz), desta vez utilizando-se de uma técnica denominada split. A amperagem neste processo é mantida constante $(1,5 \mathrm{~A})$, bem como a inclinação frontal $\left(10^{\circ}\right)$, modificando-se gradativamente as inclinações laterais $\left(10^{\circ}, 8^{\circ}, 6^{\circ}, \ldots\right)$, obtendo-se as frações (M10, M8, M6,...) com diferentes suscetibilidades magnéticas (a tiltes de 10, 8, 6,...). Este procedimento tem por objetivo concentrar populações de zircões com diferentes susceptibilidades magnéticas, numa tentativa de se obter diferentes relações $\mathrm{U}-\mathrm{Pb}$. 
-As diferentes frações obtidas são então analisadas cuidadosamente em lupa binocular, onde é realizada a seleção dos cristais por catação manual. Busca-se analisar populações formadas por tipologias de zircões similares, límpidos, sem inclusões ou fraturas.

\section{Técnicas Analíticas}

Nas determinações isotópicas U-Pb as técnicas analíticas mais utilizadas são as seguintes:

- Metodologia U-Pb Convencional (diluição isotópica/TIMS)

Nesta metodologia cada fração (preferencialmente as menos magnéticas) é cuidadosamente examinada em lupa binocular, onde é realizada a seleção e a limpeza final dos concentrados de zircões. É comum realizar-se a escolha destes minerais por catação manual ('hand picking') até ser atingida a quantidade de cristais necessária (função da idade e do grau de contaminação laboratorial presente). Nesta fase os zircões podem ser submetidos à abrasão mecânica através de um sistema que envolve ar comprimido e pirita para eliminação das porções mais externas normalmente mais metamícticas. Maiores informações relacionadas à implantação desta metodologia no CPGeo-USP, envolvendo a utilização dos isótopos de $\mathrm{U}$ e $\mathrm{Pb}$, bem como procedimentos químicos e espectrométricos podem ser encontrados em Basei et al. (1995).

Atualmente no CPGeo-USP utiliza-se para o ataque químico desde 1 (um) cristal até cerca de $50 \mu \mathrm{g}$ de zircões (para cada população). Os cristais, depois de selecionados e armazenados em savillex, são submetidos a descontaminação, utilizando-se de reagentes bastante puros $\left(\mathrm{HCl}, \mathrm{HNO}_{3}\right.$ e água tridestilada), com aquecimento e utilização de ultra-som. A adição de spike ${ }^{205} \mathrm{~Pb}$ (diluição isotópica) é realizada quando do ataque químico com HF e $\mathrm{HCl}$ (destilados e com baixíssimo conteúdo de $\mathrm{Pb}$ ), em micro bombas de teflon, em uma estufa a temperaturas da ordem de $200^{\circ} \mathrm{C}$, permanecendo por cerca de 3 dias. Posteriormente a solução é processada em colunas com resina de troca aniônica (AG-1X8), previamente calibradas, permitindo a coleta de $\mathrm{U}$ e $\mathrm{Pb}$. Após secagem, este concentrado é depositado em filamento de rênio e analisado em espectrômetro de massa multi coletor por termo ionização (TIMS) Finnigan MAT 262, detalhado em Sato \& Kawashita (2002). No CPGeo os valores médios medidos para os padrões NBS-981 e NBS-983 são respectivamente de:

${ }^{204} \mathrm{~Pb} /{ }^{206} \mathrm{~Pb}=0,05903+-0,02 \%$ e $0,000368+-3 \%$ 
${ }^{207} \mathrm{~Pb} /{ }^{206} \mathrm{~Pb}=0,91479+-0,01 \%$ e $0,071212+-0,05 \%$

${ }^{208} \mathrm{~Pb} /{ }^{206} \mathrm{~Pb}=2,1675+-0,01 \%$ e $0,013617+-0,06 \%$ com variação anual de 1 . O fator de correção de fracionamento utilizado é de 0,095 u.m.a. (unidade de massa atômica). Os resultados foram calculados em programa ISOPLOT (Ludwig, 2003) e representados como desvios de $2^{\sim}$ As constantes utilizadas referem-se as recomendadas por Steiger \& Jäger (1977):

$\lambda^{238}=1,55125 \times 10^{-10} \operatorname{anos}^{-1}$

$\lambda^{235}=9,8485 \times 10^{-10}$ anos $^{-1}$

O traçador (spike) utilizado é o ${ }^{205} \mathrm{~Pb}$, e o branco total obtido é da ordem de $10 \mathrm{pg}$.

\section{-EVITIMS (Evaporation Thermal Ionization Mass Spectrometry)}

A técnica de evaporação por ionização termal em espectrômetro de massa é aplicada diretamente em monocristais de zircão.

Esta metodologia foi desenvolvida por Kober (1986) e consiste na análise por evaporação de zircão diretamente no filamento do espectrômetro, sem utilizar as rotinas químicas ou adição de spike, a exemplo do método convencional.

Trata-se de uma ferramenta poderosa para análise da composição isotópica do zircão, podendo caracterizar idades $(\mathrm{Pb}-\mathrm{Pb})$ distintas em um único cristal (borda e núcleo). Este procedimento não permite a obtenção de relações $\mathrm{U}-\mathrm{Pb}$, sendo somente utilizado para a obtenção de razões isotópicas de $\mathrm{Pb}$. A qualidade dos resultados obtidos depende diretamente do tamanho do cristal analisado, idade, assim como das dimensões relativas de bordas (recristalização) e núcleos (herança).

Nesta técnica o cristal de zircão é colocado diretamente em uma cavidade no formato de canoa, no centro de um filamento de rênio contendo uma solução de $\mathrm{H}_{2} \mathrm{PO}_{4}$ $(0,1 \mathrm{~N})$ e sílica gel, que facilita a fixação do grão. Este é então analisado em espectrômetro com aquecimento gradativo (step and heat) até temperaturas onde ocorre a ionização do $\mathrm{Pb}$. Quando as temperaturas são próximas de $1300^{\circ} \mathrm{C} \mathrm{o} \mathrm{Pb}$ das bordas do zircão é ionizado e após os $1400^{\circ} \mathrm{C}$ o processo de ionização atinge o núcleo do cristal. Com isso, é possível obter relações ${ }^{207} \mathrm{~Pb} /{ }^{206} \mathrm{~Pb}$ do início (bordas do cristal) ao final da análise (núcleo). É importante salientar que esta técnica não apresenta precisão quando as bordas de recristalização são pouco expressivas, função da quantidade elevada de $\mathrm{Pb}$ comum presente 
no início do aquecimento. Os resultados apresentados com desvios de 2 e as correções de $\mathrm{Pb}$ (comum) são realizadas utilizando-se o modelo de evolução do $\mathrm{Pb}$ proposto por Stacey \& Kramers (1975). Os valores obtidos referem-se a idades aparentes ${ }^{207} \mathrm{~Pb} /{ }^{206} \mathrm{~Pb}$. Pormenores desta técnica podem ser encontrados em Sato et al. 2001.

\section{A Metodologia U-Pb (zircão) Aplicada a Rochas Metabásicas}

No caso de rochas de natureza básica, recomendam-se alguns cuidados especiais, notadamente quando da coleta das amostras e reconhecimento dos zircões em lupa, necessitando na maioria das vezes de análise de imagens através da técnica de catodoluminescência. No caso da coleta de amostras, o volume de material deve ser relativamente elevado (cerca de $20 \mathrm{Kg}$ ), uma vez que a quantidade de zircões nesses litotipos é bastante reduzida. Cuidados especiais devem ser tomados na etapa de concentração em mesa, uma vez que os zircões presentes normalmente têm dimensões reduzidas (recomenda-se a passagem de frações inferiores a 250 mesh).

Na etapa de seleção e catação de cristais (em lupa) as dificuldades residem no reconhecimento dos zircões. Estes nem sempre apresentam hábitos prismáticos, com arestas e biterminações definidas. Muitas vezes são tabulares, disformes, com inclusões, ricos e fraturas e com tonalidades variadas.

Essa morfologia do zircão é atribuída à sua cristalização ígnea, que ocorre de forma rápida nas fases residuais da fusão. O caráter metamórfico pode gerar bordas de recristalização (idade do evento metamórfico) e zonas de núcleo (herança), bem como a neocristalização de zircões.

A escolha da melhor técnica analítica a ser utilizada deve levar em consideração todos estes parâmetros, que só poderão ser corretamente reconhecidos após estudos de imagens obtidas através de catodoluminescência e/ou luz transmitida. Estas técnicas permitem analisar com clareza a estrutura interna dos zircões, diferenciando zonas de sobrecrescimento, zonas aleatórias (interferência) e núcleos preservados. Tais características são fundamentais às interpretações geológicas, seja utilizando-se do método convencional (TIMS), ou mesmo através das técnicas SHRIMP ou laser ablation-ICP-MS. Datar com precisão feições de borda (metamorfismo) e núcleo (porção ígnea do cristal) é de fundamental importância ao estudo pretendido. 


\subsubsection{Sistemática Isotópica Sm-Nd}

Aspectos Teóricos e Laboratoriais

O desenvolvimento do método Sm-Nd iniciou-se na década de 70, a partir de estudos de meteoritos e rochas lunares (Lugmair et al. 1975 a e b; Nakamura et al. 1976). Com a melhor compreensão do comportamento dos isótopos de $\mathrm{Sm}$ e $\mathrm{Nd}$ nos processos geológicos e de suas características geoquímicas no manto superior e na crosta continental, a sistemática $\mathrm{Sm}-\mathrm{Nd}$ tem se mostrado uma importante ferramenta para os estudos de evolução crustal, permitindo determinar grandes períodos de acresção continental.

O Sm e o Nd são dois elementos do grupo dos Terras Raras (ETR) ou lantanídeos, com raios iônicos bastante próximos (0,96 e 1,0 A), e com mesma valência, o que os torna praticamente elementos isoquímicos. Este fato resulta em razões $\mathrm{Sm} / \mathrm{Nd}$ pouco diferenciadas, variando de 0,1 a 0,37 entre os diversos minerais e rochas.

Outra característica é a probabilidade bastante remota de fracionamento desses elementos, fazendo com que a razão $\mathrm{Sm}-\mathrm{Nd}$ seja dificilmente modificada, mesmo por eventos geológicos superimpostos (De Paolo 1988).

$\mathrm{O} \mathrm{Sm}$ e o $\mathrm{Nd}$ são encontrados em quase todas as rochas, em geral substituindo elementos de íons grandes. Ocorrem principalmente nos clinopiroxênios, anfibólios, granadas, micas e feldspatos que constituem os principais minerais analisados por esse método. Em alguns casos os ETR são concentrados, como constituintes principais de alguns minerais acessórios de rochas graníticas, como, por exemplo, as alanitas, monazitas, xenotímio, columbita-tantalita, fluorita, scheelita e cassiterita. Quando o sistema rocha total é enriquecido nestes minerais acessórios pode ocorrer um fracionamento de $\mathrm{Sm}-\mathrm{Nd}$ com a diferenciação magmática, modificando substancialmente a razão Sm-Nd (Pimentel \& Charnley 1991 ; Corey \& Chatterjee 1990).

As amostras coletadas para fins geocronológicos devem ser isentas de alteração intempérica e representativas do afloramento a ser analisado.

Este material deve ser reduzido a uma granulometria inferior a 250 mesh, normalmente pulverizado. Os procedimentos químicos que visam a concentração de Sm e Nd podem ser sintetizados da seguinte maneira

1. Pesagem em savillex (entre 50 e $100 \mathrm{mg}$ );

2. Adição de spike combinado Sm-Nd; 
3. Ataque químico envolvendo $\mathrm{HF}, \mathrm{HCl}$ e $\mathrm{HNO}_{3}$ conforme rotina do laboratório Sm-Nd do CPGeo-IGC-USP (Sato et al, 2003).

4. Separação do $\mathrm{Sm}$ e do $\mathrm{Nd}$ (nessa fase foi coletado o $\mathrm{Sr}$, para fins petrogenéticos: $\boldsymbol{E}_{\mathrm{Sr}}$ ) em colunas catiônicas tipo AG-50W-X8 (200-400 mesh);

5. Deposição dos concentrados de $\mathrm{Sm}$ e $\mathrm{Nd}$ em filamentos ultra descontaminados e análise em espectrômetro de massa.

6.

No CPGeo os valores médios medidos para os padrões de $\mathrm{Nd}$ La Jolla e BCR-1 são: ${ }^{143} \mathrm{Nd} /{ }^{144} \mathrm{Nd}=0,511849+-0,000025$ e $0,512662+-0,000027$, respectivamente (variação anual de 1 ). Erros máximos medidos das razões ${ }^{143} \mathrm{Nd} /{ }^{144} \mathrm{Nd} \mathrm{e}{ }^{147} \mathrm{Sm} /{ }^{144} \mathrm{Nd}$, em amostras, são inferiores a 0,004\% e 0,01\%, respectivamente, com nível de precisão de 2 . As razões isotópicas foram obtidas em espectrômetros de massa multi-coletor Finnigan MAT-262, enquanto as de Sm foram analisadas com espectrômetro mono-coletor VG-354. O branco total foi da ordem de $0,4 \mathrm{ng}$ para o $\mathrm{Nd}$ e $0,7 \mathrm{ng}$ para o $\mathrm{Sm}$. Os cálculos de idades-modelo foram baseados em valores publicados em De Paolo et al. (1991): ${ }^{143} \mathrm{Nd} /{ }^{144} \mathrm{Nd}=0,7219$ e ${ }^{143} \mathrm{Nd} /{ }^{144} \mathrm{Nd}(\mathrm{CHUR})=0,512638 \mathrm{e}{ }^{147} \mathrm{Sm} /{ }^{144} \mathrm{Nd}(\mathrm{CHUR})_{\mathrm{o}}=0,1967$.

\section{Idades Isocrônicas}

Pelo fato do $\mathrm{Sm}$ e $\mathrm{Nd}$ possuírem comportamentos geoquímicos similares, existe grande dificuldade na obtenção (em rochas cogenéticas) de diferenças significativas nas razões $\mathrm{Sm} / \mathrm{Nd}$, fundamentais à distribuição adequada dos pontos analíticos no diagrama.

Idades isocrônicas $\mathrm{Sm}-\mathrm{Nd}$, em rocha total, representam épocas relacionadas à cristalização de rochas ígneas ou recristalização metamórfica, similarmente ao observado nas metodologias: $\mathrm{Rb}-\mathrm{Sr}$ e U-Pb (zircão).

São utilizadas muitas vezes em rochas de natureza básica, onde as idades modelo são de difícil interpretação e normalmente com erros bastante elevados (relações próximas às observadas para a curva de evolução dos materiais do manto).

Sistemas isocrônicos minerais podem também ser utilizados, principalmente quando da presença de granada (elevadas razões $\mathrm{Sm} / \mathrm{Nd}$ ). Representam a época de cristalização dos minerais datados. Cuidados especiais, envolvendo estudos petrográficos, devem ser 
tomados uma vez que os minerais analisados devem representar o mesmo evento petrogenético.

\section{Idades Modelo}

A grande modificação nas razões $\mathrm{Sm} / \mathrm{Nd}$ ocorre quando da diferenciação mantocrosta. Neste processo ocorre um enriquecimento relativo de $\mathrm{Nd}$, função de sua menor relação carga/raio. Portanto, a modificação substancial da razão $\mathrm{Sm} / \mathrm{Nd}$ ocorre quando da diferenciação manto-crosta, sendo posteriormente pouco modificado por processos crustais.

$\mathrm{O}$ fato das razões $\mathrm{Sm} / \mathrm{Nd}$ modificarem-se significativamente quando da diferenciação manto-crosta permite a obtenção de idades denominadas modelo. Relacionam-se a épocas em que o protólito crustal da rocha analisada diferenciou-se do manto superior. O cálculo de idades modelo torna-se possível através da determinação das razões ${ }^{147} \mathrm{Sm} /{ }^{144} \mathrm{Nd} \mathrm{e}{ }^{143} \mathrm{Nd} /{ }^{144} \mathrm{Nd}$ atuais da amostra, e por regressão até o intercepto com a curva de evolução isotópica do $\mathrm{Nd}$ estabelecida para o manto superior. Atualmente, são dois os principais modelos utilizados para a evolução isotópica de $\mathrm{Nd}$ no manto superior. O primeiro se fundamenta na evolução dos condritos (CHUR= Condritic Uniform Reservoir), e o segundo, mais utilizado, refere-se ao modelo de manto empobrecido (DM= Depleted Mantle), que admite um manto residual enriquecido na razão $\mathrm{Sm} / \mathrm{Nd}$ e empobrecido geoquimicamente em elementos litófilos de íons grandes.

\section{O parâmetro $\varepsilon N d$ aplicado a estudos petrogenéticos}

$\mathrm{O}$ parâmetro $\varepsilon \mathrm{Nd}$ consiste basicamente na comparação da razão ${ }^{143} \mathrm{Nd} /{ }^{144} \mathrm{Nd}$ da rocha analisada com um reservatório condrítico uniforme padrão (CHUR), representativo da Terra Global. Esse cálculo é realizado para um determinado tempo, normalmente quando da formação da rocha. Se, quando da cristalização da rocha, a razão ${ }^{143} \mathrm{Nd} /{ }^{144} \mathrm{Nd}$ for similar ao valor observado para o condrito na mesma época, o índice de $\varepsilon \mathrm{Nd}$ será próximo a zero (pouco positivo ou pouco negativo). Neste caso, a formação da rocha, em níveis crustais superiores, ocorreu logo após a diferenciação de seus protólitos do manto superior. Por outro lado, se quando da formação da rocha, o parâmetro $\varepsilon N d$ for negativo, implica 
numa relação $143 \mathrm{Nd} / 144 \mathrm{Nd}$ da rocha, inferior ao observado para o modelo condrítico, na época assinalada. Resulta, portanto em residência crustal, tanto maior quanto mais negativo o valor de $\varepsilon N d$.

Os valores médios de $\varepsilon \mathrm{Nd}$ são da ordem de: arcos de ilhas oceânicas $=+8$, cadeias de ilhas intraplaca (hot spots) $=0 \mathrm{a}+8$, crista meso-oceânica $=+10$, montanhas de fundo do mar

de pequeno volume $($ off ridge $)=+5 \mathrm{a}+10$, crátons continentais $=-5$, rifts continentais $=-5 \mathrm{a}$ +8 e arcos de margens continentais $=-20 \mathrm{a}+8$. (De Paolo, 1988).

\section{A metodologia Isotópica Sm-Nd aplicada às rochas metabásicas}

As determinações de idades modelo $\mathrm{Sm}-\mathrm{Nd}$ em rochas de natureza básica são dificultadas, uma vez que possuem relações $\mathrm{Sm} / \mathrm{Nd}$ relativamente próximas a curva de evolução do manto. Tal fato é observado através de curvas de evolução desses litotipos pouco inclinadas, ou mesmo relativamente paralelizadas à do manto superior. Nessas rochas é aconselhável a realização de várias determinações isotópicas numa tentativa de se utilizar de sistemas isocrônicos.

\subsubsection{Metodologia Isotópica Rb-Sr:}

Rochas de natureza básica/ ultrabásica apresentam teores de Rb bastante baixos, de difícil quantificação, mesmo quando utilizadas técnicas refinadas com emprego de spikes (diluição isotópica). As baixas relações $\mathrm{Rb} / \mathrm{Sr}$ obtidas nestes litotipos e a pouca dispersão das mesmas, dificulta a utilização de diagramas isocrônicos. As idades isocrônicas em rocha total, relativas a conjuntos rochosos cogenéticos, têm grande importância na caracterização de episódios formadores de rocha, em sentido extenso, por meio de quaisquer processos petrogenéticos que conduzam ao aparecimento de associações minerais bem definidas provenientes de cristalização magmática ou recristalização metamórfica.

A utilização da metodologia $\mathrm{Rb} / \mathrm{Sr}$, no entanto, não se limita a determinação de idades, tendo grande importância na obtenção das relações ${ }^{87} \mathrm{Sr} /{ }^{86} \mathrm{Sr}$ e através delas, do índice Sr. Tais índices são fundamentais à obtenção de informações petrogenéticas relacionadas a reservatórios de origem crustal ou mesmo de crosta inferior/ manto superior. As razões iniciais $\left({ }^{87} \mathrm{Sr} /{ }^{86} \mathrm{Sr}\right)$ obtidas em meteoritos têm mostrado bastante homogêneas e próximas de 0,69899 (BABI: Basaltic Achondrite Best Initial) e têm sido associadas como 
bastante representativos da razão $\left({ }^{87} \mathrm{Sr} /{ }^{86} \mathrm{Sr}\right.$ ) da nebulosa solar (estágios iniciais da formação de corpos planetários).

A composição isotópica do $\mathrm{Sr}$ no manto da Terra tem sido também largamente estudada através da análise de basaltos e de corpos gabróicos, que acredita -se que tenham origem no manto, sem contaminação significativa com $\mathrm{Sr}$ crustal. Os resultados sugerem que as razões atuais $\left({ }^{87} \mathrm{Sr} /{ }^{86} \mathrm{Sr}\right)$ se aproximem do intervalo $0,704+-0,002$. Alguns valores médios em rochas vulcânicas modernas são apresentados por Faure (1986): Fundos Oceânicos $(0,70280)$, Ilhas Oceânicas $(0,70386)$; Arcos de Ilhas $(0,70437)$ e Continentes $(0,70577)$.

O parâmetro Sr refere-se à composição da razão $\left({ }^{87} \mathrm{Sr} r{ }^{86} \mathrm{Sr}\right)$ da rocha analisada com um reservatório condrítico uniforme (CHUR). Este cálculo é realizado para um determinado tempo, normalmente quando da formação da rocha. Caso a razão $\left({ }^{87} \mathrm{Sr} r{ }^{86} \mathrm{Sr}\right)$ se mostre similar ao valor observado para o condrito, na mesma época, o índice sr será próximo a zero. Neste caso a formação da rocha ocorreu logo após a diferenciação de seus protolitos do manto superior. Caso este valor se mostre positivo, resulta em residência crustal tanto maior quanto mais elevado o valor de sr. A utilização conjunta deste índice com o Nd permite a obtenção de importantes informaçãoes petrogenéticas (Sato, 1998).

Os procedimentos analíticos utilizados no CPGeo são os mesmos adotados para o método $\mathrm{Sm}-\mathrm{Nd}$ podendo o $\mathrm{Rb}$ ser determinado diretamente por fluorescência de raios-X ( $50 \mathrm{ppm}<\mathrm{Rb}<500 \mathrm{ppm}$ ) ou utilizando-se de spike (diluição isotópica). O espectrômetro de massa utilizado é o VG-354- monocoletor. No CPGeo o valor médio medido para o padrão NBS-987 é de $0,71025\left({ }^{87} \mathrm{Sr} /{ }^{86} \mathrm{Sr}\right)$ com variação anual de 1 . As relações de $\mathrm{Sr}$ são normalizadas em função da razão ${ }^{86} \mathrm{Sr} /{ }^{87} \mathrm{Sr}=0,1194$, sendo as constantes utilizadas aquelas recomendadas por Steiger \& Jäeger (1978): $\mathrm{Rb}=1,42 \mathrm{X}^{-11} 0^{-1} \mathrm{anos}^{-1} ;\left({ }^{85} \mathrm{Rb} /{ }^{87} \mathrm{Rb}\right)_{\mathrm{N}}=$ 2,59265 . 


\subsection{COMPARTIMENTAÇÃO TECTÔNICA}

O Domínio Apiaí é constituído por rochas meso a supracrustais de baixo a médio grau metamórfico, representado pelas seqüências metavulcanossedimentares do Supergrupo Açungui (Campanha e Sadowiski, 1999). Rochas granito-gnáissicas representantes de sua infra-estrutura ocorrem como pequenos núcleos denominados de: Núcleo Betara e Núcleo do Tigre (Kaulfuss, 2001). Inúmeras são as propostas de empilhamento estratigráfico dessas seqüências, dificultadas por uma sucessão de eventos tectônicos ocorridos principalmente durante o Neoproterozóico e responsáveis pela aloctonia dessas unidades geológicas. Outro fator importante, refere-se a 
dificuldade em determinar com precisão épocas relacionadas a sedimentação dessas seqüências. Atualmente com o desenvolvimento e aperfeiçoamento da metodologia U-Pb, permitindo a datação de poucos ou mesmo um único cristal de zircão (TIMS), utilização de técnicas SHRIMP e estudos de catodoluminescência, tal quadro vem sendo modificado, permitindo um melhor conhecimento geocronológico (sedimentação / metamorfismo) dessas seqüências e, conseqüentemente, do empilhamento estratigráfico regional.

As características litoestratigráficas e estruturais, acopladas a recentes pesquisas geocronológicas, notadamente em zircões (U-Pb: TIMS e SHRIMP), permitem reconhecer no sul da Faixa Ribeira cinco (5) importantes compartimentos tectônicos , conforme ilustrado na figura 3.1. São balizados por importantes zonas de cisalhamento, num contexto geotectônico cuja dinâmica deformacional é ainda incerta. Representam aproximadamente os compartimentos tectônicos individualizados por Gois et al..(1985), de onde se referem grande parte das denominações aqui utilizadas. É importante salientar que o termo "compartimento tectônico"aqui utilizado é puramente descritivo, sem qualquer conotação genética, uma vez que a aplicação de nomenclaturas adequadas (microcontinentes, microplacas, terrenos suspeitos, alóctones, exóticos, blocos acrescionários , agregados complexos, margem de placas, etc.) requerem profundas e minuciosas pesquisas relativas a origem, formas, limites, movimentos, arranjos e deformação, conforme discutido por diversos autores, a exemplo de Jones et al., (1983) Dover (1990), Sengor e Dewey (1990), Jones (1995).

O Compartimento Socavão (figura3.1) inclui a Faixa Itaiacoca e o Batolito Granítico Cunhaporanga. $\mathrm{O}$ caráter intrusivo desse batolito granítico nas seqüências metavulcanossedimentares da Faixa Itaiacoca (setor NW) foi caracterizado por diversos autores, a exemplo de Fuck et al. , 1967; Guimarães, 2000 e Prazeres Filho , 2000.e 2005. Dados isotópicos U-Pb zircão obtidos por Prazeres Filho, 2000 e 2005 indicam valores do intervalo entre 630-600 MA. para a formação de grande parte das rochas que compões esse batólito granítico. O contato sudeste da Faixa Itaiacoca, por outro lado, é tectônico, balizado pela zona de cisalhamento Itapirapuã (Fiori et al. , 1984). Os dados geológico-geocronológicos recém obtidos para a seqüência Itaiacoca (Siga Junior et al.., 2006) sugerem a presença de dois conjuntos litológicos temporalmente distintos, o primeiro representado principalmente por metacalcários dolomíticos e metamargas com idades mínimas de deposição relacionadas ao final do Mesoproterozóico / início do Neoproterozóico (1030-908 Ma). O segundo conjunto é representado principalmente por metarcóseos, metavulcâncais, metaconglomerados e metapelitos com idades de deposição relacionadas ao Neoproterozóico (645-628 Ma).

O Batolito Granítico Três Córregos (Prazeres Filho, 2000 e 2005), que ocorre a sul-sudeste da zona de cisalhamento Itapirapuã, se mostra intrusivo nas seqüências metavulcanossedimentares 
da Formação Água Clara (Marini et al., 1967), cuja idade mínima de sedimentação relaciona-se ao Mesoproterozóico ( 1.600 - $1.500 \mathrm{Ma}$; Weber et al.., 2004). Incluem-se no aqui denominado Compartimento Cêrro Azul, balizado a sul-sudeste pelos lineamentos Morro Agudo e Quarenta Oitava ( figura 3.1).

As seqüências metavulcanossedimentares Lajeado (Campanha et al., 1986) e Antinha (Dias e Salazar Jr. , 1987), distribuem-se entre os lineamentos Morro Agudo , Ribeira, Figueira e Quarenta Oitava, e estão incluídas no Compartimento Guapiara. Apresentam idades de sedimentação relacionadas ao Neoproterozóico ( 600 Ma ; Hackspacher et al.. , 2000; Campanha et al.., 2004).

O Compartimento Rio Ribeira é o de maior interesse uma vez que inclui as sequências metavulcanossedimentares Votuverava (Bigarella e Salamuni, 1958), Perau (Piekarz, 1981), Núcleos do Tigre e Betara (este último,objeto deste trabalho), bem como inúmeros maciços graníticos tardi à pós tectônicos (580-560Ma) a exemplo dos maciços do Morro Grande, Cerne, Passa Três, Rio Abaixo, Capivara e Chacrinha. Limita-se a sul pelo lineamento Lancinha e a norte pelos lineamentos Morro Agudo, Ribeira e Figueira. Registros isotópicos relacionados a tafrogênese Estateriana $(\sim 1.750 \mathrm{Ma})$ foram identificadas em sienogranitos e rochas metabásicas com características anorogênicas no âmbito dos Núcleos do Tigre e Betara ( Kaulfuss, 2001; Cury et al. , 2002; Siga Jr. et al., 2005; Ribeiro et al., 2005 ). Adicionalmente idades (mínimas) relacionadas a sedimentação das sequências Votuverava, Perau e Betara referem-se ao Mesoproterozóico (1.500 1.450 Ma ; Basei et al., 2003 a e b ; Ribeiro et al., 2005).

As seqüências Capirú (Bigarella e Salamuni, 1956) e Turvo - Cajati (Silva e Algarte, 1981; Faleiros e Campanha ,2005) distintamente ocorrem a sul do lineamento Lancinha, no Compartimento Bocaiúva do Sul, âmbito dos terrenos gnáissico - migmatíticos do Complexo Atuba (Siga Jr. et al., 1996). Não existem estudos geocronológicos que caracterizem épocas relacionadas a sedimentação dessas seqüências ,fundamentais a evolução tectônica deste setor.

Observa-se portanto no Domínio Apiaí importantes compartimentos tectônicos colocados lado a lado por expressivas zonas de cisalhamento ,que incluem cavalgamentos e transcorrências (Fiori ,1990),num contexto deformacional cuja dinâmica é ainda incerta. Nesses compartimentos destacam-se registros de magmatismo e expressiva sedimentação associados a processos extensionais do final do Paleoproterozóico (1.750 Ma) e do Mesoproterozóico (1.600 - 1.450 Ma) ,bem como a regimes compressivos do Neoproterozóico ( 600 Ma). Não existem ,até o momento ,dados geocronológicos que caracterizem uma tectônica relacionada a processos compressivos do Mesoproterozóico ou mesmo do início do neoproterozóico. A tectônica Neoproterozóica é 
responsável pelo metamorfismo e colocação de importantes maciços graníticos, a exemplo do Cunhaporanga e Três Córregos, admitidos como arcos magmáticos
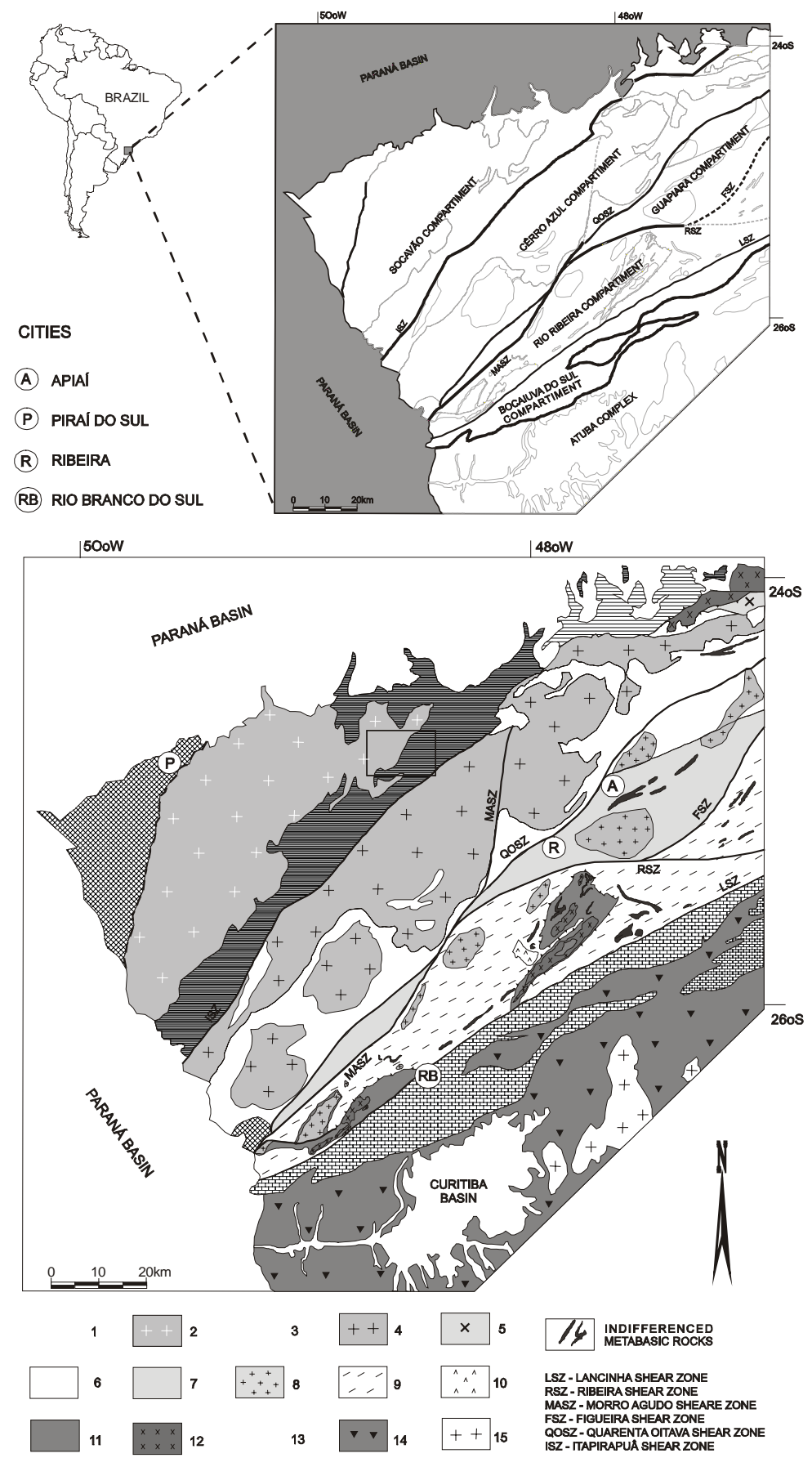

Figura 3.1: Esquema geológico-tectônico (leste do Paraná e sudeste de São Paulo):

Bacias Foreland: 1 - Grupo Castro / Formação Camarinha; Compartimento Socavão: 2 - Batolito Cunhaporanga [630-600Ma]; 3 - Faixa Itaiacoca [seqüência inferior c.a.1000Ma; seqüência superior c.a. 630Ma]; Compartimento Cêrro Azul: 4 - Batolito Três Córregos [650-600Ma]; 5 - Batolito Agudos Grandes; 6 - Seqüência Água Clara [c.a.1450Ma]; Compartimento Guapiara: 7 - Seqüência Lajeado / Antinha [600Ma]; 8 - granitóides sin a pós-colisionais[560-590Ma]; Compartimento Rio Ribeira: 9 Seqüência Votuverava [1450Ma]; 10 - Sienito Tunas [82Ma]; 11 - Seqüências Perau e Betara [1450Ma]; 12 - sienogranitos miloníticos [1750Ma] e granitóides cálcio-alcalinos miloníticos [2100Ma]; Compartimento 
Bocaiúva do Sul: 13 - Seqüências Capiru / Turvo Cajati; 14 - Complexo Gnáissico-Migmatítico Atuba; 15 Suíte Granítica Serra do Mar [590-600Ma].

\subsection{GEOLOGIA DA ÁREA}

As exposições de rochas metavulcanossedimentares da Formação Betara e graníticas (sienogranitos e granodioritos) proto a miloníticas do Núcleo Betara distribuem-se no âmbito do Compartimento Ribeira do seguinte modo (conforme mapa e perfis anexos):

Porção Oriental: As sequências metavulcanossedimentares são balizadas à norte com a Formação Votuverava pela Falha do Betara (cavalgamento para S-SE) e a sul com a Formação Capirú pela Zona de Cisalhamento Lancinha (transcorrente dextral ).

Porção Central: As sequências metavulcanossedimentares são balizadas a norte com a Formação Votuverava pela Falha dos Lara (cavalgamento para S-SE) e a sul (onde ocorrem os litotipos sienograníticos e granodioríticos) pela Formação Capiru pela Zona de Cisalhamento Lancinha.

Porção Ocidental: As sequências metavulcanossedimentares são balizadas a norte com a Formação Votuverava pela Falha do Cerne (transcorrente dextral) e a sul também com a Formação Votuverava pela Falha da Boa Vista (cavalgamento para S-SE).

As rochas metavulcanossedimentares da Formação Betara e graníticas (sienograníticas e granodioríticas) proto a miloníticas do Núcleo Betara apresentam portanto relações tectônicas com as sequências metavulcanossedimentares da Formação Votuverava e metassedimentos da Formação Capiru.

Estudos litoestratigráficos detalhados das sequências metavulcanossedimentares da Formação Betara se devem principalmente a Piekarz (1983 e 1984) em projeto realizado pela Mineropar, abrangendo o setor oriental da área, que contou com a realização de três furos de sondagem. As descrições relativas às unidades de mapeamento realizadas a seguir têm por base perfis contínuos realizados no setor oriental e ocidental (mapa geológico anexo) bem como do reconhecimento geológico de porções centrais da área. Adicionalmente se utiliza de dados existentes na literatura, notadamente de Piekarz (1983 e 1984), Fiori (1990), Kaulfuss (2001) e Cury (2003).

\subsection{Núcleo Betara}

Os terrenos pertencentes ao Núcleo Betara, incluídos por diversos autores como representantes do embasamento são constituídos em sua quase totalidade por granitóides de composição sienogranítica e granodiorítica. Estas rochas encontram-se afetadas por 
cisalhamentos de natureza rúptil-dúctil à dúctil resultando em estruturas protomiloníticas, miloníticas e ultramiloníticas. O padrão estrutural observado permite distinguir uma foliação de baixo à médio ângulo truncada por sistemas transcorrentes subverticais. Estes granitóides deformados distribuem-se na porção centro-sul da área estudada, junto à Zona de Cisalhamento Lancinha.

\section{Granodioritos proto-miloníticos a miloníticos}

A classificação destes litotipos como granodioritos deve-se principalmente a estudos geoquímicos realizados por Kaulfuss (2001). Os estudos aqui realizados referem-se a observações macro e microscópicas.

As rochas granodioríticas proto a miloníticas ocorrem pouco à norte da Zona de Cisalhamento Lancinha, próximas ao contato com o Complexo Atuba (a sul). Apresentam cor cinza clara à cinza rosada e porfiroclastos de feldspatos com dimensões centimétricas, normalmente estirados e rotacionados (figura 4.1).

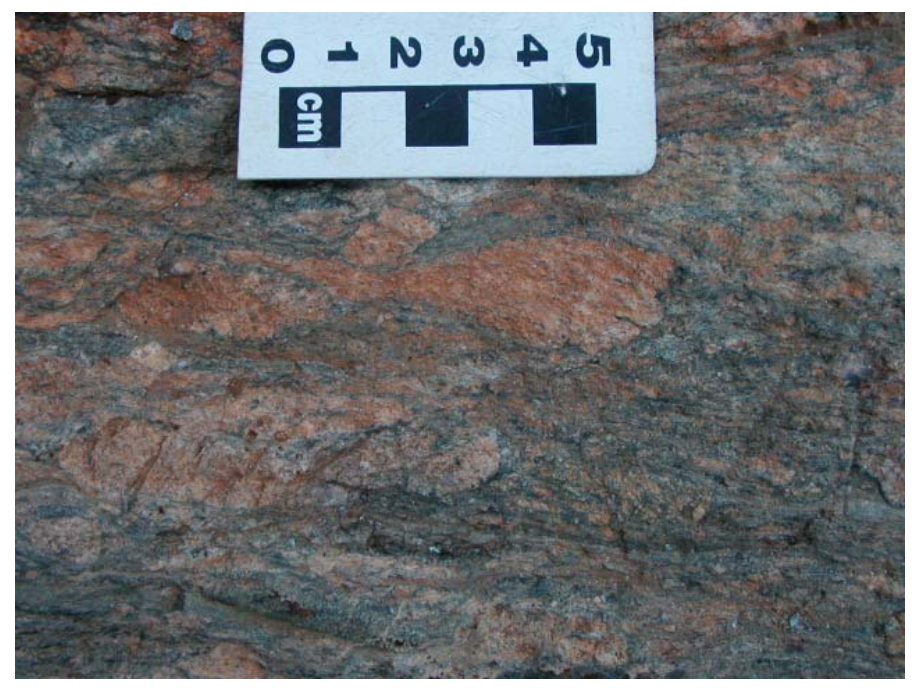

Figura 4.4: Porfiroclastos de feldspatos centimétricos estirados e rotacionados

A matriz apresenta granulometria fina a média e composição à base de quartzo, feldspato, biotita, sericita e clorita. Os feldspatos, de um modo geral, apresentam-se intensamente fraturados e micro-falhados, alguns exibindo formas sigmoidais e estruturas tipo dominó, indicando uma movimentação dextral. Adquirem muitas vezes feições miloníticas à ultramiloníticas, destacando-se a presença de micrólitons do próprio milonito em meio a matriz ultramilonítica (figura 4.2). 


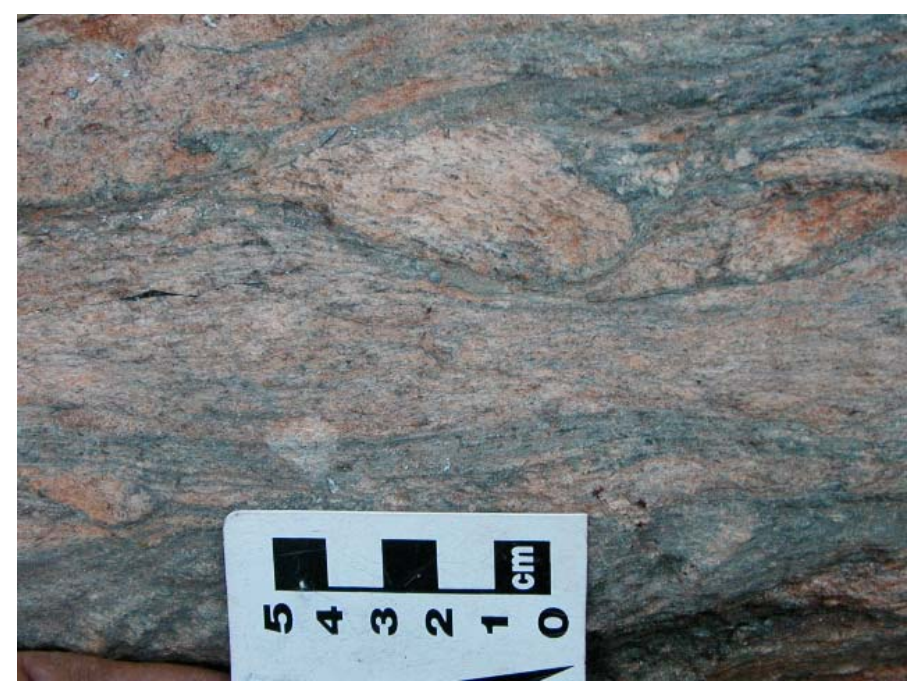

Figura 4.5: Micróliton composto pelo próprio milonito estirado e rotacionado em meio á matriz ultramilonítica (LBT-12).

O contato destes litotipos granodioríticos à norte com as rochas sienograníticas é tectônico, balizado através de zona de cisalhamento de baixo a médio âgulo, intensamente transpostas por sistemas verticalizados de natureza transcorrente.

\section{Sienogranitos miloníticos}

As rochas de composição sienograníticas distribuem-se na porção centro-sul da área estudada, em contato tectônico tanto com os litotipos granodioríticos como com as sequências metavulcanossedimentares da Formação Betara. De um modo geral, essas rochas apresentam cores cinza rosadas à rosadas e composição à base de feldspato potássico, quartzo, plagioclásio, biotita, sericita e clorita. Os estudos realizados por Kaulfuss (2001) caracterizam a presença de quartzo como ribbons (policristalinos com cristais exibindo extinção ondulante) finamente cristalizado na matriz e em sombras de pressão dos feldspatos. Os feldspatos em meio a matriz fina têm dimensões que atingem até $2 \mathrm{~mm}$, sendo normalmente fraturados internamente. Clorita, sericita e biotita definem a foliação protomilonítica na matriz. Os profiroclastos de feldspato apresentam-se estirados com tonalidades rosadas e atingem dimensões da ordem de 0,5-0,7 cm. Os baixos teores de $\mathrm{Rb}$ e $\mathrm{Zr}$, baixo $\mathrm{Sr}$ e o padrão dos elementos terras raras sugere uma relação com granitos tipo A (anorogênicos), sugestivos de processos distensivos (Kaulfuss, 2001). 
Rochas metabásicas, de granulação fina, normalmente muito intemperizadas, com cores que vão do avermelhado ao ocre, mostram processos de mistura de magmas (mixing/mingling) com os termos sienograníticos (figura 4.3).

Tais feições de mistura foram observadas em alguns afloramentos próximos à Pombas/ Conceição dos Correias (a exemplo do afloramento LBT-12) Os termos metabásicos encontram-se intensamente intemperizadas não possibilitando estudos petrográficos e/ou geoquímicos. Foram coletadas amostras estudos geocronológicos em zircão, uma vez que tal mineral é bastante resistente a processos de intemperismo.

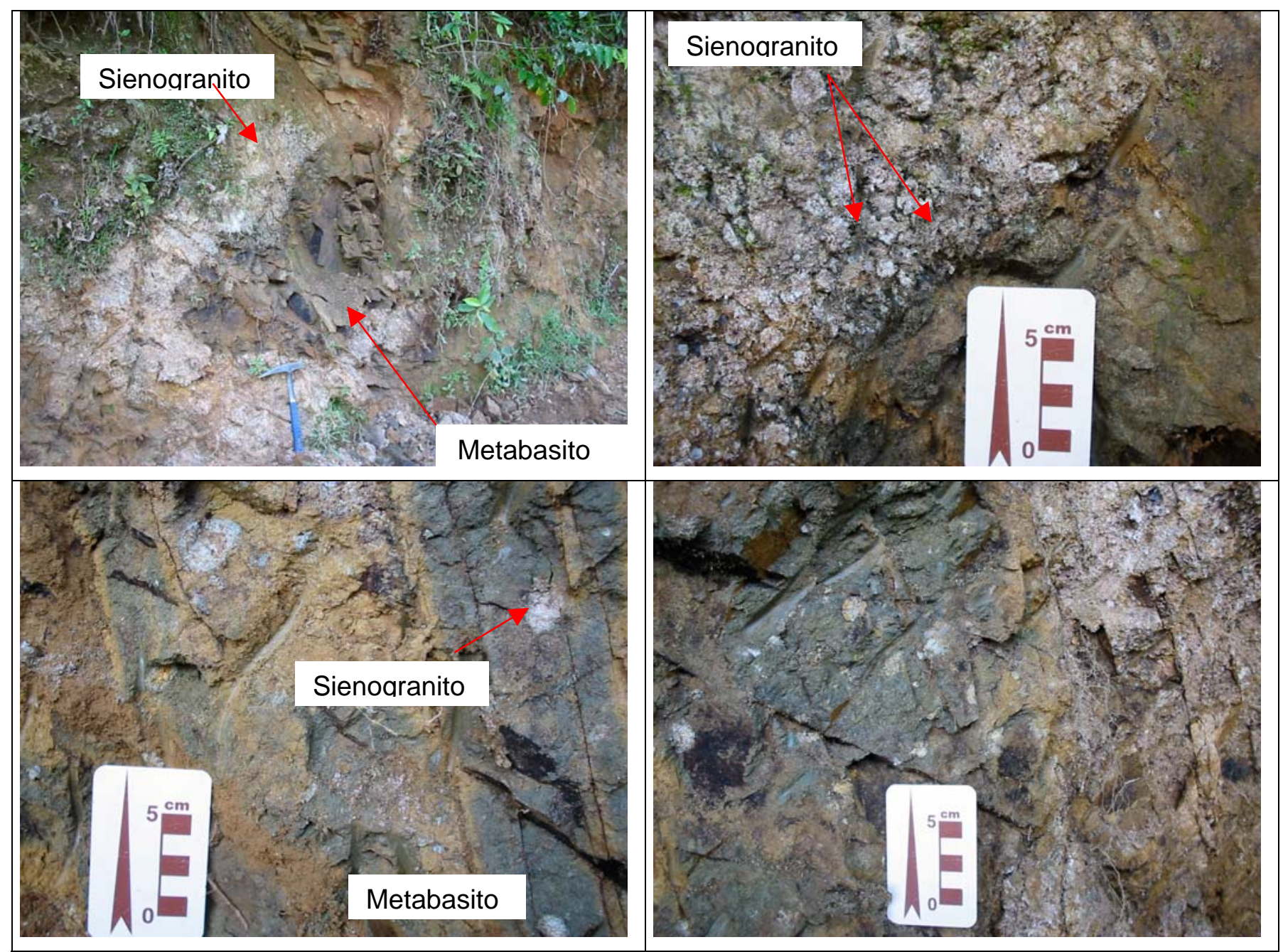

Figura 4.6: Feições de mistura de magmas (mixing/mingling) entre os metabasitos e sienogranitos do Núcleo do Betara (LBT-12). 1- Porção de metabasito "englobada" pelo sienogranito. 2- Feldspatos potássicos do sienogranito englobados no metabasito. 3- Pedaços de 
sienogranito englobados pelo metabasito. 4- Contato entre uma porção do metabasito e uma porção do sienogranito com porções do sienogranito englobadas no metabasito.

\section{Formação Betara}

\section{Sequência Metapsamítica (basal)}

Esta unidade é representada principalmente por pacotes métricos de quartzitos brancos de granulometria fina à média, relativamente puros e muitas vezes recristalizados. Intercalam-se pacotes, também métricos, de quartzitos micáceos (muscovita quartzitos), quartzo filitos, filitos grafitosos e filitos rítmicos). São comuns níveis ou mesmo pacotes métricos de quartzitos finos, homogêneos de coloração amarronada (denominados em campo de "quartzitos tipo doce de leite") que lembram meta-cherts. São frequentes impregnações de óxido de ferro, que conferem à estas rochas cores avermelhadas à amareladas.

As intercalações observadas (quartzitos finos à médios; muscovita quartzitos; quartzo filitos, filitos grafitosos. Destaca-se ainda feições de granodecrescência e a presença de estratificações cruzadas planares de pequeno á médio ângulo sugerindo ambientes deposicionais litorâneos. Estes litotipos quartzíticos sustentam a topografia à exemplo da Serra do Betara e do Morro do Descalvado.

\section{Sequência de Mármores, Cálciossilicáticas e Metamargas (intermediária)}

Está diretamente sobreposta às rochas quartzíticas, sendo representadas principalmente por afloramentos de mármores, por vezes silicosos, que ocorrem nas porções inferiores desta unidade. Apresentam tonalidades cinza-claras podendo ocorrer com bandamento, sugestivo da estratificação primária (S0) ou mesmo homogêneos (Figura 4.4). 


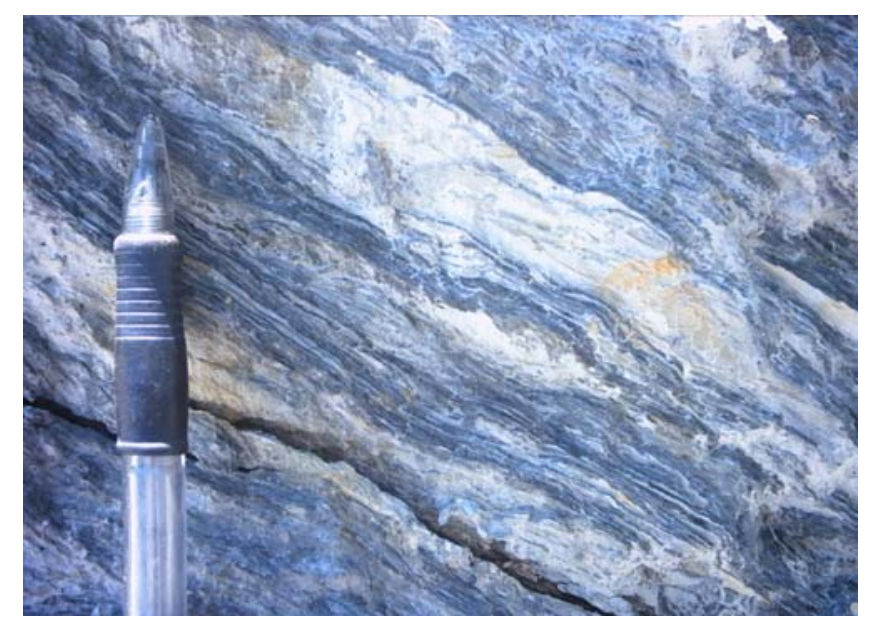

Figura 7.4 Mármore com bandamento sugestivo de estratificação primária (S0).

Estudos petrográficos realizados pela Mineropar (Piekarz, 1983) indicam uma textura granoblástica e uma mineralogia constituída essencialmente por calcita, quartzo e opacos. O quartzo ocorre intersticialmente, em cristais irregulares fraturados e com extinção ondulante.

Rochas calciossilicáticas intemperizadas intercalam-se aos mármores predominatemente nas porções superiores. São facilmente reconhecidas no campo por seu bandamento milimétrico a centimétrico com diferentes tonalidades constituindo níveis pelíticos à areno-pelíticos onde o conteúdo de carbonatos é variável (figura 4.5).

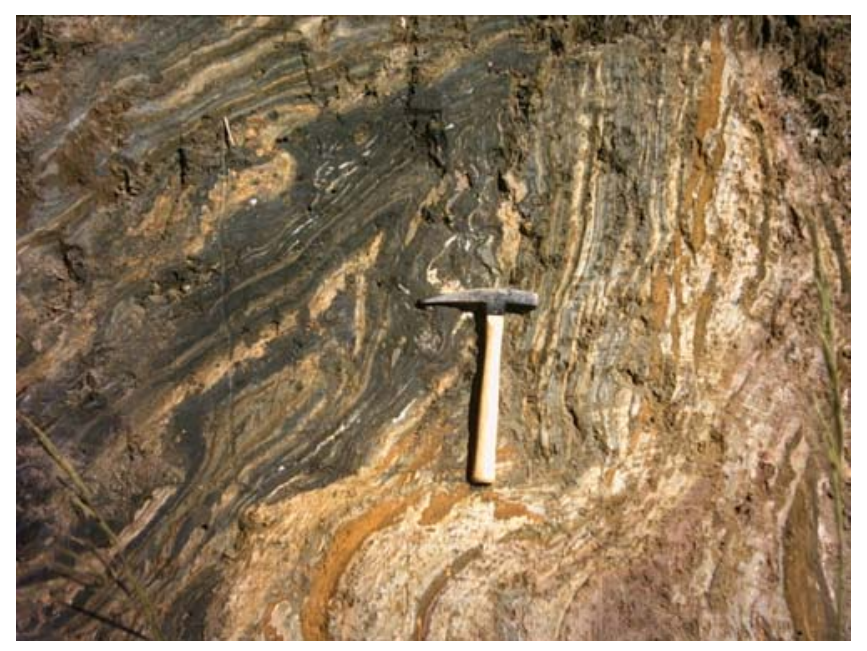

Figura 4.8: Dobras métricas em rocha cálcio-silicática com níveis pelíticos e areno pelíticos.

Filitos grafitosos, negros de granulometria fina à média ocorrem como pacotes métricos níveis centimétricos subordinados à esta sequência. 
Destaca-se nesta unidade a presença de rochas metavulcânicas com granulação fina, cor cinza clara constituídas principalmente por quartzo, feldspato, sericita e opacos, localmente contendo cavidades (vesículas) com material de preenchimento muito intemperizado. Foram classificadas por Coutinho (1983) como meta-felsitos (meta-traquitos) durante estudos realizados pelo Projeto Betara - Mineropar (Piekarz, 1983). De acordo com Coutinho (op cit.) estas rochas são constituídas por blastofenocristais de ortoclásio em matriz fina composta por cristais poligonais a ripiformes de ortoclásio, quartzo fino e plaquetas sub-orientadas de sericita. Nas cavidades cristalizam-se massas fibrorradiadas e concêntricas de variscita (fosfato de alumínio) e quartzo. Acessórios comuns são o rutilo em minúsculos bastonetes e cristais idiomórficos de magnetita parcialmente limonitizada.

Associam-se às rochas metavulcânicas corpos métricos de sulfeto e/ou formações ferríferas (figuras 4.6 e 4.7), bem como níveis de rochas silicáticas finas, por vezes impregnadas com óxidos de ferro, possíveis meta-cherts. Estes corpos apresentam coloração amarelada à ocre com porções escuras devido à presença de manganês. Estudos realizados pela Mineropar (1983) revelam anomalias significativas em $\mathrm{Cu}, \mathrm{Pb}$, e $\mathrm{Zn}$.

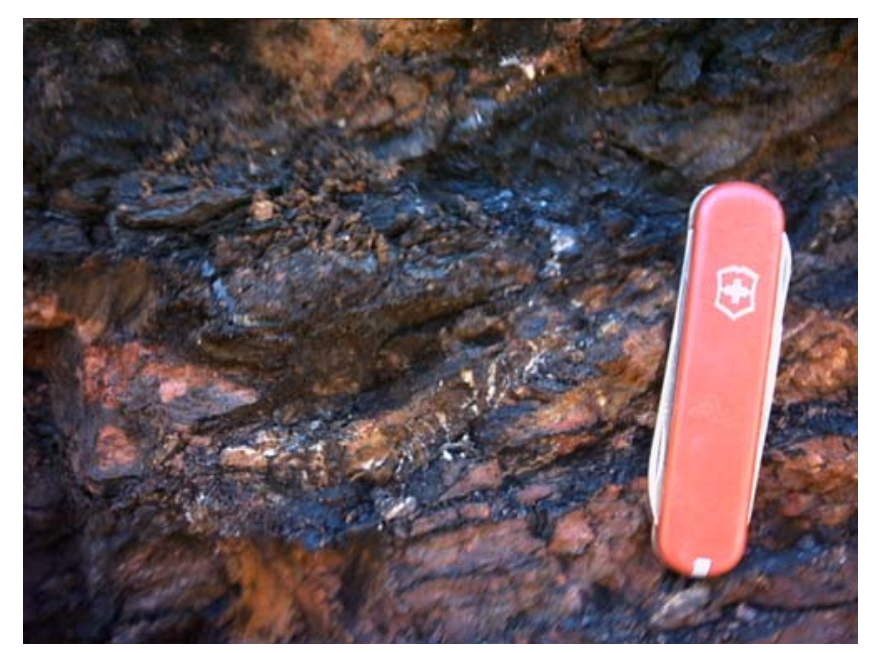

Figura 4.6: Formação ferrífera com concreções ferruginosas afloramento LBT-38 


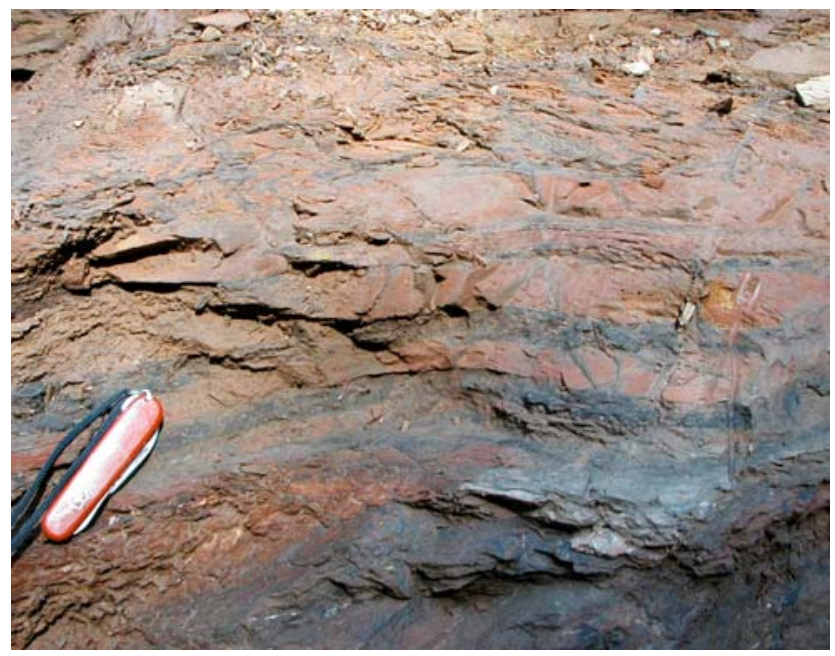

Figura 4.7: Formação ferrífera afloramento LBT-38

\section{Sequência Metapelítica (Superior)}

Nas porções superiores da Formação Betara predominam filitos com raras intercalações de rochas calciossilicáticas e quartzíticas. Apresentam-se por vezes homogêneos, por vezes bandados, tendo como mineralogia principal quartzo, serecitamuscovita, biotita, clorita e granada (localmente), e turmalina. Estas rochas encontramse invariavelmente intemperizadas, com tonalidades cinza-clara, amarelo mostarda e avermelhadas. O metamorfismo é de grau baixo, fácies xisto verde, zona da biotita (biotita-clorita-muscovita) e zona da granada (almandina-clorita-muscovita).

Corpos métricos de rochas metabásicas ocorrem intercalados concordantemente aos filitos, a exemplo dos afloramentos de número de campo LBT-7 e LBT-9 (setor NE) e LBT-17 e LBT-20 (setor sul). 


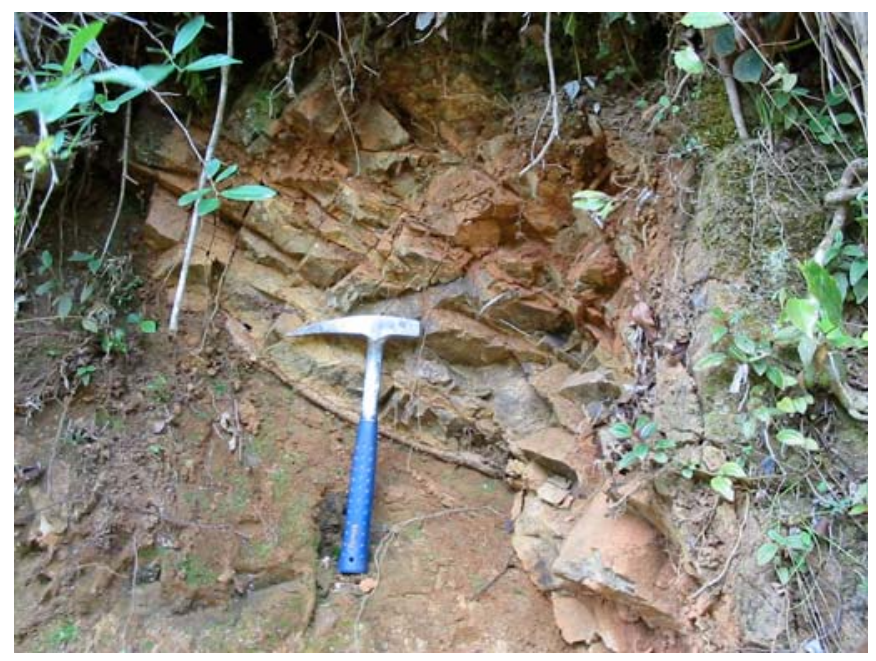

Figura 4.8: Afloramento de metabasitos (LBT-7).

As rochas metabásicas ocorrem normalmente intemperizadas, com corque ocre à cinza esverdeada, apresentando granulação fina á média (figura 4.8). O corpo que ocorre no setor NE tem granulação fina nas bordas gradando para média em direção ao centro. Apresenta uma foliação insipiente sub-paralela à observada nos filitos adjacentes destacada principalmente quando estas rochas encontram-se intemperizadas. Piekarz (1983) destaca no setor oriental a presença de fenocristais de minerais micáceos discordantes e aleatórios nas encaixantes denotando feições intrusivas destes corpos. Representam possíveis sills ou diques, constituídos principalmente por anfibólios da série da actinolita-tremolita, plagioclásio (parcial ou totalmente substituído por clinozoizita), minerais do grupo do epidoto e clorita.

\subsection{CARACTERÍSTICAS PETROGRÁFICAS}

O estudo petrográfico concentrou-se principalmente nas rochas metabásicas intercaladas aos metassedimentos da sequência superior da Formação Betara. No caso das rochas metabásicas o principal objetivo foi a caracterização mineralógica e textural, fundamentais aos estudos e interpretações geocronológicas. Nos metassedimentos tem grande importância a associação mineralógica, sua relação com as superfícies estruturais e o grau metamórfico presente. 
5.1 Aspectos Petrográficos da Sequência Metassedimentar

\subsubsection{Sequência Metapelítica Superior}

Estes litotipos apresentam, de modo geral, textura lepidoblástica, sendo constituídos mineralogicamente por sericita/muscovita e quartzo em proporções variáveis (figura 5.1). Subordinadamente ocorrem clorita, biotita, granada e opacos, notadamente em afloramentos próximos às zonas de cisalhamento. Variações texturais, caracterizadas pela alternância de níveis de granulação finna, média até grossa são comuns nestes litotipos. A muscovita presente em todas as lâminas observadas, define a foliação Sn. Esta pode ser de granulação fina e ocorrer bordejando grãos de quartzo (figura 5.2) ou mesmo com granulação grossa porfiroblástica (figura 5.3).

$\mathrm{O}$ quartzo normalmente apresenta granulação fina a média, contatos irregulares, e frequentes inclusões de zircão. A clorita quando presente é incolor, normalmente de granulação média, com cristais subédricos. Concentram-se em níveis milimétricos intercalados aos níveis de quartzo, definindo um plano de foliação (Sn) bem marcado.

A biotita, presente em amostras coletadas próximo a zonas de cisalhamento, ocorre como cristais subédricos, de granulação média ou grossa, neste caso como porfiroblasto. Observase muitas vezes, a presença de duas geraçãoes de biotita, uma paralela a foliação Sn e outra (tardia) truncando completamente esta foliação (figura 5.4).

A granada, quando presente mostra-se subédrica como porfirobastos em meio à matriz. A presença de foliação interna ao cristal de granada sugere seu desenvolvimento sin-tectônico (figura 5.6). 


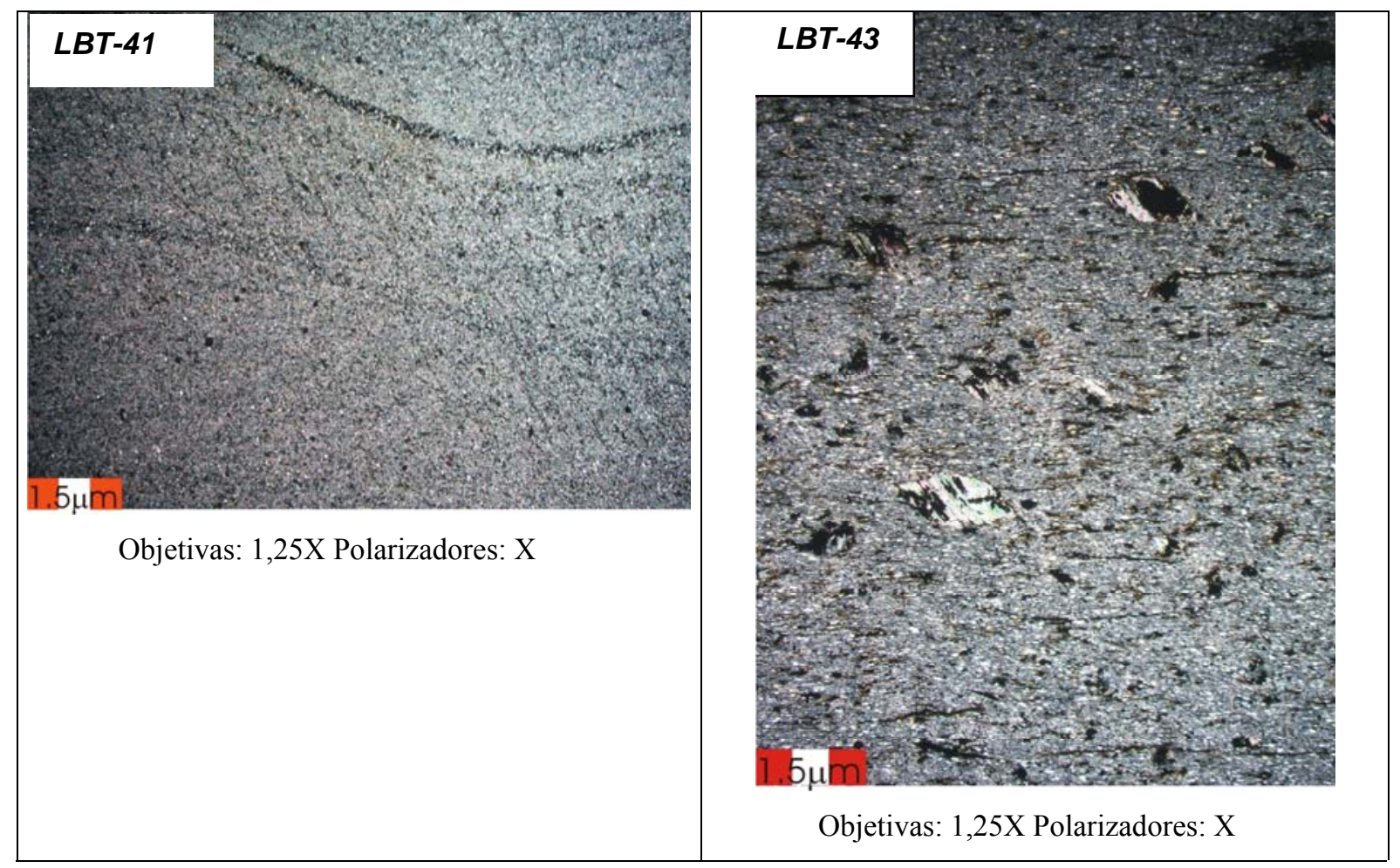

Figura 5.1: Texturas das amostras de muscovita filitos

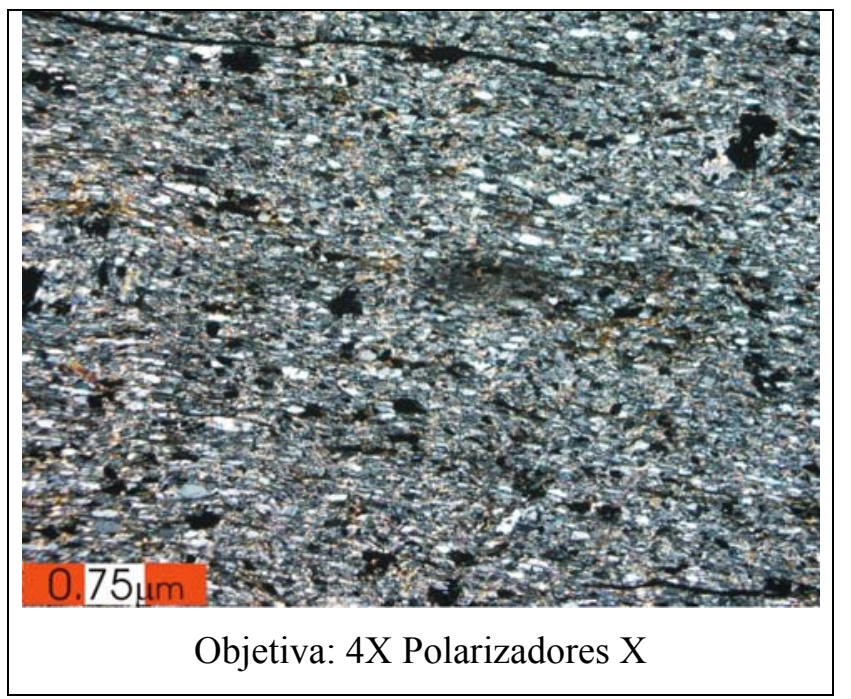

Figura 5.2: Quartzo e muscovita nos planos de foliação (LBT-43). 


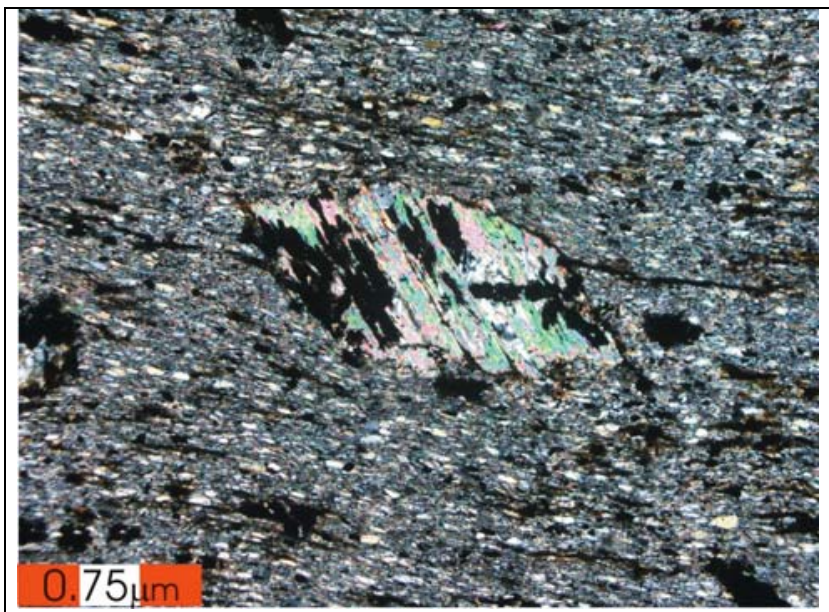

Objetiva: 4X Polarizadores: $\mathrm{X}$

Figura 5.3:Porfiroblasto de muscovita (LBT-43).

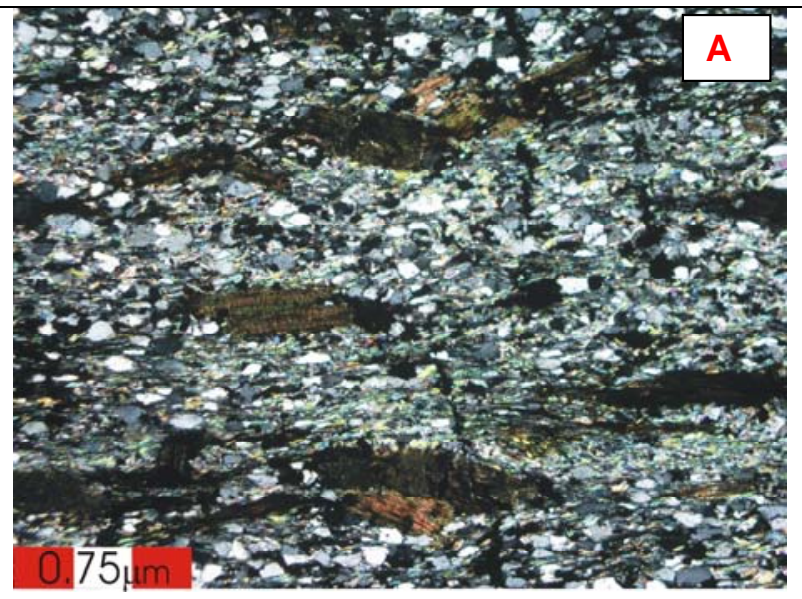

Objetivas: 4X Polarizadores: $\mathrm{X}$

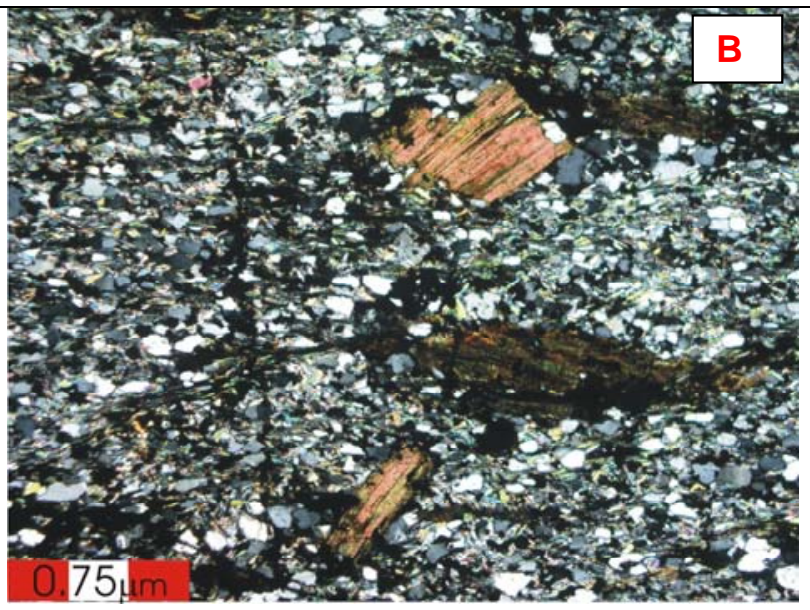

Objetivas: 4X Polarizadores: X

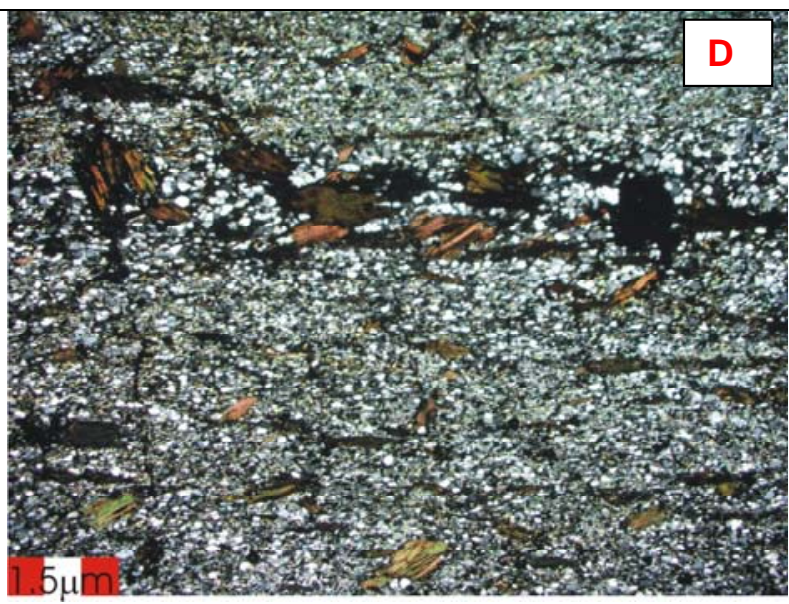

Objetivas: 1,25X Polarizadores: X 
Figura 5.4: Biotitas na amostra LBT-66 (A) Biotitas desenvolvidas paralelamente à Sn (B) e (C) Porfiroblastos de biotita truncando Sn. (D) Diferentes gerações de biotitas.

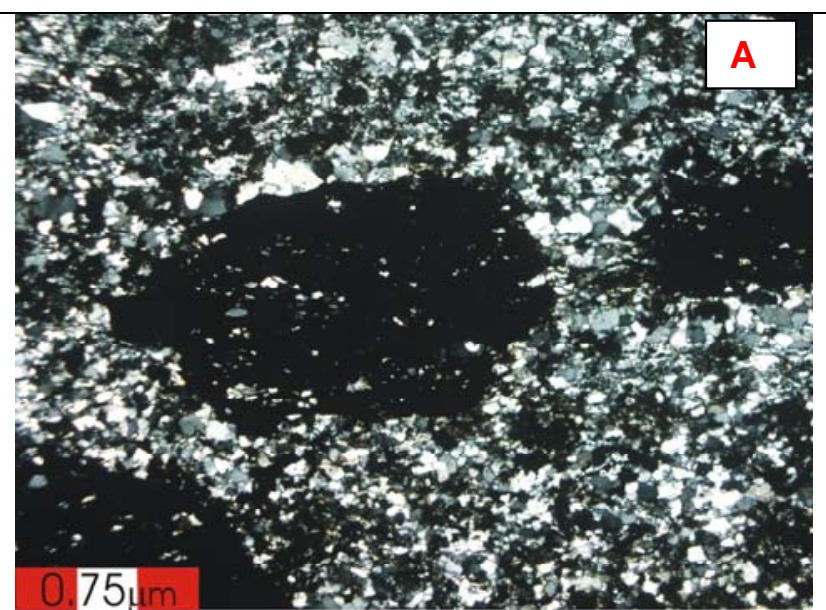

Objetivas: 4X Polarizadores: $\mathrm{X}$

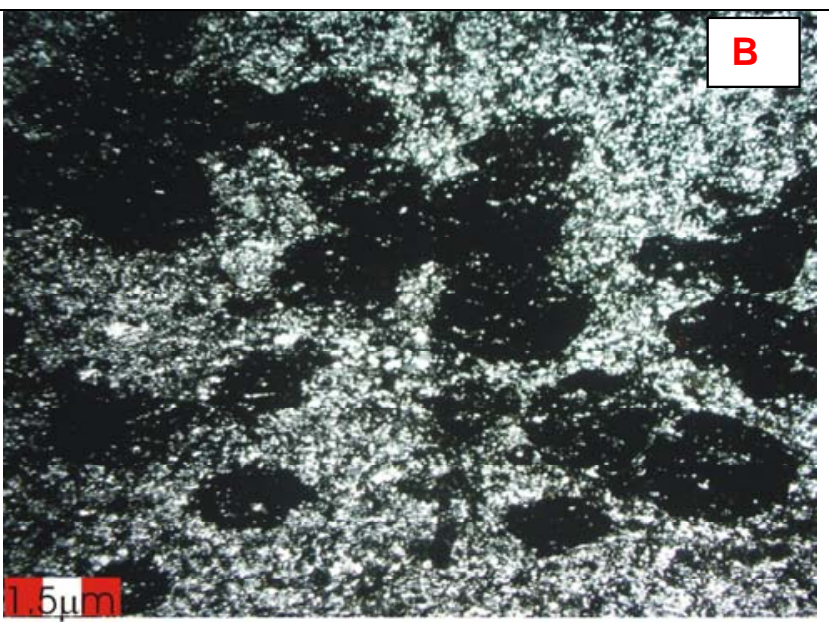

Objetivas: 1,25X Polarizadores: X

Figura 5.5: Porfiroblastos de granada na amostra LBT-44B (A) Sn interna ao porfiroblasto. (B) Porfiroblastos de granada e matriz.

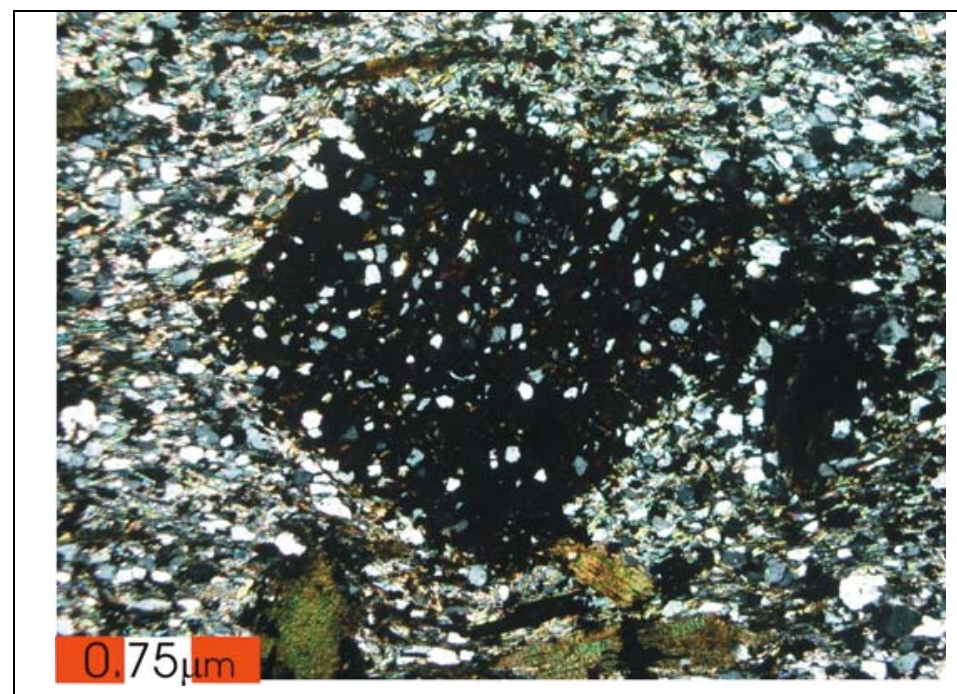

Objetivas: 4X Polarizadores: $\mathrm{X}$

Figura 5.6: Porfiroblasto de granada na amostra LBT-66.

\subsubsection{Sequência Meta-Carbonática (intermediária)}

Desta sequência foram observadas lâminas de calci-filitos que mostram uma mineralogia composta predominantemente por quartzo, dolomita, clorita magnesiana, tremolita, serpentina e titanita. De um modo geral as texturas são lepidoblásticas a granolepidoblásticas e a composição mineralógica alterna níveis ricos em quartzo, ricos em 
filissilicatos (muscovita e clorita) (figura 5.7) e ricos em dolomita caracterizando um bandamento composicional (S0). A foliação Sn, caracterizada principalmente pela orientação do quartzo e da muscovita, mostra-se paralela ao bandamento composicional e apresenta-se levemente crenulada.

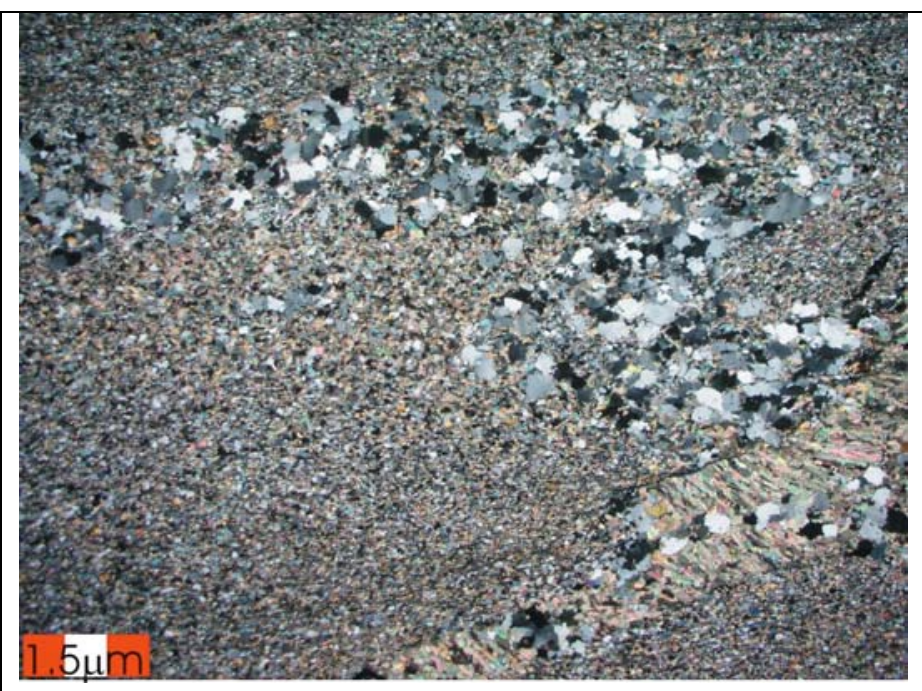

Objetivas: 1,25X Polarizadores: $\mathrm{X}$

Figura 5.7: Textura mostrando os níveis de quartzo e os níveis carbonáticosda rocha (LBT-63C).

A dolomita apresenta granulação média a grossa, destacando-se muitas vezes como porfiroblastos subédricos (figura 5.8)

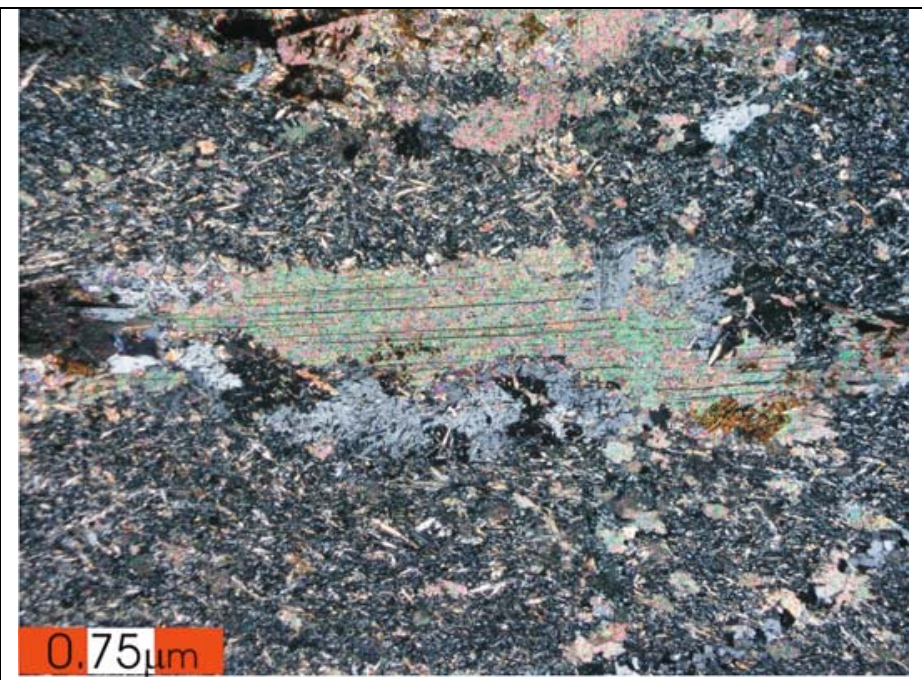

Objetivas: 4X Polarizadores: $\mathrm{X}$

Figura 5.8: Porfiroblasto de dolomita em meio à matriz de carbonato (LBT-67B).

A clorita magnesiana ocorre como cristais alongados de granulação fina à média em meio a matriz (figura 5.9). 


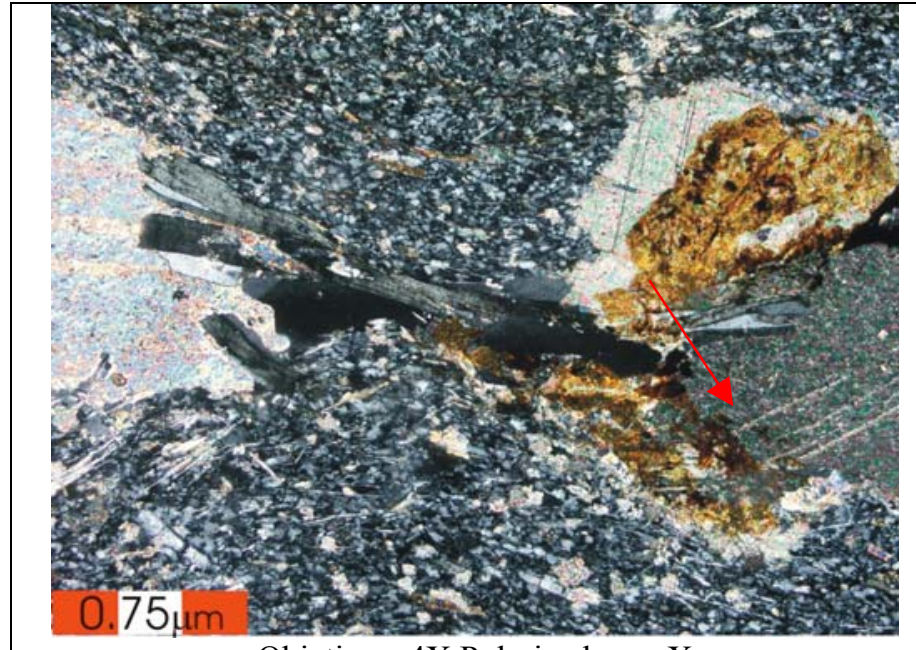

Objetivas: 4X Polarizadores: $\mathrm{X}$

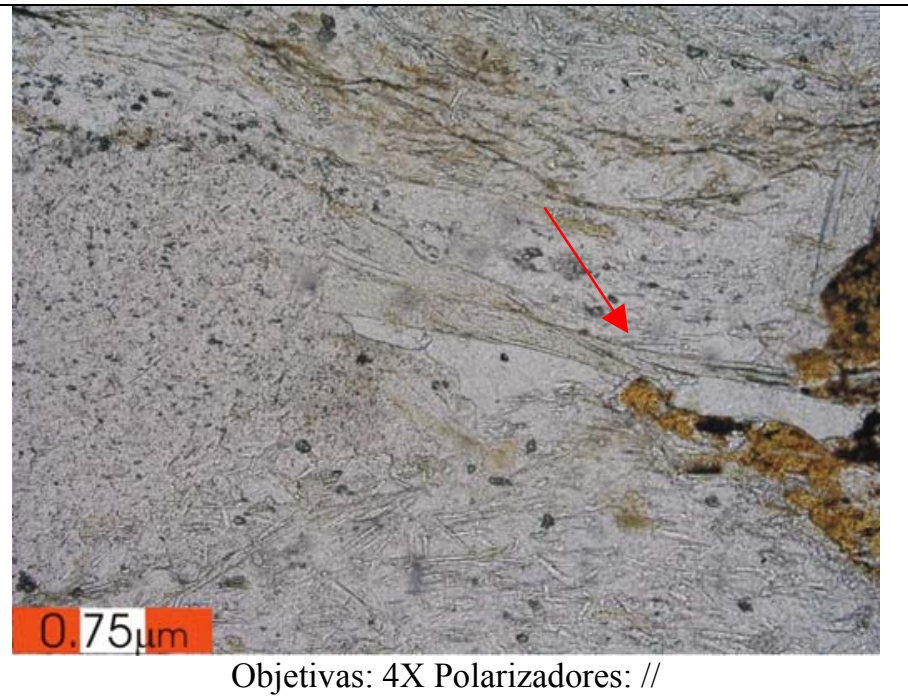

Objetivas: 4X Polarizadores: //

Figura 5.9: Clorita magnesiana (LBT-67B) polarizadores cruzados à esquerda e paralelos à direita.

A tremolita ocorre com granulação fina formando agregados com hábito fibroso (figura 5.10). A serpentina ocorre em fraturas com granulação fina.

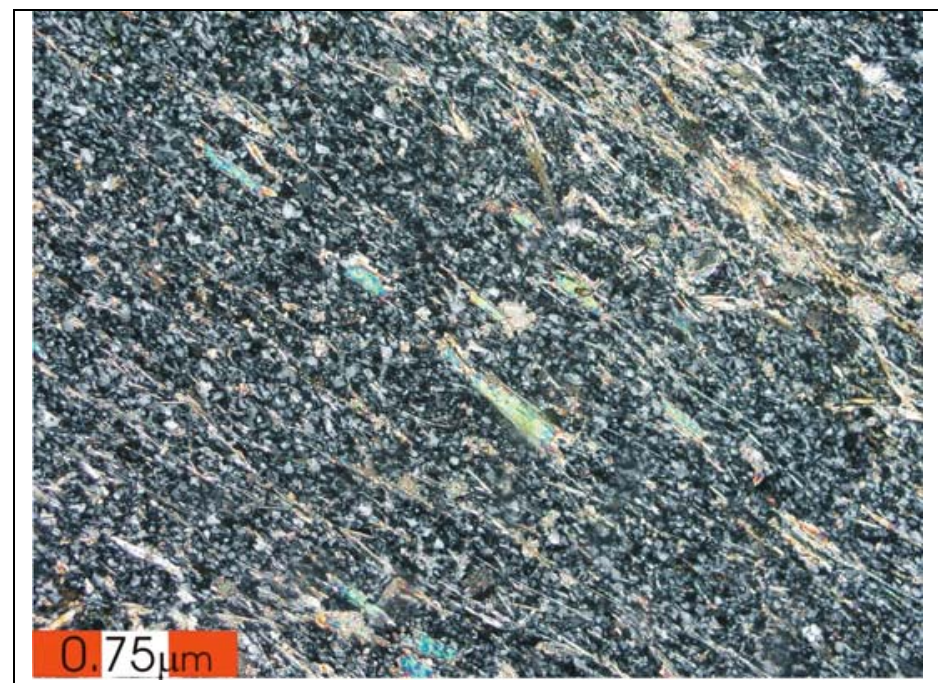

Objetivas: 4X Polarizadores: $\mathrm{X}$

Figura 5.10: Cristais de tremolita com hábito fibroso (LBT-67B) 


\subsection{Petrografia das Rochas Metabásicas}

$\mathrm{Na}$ descrição de campo destas rochas utilizou-se apenas o termo metabásica. Microscopicamente a nomenclatura teve por base a composição mineralógica e textural destas rochas, sempre utilizando-se dos minerais constituintes em maiores proporções seguido do termo fels. O termo fels foi adotado para rochas metamórficas de caráter básico que possuam uma textura determinada predominantemene por minerais prismáticos (diferente de uma textura xistosa determinada por filossilicatos). A mineralogia principal destas rochas consiste em: Actinolita, clinozoizita, clorita, albita, titanita e quartzo (em maiores prorporções para a actinolita e decrescendo em direção ao quartzo).Em algumas amostras a actinolita é o mineral predominante perfazendo mais de $80 \%$ da rocha (LBT17B). Porém há amostras com uma maior porcentagem de matriz de clinozoista, onde o anfibólio perfaz cerca de 55\% da amostra (LBT 20).

Assim de acordo com a porcentagem de cada um dos constituintes principais as amostras foram classificadas como:

Amostra LBT 7A:quartzo- clorita-albita-clinozoisita-actinolita fels

Amostras LBT 9A, LBT 9B, LBT 17A, LBT 17 B: quartzo-titanita-clinozoisitaclorita-actinolita fels

Amostra LBT 20: quartzo-titanita-clorita-clinozoisita-albita-actinolita fels 


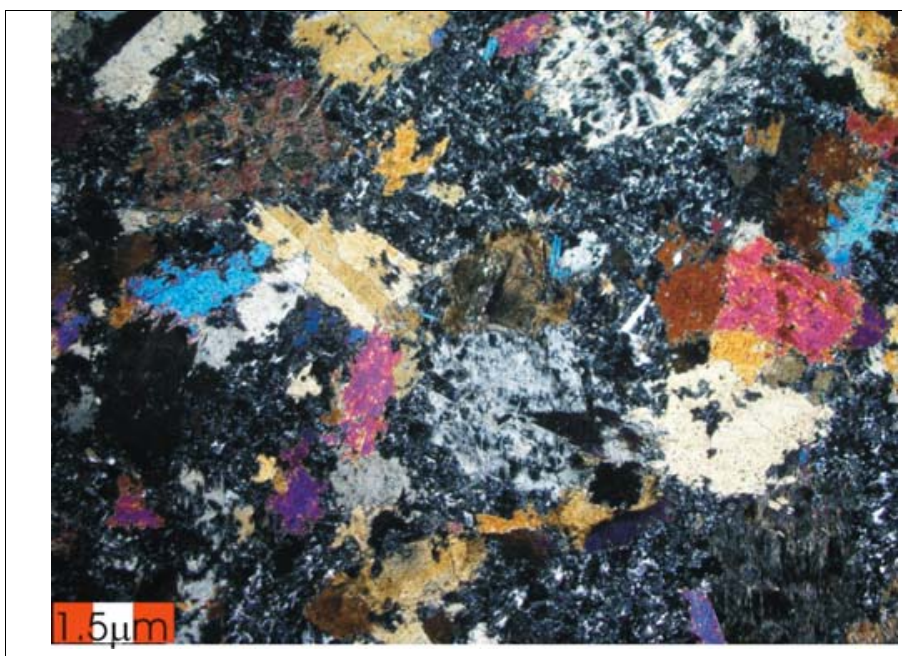

\section{LBT-7A}

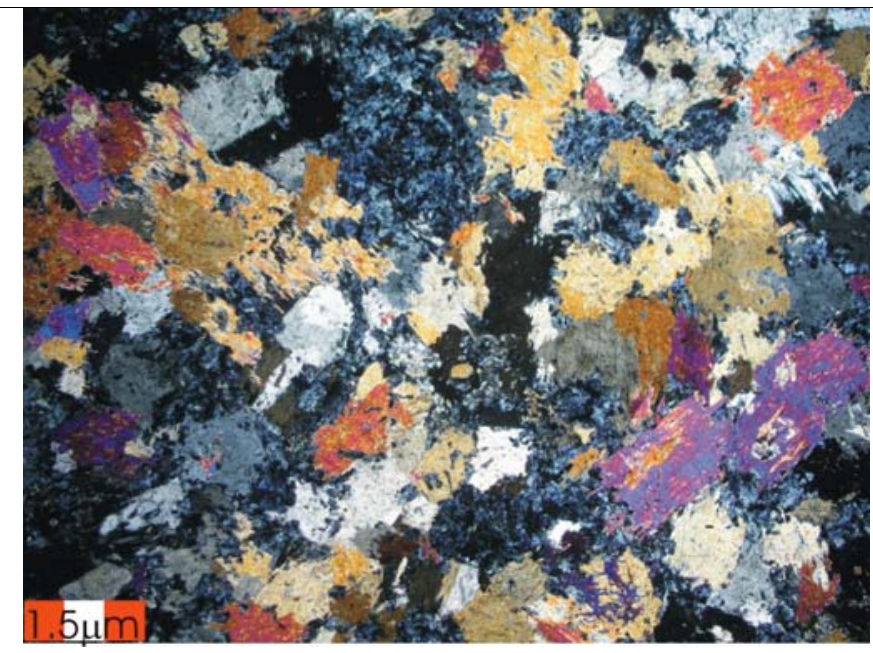

\section{LBT-9B}

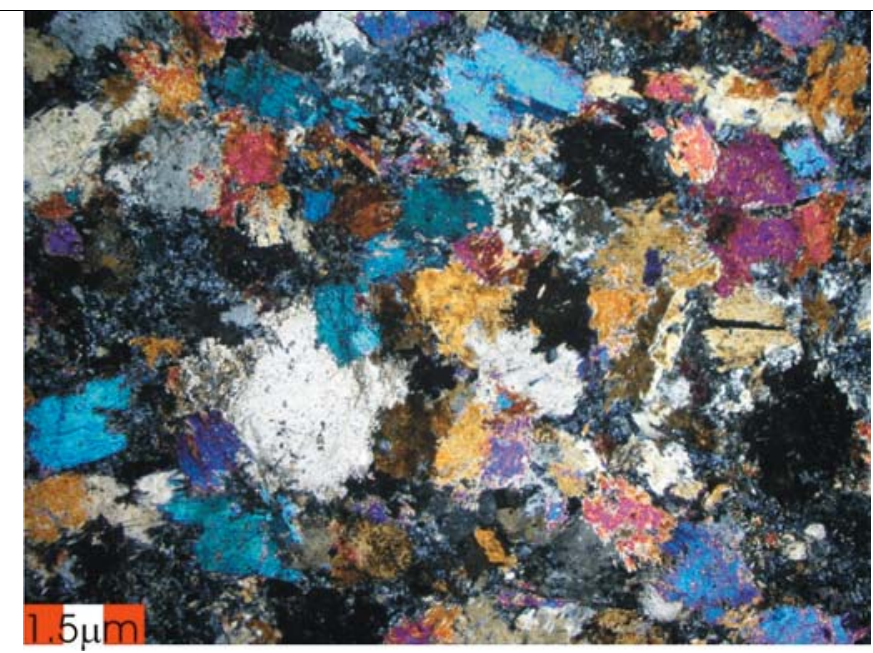

\section{LBT-17B}

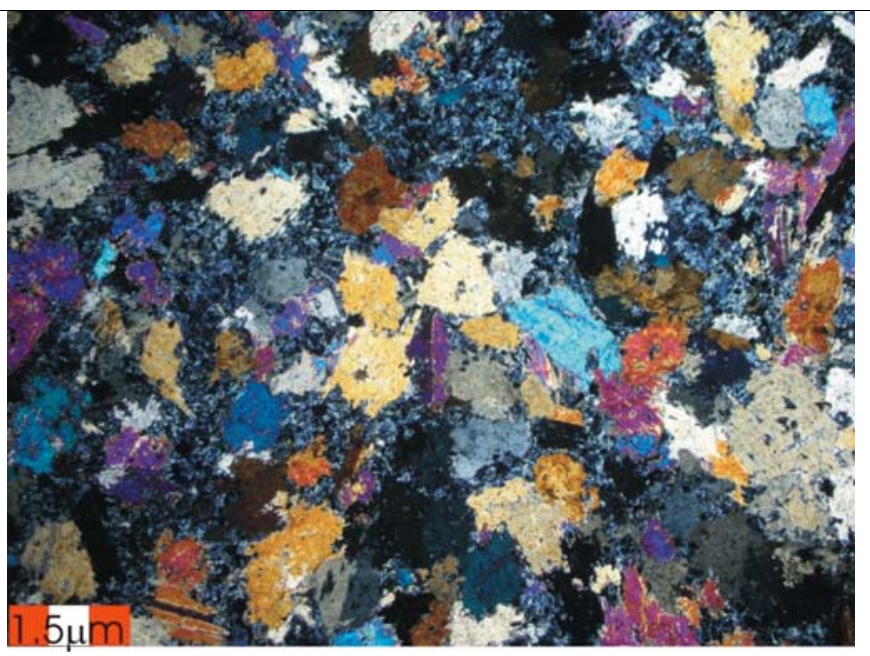

LBT-9A

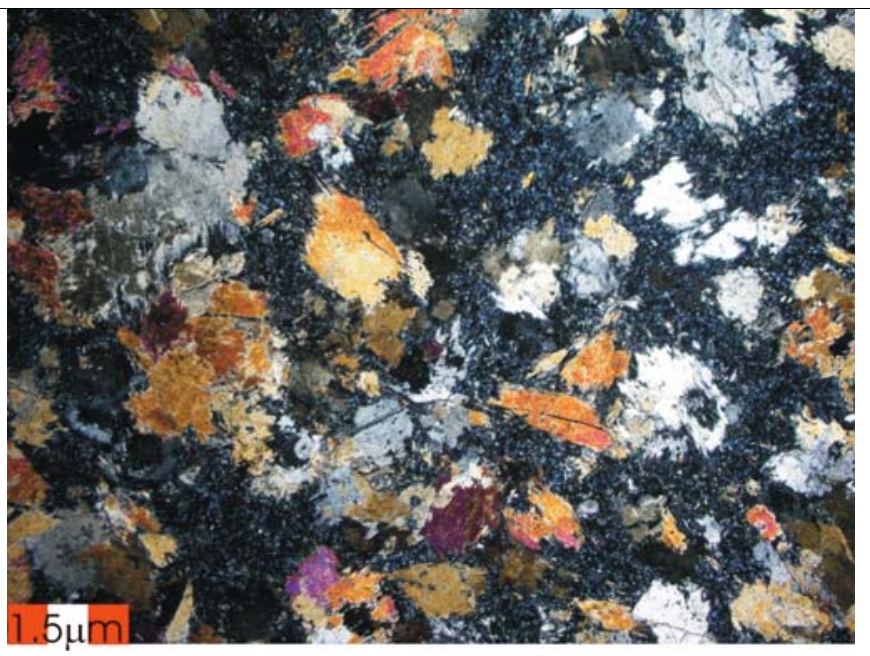

LBT-17A

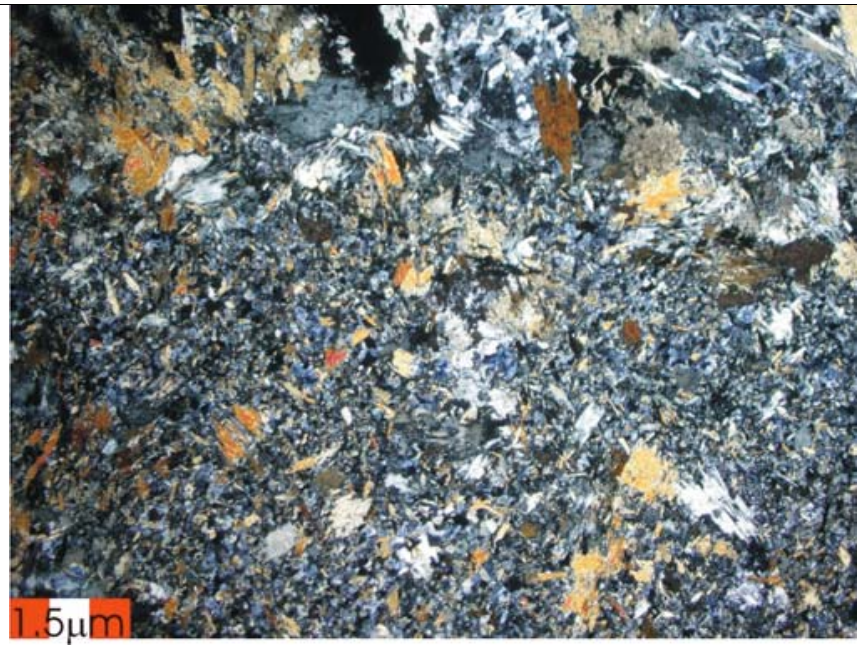

LBT-20 
Figura 5.11: Textura das diversas amostras. Todas as fotomicrografias acima foram tiradas com objetiva de $1,25 \mathrm{X}$ e nicóis cruzados.

\section{Mineralogia}

Actinolita:

A heterogeneidade textural é bastante evidente nos anfibólios que exibem um espectro morfológico/textural variado. Este mineral ocorre principalmente como pseudomorfos de piroxênio (Figura 5.12) com hábitos prismáticos curtos e, arranjados como blastofenocristais em meio a matriz. Em geral são subédricos com bordas corroídas e zonados. São comuns cristais de actinolita intercrescidos com clorita formando pseudomorfos prismáticos curtos que substituem a pigeonita (Figura 5.12). É possível recuperar nos anfibólios a geminação lamelar herdada dos piroxênios (Figura 5.13B).

São ainda observados microporfiroblastos alongados (Figura 5.14 A e B) deste mineral com terminações fibrosas e menos intemperizados que os descritos anteriormente. Ocorre ainda uma outra geração de anfibólios (mais fina) com cristais subédricos a euédricos com hábito acicular arranjados de maneira randômica em meio a matriz.

\section{Clorita:}

Ocorre junto à matriz formando concentrações junto a clinozoisita, bem com granulação fina à média intercrescida nos anfibólios (Figura 5.12).

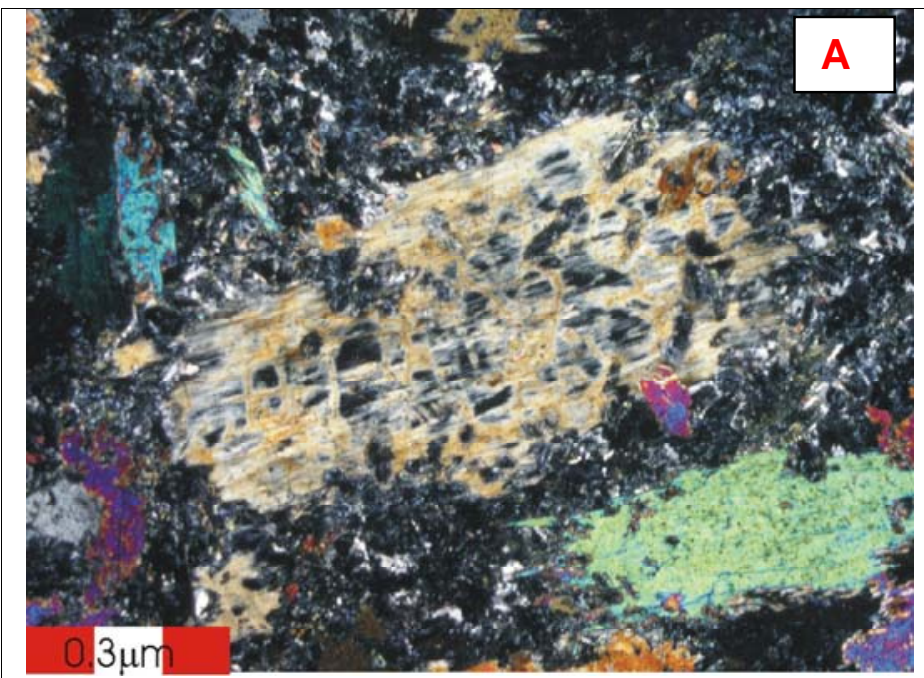

LBT-7A Objetiva: 1,25x2X Nicóis X

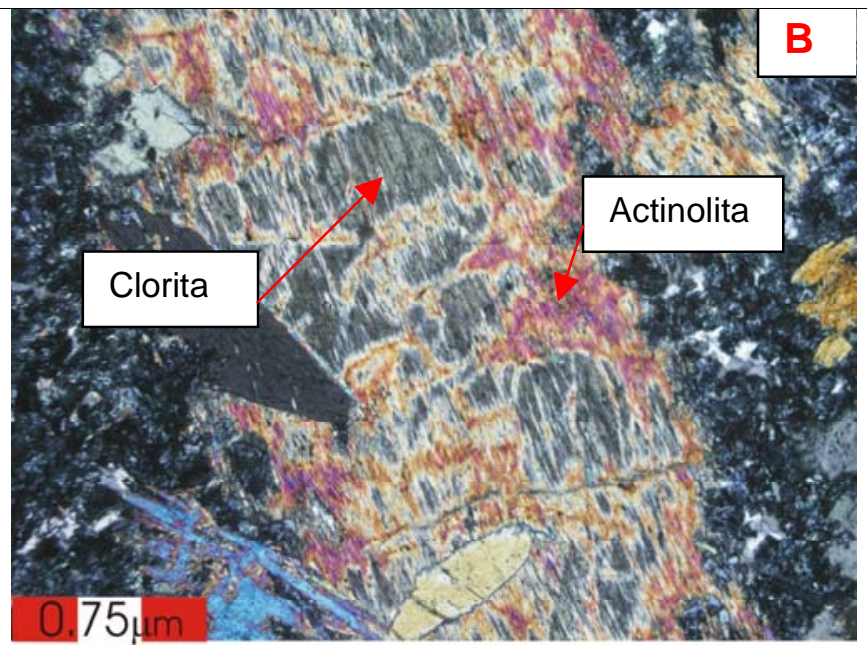

LBT-7A Objetiva: 4X Nicóis X 
Figura 5.12: Agregado de actinolita intercrescida com clorita (B) na forma de um prisma curto (A) substituindo a pigeonita (piroxênio sub-cálcico).

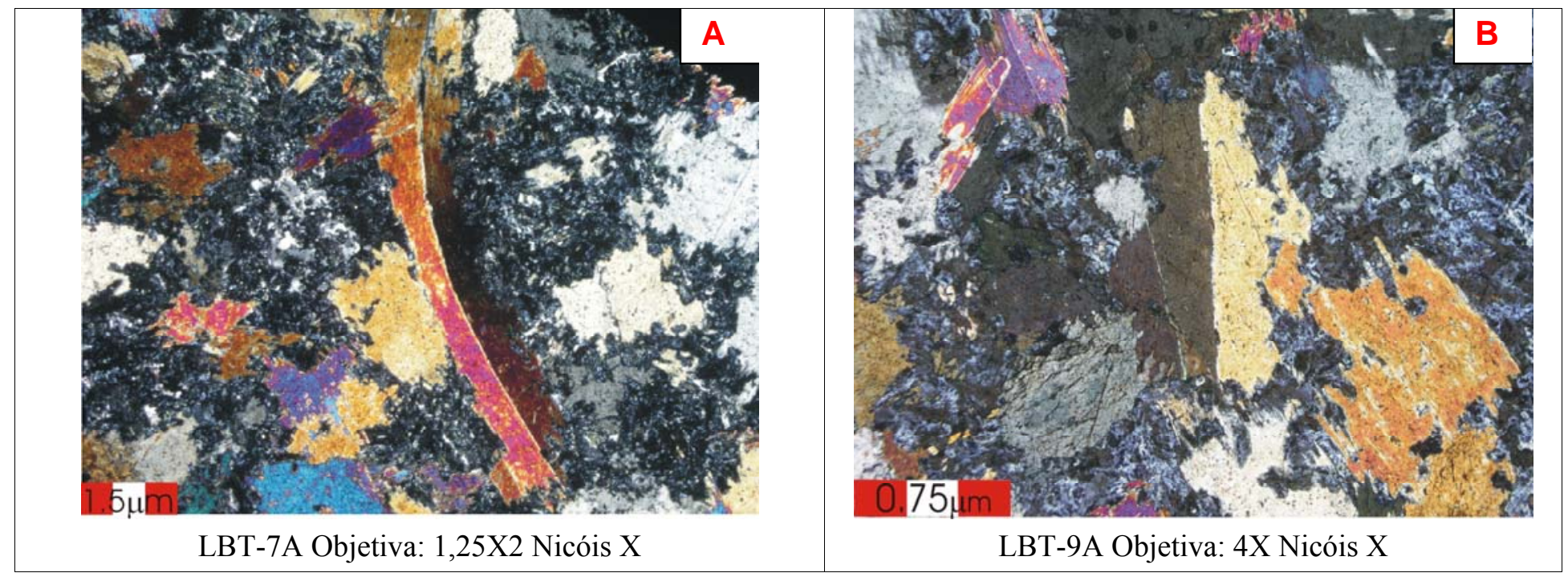

Figura 5.13: (A) Cristal de actinolita prismático flexionado (A), pseudomorfo do clinopiroxênio ígneo. Actinolita com geminação lamelar simples (B).

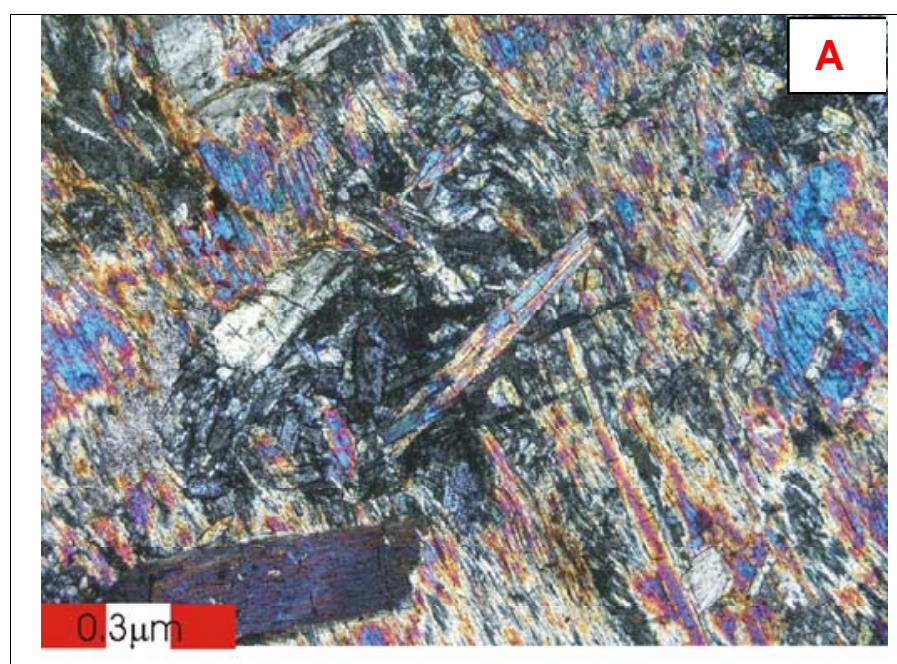

LBT-17B Objetiva: 10X Nicóis X

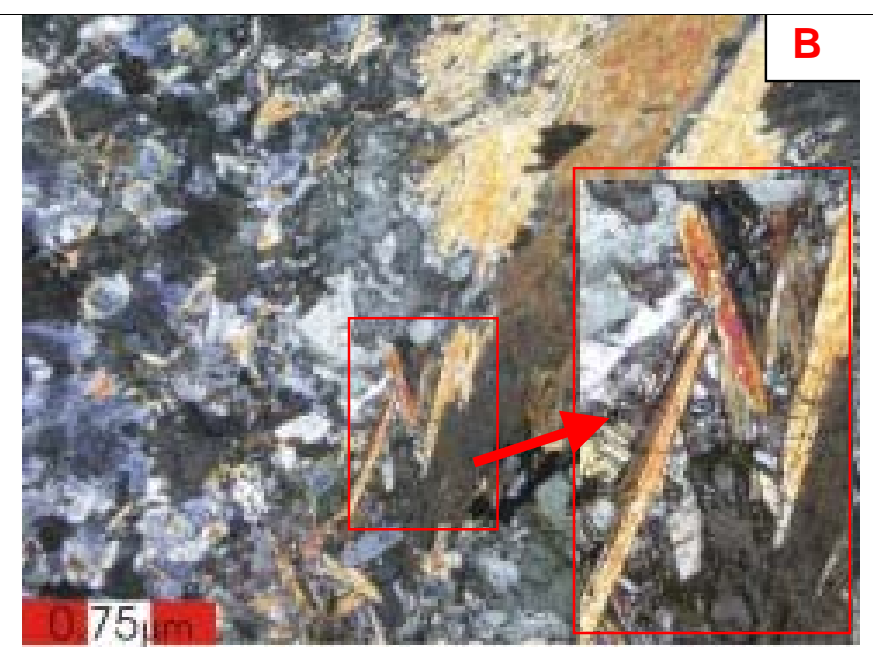

LBT-20 Objetiva: 4X Nicóis X

Figura 5.14: (A) e (B) Segunda geração de actinolita, com granulação fina e hábito acicular.

\section{Clinozoisita:}

Ocorre em agregados granulares finos em meio a matriz da rocha (Figura 5.16). Observa-se ainda pseudomorfos de plagioclásio totalmente substituídos por agregados de clinozoisita (Figura 5.13) em contato com as bordas dos prismas curtos de actinolita (pseudormorfos do piroxênio) sugerindo uma relação entre o piroxênio e o plagioclásio na paragênese original, que junto das texturas subofiticas pseudomorfizadas indicam a oigem ígnea da rocha. 
Titanita:

Ocorre em agregados granulares, com cristais anédricos a subédricos, provavelmente produtos da remobilização do titânio de minerais do protolito ígneo (piroxênios). Também ocorre como parte da matriz fina da rocha junto a clinozoisita.

\section{Quartzo:}

Ocorre com granulação fina em veios e concentrado junto às ocorrências de albita ou na forma de grãos intersticiais.

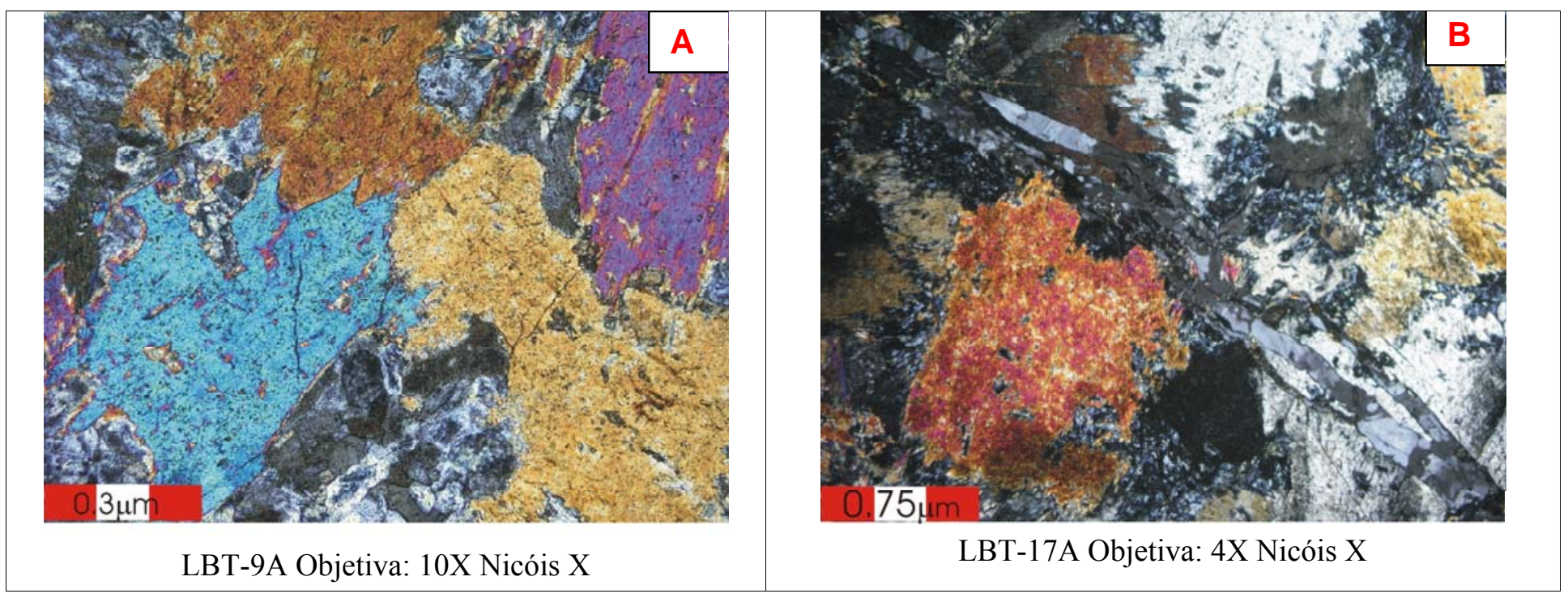

Figura 10.15: (A) Textura na interface entre a clinozoisita e cristais de anfibólio mostrando o contato "ripiforme" de cristais de plagioclásio já totalmente substituídos. (B) Veio de quartzo na amostra LBT 17A. 


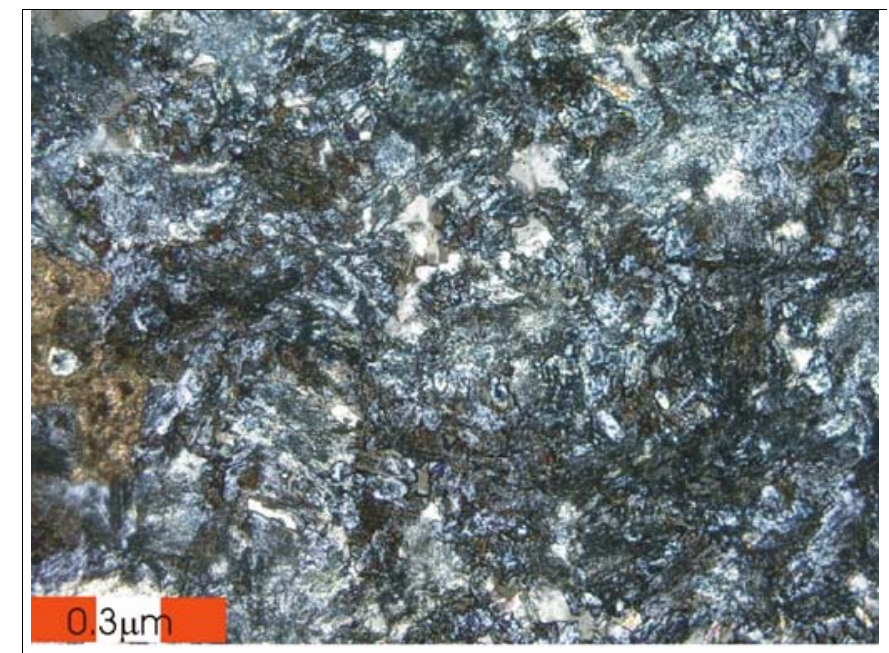

LBT-7A Objetiva: 10X Nicóis X

Figura 5.111: Clinozoisita em agregados granulares na matriz.

Albita:

Ocorre na forma de veios (Figura 5.17) ou mesmo como concentrados formando bolsões (Figura 5.18). Apresenta granulação média, cristais subédricos com hábito tabular curto. A forma de ocorrência deste mineral sugere uma remobilização de elementos químicos nestas rochas, evidenciada principalmente pela perda de álcalis (sódio e potássio) na forma de concentrações de albita (veios e bolsões isolados).

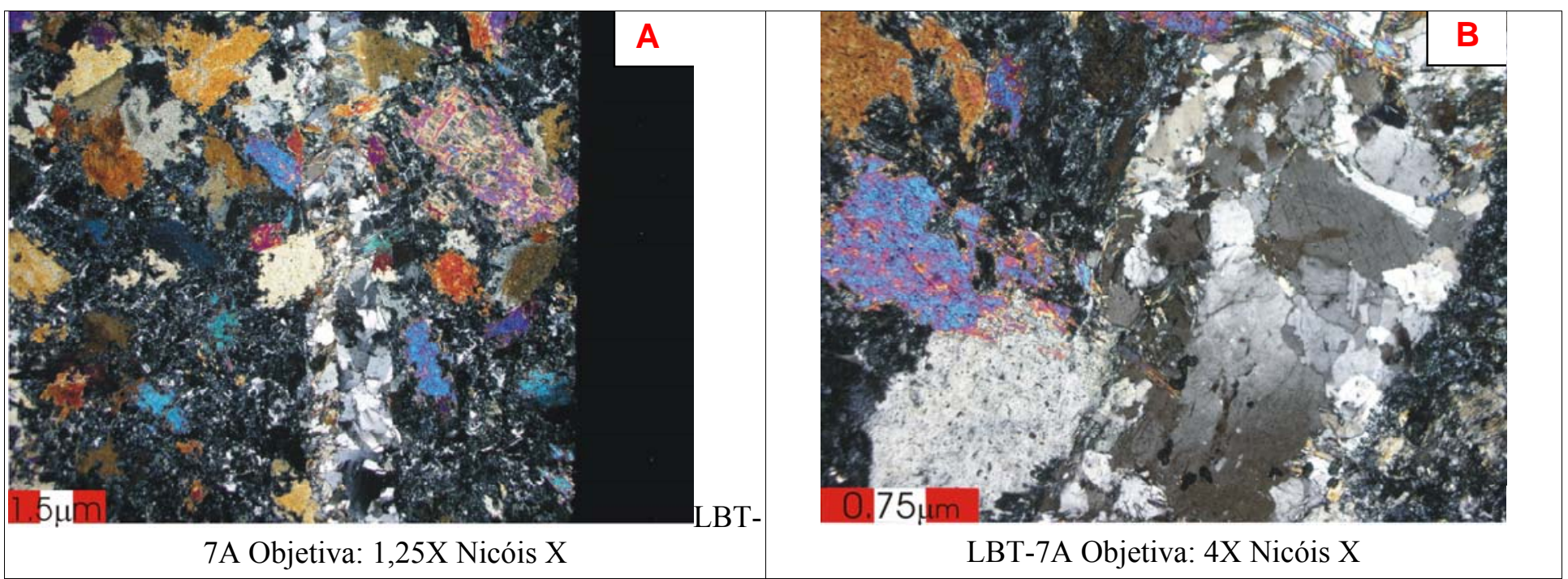

Figura 5.112:Amostra LBT-7A concentração de albitas na forma de um "veio. No restante da rocha a albita é praticamente ausente (A e B). 


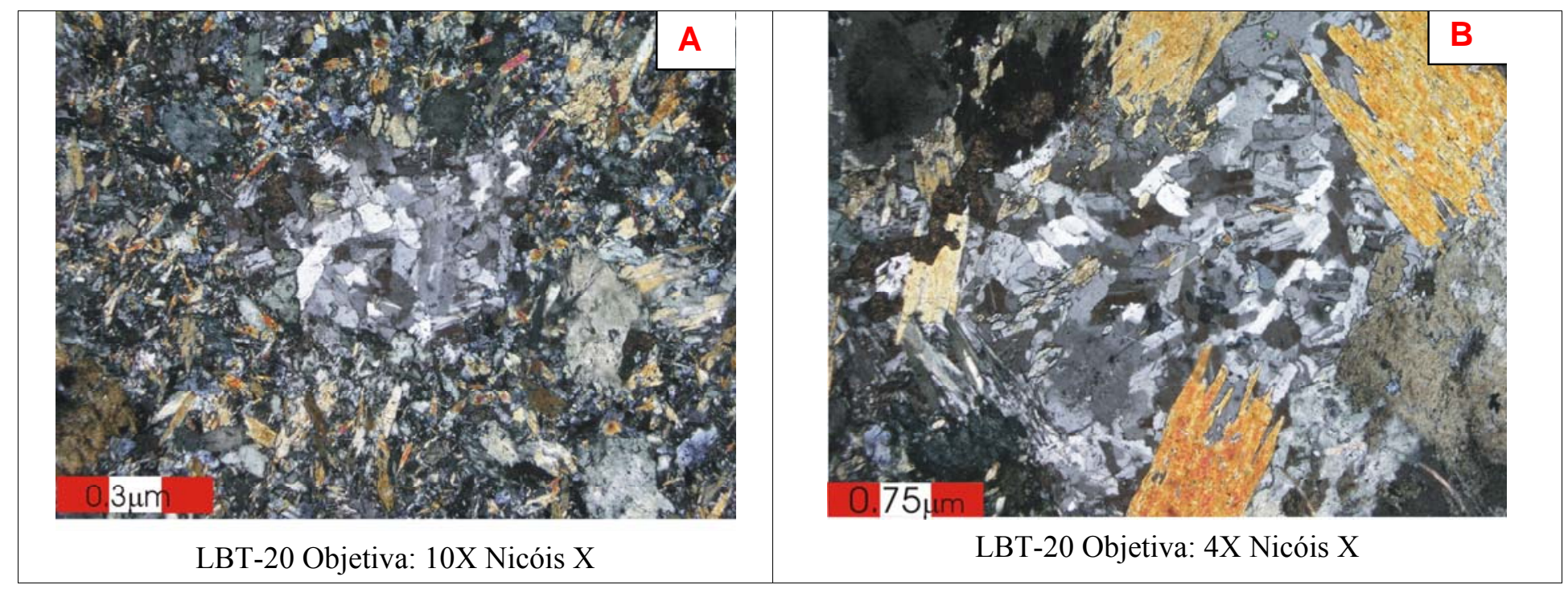

Figura 5.113: Amostra LBT-20 concentrações circulares de albita (A e B).

Turmalina:

Observada em uma lâmina como mineral acessório, com granulação fina a média (Figura $5.19)$.

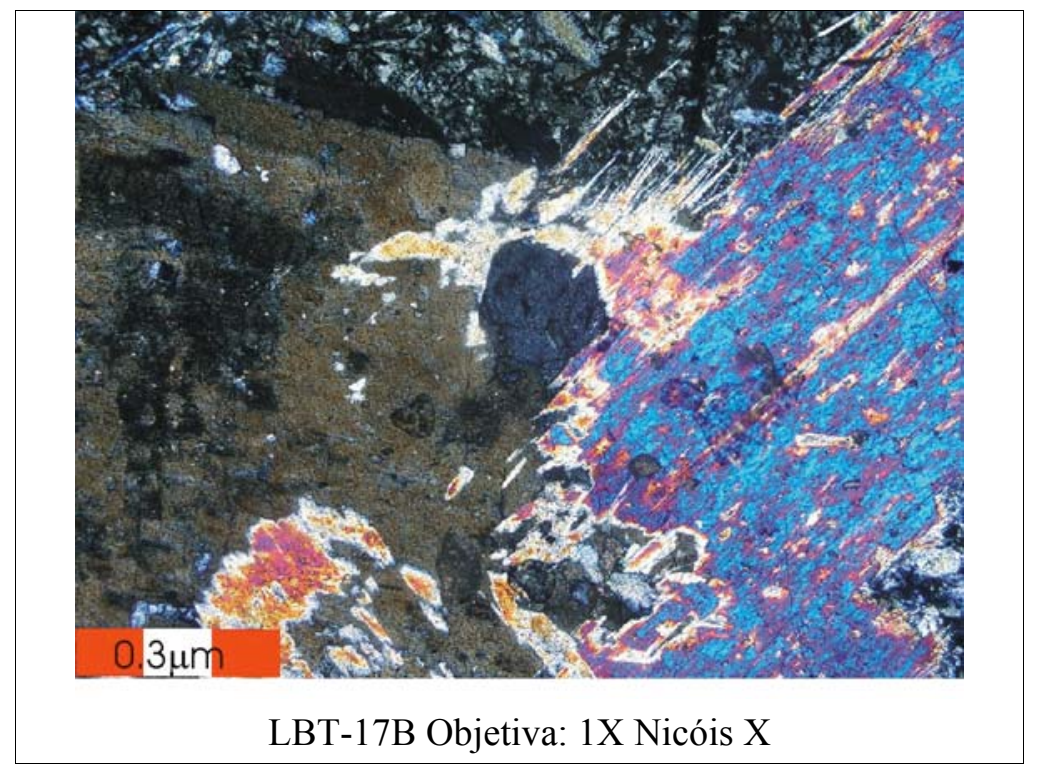

Figura 5.114: Seção basal de turmalina na amostra LBT-17B. 


\subsubsection{Metamorfismo das Rochas Metabásicas}

Al203

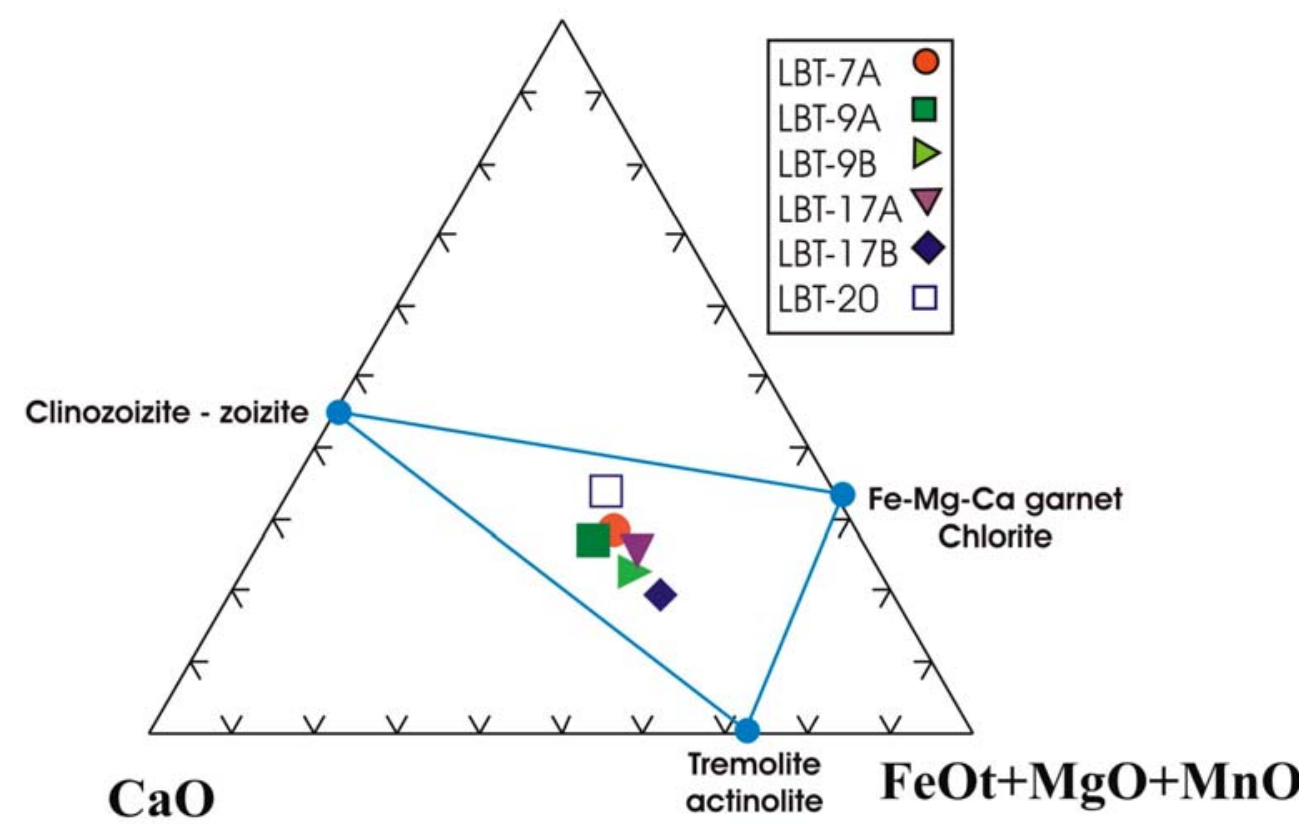

Figura 5.20: Diagrama ACF para as rochas metabásicas deste estudo. Os campos correspondentes às amostras foram obtidas com as procentagens dos óxidos maiores encontradas na tabela 6.1 .

As rochas metabásicas mostram importantes variações texturais com maior ou menor participação de minerais félsicos (clinozoisita e albita) e de componentes máficos. Além disso, a albita ocorre concentrada em bolsões ou veios, indicando processos de remobilização. As texturas das amostras evidenciam substituição,e as estruturas presentes sugerem uma deformação insipiente, indicativa de metamorfismo de baixo grau (fácies xisto verde zona da clorita).

Predominam texturas pseudomórficas granulares, preservando texturas reliquiares ofíticas à subofiticas, agregados de anfibólios organizados em primas curtos (piroxênios?) e concentrados de clinozoizita com hábitos tabulares, quando em contato com o anfibólio (plagioclásio?).

As observações realizadas, embora envolvendo um número reduzido de lãminas indicam que o arranjo químico-mineralógico original do protolito ígneo não foi preservado durante o processo metamórfico, mesmo de baixo grau. Isto impossibilitou análises geocronológicas $\mathrm{K}-\mathrm{Ar} /{ }^{40} \mathrm{Ar}-{ }^{39} \mathrm{Ar}$ de plagioclásios ou mesmo micas que poderiam fornecer informações relativas a formação/resfriamento destas rochas metabásicas.

As amostras estudadas registram etapas de rearranjo químico, observado através de variações na textura ora com maior ou menor participação de minerais félsicos (clinozoisita 
e albita). Pode-se ainda observar dentre as amostras uma maior ou menor participação de componentes máficos. Além disso, destacam-se minerais como a albita, que ocorre sempre formando bolsões ou veios caracterizando estruturas que não fazem parte da textura da rocha. As texturas evidenciam uma substituição por domínios composicionais, porém com pouca ou nenhuma deformação. Assim é possível interpretar que o arranjo químicomineralógico original do protolito ígneo não foi preservado durante o processo metamórfico (mesmo de baixo grau) com remobilização de alguns elementos químicos à exemplo do potássio. 


\subsection{ESTUDOS GEOQUÍMICOS}

Para realização das análises geoquímicas foram selecionadas as amostras com pouca, ou nenhuma alteração intempérica visível. Adicionalmente, em laboratório, as amostras foram preparadas de modo a utilizar apenas as porções mais centrais da amostra por meio de quebra manual.

Os estudos geoquímicos foram realizados em litotipos metabásicos intercalados aos filitos da Formação Betara, e tiveram como objetivo principal, complementar as observações petrográficas e fornecer informações adicionais sobre possíveis ambientes de formação destas rochas. Tais informações são fundamentais para a melhor caracterização tectônica desses terrenos. Adicionalmente, o padrão geoquímico obtido foi analisado conjuntamente com rochas similares que ocorrem no âmbito da Faixa Apiaí, estudadas por diferentes autores, a exemplo de Daitx (1996), Maniesi (1997), Frascá (1990), e Weber (2004).

As análises químicas foram realizadas em seis amostras distribuídas tanto no setor oriental (LBT- 7 e LBT-9), como o ocidental (LBT-17 e LBT-20) da região do Betara (mapa anexo). Tais análises envolveram elementos maiores ( $\mathrm{Si}, \mathrm{Al}, \mathrm{Mn}, \mathrm{Mg}, \mathrm{Ca}, \mathrm{Na}, \mathrm{K}$, Ti, P e Fe), elementos menores ( $\mathrm{Ba}, \mathrm{Ce}, \mathrm{Cl}, \mathrm{Co}, \mathrm{Cr}, \mathrm{Cu}, \mathrm{F}, \mathrm{Ga}, \mathrm{La}, \mathrm{Nb}, \mathrm{Nd}, \mathrm{Ni}, \mathrm{Pb}, \mathrm{Rb}, \mathrm{S}$, Sc, Sr, Th, U, V, Y, Zn e Zr) e elementos terras raras (ETR) conforme tabelas 5.1 e 5.2.

Os dados relativos aos elementos maiores foram recalculados em base anidra, subtraindo-se a porcentagem que representa a hidratação das amostras (perda ao fogo) tentando-se obter uma composição química mais próxima a composição estimada para o protolito ígneo antes do metamorfismo. Os diagramas que utilizam os elementos maiores foram confeccionados com os valores recalculados em base anidra. Os dados obtidos para os elementos traços e terras raras referem-se aos valores obtidos do laboratório, sem nenhum tipo de tratamento e encontram-se nas tabelas 5.1 e 5.2. 


\begin{tabular}{|c|c|c|c|c|c|c|}
\hline & LBT-07A & LBT-09A & LBT-09B & LBT-17A & LBT-17B & LBT-20 \\
\hline $\mathrm{SiO2}$ & 48,86 & 47,04 & 47,77 & 47,87 & 47,66 & 49,17 \\
\hline Al2O3 & 13,14 & 13,70 & 10,85 & 12,01 & 9,39 & 15,23 \\
\hline MgO & 9,83 & 11,23 & 13,44 & 11,89 & 13,92 & 7,81 \\
\hline $\mathrm{CaO}$ & 13,47 & 15,98 & 14,20 & 13,10 & 12,59 & 12,42 \\
\hline $\mathrm{FeO}(\mathrm{t})$ & 9,52 & 8,53 & 9,56 & 10,04 & 11,38 & 9,31 \\
\hline $\mathrm{Na} 2 \mathrm{O}$ & 1,43 & 0,34 & 0,29 & 0,79 & 0,36 & 2,42 \\
\hline $\mathrm{K} 2 \mathrm{O}$ & 0,11 & 0,03 & 0,02 & 0,12 & 0,11 & 0,27 \\
\hline MnO & 0,181 & 0,157 & 0,171 & 0,178 & 0,203 & 0,188 \\
\hline TiO2 & 0,675 & 0,402 & 0,500 & 0,646 & 0,677 & 0,712 \\
\hline P2O5 & 0,050 & 0,017 & 0,027 & 0,038 & 0,040 & 0,053 \\
\hline PF & 1,68 & 1,97 & 2,27 & 2,40 & 2,33 & 1,55 \\
\hline Total & 99,82 & 100,18 & 99,91 & 99,92 & 99,59 & 100,09 \\
\hline Ba & 22,6 & 8,16 & $9,1667,2$ & 67,2 & 48,5 & 57,8 \\
\hline Co & 56 & 53 & 65 & 60 & 74 & 53 \\
\hline $\mathrm{Cr}$ & 287 & 759 & 899 & 715 & 782 & 181 \\
\hline $\mathbf{C u}$ & 135 & 27 & 39 & 40 & 123 & 53 \\
\hline Cs & 0,20 & 0,07 & 0,08 & 0,20 & 0,17 & 0,34 \\
\hline $\mathrm{Ga}$ & 14 & 13 & 11 & 13 & 10 & 18 \\
\hline Hf & 0,57 & 0,27 & 0,35 & 0,39 & 0,47 & 0,45 \\
\hline Nb & 4 & 5 & 4 & 5 & 4 & 5 \\
\hline $\mathrm{Ni}$ & 114 & 183 & 229 & 231 & 276 & 94 \\
\hline $\mathbf{P b}$ & $<5$ & 8 & 23 & 16 & 9 & 8 \\
\hline $\mathbf{R b}$ & 5 & 3 & 2 & 5 & 5 & 7 \\
\hline Sc & 52 & 51 & 53 & 45 & 48 & 43 \\
\hline Sr & 132 & 169 & 140 & 266 & 196 & 181 \\
\hline Ta & 1,40 & 0,72 & 0,43 & 0,42 & 0,31 & 1,72 \\
\hline Th & 7 & 5 & 3 & 7 & 6 & 8 \\
\hline $\mathbf{U}$ & 0,05 & 0,02 & 0,02 & 0,04 & 0,03 & 0,04 \\
\hline V & 241 & 189 & 209 & 218 & 224 & 257 \\
\hline $\mathbf{Y}$ & 14 & 11 & 12 & 13 & 14 & 16 \\
\hline Zn & 57 & 49 & 56 & 80 & 89 & 66 \\
\hline $\mathrm{Zr}$ & 37 & 25 & 27 & 37 & 35 & 39 \\
\hline
\end{tabular}

Tabela 6.1: Elementos maiores, menores e traços: rochas metabásicas intercaladas nas sequências metavulcanossedimentares da Formação Betara. 


\begin{tabular}{|l|r|r|r|r|r|r|}
\hline & \multicolumn{1}{|c|}{ LBT-7A } & \multicolumn{1}{c|}{ LBT-9A } & \multicolumn{1}{c|}{ LBT-9B } & \multicolumn{1}{c|}{ LBT-17A } & \multicolumn{1}{c|}{ LBT-17B } & \multicolumn{1}{c|}{ LBT-20 } \\
\hline $\mathrm{La}$ & 2,14 & 1,63 & 2,29 & 2,09 & 1,51 & 3,27 \\
\hline $\mathrm{Ce}$ & 5,22 & 2,75 & 3,29 & 4,85 & 4,04 & 6,56 \\
\hline $\mathrm{Pr}$ & 0,83 & 0,60 & 0,84 & 0,80 & 0,69 & 1,02 \\
\hline $\mathrm{Nd}$ & 4,44 & 3,19 & 4,39 & 4,31 & 3,87 & 5,31 \\
\hline $\mathrm{Sm}$ & 1,52 & 1,16 & 1,48 & 1,51 & 1,42 & 1,74 \\
\hline $\mathrm{Eu}$ & 0,59 & 0,47 & 0,54 & 0,63 & 0,43 & 0,85 \\
\hline $\mathrm{Gd}$ & 1,95 & 1,31 & 1,83 & 1,93 & 1,81 & 2,15 \\
\hline $\mathrm{Tb}$ & 0,32 & 0,23 & 0,30 & 0,32 & 0,31 & 0,37 \\
\hline $\mathrm{Dy}$ & 2,08 & 1,47 & 1,90 & 2,02 & 2,00 & 2,39 \\
\hline $\mathrm{Ho}$ & 0,48 & 0,33 & 0,43 & 0,46 & 0,45 & 0,54 \\
\hline $\mathrm{Er}$ & 1,38 & 0,92 & 1,19 & 1,31 & 1,26 & 1,58 \\
\hline $\mathrm{Tm}$ & 0,20 & 0,13 & 0,17 & 0,19 & 0,18 & 0,22 \\
\hline $\mathrm{Yb}$ & 1,25 & 0,84 & 1,04 & 1,19 & 1,11 & 1,41 \\
\hline $\mathrm{Lu}$ & 0,17 & 0,11 & 0,14 & 0,15 & 0,15 & 0,18 \\
\hline
\end{tabular}

Tabela 6.2: Elementos terras raras: rochas metabásicas intercaladas nas sequências metavulcanossedimentares da Formação Betara.

\subsection{Comportamento dos Elementos - Diagramas de Variação}

\subsubsection{Elementos Maiores, Menores e Traços}

Os dados químicos envolvendo os elementos maiores, menores e traços foram analisados em diagramas binários (figuras 5.1 e 5.2) utilizando o $\mathrm{MgO}$ (no eixo das abcissas) versus $\mathrm{SiO}_{2}, \mathrm{Al}_{2} \mathrm{O}_{3}, \mathrm{MnO}$, $\mathrm{CaO}, \mathrm{Na}_{2} \mathrm{O}, \mathrm{K} 2 \mathrm{O}, \mathrm{TiO}_{2}, \mathrm{P}_{2} \mathrm{O}_{5}$ e $\mathrm{FeO}_{\mathrm{t}}$ (eixo das ordenadas). Nestes diagramas têm-se uma visão conjunta do quimismo destas rochas metabásicas, observando-se variações composicionais relativamente significativas nos teores dos óxidos, incluindo o $\mathrm{MgO}$.

Uma primeira análise destes dados químicos (tabelas 5.1 e 5.2 e figuras 5.7 e 5.8 ) verifica-se em relação aos teores de $\mathrm{SiO}_{2}$, uma predominância do caráter básico $\left(45 \%<\mathrm{SiO}_{2}<53 \%\right)$ para as rochas deste estudo. O empobrecimento em álcalis para estas rochas fica bem evidenciado nos diagramas onde estão plotados o $\mathrm{Na} 2 \mathrm{O}$ e o $\mathrm{K} 2 \mathrm{O}$ contra o $\mathrm{MgO}$ (exceção à amostra LBT-20).

Alguns elementos apresentam comportamento geoquímico bastante coerente em relação ao $\mathrm{MgO}$ variando de forma crescente, decrescente em relação ao $\mathrm{MgO}$, ou mesmo permanecendo relativamente constantes. Os elementos que apresentam correlação positiva em relação ao $\mathrm{MgO}$ são: FeOt, Cr e Co. Os elementos que apresentam correlação negativa em relação ao $\mathrm{MgO}$ são: $\mathrm{A} 12 \mathrm{O} 3, \mathrm{Ni}, \mathrm{Ga}$ e Na2O. Já o TiO2, P2O5, MnO, CaO e SiO2 permanecem relativamente constantes em relação ao $\mathrm{MgO}$. Os demais elementos ( $\mathrm{V}$, $\mathrm{K} 2 \mathrm{O}, \mathrm{Sr}, \mathrm{Zn}, \mathrm{Y}$ e Zr) apresentam-se dispersos no diagrama. 


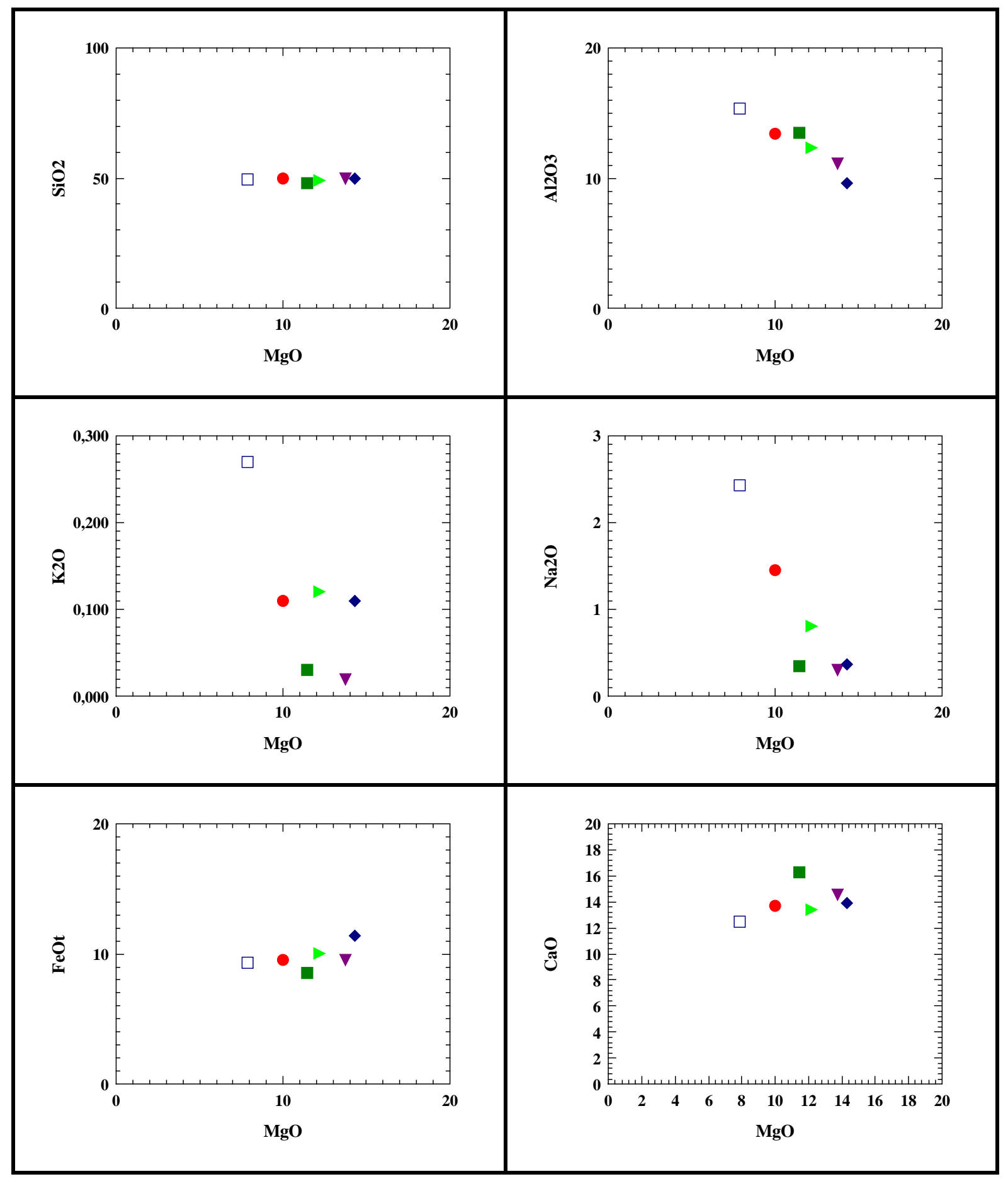




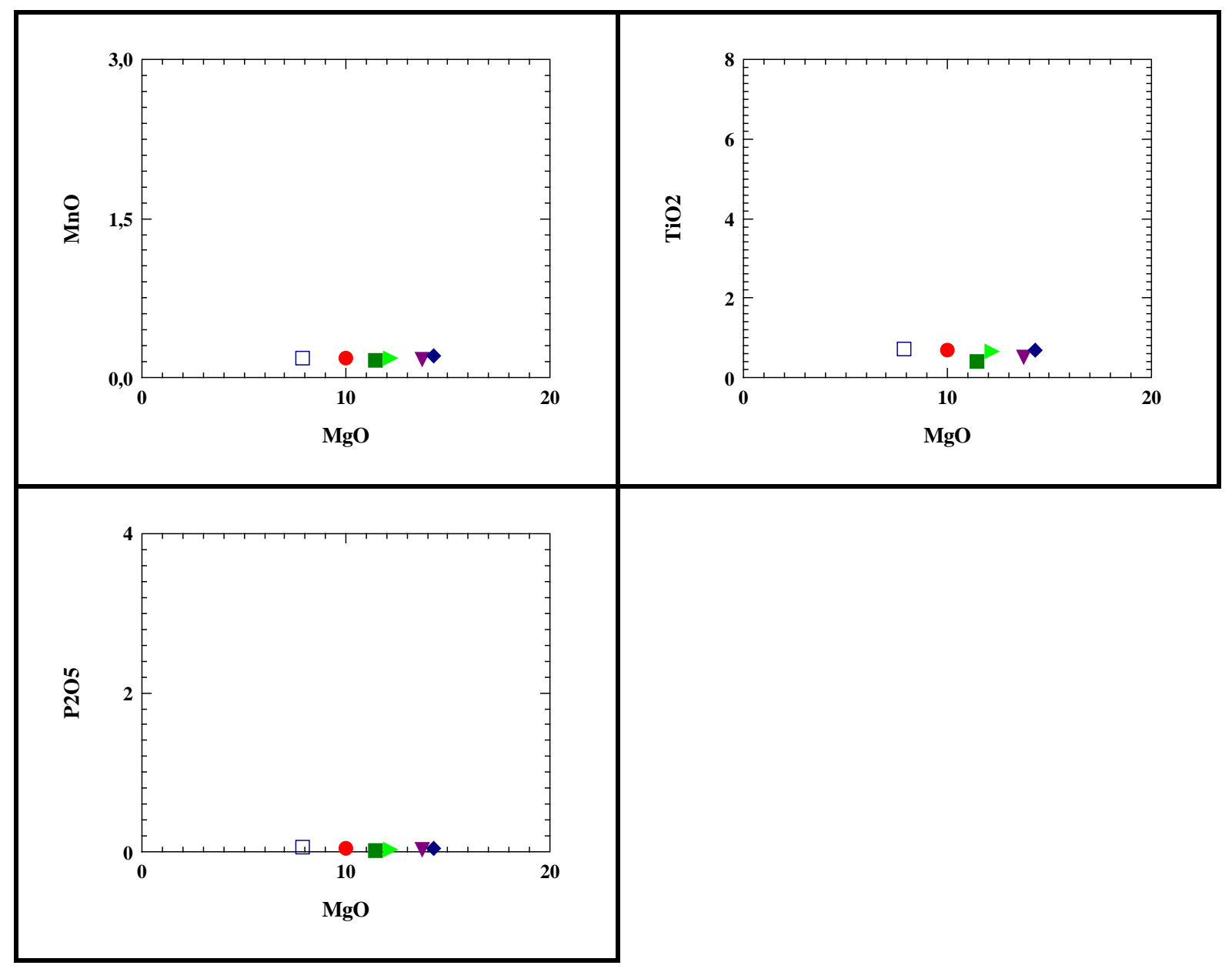

Figura 6.1: Diagramas de variação para elementos maiores e menores versus $\mathrm{MgO}$.

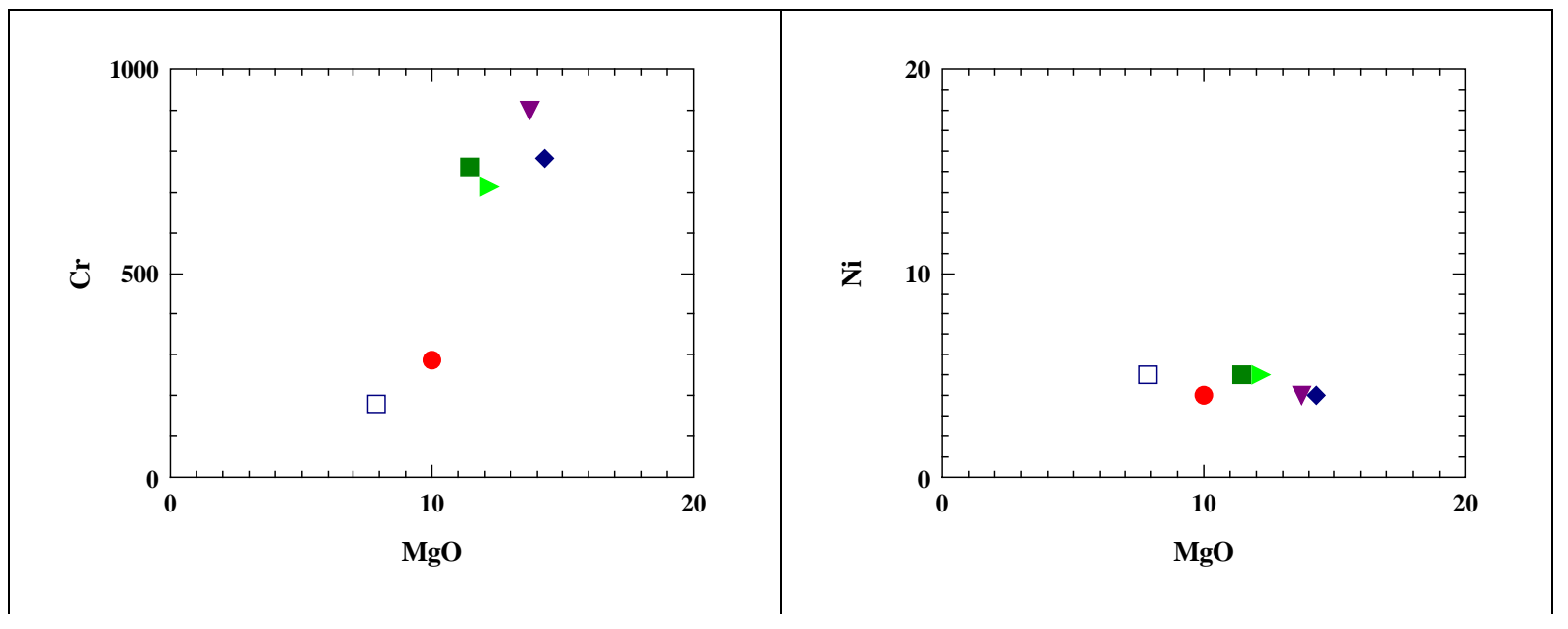




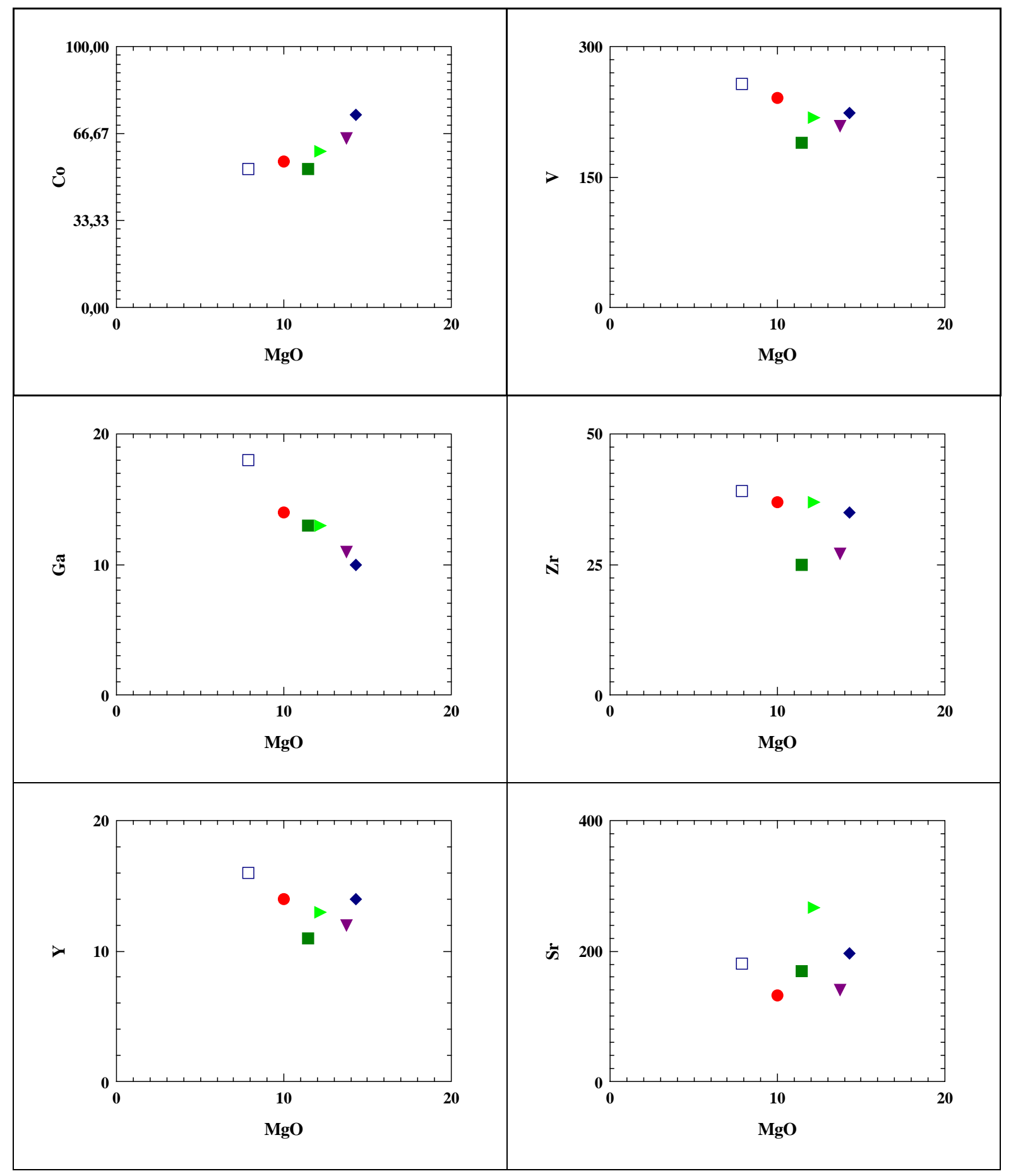




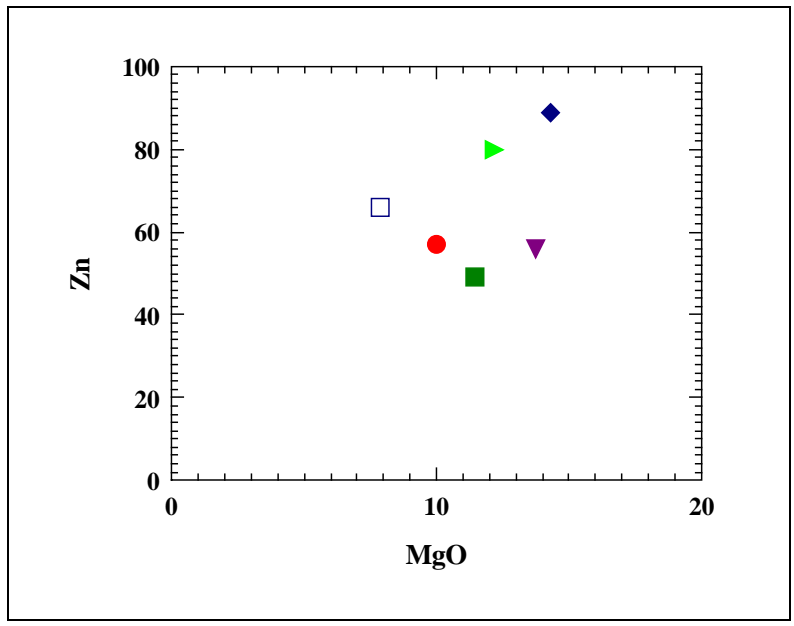

Figura 6.2: Diagramas de variação para elementos traço versus $\mathrm{MgO}$.

\subsection{Razões entre proporções moleculares (RPM) para elementos maiores}

Para elementos maiores e menores, um método que pode fornecer resultados significativos é o dos diagramas de Razões de Proporções Moleculares ou RPM (MPR - Molecular Proportion Ratios). Foi desenvolvido por Pearce (1968) para interpretar tendências de fracionamento em suítes ígneas e adaptado por Beswick e Soucie (1978) para avaliar a alteração em amostras de greenstone belts e utilizado para komatiitos por Beswic (1982, 1983). Este método fundamenta-se no princípio de que diagramas de variação binários podem ser enganosos, quando se trata de interpretações petrogenéticas, por apresentar variações relativas entre dois óxidos. Quando que se normalizados por um terceiro óxido que permanece constante no decurso do fracionamento, a variação entre os dois óxidos que estão sendo incorporados ao(s) mineral(is) em cristalização pode ser descrita em termos precisos, e sua relação se torna mais evidente. Em linhas gerais, espera-se uma correlação linear entre as razões dos elementos plotados no diagrama. Quando há um arranjo em leque que passa pela origem dos eixos do diagrama, este sugere a mobilidade do óxido utilizado para a normalização (considerando, é claro, os dois óxidos normalizados como relativamente imóveis). Quando se utiliza, no entanto de rochas composicionalmente modificadas, a dificuldade reside em identificar dois óxidos que não participem do fracionamento, e que não tenham sido significativamente mobilizados, para que os resultados obtidos com um deles possam ser aferidos com os outros (Vines, 1987). É necessário mencionar que existem opiniões discordantes com relação a utilização dos diagramas RPM, para avaliar a mobilidade química em komatiitos e basaltos alterados. Rollinson e Roberts (1986, 1987) e também Rollinson (1993) levantam objeções ao método, com base em argumentos estatísticos, sugerindo que poderia conduzir a correlações espúrias, resultantes de artifícios matemáticos, entre óxidos originalmente não correlacionados, e que não encontram respaldo em diagramas binários óxido-óxido convencionais. Na discussão que se segue, Vines (1987) e Pearce (1987) rebatem as críticas, enfatizando alguns princípios fundamentais para a utilização dos diagramas RPM: uma tendência de correlação representativa deve necessariamente apresentar um intercepto em y ou $\mathrm{x}$ diferente de zero, e uma pendente petrologicamente significativa. Tendências de 
correlação espúrias passariam necessariamente pela origem do diagrama e pelo ponto correspondente à composição média do conjunto de dados.

Para as amostras deste estudo foram utilizadas correlações entre os seguintes óxidos em Proporções Moleculares: $\mathrm{MgO}, \mathrm{CaO}, \mathrm{Al}_{2} \mathrm{O}_{3}, \mathrm{TiO}_{2}, \mathrm{FeOt}, \mathrm{Na}_{2} \mathrm{O}$ e $\mathrm{SiO}_{2}$, além do valor $\mathrm{FM}$, correspondente á soma de $\mathrm{MgO}$ e FeOt. As análises foram lançadas em diagramas RPM $\left(\mathrm{SiO}_{2} / \mathrm{N}\right) \mathrm{X}(\mathrm{FM} / \mathrm{N}),(\mathrm{MgO} / \mathrm{N}) \mathrm{X}(\mathrm{FeOt} / \mathrm{N}) \mathrm{e}$ $\left(\mathrm{MgO}\right.$ ou $(\mathrm{FeOt} / \mathrm{N}) \mathrm{X}(\mathrm{SiO} 2 / \mathrm{N})$, onde $\mathrm{N}$ representa os óxidos normalizadores $\mathrm{Na}_{2} \mathrm{O}, \mathrm{CaO}, \mathrm{Al}_{2} \mathrm{O}_{3}$ e $\mathrm{TiO}_{2}$ (Figura 5.3).

O método a princípio mostrou-se eficiente confirmando alguns padrões já verificados nos gráficos para elementos maiores versus $\mathrm{MgO}$. Para os gráficos RPM onde foi plotado o $\mathrm{Na} 2 \mathrm{O}$ observa-se que o alinhamento das amostras passa pela origem, indicando a remobilização deste elemento.

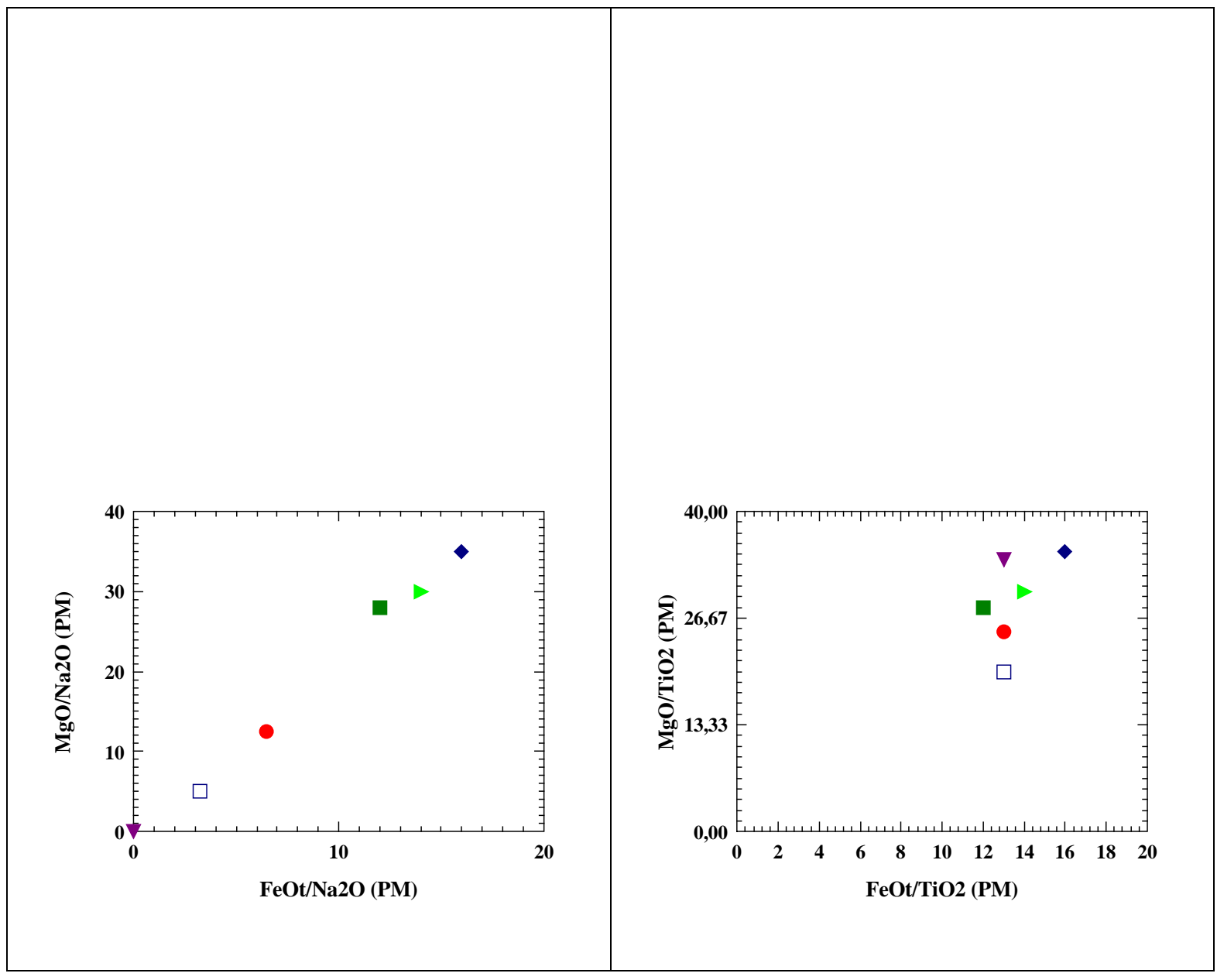




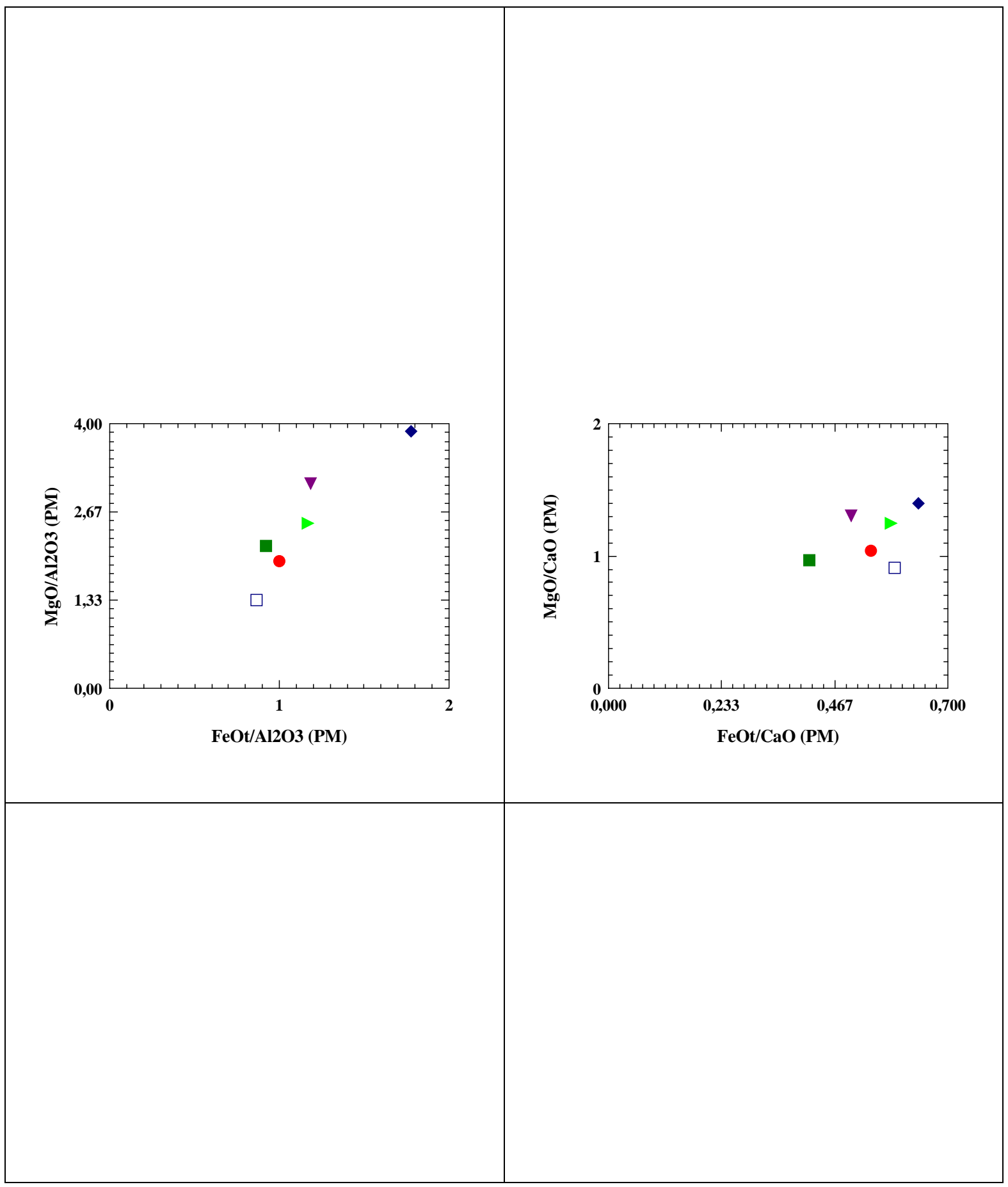




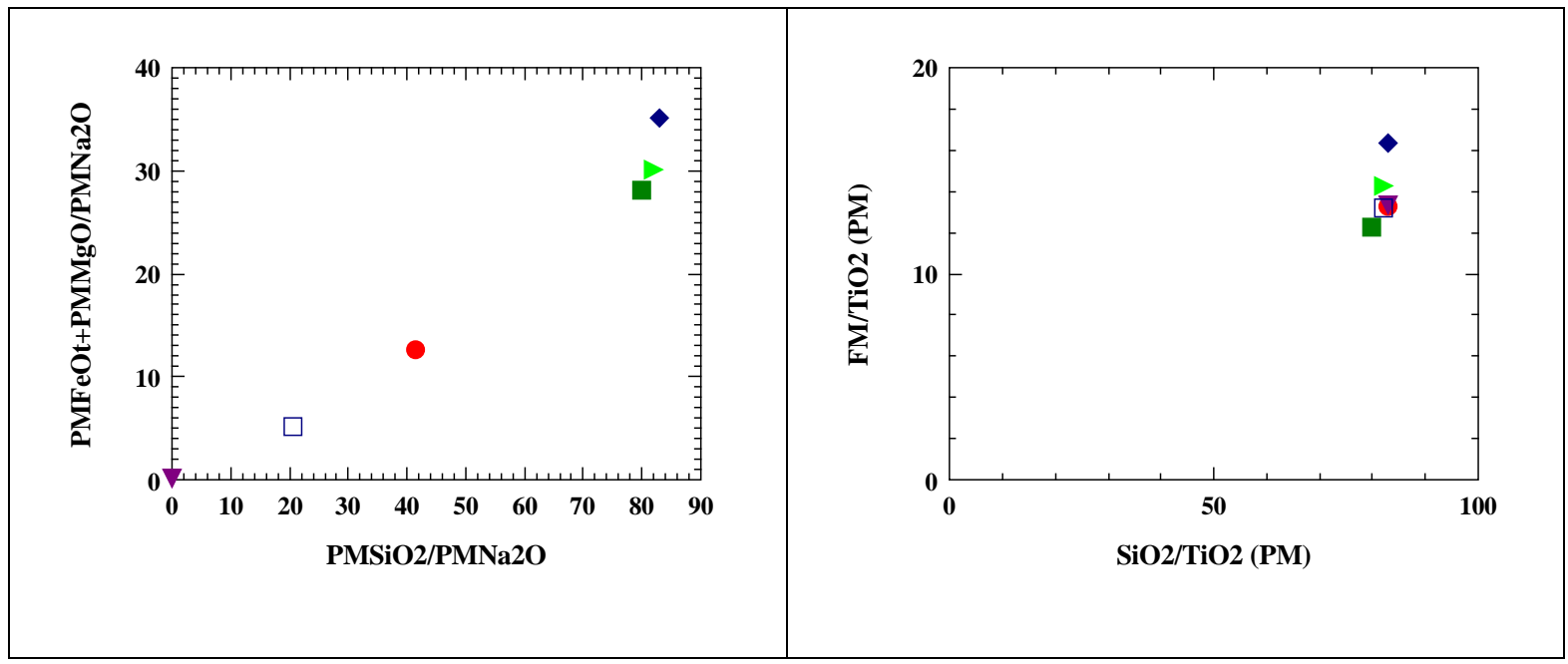

Figura 6.3: Gráficos de razões entre proporções moleculares para os elementos maiores.

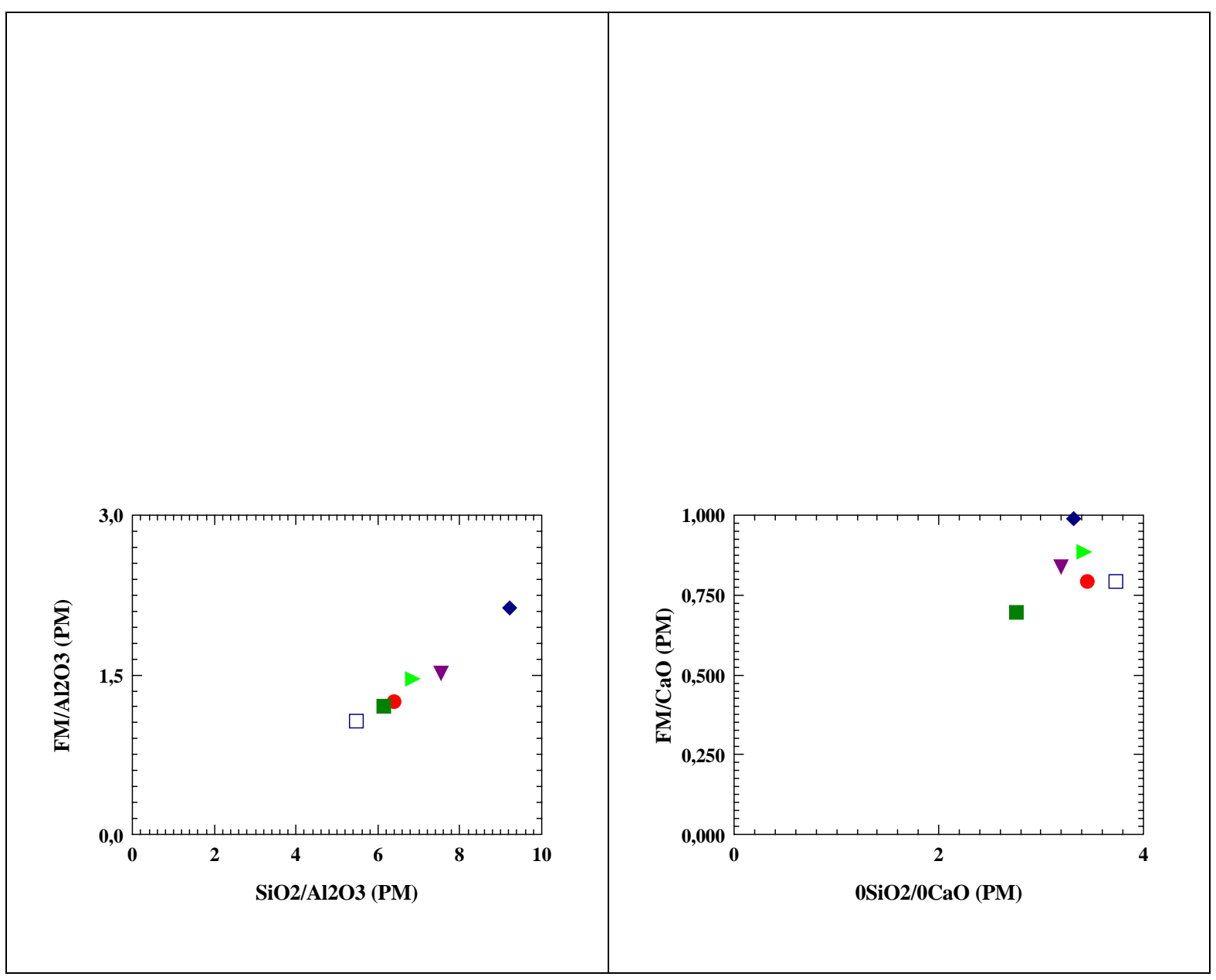




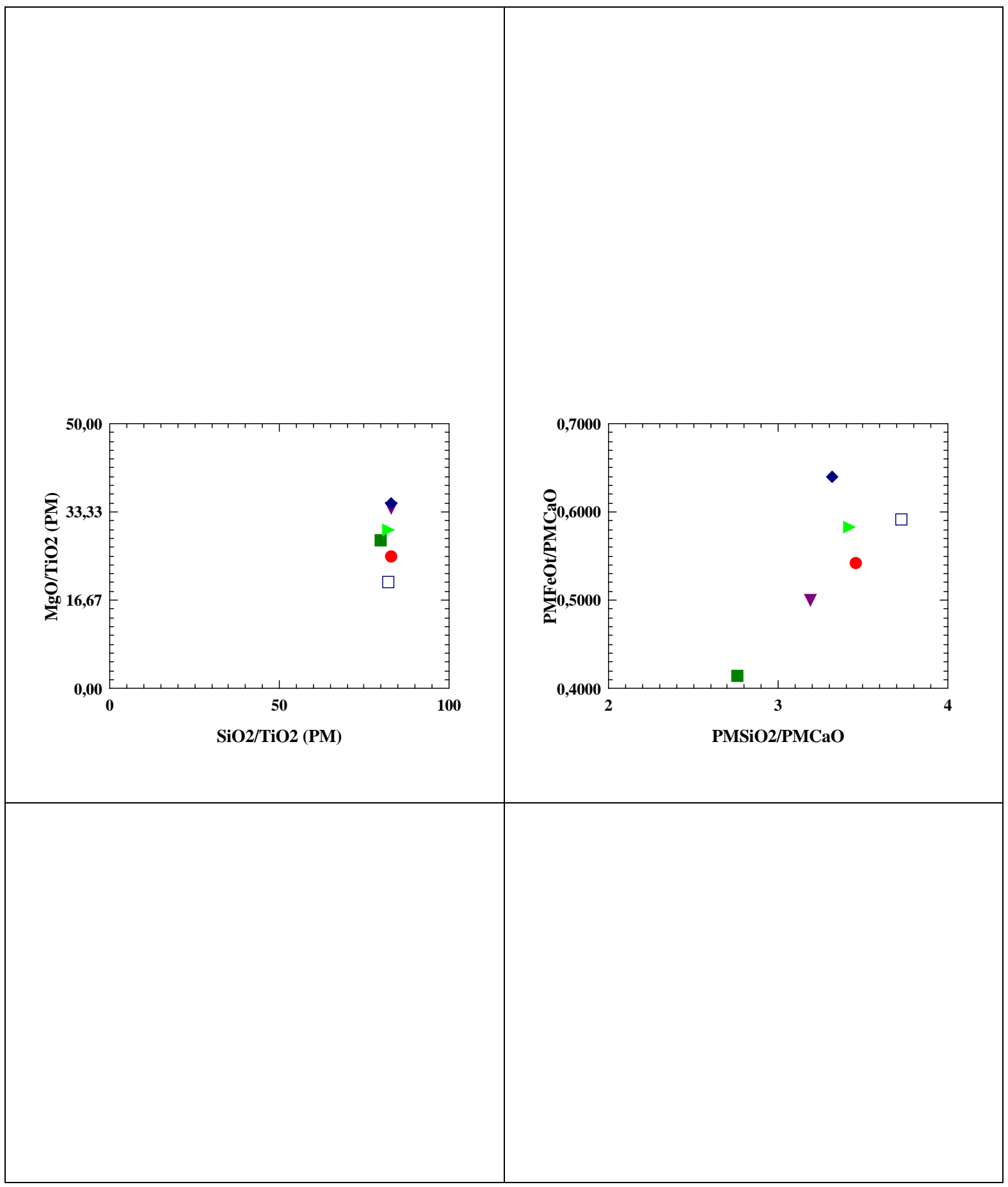




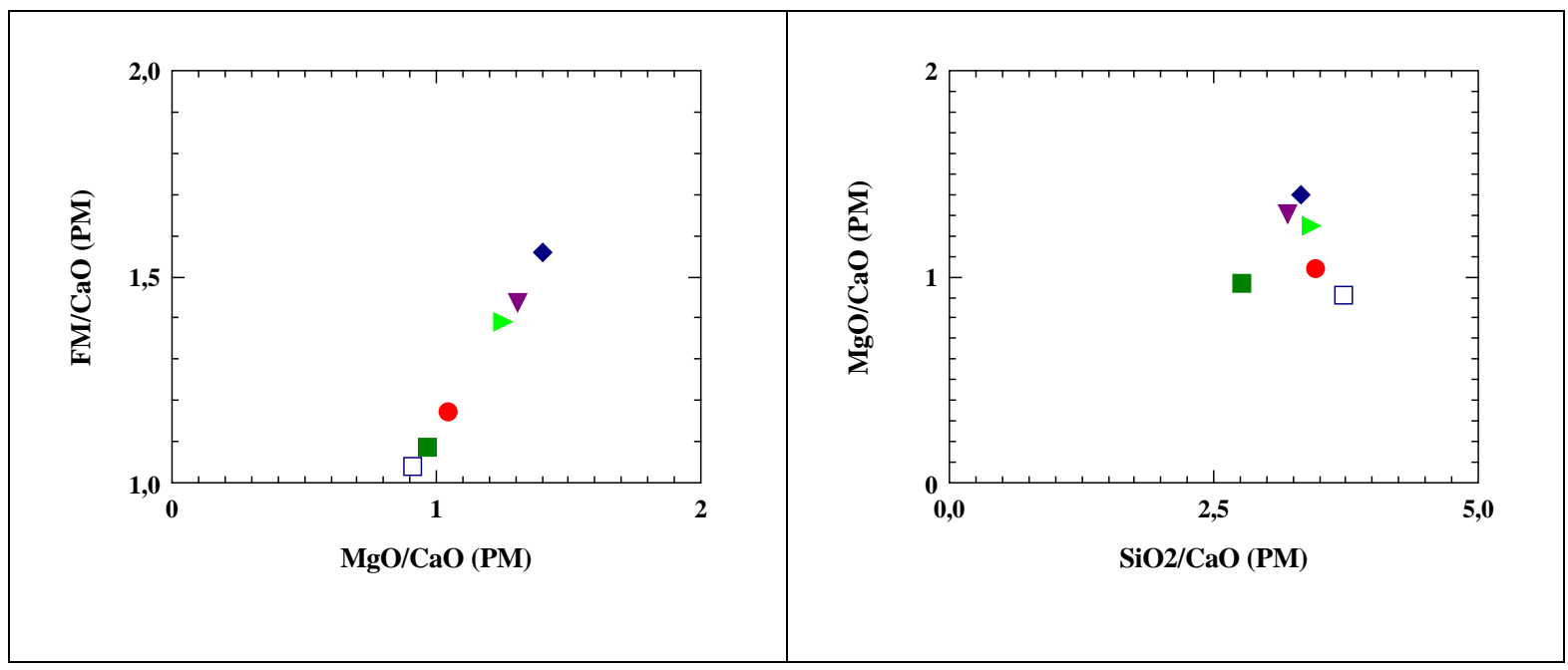

Figura 6.3: Gráficos de razões entre proporções moleculares para os elementos maiores.

\subsection{Elementos Terras Raras (ETR)}

Os dados obtidos para as rochas metabásicas da Formação Betara foram normalizados de acordo com os valores do condrito de Haskin (1968) conforme a figura 5.4. Os gráficos foram separados em 3 conjuntos de acordo com as anomalias características observadas para os ETR. O primeiro conjunto está representado pelas amostras LBT-20, LBT-7A, LBT-9B. Tal conjunto apresenta anomalias negativas para o Ce mais com padrões mais discretos, assim como as anomalias de Eu (exceção para a amostra LBT-20 onde esta ocorre mais pronunciada). O segundo conjunto corresponde às amostras LBT-17A e LBT-9A e apresenta amostras com anomalias negativas para o $\mathrm{Ce}$, mais pronunciadas em relação às anomalias positivas de Eu (figura 5.4). Já o terceiro conjunto, que corresponde na realidade a apenas uma amostra (LBT-17B), não ocorre a anomalia negativa para o Ce e apresenta uma anomalia negativa para o $\mathrm{Eu}$ (figura 5.4).

Os ETR exibem de maneira geral um padrão em corcova para as amostras analisadas com empobrecimento generalizado para os ETR pesados. Destacam-se duas anomalias características para os ETR leves: Um enriquecimento em La com amplitudes variáveis desde um pico de 10 vezes o condrito ( amostra LBT-20), até amplitudes mais modestas de 4,5 vezes o condrito (amostra LBT 17B). Outra anomalia característica dos ETR leves destaca-se pelo empobrecimento em Ce para algumas amostras, com exceção da amostra LBT 17B.A razão La/Sm $\mathrm{Sm}_{(\mathrm{N})}$ é de 1,46 para os ETR leves .

Para os ETR pesados nota-se ainda uma anomalia positiva para todas as amostras (com amplitudes variáveis) para o Ho. A razão $\mathrm{Gd} / \mathrm{Yb}_{(\mathrm{N})}$ para os ETR pesados é de 1,60. 

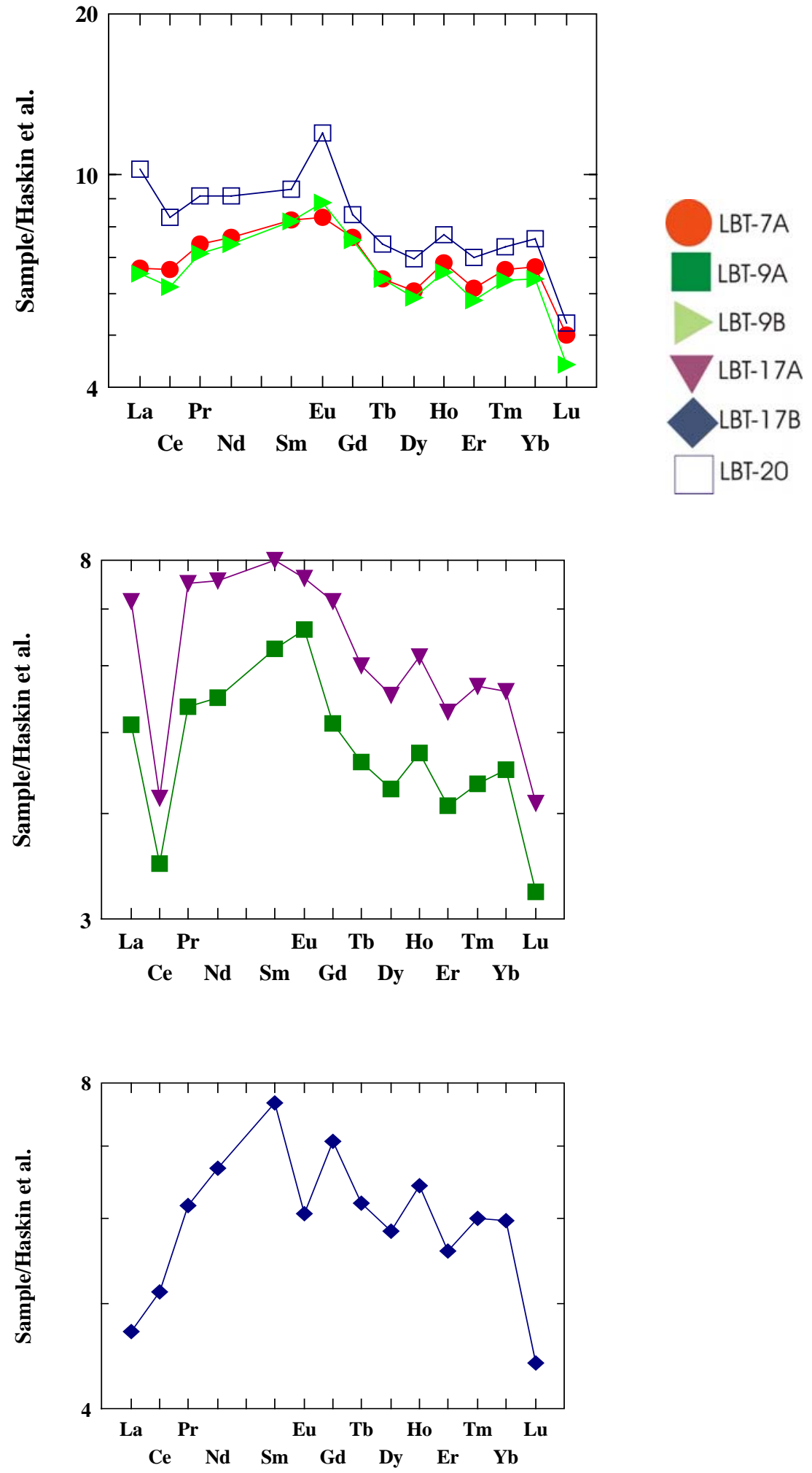

Figura 6.4: Distribuição dos elementos terras raras para as amostras deste estudo. 
O padrão dos ETR observado para as rochas metabásicas da Formação Betara, de um modo geral, denota relativo enriquecimento em ETR leves e anomalias de Ce, mostrando-se similares aos apresentados no trabalhos de Frey et al. (1973) para basaltos do assoalho oceânico, Ludden e Thompson (1978) para espilitos de Borwada, por Hellman e Henderson (1977) para os derrames de Decan na Índia. Wood et al. (1976) também identificam enriquecimento diferencial em ETR leves, preferencialmente o La, durante o metamorfismo no fácies zeólita em basaltos terciários na Islândia.

O mecanismo de remobilização de ETR sob condições de metamorfismo de grau muito baixo, é motivo de discussões na literatura. Ludden e Thompson (1978) destacam similaridades existentes entre padrões observados em basaltos alterados (paloganitizados) em lavas almofadadas e o padrão característico para a água do mar, onde o potencial de hidrólise decresce de forma marcante do La em direção ao Sm.Neste caso, o comportamento dos ETR pesados se mostra relativamente constante e se destaca o marcante empobrecimento de Ce. Este é mais facilmente removido na forma de $\mathrm{Ce}^{+4}$, incorporando-se então aos nódulos de $\mathrm{Mn}$ como $\mathrm{CeO}_{2}$ (Brookins 1989).

Tais padrões são aparentemente mais realçados para lavas antigas que sofreram maior exposição, permanecendo maior tempo em contato com a água do mar. Discute-se uma significativa fixação de ETR durante a alteração submarina de baixas temperaturas, tendendo a uma mimetização no processo. Porém há dependência do padrão ETR primário das rochas, bem como da existência de fases minerais secundárias que incorporem ou adsorvam os ETR, além do tempo disponível para a alteração.

O processo de solubilização-complexação e de precipitação-fixação para os ETR é ainda insatisfatoriamente esclarecido, podendo variar significativamente, na dependência de condições físico-químicas do meio (Broockins 1989; Wood 1990).

Bienvenu et al. (1990) admitem a remoção preferencial dos ETR em basaltos MORB alterados em comparação a Zr, Hf, Nb, e Ta no lugar do enriquecimento descrito por Frey et al. Ludden e Thompson (1978) e Wood (1976) também para basaltos MORB.

O resultado da mobilidade dos ETR é dependente da combinação de uma série de fatores independentes: ambiente de alteração, (subaquática "fria", ou tardi-magmática hidrotermal "quente", ou ainda metamórfica de soterramento do fácies zeólita e prehnita-pumpellyta); 
composição e características físico-químicas ( $\mathrm{pH}$, temperatura e pressão, salinidade) da fase fluida circulante; porosidade original da rocha; composição mineralógica primária, incluindo presença de fases vítreas cripto cristalinas mais reativas; constituição mineralógica e seqüências de desenvolvimento das fases secundárias/metamórficas; tempo de atuação do processo. Hellman et al. (1979) comentam alguns destes fatores ao caracterizar os principais tipos de modificaçõs encontradas para os padrões ETR.

Fica evidente que não existe uma modelagem única possível para os padrões ETR modificados em rochas vulcânicas alteradas/metamorfisadas.

A complexidade das possíveis combinações entre as variáveis envolvidas, aliada ao conhecimento incompleto do comportamento físico químico dos ETR em meio aquoso, permite apenas uma abordagem comparativa dos dados obtidos.

\subsection{Gráficos Multielementares Normalizados (spidergrams)}

Á partir dos spidergrams procura-se, através da análise de elementos incompatíveis, compreender os processos geradores dos magmas basálticos Busca-se estabelecer comparações entre os valores normalizados, relacionando possíveis fontes para o magma gerador dos conjuntos de rochas.

Os dados obtidos neste estudo não permitem reunir informações adequadas para apontar com alguma precisão padrões geoquímicos originais ígneos preservados. Nem mesmo é possível reconstruí-los tentativamente à partir do conhecimento mais apurado dos processos de alteração que atuaram sobre as rochas deste estudo.

Os elementos LIL, por exemplo, não apenas estão em concentrações muito baixas, como muito provavelmente foram mobilizados. Os ETR, como já visto, sofreram alteração em seus padrões normalizados, possivelmente ainda no estágio tardi-pós vulcânico. A ausência de uma série de parâmetros, inviabiliza um esclarecimento mais detalhado para os processos petrogenéticos envolvidos na gênese e evolução do magma basáltico original.

Dentre estes, podemos destacar o grau de alteração intempérica; ambiente de colocação e transformações pré, sin e pós metamórficas, bem como deformações sucessivas e sobrepostas.

A título de ilustração foram confeccionados diagramas normalizados pelo condrito $\mathrm{C} 1$, basaltos do tipo MORB, manto primitivo e basaltos de ilhas oceânicas (figura 5.8) para as rochas metabásicas da Formação Betara.

Quando comparamos os valores obtidos em relação ao condrito $\mathrm{C} 1$ observa-se que o $\mathrm{Rb}$ apresenta valores próximos a 1, elementos entre o U e o Cr estão enriquecidos, assim como o Ta e o Zn. O níquel apresenta-se fortemente empobrecido em relação ao MORB. 
Em relação aos basaltos do tipo MORB nota-se enriquecimento em Ba, Rb, U, Zn e Ta. O Ce está fortemente empobrecido. Zr, Tb e Y também mostram-se empobrecidos, bem como o Ni que apresenta forte empobrecimento em relação aos MORB.

Comparados ao manto primitivo, nota-se um forte enriquecimento em $\mathrm{Rb}$ (da ordem de 10X o manto primitivo), enquanto os valores de $\mathrm{Ba}$ e $\mathrm{U}$ ficam muito próximos de 1 . O Nb, $\mathrm{Ce}, \mathrm{Tb}, \mathrm{Sr}$ e $\mathrm{Y}$ apresentam um leve enriquecimento. Já o $\mathrm{Zr}$ apresenta-se bastante enriquecido, cerca de 20X o manto primitivo. O Cr e o Ni estão bastante empobrecidos, enquanto o Ta e o $\mathrm{Zn}$ apresentam um enriquecimento entre 10 e 40X o manto primitivo.

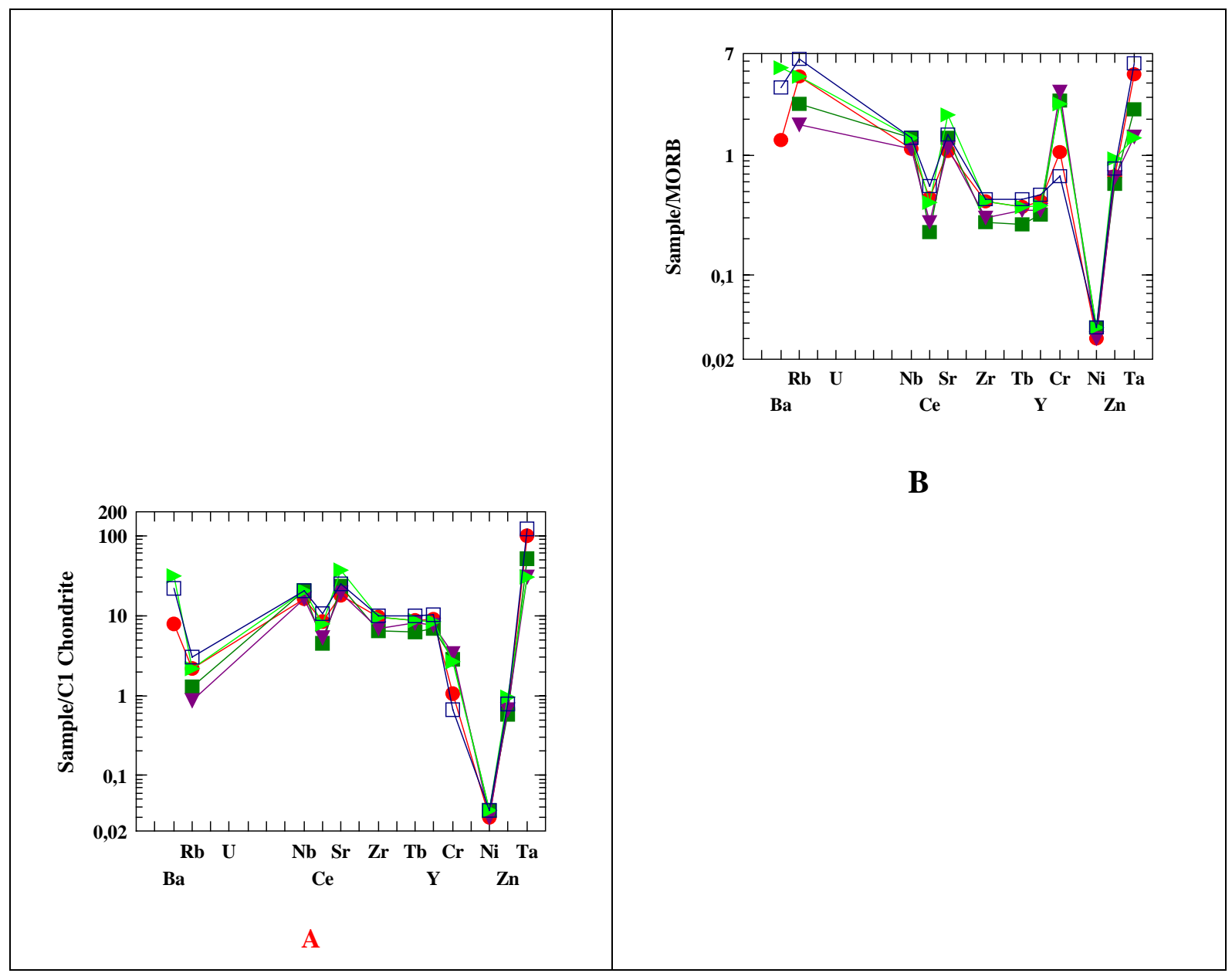




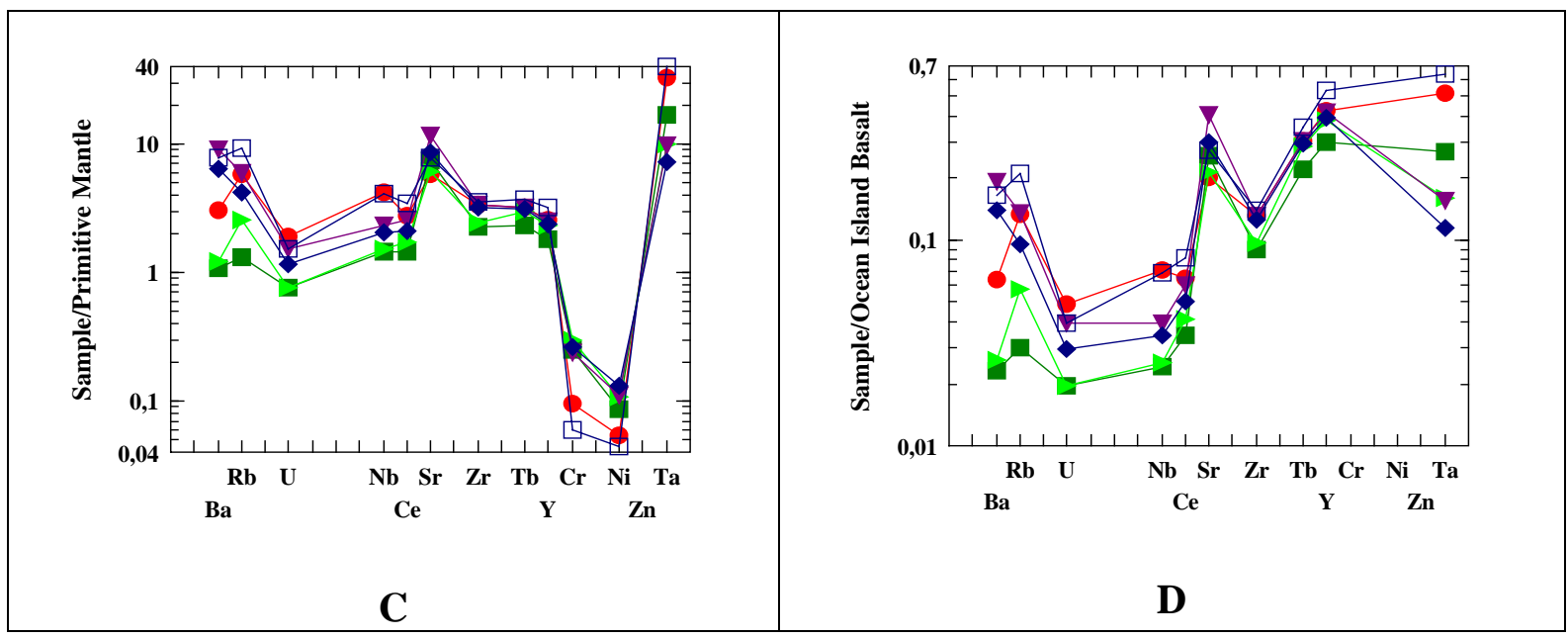

Figura 6.5: Diagramas multielementares mostrando a composição das rochas deste estudo comparadas com a composição de basaltos de diferentes ambientes tectônicos: (A) Condrito C1, (B) MORB, (C) manto primitivo, (d basaltos de ilhas oceânicas.

\subsection{Diagramas de Classificação}

Inicialmente, uma simples observação da tabela 1, destacam-se os teores obtidos em $\mathrm{SiO} 2$, distribuídos entre aproximadamente 47 e 49\%, indicativos de rochas de natureza basáltica.

Destaca-se ainda o empobrecimento em álcalis destas rochas, já discutido no estudo das seções delgadas à partir do comportamento da albita que ocorre concentrada em veios (amostra LBT-7 A) ou em bolsões (LBT20).

Utilizando-se do diagrama ácalis versus sílica (figura 5.6) observa-se que as amostras distribuem-se abaixo do campo relativo às rochas basálticas, com exceção da amostra LBT-20 que em seção delgada denotou maior concentração de albita visível na forma de bolsões. Reflete portanto uma remobilização de álcalis nestas rochas indicativas de modificação no quimismo do protolito ígneo. Quando utilizamos dos diagramas AFM e álcalis versus $\mathrm{SiO} 2$ de Irvine \& Baragar (1971), observa-se que as amostras distribuem-se no campo dos basaltos toleíticos pouco evoluídos (figuras 5.7 e 5.8). No diagrama de Cox et al. (1979) estas rochas distribuem-se no campo dos basaltos sub alcalinos denotando o empobrecimento em álcalis destas rochas (figura 5.6).

Utilizando-se de diagramas para elementos menos móveis como os de Winchester e Floyd (1977) estas rochas se projetam no campo dos basaltos subalcalinos (figuras 5.9). Nas figuras 5.7, 5.8 e 5.9 foram plotados dados relativos a rochas metabásicas que ocorrem no âmbito da Faixa Apiaí. Referem-se a metabásicas intercaladas às formações Água Clara (Weber, 2004; Maniesi, 1997 e 2000; Frascá et al., 1990) e Perau (Daitx, 1996). 
Frascá et al. (1990) realizaram análises litogeoquímicas em rochas metabásicas que ocorrem na região de Araçaíba (SP). Indicam para o evento magmático gerador destas rochas de natureza toleítica, representativos de basaltos de fundo oceânico transicionais (T- MORB) ou toleíto de arco insular imaturo.

Maniesi (1997) e Maniesi et al. (2000) realizaram estudos geoquímicos envolvendo elementos maiores, traços e terras raras de rochas anfibolíticas e metabásicas de três regiões distintas, Adrianópolis PR, Campo Largo - PR e Rio Branco do Sul - PR no âmbito da Formação Água Clara. Sugerem origem ortoderivada, com composição química similar a basaltos oceânicos e características de E-MORB tendendo à OIB (Adrianópolis), T-MORB com afinidades toleíticas de alto magnésio (Campo Largo) e para os corpos de Rio Branco do Sul, basaltos de cadeias meso oceânicas, N-MORB com empobrecimento em elementos incompatíveis. Os autores op cit.sugerem ambientes de retro arco.

Os dados geoquímicos obtidos por Daitx (1996), em anfibolitos e metabásicas da Formação Perau, sugerem natureza basáltica não diferenciada, de caráter toleítico sub alcalino, indicativo de ambientes distensivos.

Acrescente-se que ambientes de natureza distensiva foram propostos por Soares (1987), Daitx (1996) e Basei et al. (2002) através de dados geoquímicos de rochas metabásicas das Formações Perau e Votuverava.

O estudo petrográfico e geoquímico dos corpos metabásicos da Formação Betara, embora bastante preliminares, uma vez que foram poucas amostras analisadas, indica a natureza ortoderivada destas rochas e um quimismo sugestivo de protolitos basálticos subalcalinos, indicativos de ambientes tectônicos distensivos.
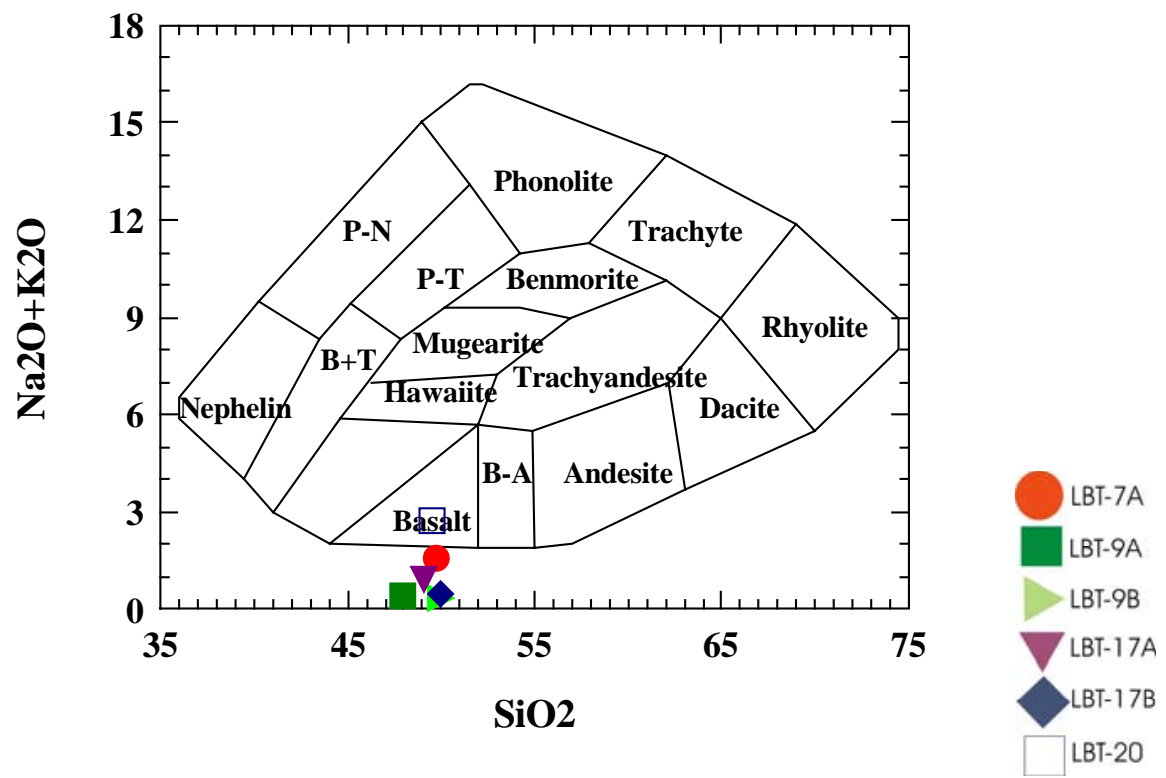

Figura 6.6: Diagrama álcalis versus sílica de Cox et al. (1979). 


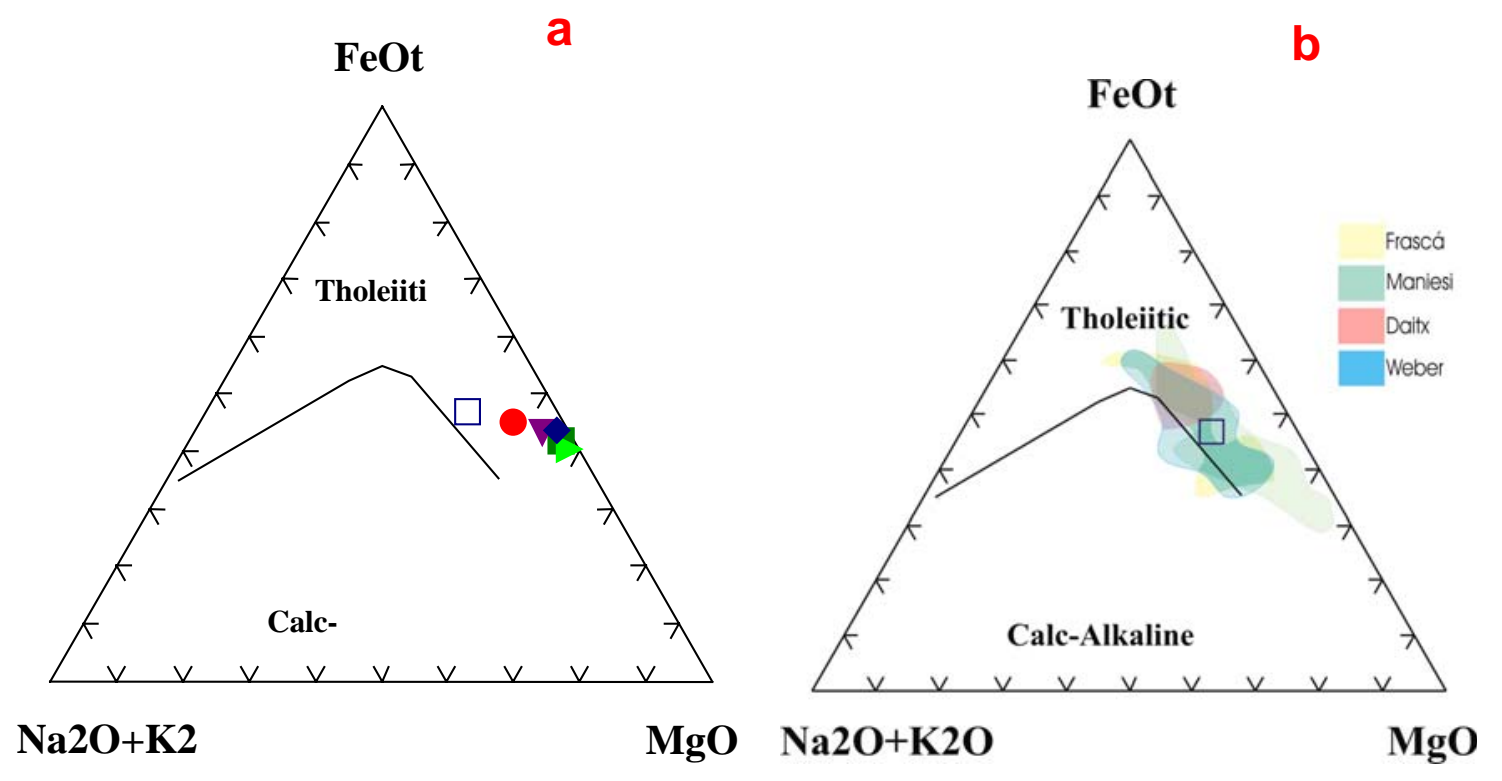

Figura 6.7: Diagrama AFM de Irvine \& Baragar (1971)a - apenas para amostras LBT e b- para demais estudos realizados com rochas metabásicas no pré-Cambriano paranaense (Daitx, 1996; Maniesi, 1997; Frasca, 1990; Weber, 2004)
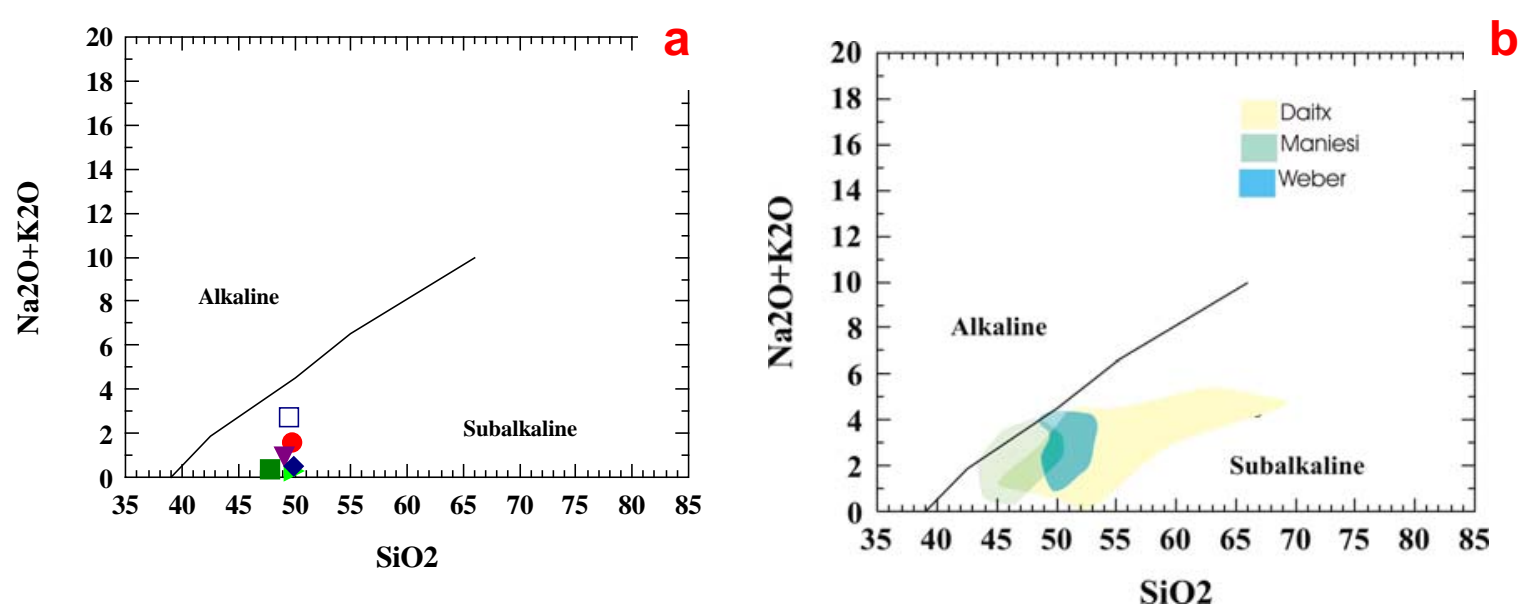

Figura 6.8: Diagrama de Álcalis versus Sílica de Irvine \& Baragar (1971) a - apenas para amostras LBT e b - para demais estudos realizados com rochas metabásicas no pré-Cambriano paranaense (Daitx, 1996; Maniesi, 1997; Weber, 2004) 

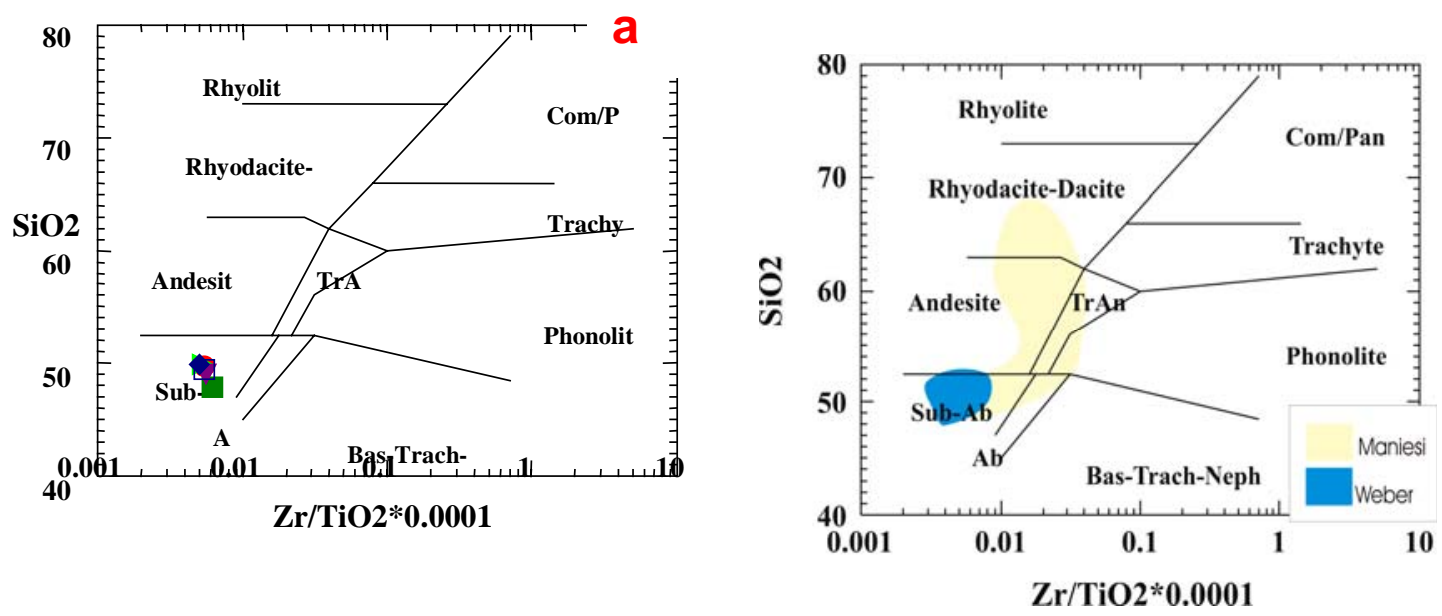

Figura 6.9: Diagramas $\mathrm{SiO} 2$ versus $\mathrm{Zr} / \mathrm{TiO} 2 * 0.0001$ de Wynchester \& Floyd (1977) a- para amostras deste estudo b- Estudos realizados no Pré Cambriano paranaense (Frasca,1990 e Weber,2004)

\subsection{CONTEXTO ESTRUTURAL DA REGIÃO DO BETARA}

A primeira referência à uma tectônica de nappes no Grupo Açungui deve-se à Ebert (1971). Esta tectônica só volta à ser enfocada à partir da década de 80, principalmente com os trabalhos de Fiori (1985, 1987, 1989, 1990), Soares e Reis Neto (1987), Hasui et al. (1984), Campanha et al. (1987), Salamuni et al. (1993), Yamato (1999), Fassbinder (1991), Daitx (1996), Kaulfuss (2001) e Cury (2003).

No âmbito da Formação Betara, o antigo acamadamento sedimentar pode ser facilmente recuparado. De modo geral é identificado por diferenças composicionais, de granulometria (figura7.1), estratificações gradacionais, estratificações cruzadas (figura 7.2), ou mesmo pela alternância de níveis com diferentes cores. 


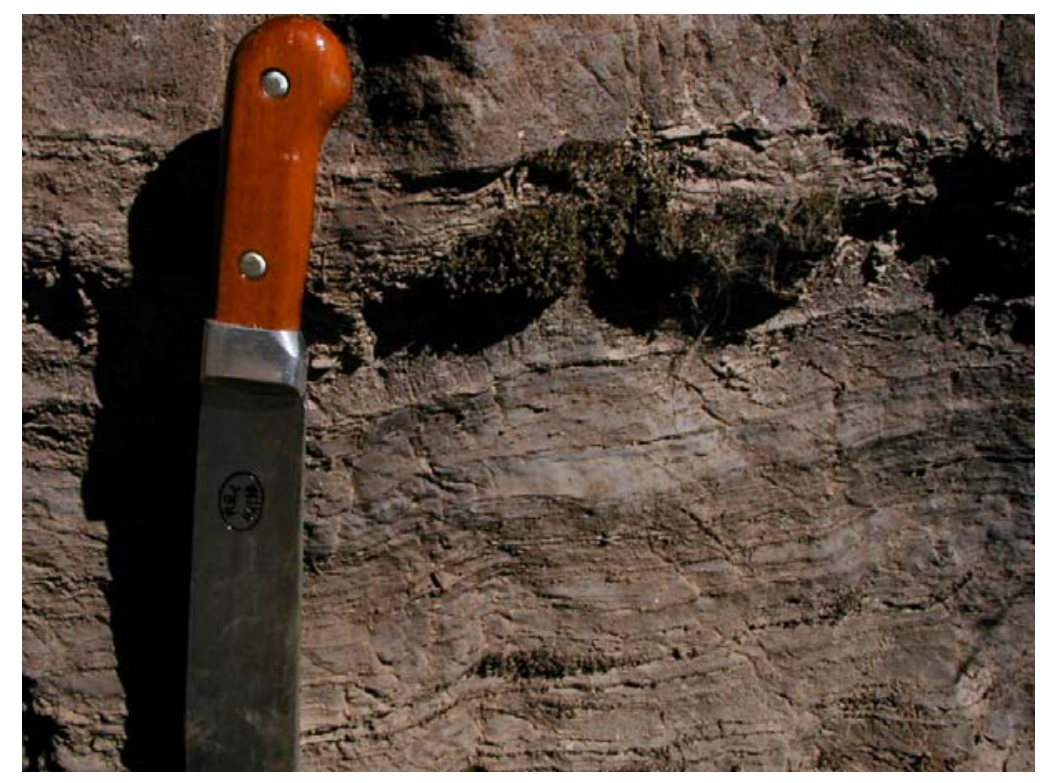

Figura 7.1: Variação granulométrica em margas (S0) afloramento LBT-33.

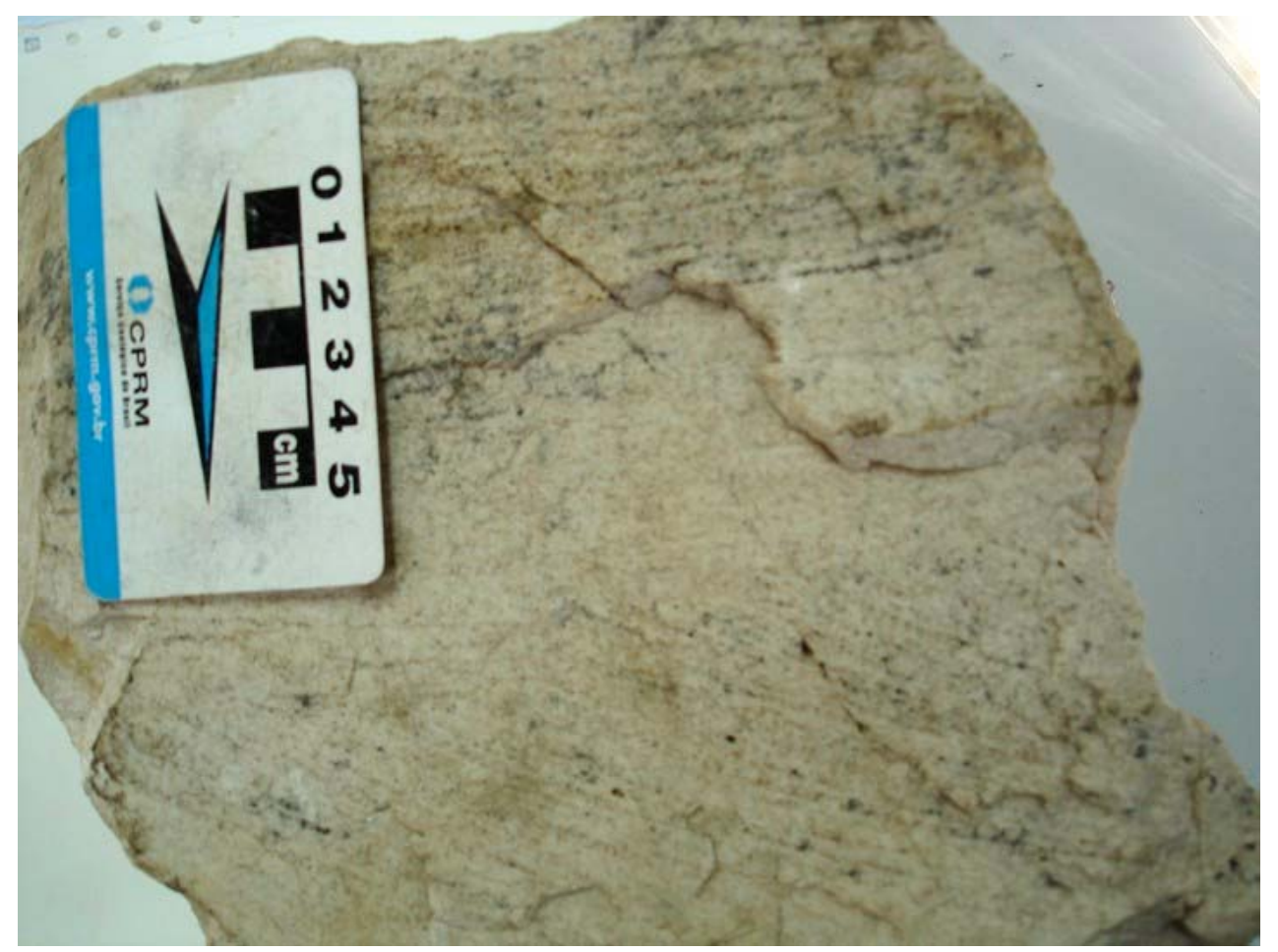

Figura 7.2: Estratificação cruzada em amostra de quartzito do afloramento LBT-01.

A foliação S1 está sempre presente paralela ou sub-paralela ao acamadamento sedimentar (S0). Trata-se de uma foliação de cisalhamento (Sc), de baixo à médio ângulo, responsável pelo fatiamento, lenticularização e formação de micrólitons, com lineações e indicadores cinemáticos (principalmente relações Ss X Sc) sugestivos de transporte de NW 
para SE. Não se trata de uma xistosidade, e sim de uma clivagem ardosiana, uma vez que na maioria dos afloramentos, observa-se uma fina cristalização de sericita. A intensificação de S1 é observada principalmente nas proximidades das falhas de cavalgamento, a exemplo da Falha da Boa Vista e da Falha do Betara, onde o estiramento se torna mais pronunciado, com desenvolvimento de muscovitas, biotitas e por vezes granada (afloramentos: LBT 39, LBT 64, LBT 65, LBT 69). Outro importante aspecto desta foliação é seu anastomosamento, formando planos irregulares com contatos em ângulos.

Há discussões na literatura à respeito desta foliação representar uma superfície S1 ou S2, função principalmente da presença esporádica de dobras (centiméticas à decimétricas), fechadas, isoclinais que são desenhadas por S0 (D1) ou mesmo por S1, com flancos rompidos, interpretadas como intrafoliais (D2) (figura 7.3). Adotaremos para esta foliação o termo "Sn".

Observa-se localmente planos também de baixo à médio ângulo, que truncam a foliação anterior Sn. Assim como Sn refere-se a uma clivagem ardosiana, com desenvolvimento de serecita. Próxima às zonas de cisalhamento parece estar melhor desenvolvida a exemplo do afloramento LBT-31 representado por metamargas, junto à Falha da Boa Vista.

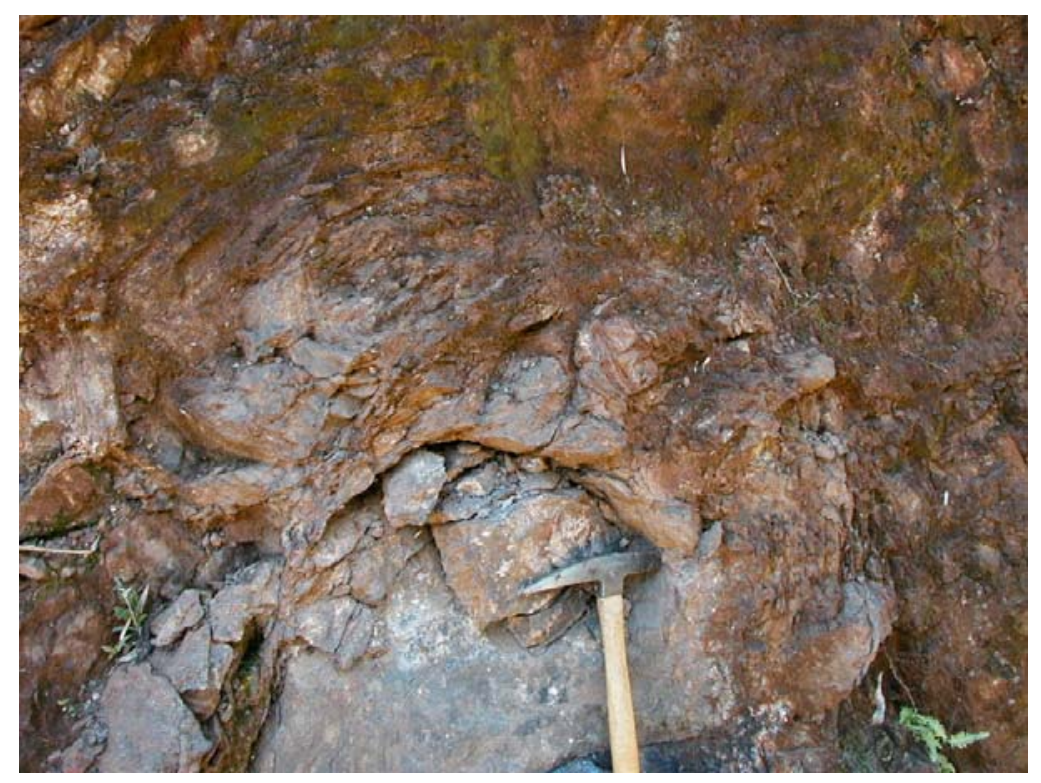

Figura 7.3: Dobra métrica D2 em rochas calciossilicáticas (afloramentoLBT-44) 


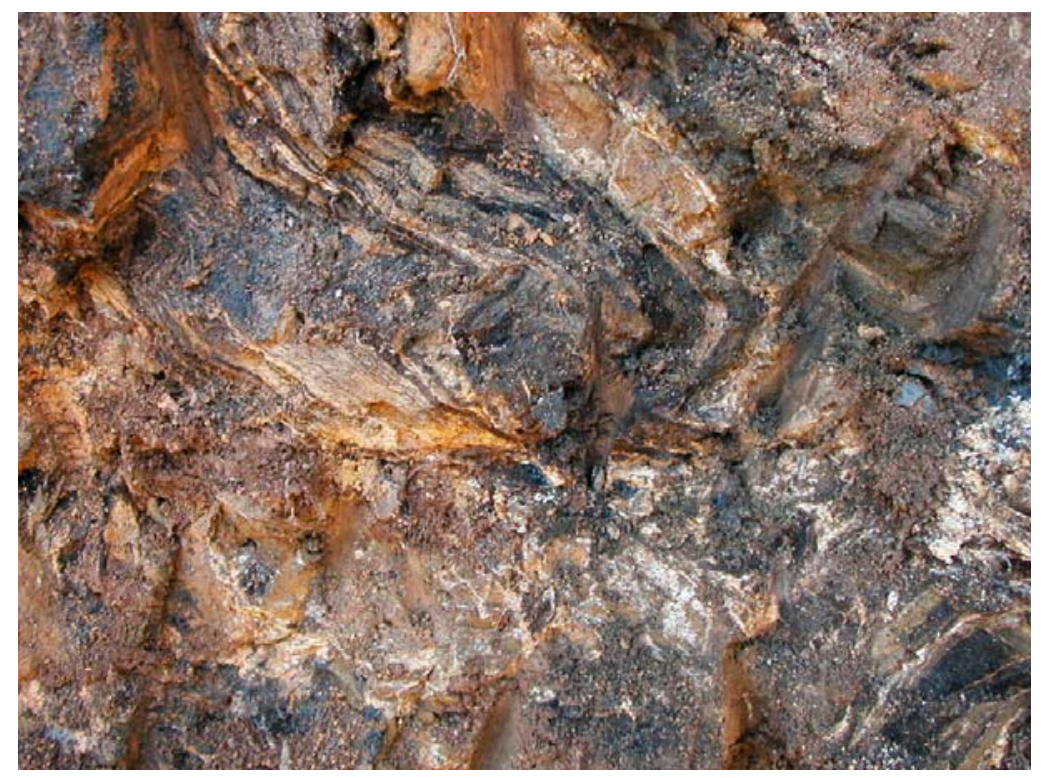

Figura 7.4: Dobra métrica D2 em rochas calciossilicáticas (afloramentoLBT-44)

Dobramentos tardios foram observados em inúmeros afloramentos através de ondulações centimétricas a métricas e crenulação da superfície Sn. Desenvolve uma clivagem espaçada em posição plano axial à esses dobramentos. Estes dobramentos foram bem caracterizados nos litotipos metavulcanossedimentares da Formação Betara que ocorrem no setor ocidental, através de análise das foliações Sn em diagramas de ShimidtLambert, utilizando-se da projeção polar (figura 7.6). Este diagrama caracteriza a foliação Sn de baixo à médio ângulo afetada por um dobramento cilíndrico (D2), com eixos NESW, horizontalizados (S28W/10). Os planos $\mathrm{Sn}+1$ apresentam-se com mergulhos relativamente elevados em posição plano axial à esse dobramento. As poucas lineações de estiramento caracterizadas nestes litotipos (função do grau de alteração) posicionam-se principalmente no quadrante NE com mergulho relativamente baixos.

A dispersão observada dos polos de $\mathrm{Sn}$ e $\mathrm{Sn}+1$ (figura 7.6), e a caracterização em campo de ondulações destas superfícies com o desenvolvimento de uma clivagem espaçada $\mathrm{Sn}+2$ indicam um redobramento (D3) destas superfícies, bem evidenciada em metamargas no afloramento LBT-67 (figura 7.5). 


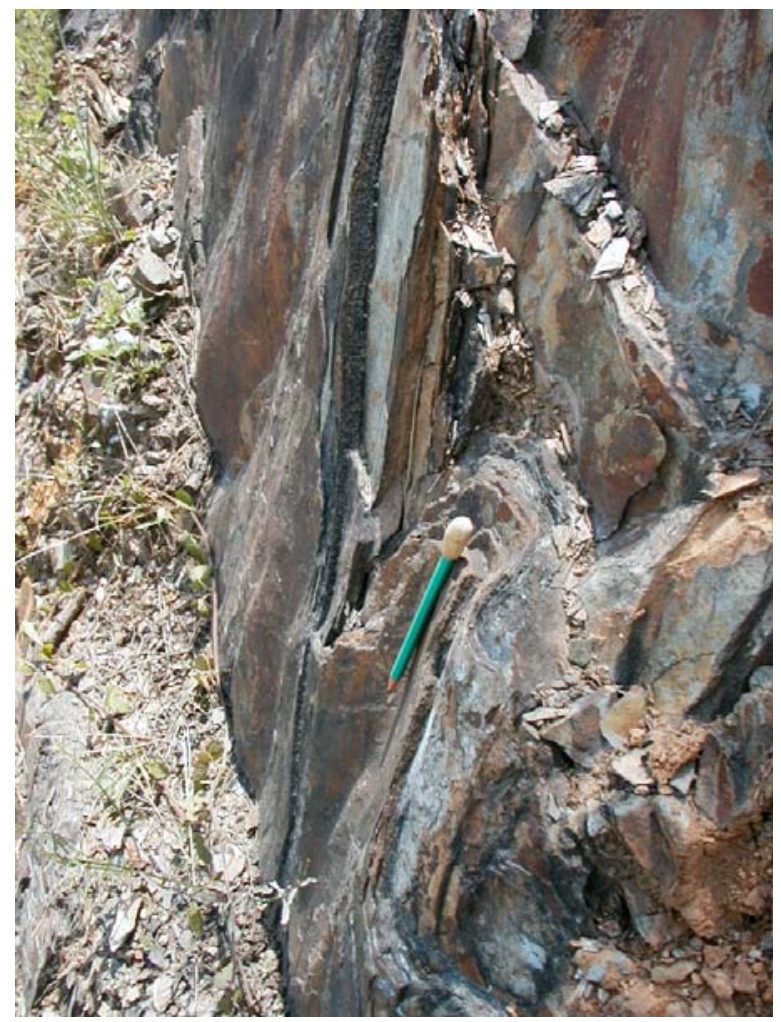

Figura 7.5: Dobras tardias em meta-margas (ponto LBT-67)

Os eixos mostram-se horizontalizados com fracos mergulhos tanto para o quadrante NW como para SE. As superfícies $\mathrm{Sn}+2$ são verticalizadas e distribuem-se em posição plano axial (figura 7.6). Este padrão é bastante similar ao observado pouco a norte para a seqüência Votuverava (figura 7.7), denotando concordância estrutural entre estes litotipos. Tal concordância estrutural foi sugerida por Fiori (1990). Embora preliminar (função dos poucos dados analisados), tal padrão de dobramentos tardios, parece afetar da mesma maneira a Formação Antinha (figura 7.8). 


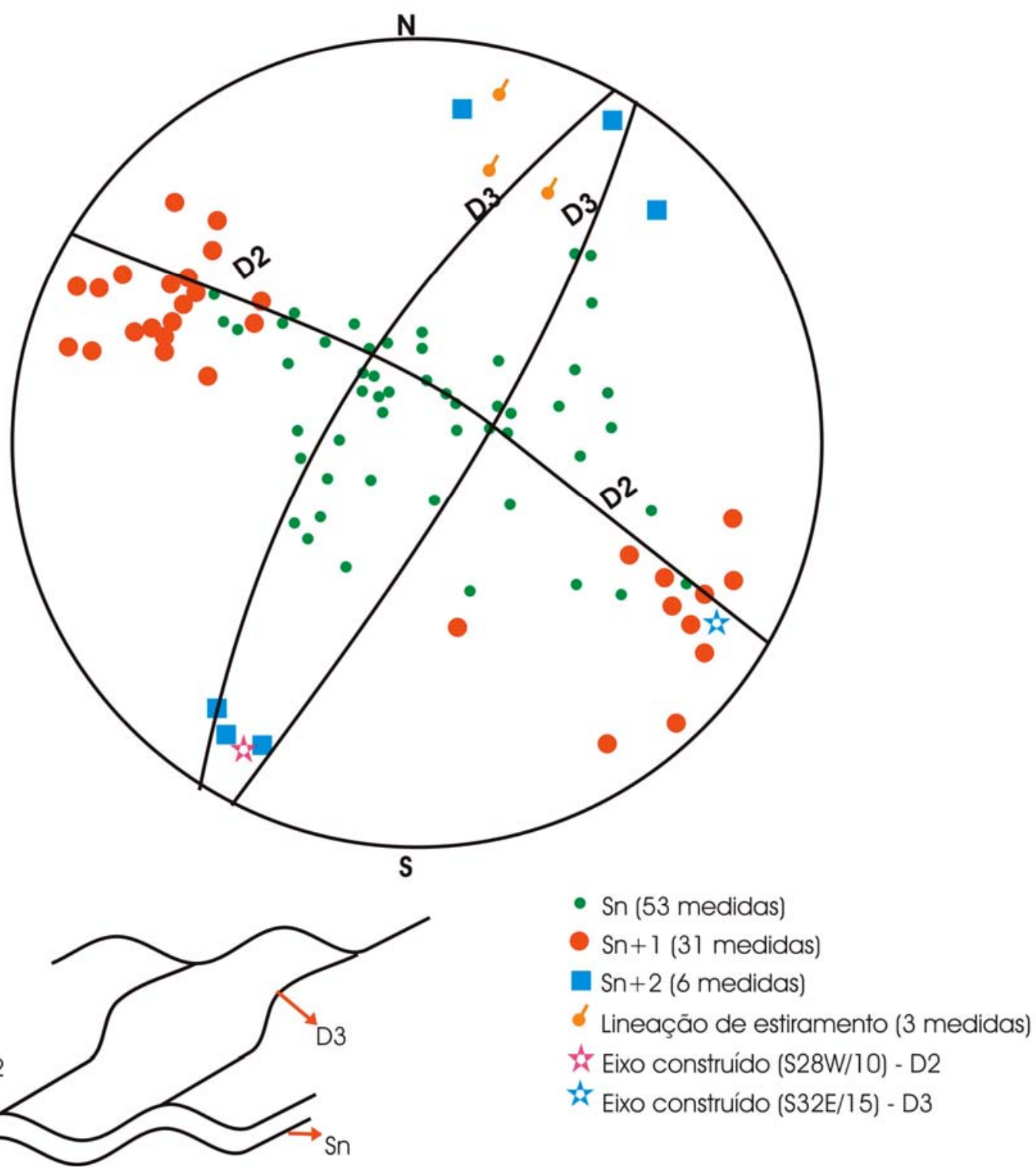

Figura 7.6: Diagrama de Schimidt-Lambert (projeção polar) para a Formação Betara no Setor Ocidental. Mostra Sn de baixo à médio ângulo afetada por um dobramento relativamente cilíndrica (D2) com eixos horizontalizados. Os planos $\mathrm{Sn+1}$ apresentam-se plano-axiais à esses dobramentos. A dispersão observada dos polos de $\mathrm{Sn}$ e $\mathrm{Sn}+1$ somada às observações em campo de ondulações destas superfícies (clivagem ardosiana $\mathrm{Sn}+2$ ) indicam redobramento destas superfícies, com eixos horizontalizados com fracos mergulhos ora para o quadrante NW, ora para o quadrante SE. 


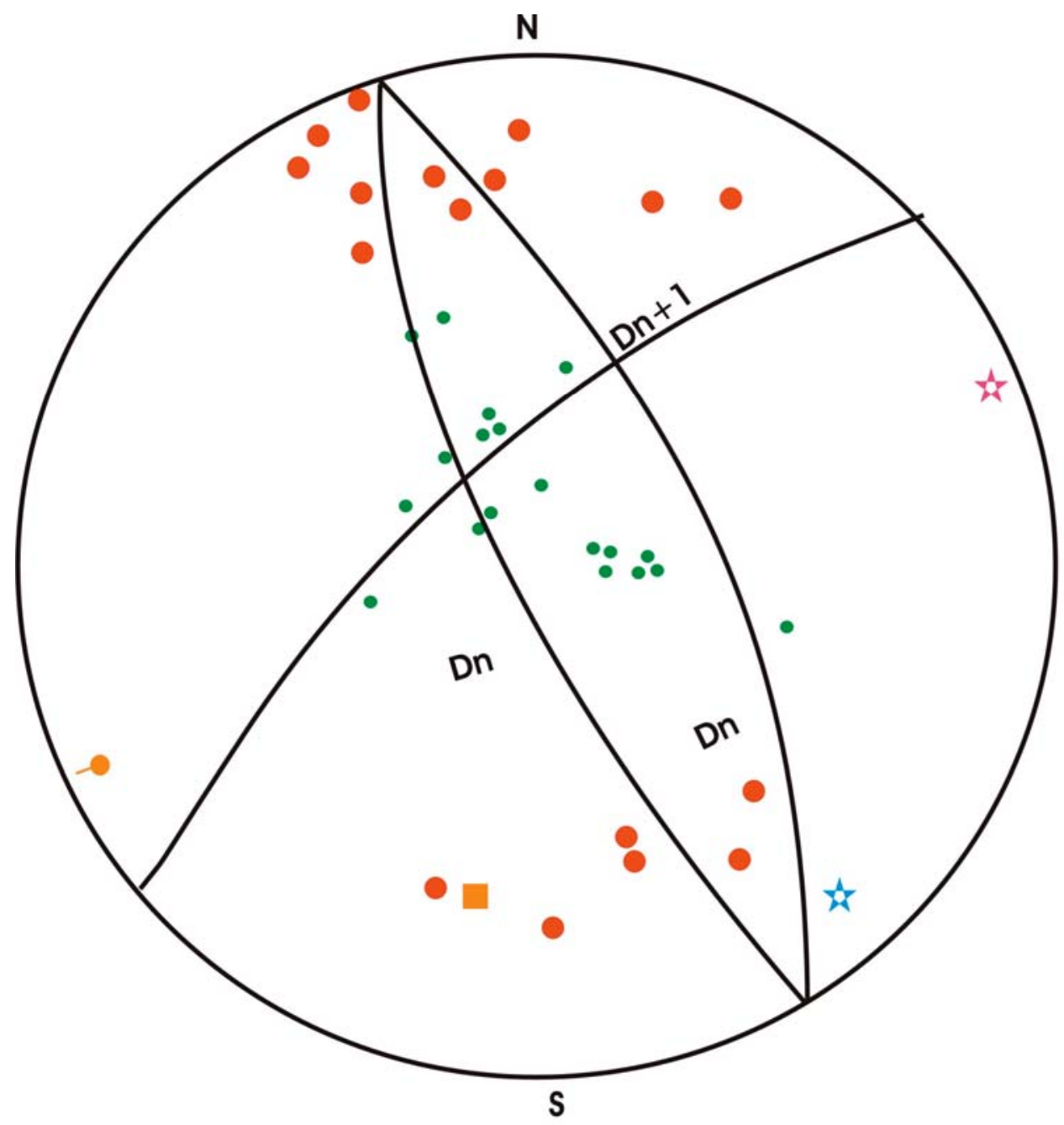

Diagrama de Schimidt-Lambert/ hemisfério inferior projeção polar.

- Sn (19 medidas)

- $\mathrm{Sn+1}$ (17 medidas)

- Lineação de estiramento em Sn

- Plano axial em Sn

S. Eixo construído Dn N70E/12

Eixo construído Dn+1 S52E/15

Figura 7.7: Diagrama de Schimidt-Lambert para a Formação Votuverava. Comportamento estrutural da Formação Votuverava, bastante similar ao observado para a Formação Betara, sugerindo concordância estrutural entre as duas formações (afetadas pelos mesmos eventos deformacionais). 




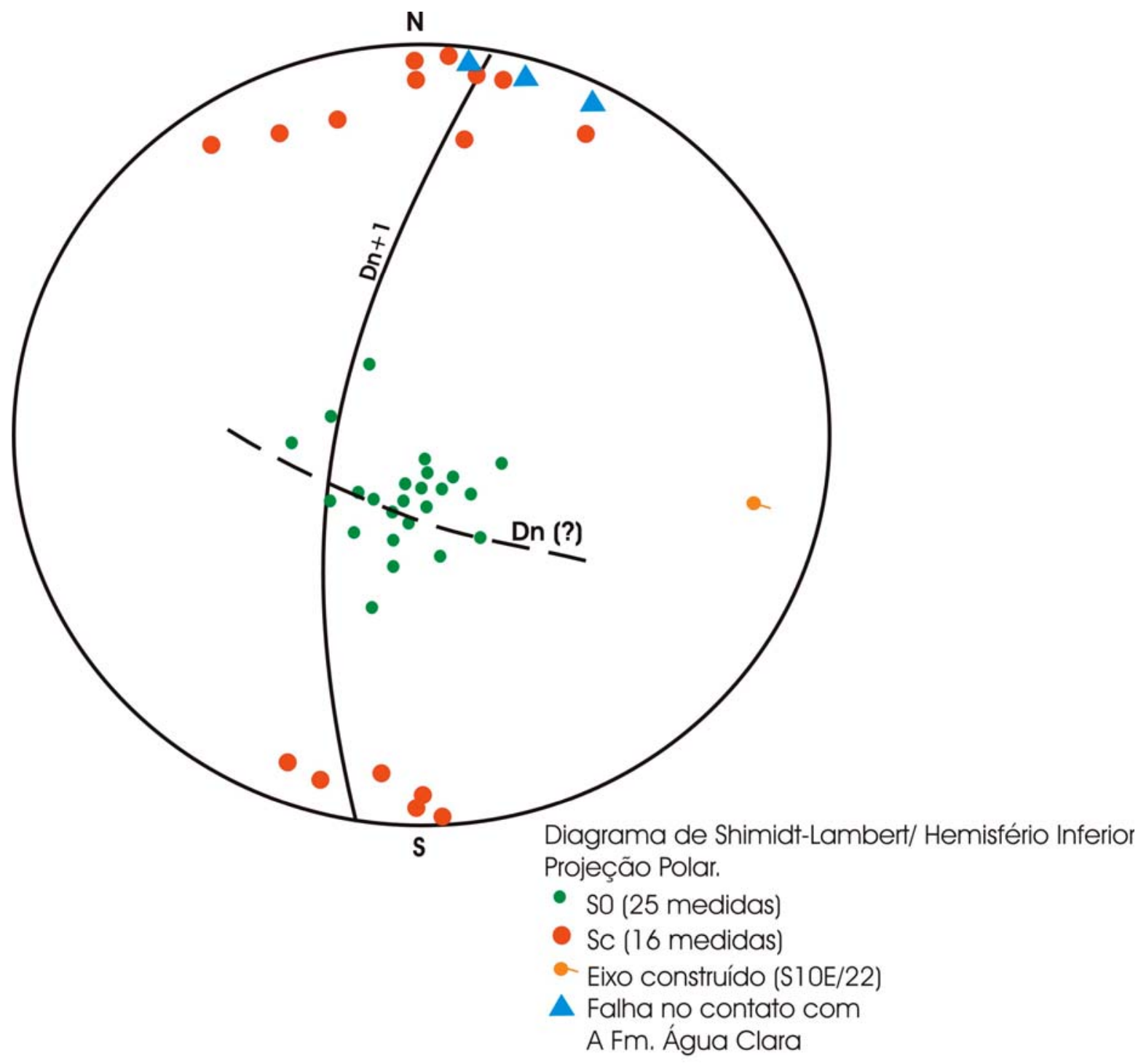

Figura 7.8: Diagrama de Schimidt-Lambert (projeção Polar) para a Formação Antinha. Apesar da pequena quantidade de medidas o estereograma sugere S0 afetada somente pelos dobramentos tardios, também presentes nas Formações Betara e Votuverava.

Os dados relativos à Formação Betara, setor oriental, embora sugestivos de dobramentos tardios de Sn (figura 7.9), não permite uma análise precisa em virtude da pequena quantidade de dados disponíveis. O padrão observado pode representar planos de Sn com padrões aproximadamente E-W e fortes caimentos para norte (na maioria das vezes) bem como para sul (entre $60^{\circ}$ e $70^{\circ}$ ). A dispersão de pontos observada pode ser função de anastomosamentos desta foliação. 


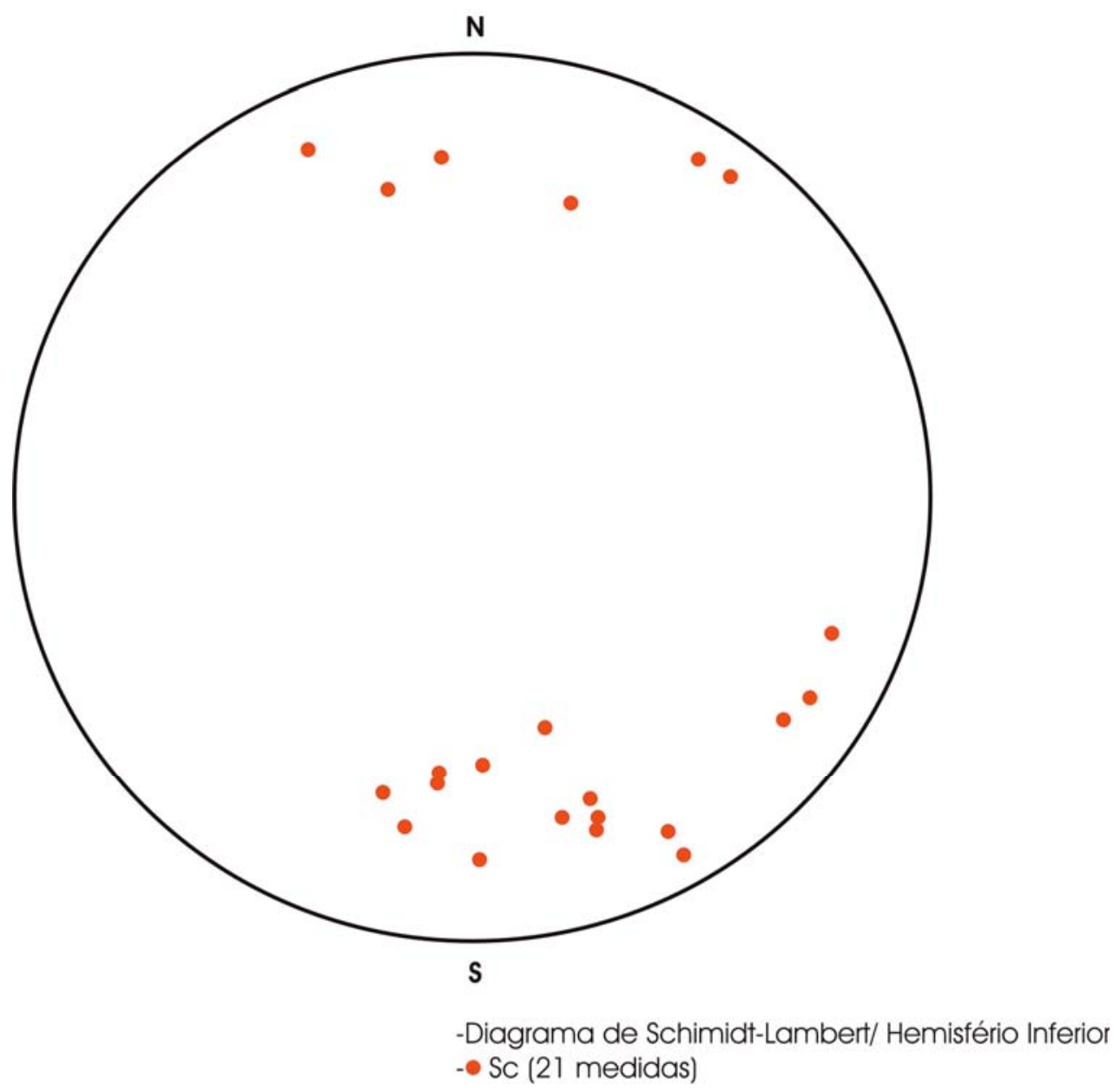

Figura 7.9: Diagrama de Schimidt-Lambert (projeção polar) para a foliação Sc nas zonas de cisalhamento (Formação Betara - Setor Oriental) com direção aproximadamente EW e forte caimento para norte e por vezes para sul $\left(60^{\circ}-70^{\circ}\right)$. A dispersão pode ser relacionada a anastomosamentos internos à zona de cisalhamento. Bastante similar ao que Fiori (1990) e Piekarz (1984) observaram nesta região. Importante ressaltar a semelhança com os padrões $\mathrm{Sn+1}$ observados para a Formação Votuverava, denotando concordância estrutural. 


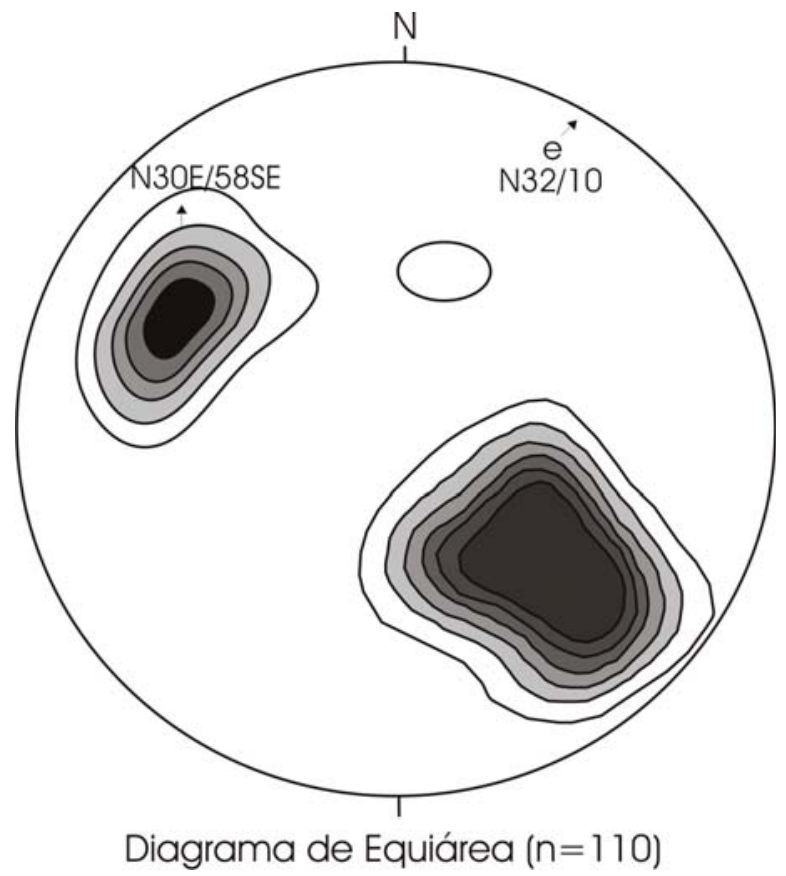

Figura 7.10: Esterograma (densidade dos polos) da Sn (baixo à médio ângulo) nos metassedimentos (Formações Votuverava e Betara) adjacentes às intrusões dos granitos (Cerne, Passa Três e Rio Abaixo) - Retirado de Cury (2003).

A antiforma do Cerne, estudada por Cury (2003), mostra as sequências metavulcanossedimentares da Formação Betara, adjacentes ao maciço granítico com duas concentrações de polos (quadrante SE e principalmente NW) máximos respectivos a N40E/39NW e N 30E/58SE. A guirlanda construída sugere uma dobramento aberto e assimétrico com eixo construído N32E/10 (figura 7.10)

Estes padrões de dobramento são responsáveis pelos grandes antiformas e sinformas regionais com eixos normalmente subhorizontalizados (NE/SW) e planos axiais subverticalizados. Os sistemas transcorrentes rompem essas estruturas, a exemplo da Zona de Cisalhamentos Lancinha, causando nova compartimentação tectônica nesses terrenos, conforme caracterizado por Fiori (1990).

As rochas sienograníticas e granodioríticas que ocorrem no setor centro-sul nas proximidades da Zona de Cisalhamentos Lancinha (Núcleo Betara), apresentam-se intensamente estiradas, lenticularizadas e recristalizadas, obliterando na maioria dos afloramentos observados as foliações anteriores de baixo à médio ângulo presentes nestes litotipos. Tratam-se de superfícies de cisalhamento com características dúcteis à dúcteis- 
rúpteis até completamente rúpteis. Observam-se foliações Ss X Sc e sigmóides de feldspato rotacionados (principalmente nos litotipos granodioríticos), além de sombras de pressão sugerindo movimentação dextral.

Os poucos dados obtidos quando tratados em diagrama de Shimidt-Lambert (projeção polar/hemisfério inferior) apresentam-se distribuídos nos quadrantes NW (predominantemente os sienogranitos) e SE (predominantemente os granodioritos). Apresentam mergulhos relativamente elevados, sugerindo forte influência da Zona de Cisalhamentos Lancinha (figura 7.11). A dispersão observada nestas superfícies no diagrama pode refletir dobramentos tardios.

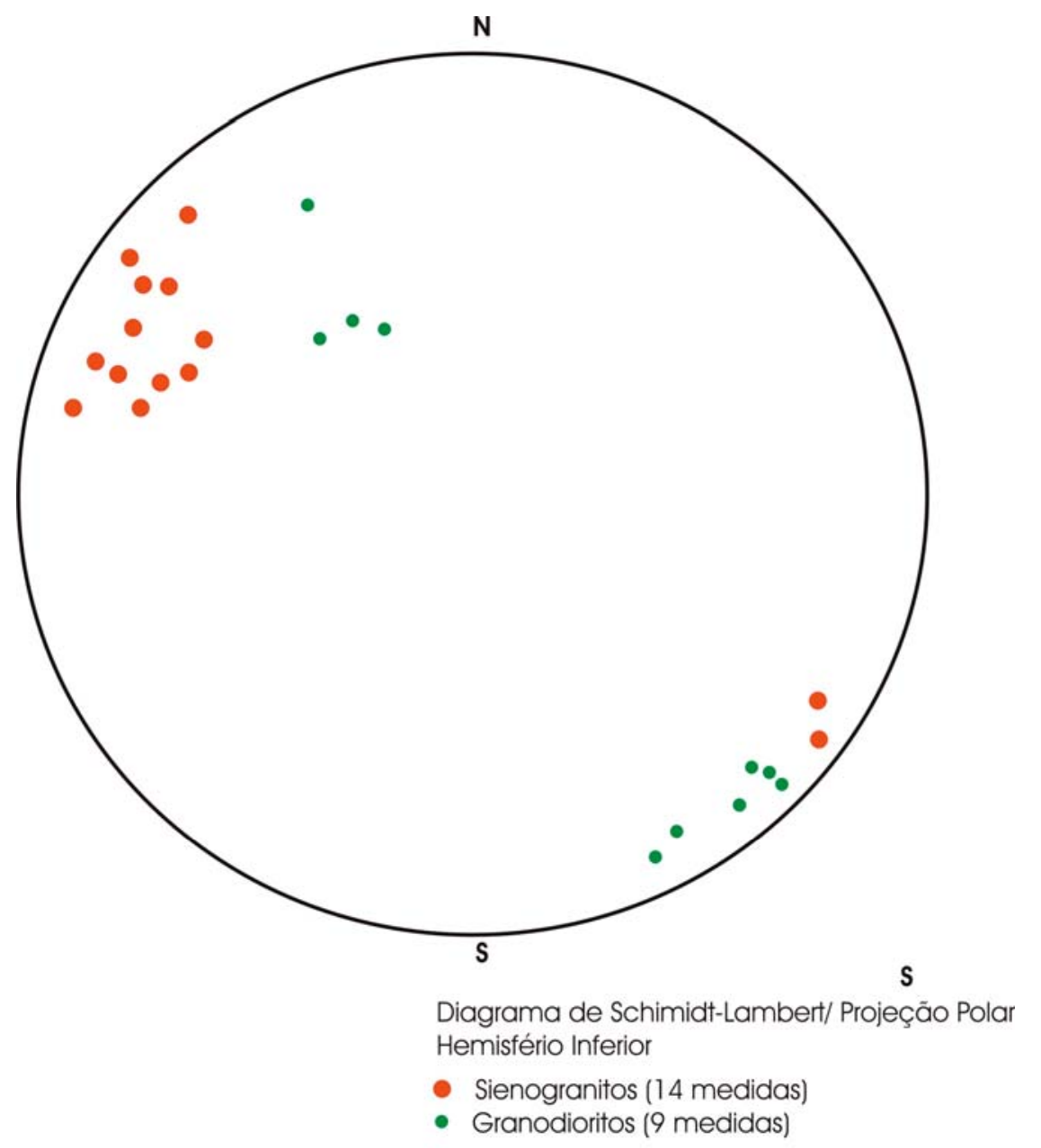

Figura 7.11: Diagrama de Schimidt-Lambert (projeção polar) para os Sienogranitos e Granodioritos do Núcleo Betara. Polos distribuídos nos quadrantes NW (predominantemente) e SE. Superfícies com mergulhos relativamente elevados, sugerindo forte influência da Zona de Cisalhamentos Lancinha. 



\subsection{ESTUDOS GEOCRONOLÓGICOS}

$\mathrm{O}$ estudo geocronológico envolveu principalmente a metodologia U-Pb (zircão) e subordinadamente $\mathrm{Sm}-\mathrm{Nd}\left(\mathrm{T}_{\mathrm{DM}}\right)$ e ${ }^{87} \mathrm{Sr} /{ }^{86} \mathrm{Sr}$ de corpos metabásicos intercalados concordantemente às seqüências metavulcanossedimentares da Formação Betara (filitos da unidade superior). Adicionalmente foram realizadas determinações isotópicas do Núcleo Betara (granodioritos e proto a milonitos e metabásicas associadas a sieogranitos proto a miloníticos). A concentração de zircão dos corpos metabásicos exigiu a coleta de grandes quantidades de material $(20-30 \mathrm{Kg})$ função da baixa concentração desse mineral nesses litotipos.

Outra dificuldade encontrada, refere-se ao reconhecimento em lupa dos zircões nestes litotipos metabásicos, uma vez que apresentam-se normalmente xenomórficos.

\subsection{Análises U-Pb (zircão)}

\subsubsection{Núcleo Betara}

Granodioritos proto a miloníticos

A metodologia U-Pb (TIMS) foi aplicada a cinco frações de zircões de rochas granodioríticas proto a miloníticas que ocorrem na porção centro-sul da região estudada (Pombas/ Conceição dos Correias) pouco a norte da Zona de Cisalhamentos Lancinha.

Os zircões em lupa mostram-se turvos, com hábitos prismáticos, biterminados, com inclusões e poucas fraturas. Três das frações selecionadas (NM-2e, 2d e 2f) mostram zircões com vértices arredondados, enquanto as demais (NM-2a e 2c) apresentam arestas e vértices regulares. Em Diagrama Concórdia (figura8.1) duas das frações do primeiro conjuntos (NM-2d e 2f) apresentaram pontos analíticos que sugerem idades arqueanas ( 2800 Ma), enquanto as duas frações do segundo conjunto (NM-2a e 2c) indicam valores do paleoproterozóico ( $2200 \mathrm{Ma})$ O ponto analítico relativo a uma das frações (NM-2e) posicionou-se bem abaixo dos demais e distante da curva Concórdia, sugerindo desequilíbrio isotópico, possivelmente devido a perdas significativas de $\mathrm{Pb}$. Não podemos, no entanto, descartar a hipótese dos zircões apresentarem bordas de sobrecrescimento (pouco expressivas) relativas ao Neoproterozóico, de difícil caracterização quando utilizada a metodologia convencional (TIMS). De qualquer maneira a distribuição dos pontos 
analíticos em diagramas denota grande complexidade isotópica sugerindo presença de heranças arqueanas ( 2800 Ma) em rochas formadas durante o Paleoproterozóico ( 2200 Ma).

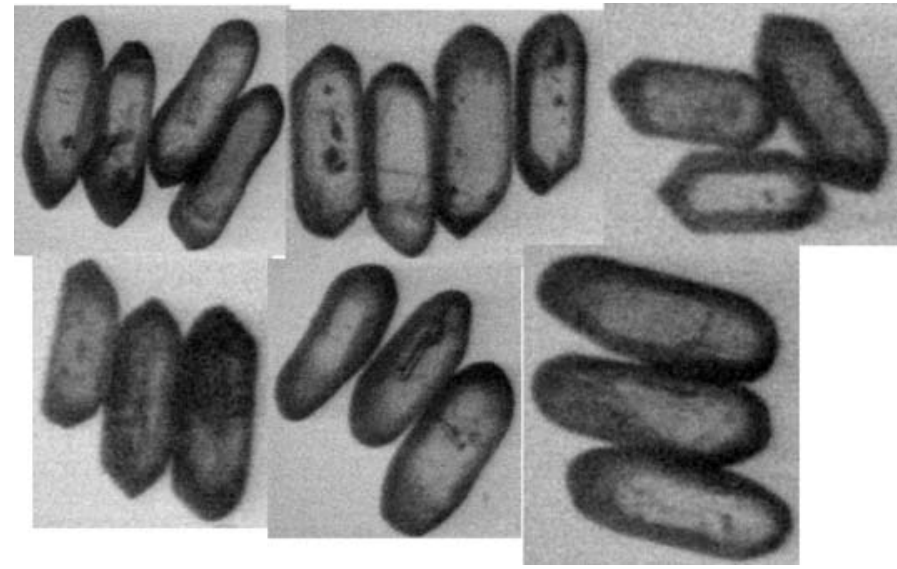

Figura 8.1:Zircões da amostra LBT-13. 


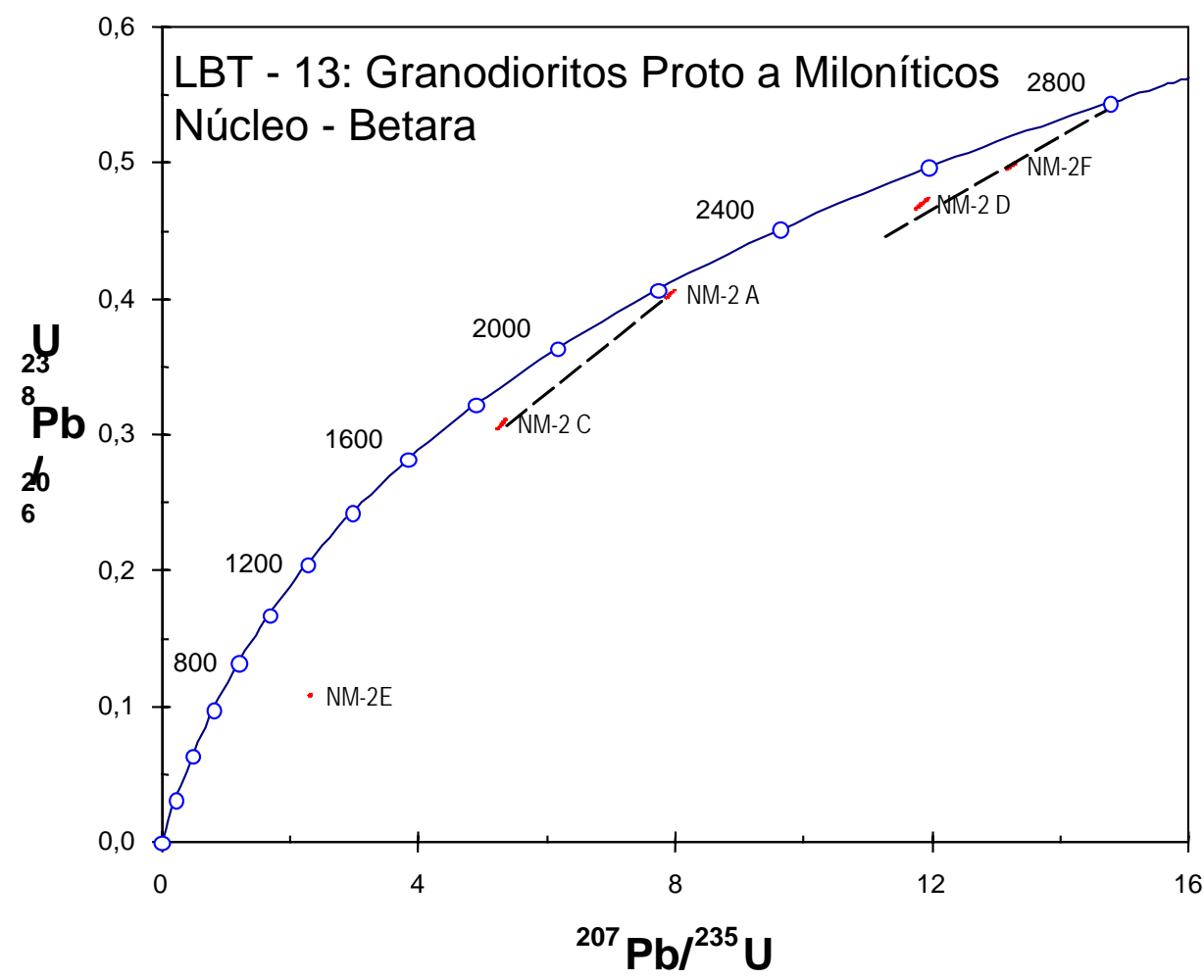

Figura 8.2: Diagrama concórdia para os zircões da amostra LBT-13.

Com a finalidade de melhor caracterizar o quadro geológico obtido através do método U-Pb (TIMS) foram realizadas análises por evaporação de monocristais de zircão diretamente no espectrômetro de massa (EV-TIMS). A análise (EV-TIMS) de um cristal de zircão do primeiro conjunto (biterminações levemente arredondadas) forneceu um patamar com idade de 2766+- 85 Ma. (figura 8.2). Dois zircões do segundo conjunto (prismas regulares) forneceram patamares com idades de 2209+-44Ma. (figura 8.3) e 2187+-39Ma. (figura 8.4 Acrescente-se que tal método não permite normalmente a obtenção de dados relativos a bordas de sobrecrescimento pouco expressivas, devido a queima relativamente rápida e a presença de $\mathrm{Pb}$ comum.

O quadro isotópico apresentado sugere a formação dessas rochas granodioríticas durante o paleoproterozóico ( 2200 Ma) com heranças (núcleos de zircão) arqueanas ( 2800 Ma). Valores Arqueanos foram obtidos através do método Sm-Nd (TDM) que 
acurou idade próxima de 3200 Ma relativa a derivação do manto dos protolitos crustais destas rochas (tabela8.1) amostra do afloramento LBT-13).

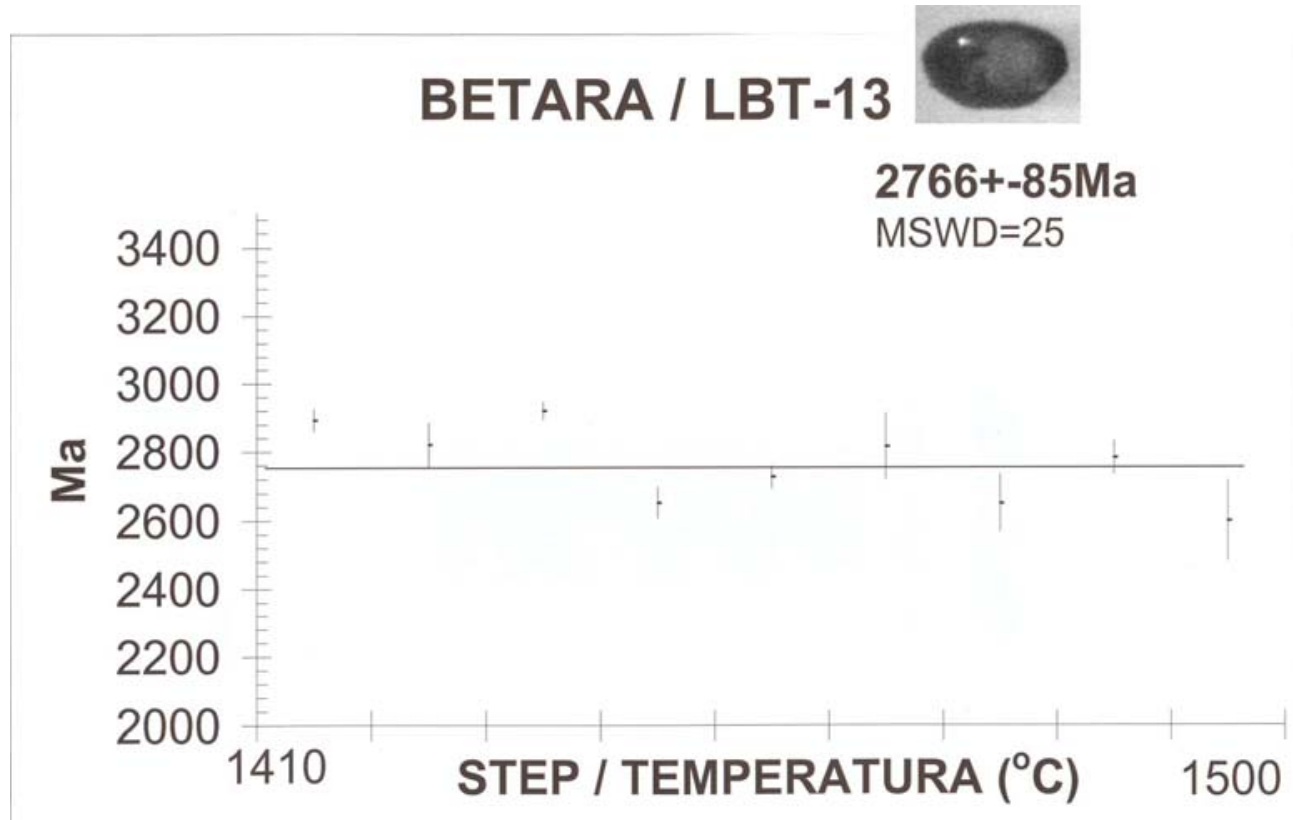

Figura 8.3: Análise EV-TIMS de um cristal de zircão com biterminações levemente arredondadas.

\section{BETARA / LBT-13}

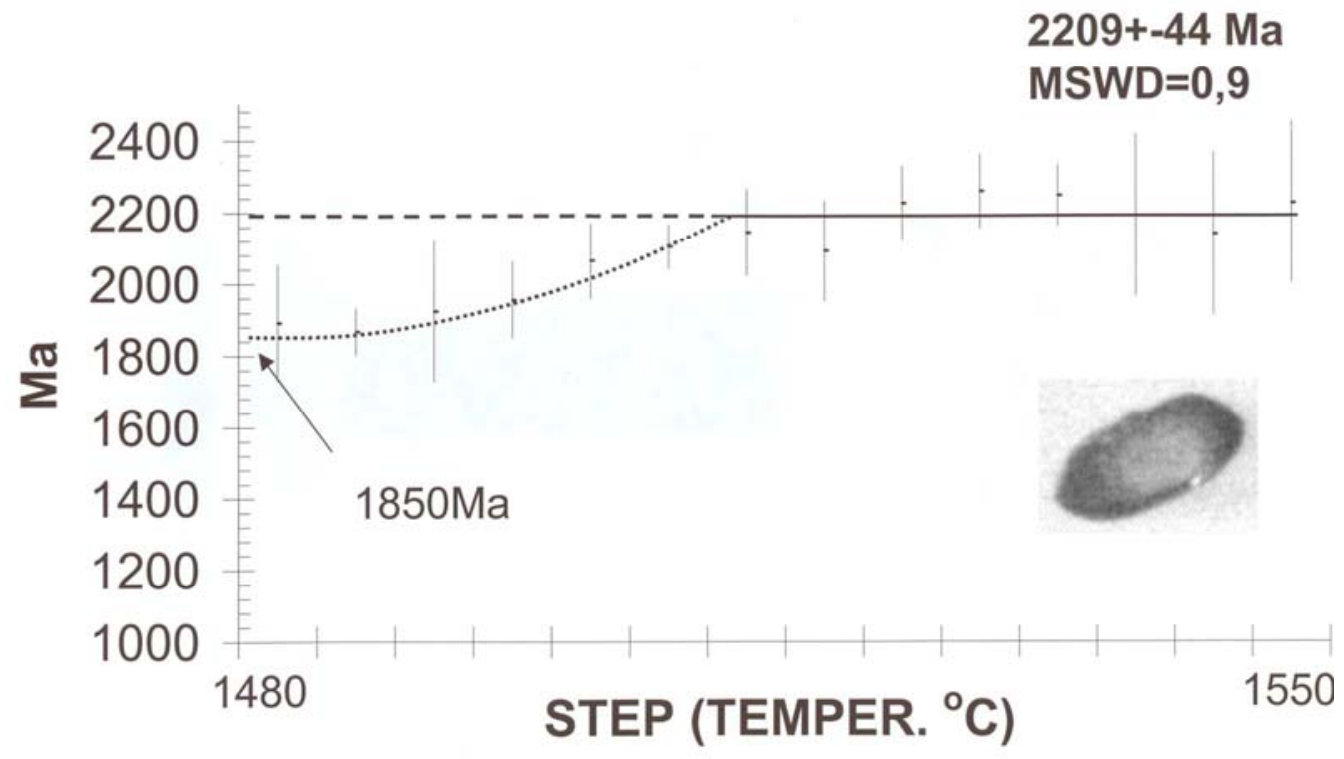

Figura 8.4: Análise EV-TIMS de cristal de zircão prismático regular. 


\section{BETARA / LBT-13}

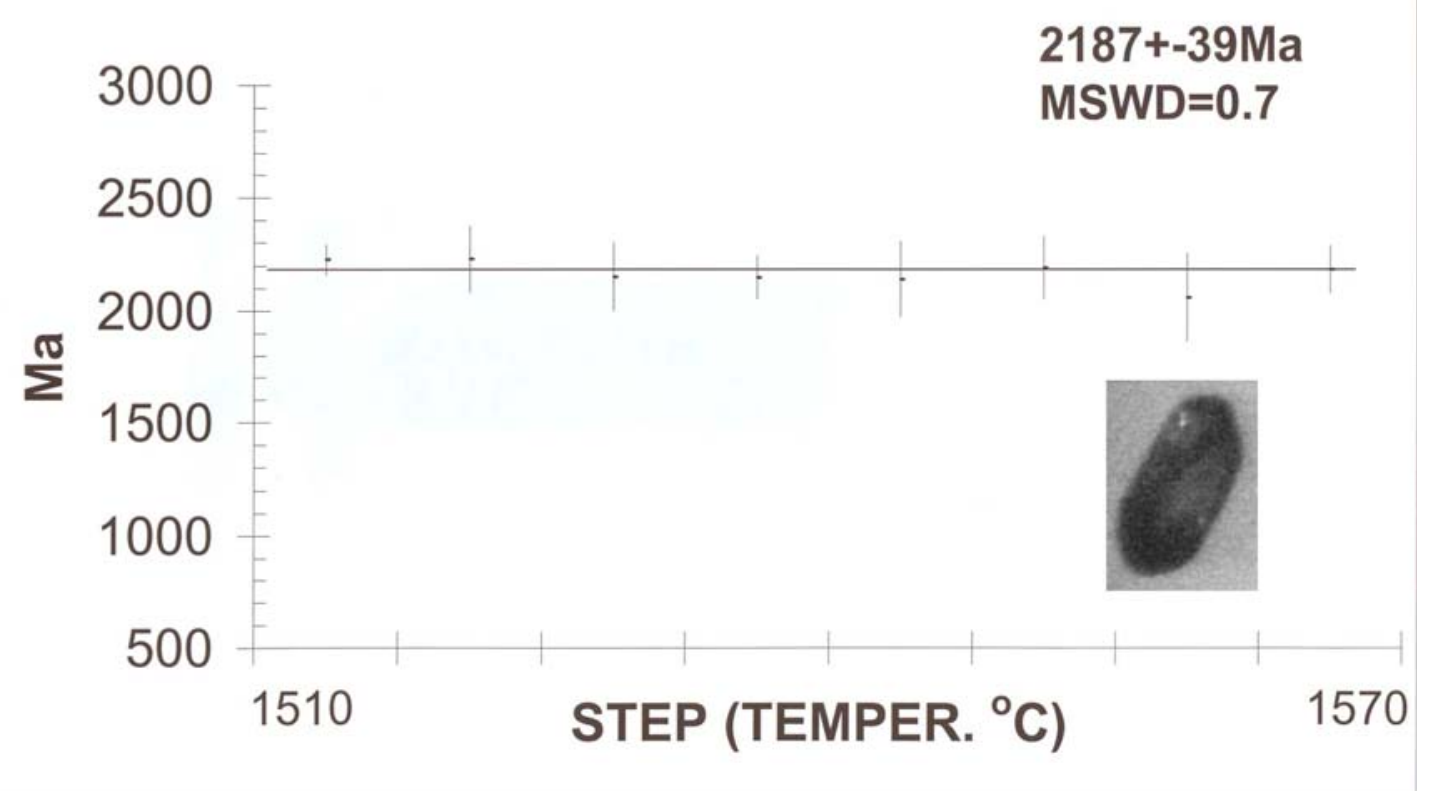

Figura 8.5 Análise EV-TIMS de um cristal de zircão prismático regular.

\section{Rochas Metabásicas Associadas aos Sienogranitos Proto a Miloníticos}

Próximo as localidades de Pombas/ Conceição dos Correias foram observados corpos de rochas metabásicas associados a sienogranitos proto a miloníticos sugerindo processos tanto de mixing como de mingling. Essas rochas de natureza sienogranítica foram analisadas através do método U-Pb (zircão) por Kaulfuss (2001) que obteve idade de 1747+-10 Ma. Rochas similares ocorrem associadas ao Núcleo do Tigre, bem como a sul do corpo granítico Passa Três no âmbito da Formação Betara. Dados isotópicos U-Pb (zircão) revelaram para esses litotipos idades respectivamente de 1772 +- 10 Ma e 1748 +6 Ma. (Cury et al., 2003).

$\mathrm{Na}$ tentativa de melhor caracterizar a evolução geológica-geocronológica deste setor, foram realizadas análises isotópicas U-Pb de cinco frações de zircão de rochas metabásicas associadas aos sienogranitos ( afloramento LBT-12). Foram selecionadas dez populações de zircão com hábitos variados (prismas curtos, biterminados com inclusões e poucas fraturas, fragmentos de prismas, fraturados, prismas longos, biterminados com inclusões e fraturas e cristais xenomórficos), conforme ilustrações anexas (figura 8.6). Oito das frações analisadas incluindo diferentes populações de zircões, concentraram-se 
próximas a curva concórdia, enquanto duas (prismas longos, biterminados e fragmentos de zircões) distribuíram-se em posições inferiores, relativamente afastadas da curva concórdia (figura 8.7). $\mathrm{O}$ alinhamento desses pontos define uma discórdia com idades de 1789+- 22 Ma. Tal valor reflete a formação desses zircões e consequentemente destas rochas metabásicas durante o Paleoproterozóico Superior (Estateriano), em épocas bastante próximas as observadas para os sienogranitos proto a miloníticos. Não descarta-se aqui a possibilidade de haver sedimentação relacionada a esse período.

Não foram realizadas análises Sm-Nd $\left(\mathrm{T}_{\mathrm{DM}}\right)$ destes litotipos metabásicos devido ao avançado grau de intemperismo dessas rochas. Dados Sm-Nd $\left(\mathrm{T}_{\mathrm{DM}}\right)$ obtidos por Kaulfuss (2001) em rochas sienograníticas, acusam valores arqueanos

( $2850 \mathrm{Ma}$ ), relacionados a época de diferenciação do manto dos protolitos crustais destas rochas. Os valores negativos obtidos para o $\mathrm{Nd}(\mathrm{da}$ ordem de -8$)$ refletem o longo período de residência crustal dos protolitos destas rochas sienograníticas.

Tais idades relativas ao paleoproterozóico superior, obtidas em rochas com características anorogências, representam um importante marco na região, relacionadas a Tafrogênese Estareriana. Idades do intervalo 1800-1600 Ma, associadas a processos predominantemente extensionais são reconhecidas principalmente ao longo da porção centro-oriental do continente sul-americano (Brito Neves et al., 2005) e devem representar importantes cicatrizes associadas à ruptura do Supercontinente Atlântica (Roger, 1996) do Paleoproterozóico. 


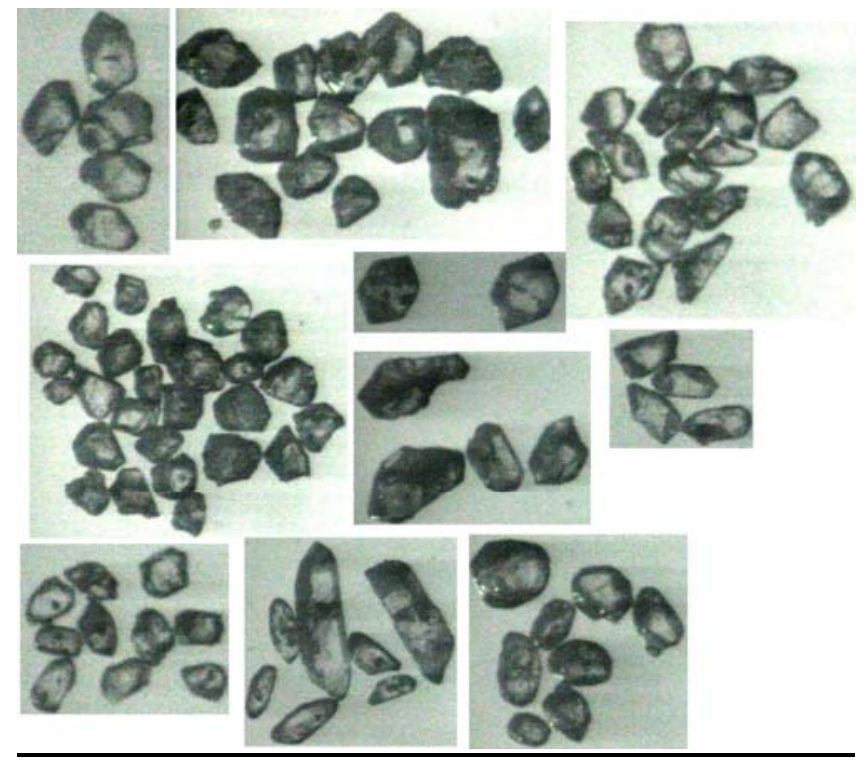

Figura 8.6: Zircões da amostra LBT-12

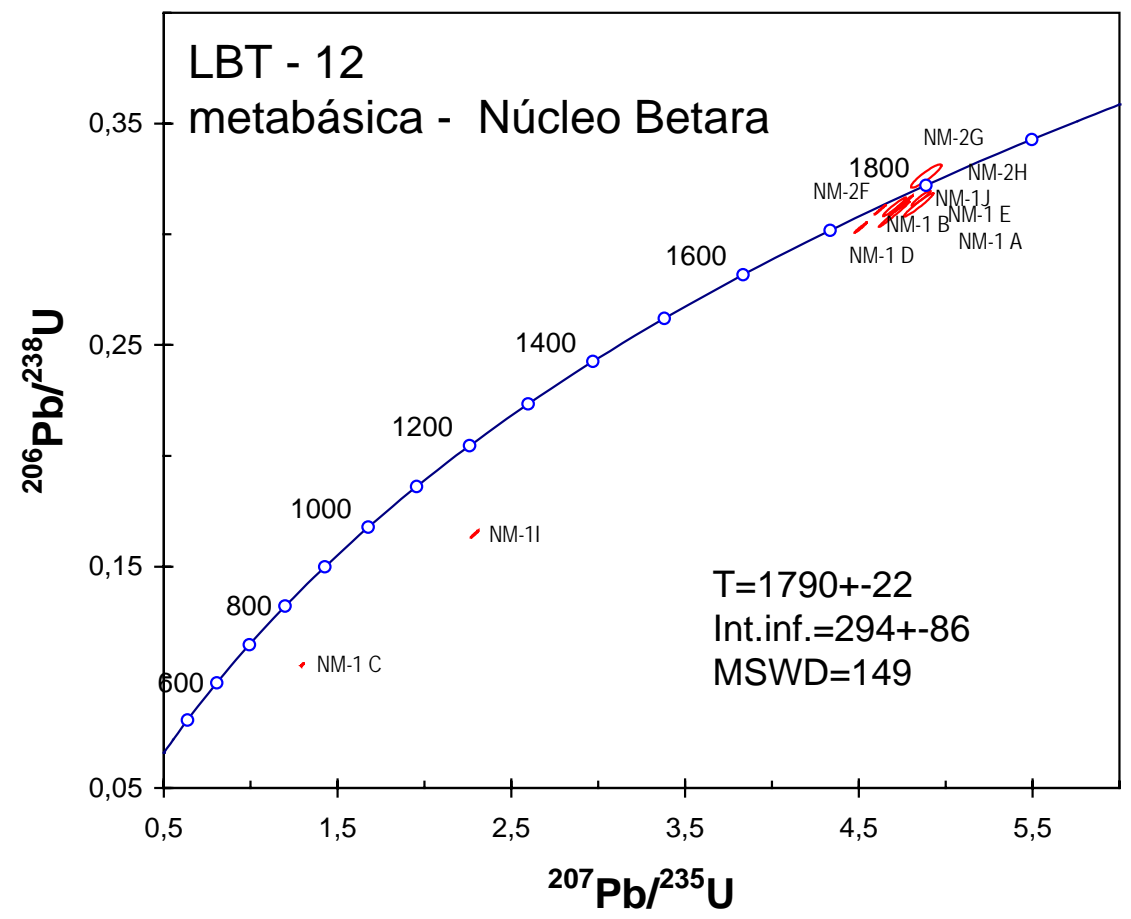

Figura 8.7: Diagrama concórdia para a amostra LBT-12 


\subsection{2 - Formação Betara}

Os estudos isotópicos relativos à Formação Betara concentraram-se em rochas metabásicas que ocorrem intercaladas concordantemente com a seqüência metapelítica (superior).

O corpo de rocha metabásica de número de campo LBT-7 ocorre por uma extensão de cerca de 70 metros ao longo do Rio do Salto (porção oriental estudada), intercalado concordantemente a filitos finamente foliados a rítmicos.

Intercalam-se bandas métricas de rochas pelíticas de cor avermelhada, bastante intemperizadas, contendo pigmentação (vesículas?) brancas. A rocha metabásica se mostra foliada com tonalidade cinza escura a ocre (intemperizada), apresentando granulação fina nas bordas e média a grossa em direção ao centro. Foram selecionadas para análises U-Pb cinco frações de zircão da rocha metabásica de granulação média a grossa. Incluem populações de zircão com hábito pismático, biterminados com inclusões e poucas fraturas (frações com prismas longos e frações com prismas curtos) bem como frações onde os cristais são xenomórficos (figura 8.8). Os dados obtidos, quando tratados em diagrama Concórdia (figura 8.9) distribuem-se relativamente próximos ao intercepto superior indicando idades de 1489+-11Ma. Tal valor relativo ao Mesoproterozóico representa a época de cristalização dos zircões e consequentemente de formação dessas rochas básicas. Tais corpos devem representar sills ou mesmo diques posicionados estratigraficamente na seqüência metapelítica superior. Tal valor deve ser interpretado como mínimo para a deposição da Formação Betara, possivelmente bastante próximo desta. 


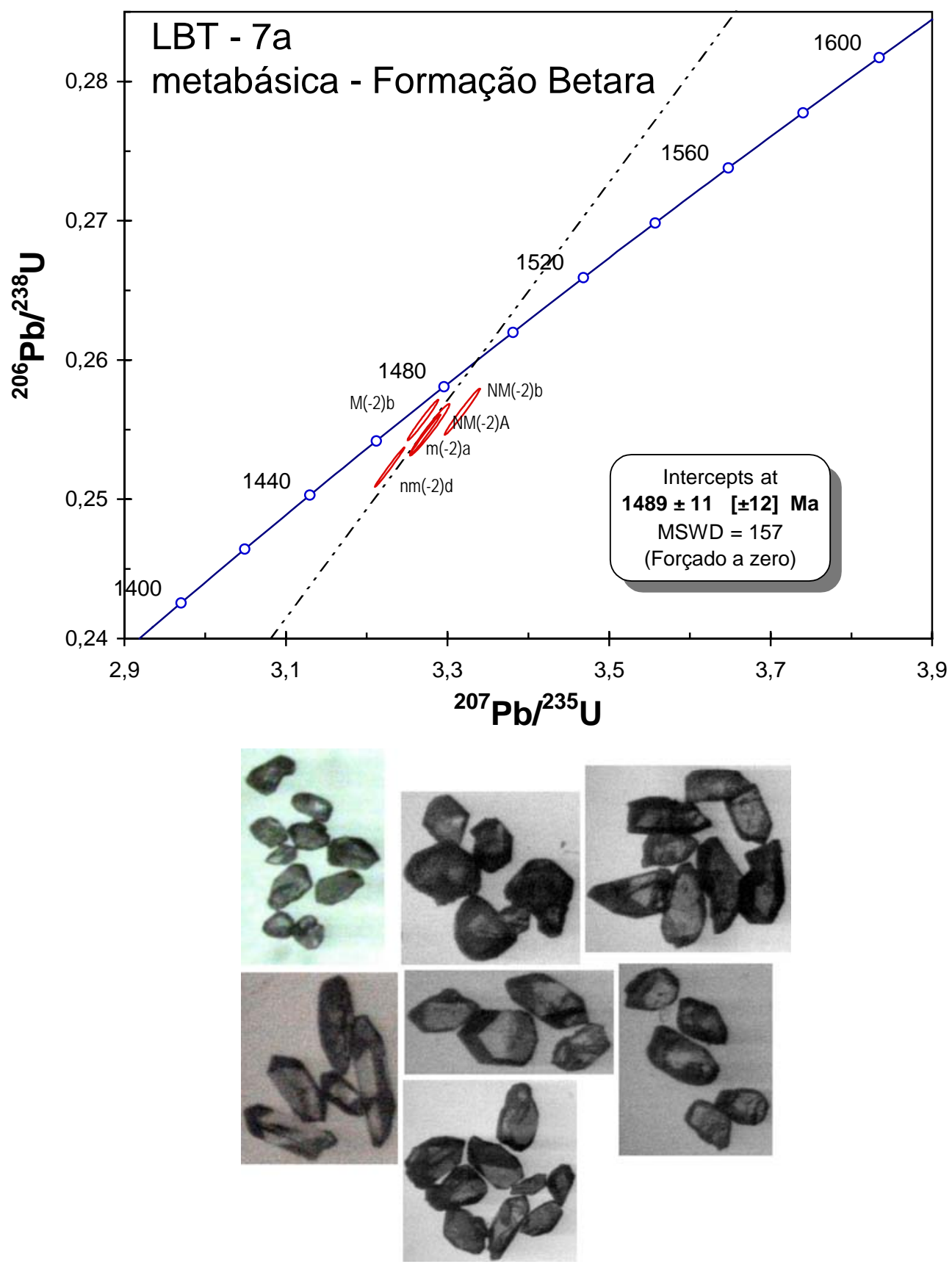

Figura 8.8: Zircões da Amostra LBT-7a

Figura 8.9 Diagrama concórdia para a amostra LBT-7

Outro corpo analisado através do método U-Pb (zircão) refere-se a rocha metabásica de número de campo LBT-9. Ocorre à norte do afloramento anterior, já próximo aos litotipos da Formação Votuverava. Refere-se a rochas relativamente intemperizadas, de tonalidade ocre foliada e de granulação média, intercalada concordantemente a filitos rítmicos. Acrescente-se que cerca de 200-300 metros à norte, já no contato com os filitos 
bandados da Formação Votuverava, ocorrem rochas metabásicas intensamente xistificadas, talco-xistos e milonitos caracterizando o contato tectônico dessas unidades.

Foram selecionadas seis populações de zircão da amostra LBT-9, que incluem prismas longos com vértices arredondados, contendo inclusões e fraturas, fragmentos de prismas irregulares e fraturados, cristais com hábitos esféricos, bem como, cristais xenomórficos (figura 8.10). formas esféricas) e 1475+- 10Ma (zircões xenomórficos). Ocorrem ainda pontos analíticos distantes da curva Concórdia, representantes de zircões prismáticos com vértices arredondados, bem como, de fragmentos de zircão.

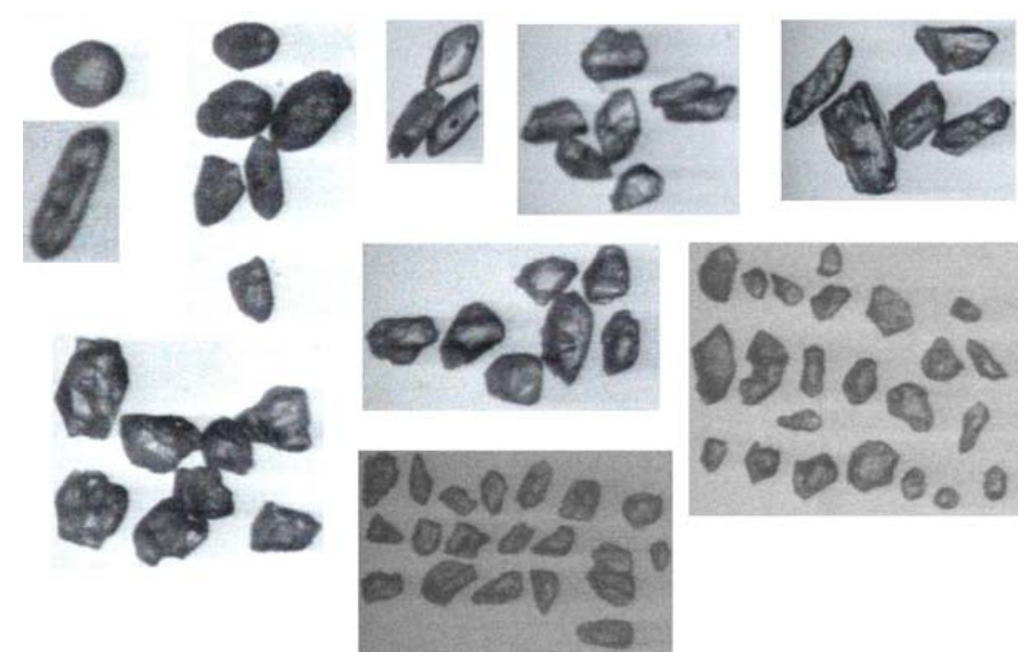

Figura8.10: Zircões da amostra LBT - 9. 


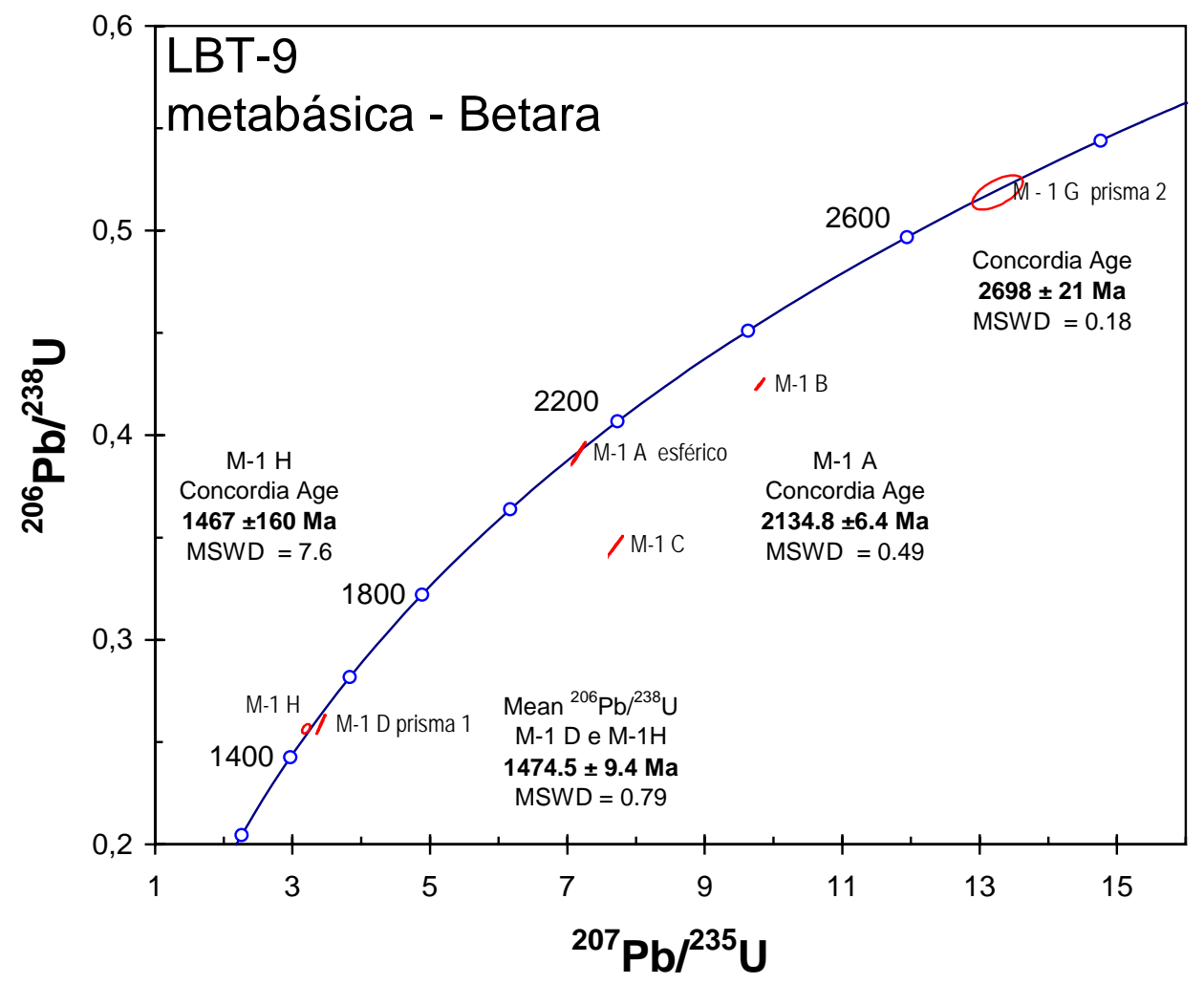

Figura 8.11 : Diagrama Concórdia para a amostra LBT-9.

Os dados obtidos mostram-se bastante dispersos em diagrama Concórdia (figura 8.11), contendo zircões concordantes em 2698+- $21 \mathrm{Ma}$ (fragmentos de prismas irregulares e intensamente fraturados), 2135+-7 Ma. (zircões arredondados e com

Acredita-se que os cristais com hábitos prismáticos levemente a totalmente esféricos e fragmentos, devam representar zircões capturados de rochas encaixantes, quando da colocação do corpo básico. Refletem idades relacionadas a um possível embasamento (infra-estrutura da Formação Betara), ou mesmo de seqüências metavulcanossedimentares inferiores à Formação Betara (zircões detríticos associados à fontes de embasamento). Vale ressaltar que tais valores do Arqueano e Paleoproterozóico, se mostram relativamente similares aos observados para o Núcleo Betara (granodioritos proto a miloníticos) porção centro sul da área estudada (LBT-13). Os cristais xenomórficos, por outro lado, típicos de rochas básicas, devem indicar épocas relacionadas a formação deste corpo metabásico. 
O valor obtido relativo ao mesoproterozóico (1475+-10Ma) se mostra similar ao observado para a amostra de número de campo LBT-07. Tal idade deve portanto representar idades mínimas relacionadas à deposição da Formação Betara.

No setor ocidental (Povinho de São João/ Mineração Tabiporã/ Pinhal) foram selecionados para estudo geocronológicos dois afloramentos de rochas metabásicas intercaladas a filitos da seqüência superior da Formação Betara.

No primeiro (LBT-17), essas rochas apresentam tonalidades ocre à cinza esverdeadas, granulação média, denotando fraturamento. A escassez, ou mesmo ausência de zircões nestes litotipos, não permitiu sua datação. A ocorrência de poucos cristais xenomórficos (passíveis de serem zircões) dissolveram quando tratados com HF à quente, em microondas (algumas horas), denotando não tatarem-se de cristais de zircão.

No segundo afloramento (LBT-20), representado por um pequeno corpo de rocha metabásica cinza esverdeada, de granulação fina à média, intensamente foliado, os zircões apresentaram hábitos variados (prismas) com diferentes dimensões e vértices arredondados, fragmentos de prismas irregulares, intensamente fraturados e cristais com hábitos esféricos (figura 8.12). Foram realizadas análise U-Pb em treze populações de zircões, envolvendo as variedades acima descritas. Estes dados quando tratados em diagrama Concórdia (figura8.13) apresentaram-se bastante dispersos sugerindo idades arqueanas ( 2800 Ma e $2500 \mathrm{Ma}$ ) e ao paleoproterozóico (2130Ma.). Acrescente-se ainda que algumas populações posicionaram-se afastadas e abaixo das idades de 2000Ma definidas pela curva concórdia. Os hábitos dos zircões e sua grande dispersão em diagrama Concórdia sugere tratarem-se de zircões capturados de encaixantes quando da colocação do corpo metabásico. Refletem, possivelmente como no caso de zircões similares coletados da amostra LBT-9, idades relacionadas a infra-estrutura da Formação Betara (embasamento), ou mesmo de seqüências inferiores desta formação (zircões detríticos associados á fontes de embasamento), com valores arqueanos (2800Ma; $2500 \mathrm{Ma})$ e paleoproterozóicos (2130Ma) conforme figura 8.13 . 

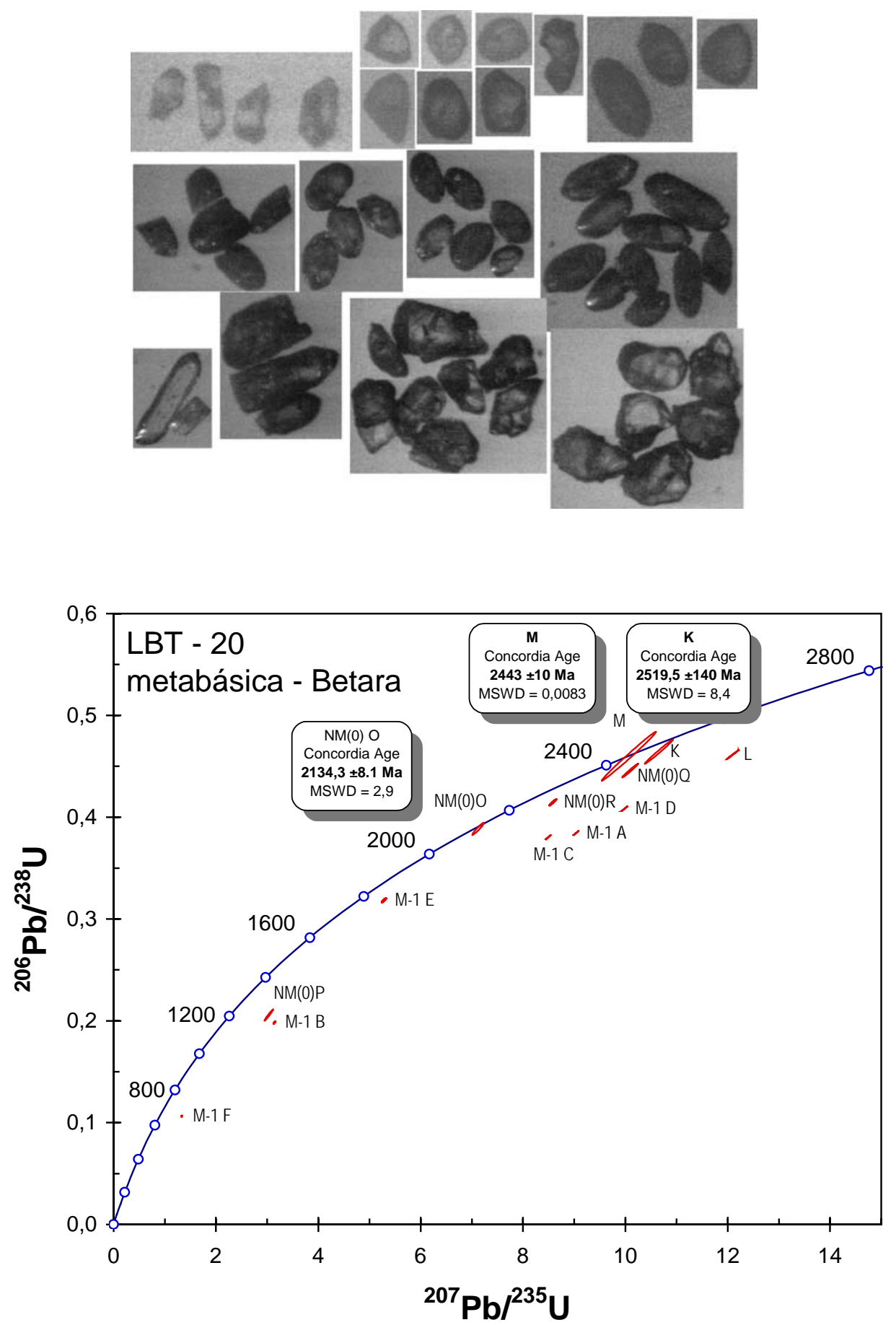

Figura 8.12: Zircões da amostra LBT-20

Figura 8.13: Diagrama Concórdia para a amostra LBT-20

8.2 Análises Sm-Nd e ${ }^{87} \mathrm{Sr}{ }^{86} \mathrm{Sr}$ 
Análises $\mathrm{Rb}$-Sr dos litotipos metabásicos foram tentativamente realizadas conforme tabela 8.2 De um modo geral, os teores de Rb são bastante baixos (0,5 à 4,4 ppm), a exceção da amostra de número de campo LBT-7 (24 ppm), não permitindo precisão desses valores. Os teores de $\mathrm{Sr}$ variam de 140 à $390 \mathrm{ppm}$, e as relações iniciais $\left({ }^{87} \mathrm{Sr} /{ }^{86} \mathrm{Sr}\right)$, quando calculadas para $\mathrm{t}=1400 \mathrm{Ma}$., distribuem-se no intervalo 0,704-0,719, denotando desequilíbrio isotópico. Em diagrama isocrônico estes dados apresentam-se com bastante dispersão, não permitindo o cálculo de idade.

Análises Sm-Nd, realizadas nesses litotipos metabásicos (tabela 8.1) mostram teores de Sm bastante baixos ( 1,0 a 1,6 ppm), a exceção da amostra de número de campo LBT-7B (6,6 ppm). Os valores de $\mathrm{Nd}$, quando calculados para $\mathrm{t}=1400 \mathrm{Ma}$ se mostram positivos, variando de $+2 \mathrm{a}+5$. No diagrama $\quad \mathrm{Nd} \mathrm{x} T$ (figura 8.14) as linhas evolutivas denotam para esses litotipos metabásicos um comportamento relativamente similar a linha de evolução de rochas do manto. Essas linhas evolutivas mostram certo paralelismo a TCHUR, posicionando-se acima da mesma, sugerindo uma evolução do tipo depleted mantle (DM). Duas amostras (LBT-7B e LBT-9B) diferenciam-se um pouco desse padrão, indicando valores de TDM do intervalo de 1450-1400 Ma. Tentativamente foi construído um diagrama isocrônico Sm-Nd (figura 8.14) que sugere alinhamentos com idades variando ente 1500 e 1400 Ma. Tais valores embora imprecisos, indicam épocas de derivação do manto dos protolitos crustais dessas rochas, em épocas bastante próximas a formação das mesmas.

$\mathrm{O}$ diagrama $\quad \mathrm{Nd} \mathrm{X} \quad \mathrm{Sr}$ (figura8.15) mostra grande dispersão dos dados no eixo das abcissas ( $\mathrm{Sr}$ ) denotando o desequilíbrio isotópico nas relações de $\mathrm{Sr}$. Os valores de $\mathrm{Nd}$, por outro lado, se distribuem próximos (pouco acima) dos valores de $\quad \mathrm{Nd}=0$ (eixo das ordenadas do diagrama) comportamento este sugestivo de derivação do manto dos protolitos crustais dessas rochas metabásicas.

\begin{tabular}{|c|c|c|c|c|c|c|c|c|c|c|c|c|}
\hline SPS & No. Campo & Material & $\begin{array}{c}\mathrm{Sm} \\
(\mathrm{ppm})\end{array}$ & $\begin{array}{c}\mathrm{Nd} \\
(\mathrm{ppm})\end{array}$ & ${ }^{147} \mathrm{Sm} /{ }^{144} \mathrm{Nc}$ & ${ }^{43} \mathrm{Nd} /{ }^{144} \mathrm{No}$ & $8_{(0)}$ & $f_{S m / N d}$ & $\mathrm{~T}_{\mathrm{DM}}(\mathrm{Ma})$ & $8_{\text {(TDM) }}$ & $\begin{array}{c}\mathrm{T}_{1} \\
(\mathrm{Ma})\end{array}$ & $8_{(\mathrm{T} 1)}$ \\
\hline 3564 & LBT-17A C13 & $\begin{array}{c}\text { RTOT/Meta } \\
\text { básica }\end{array}$ & 1,387 & 4,068 & 0,2061 & 0,512857 & 4,28 & 0,05 & \#NÚM! & \#NÚM! & 1400,0 & 2,60 \\
\hline 3565 & LBT-17B C13 & $\begin{array}{c}\text { RTOT/Meta } \\
\text { básica }\end{array}$ & 1,336 & 3,678 & 0,2197 & 0,512978 & 6,64 & 0,12 & \#NÚM! & \#NÚM! & 1400,0 & 2,53 \\
\hline 3566 & LBT-20 C13 & $\begin{array}{c}\text { RTOT/Meta } \\
\text { básica }\end{array}$ & 1,644 & 4,967 & 0,2002 & 0,512790 & 2,97 & 0,02 & 3095,8 & 1,61 & 1400,0 & 2,36 \\
\hline 3559 & LBT-7A C 13 & $\begin{array}{c}\text { RTOT/Meta } \\
\text { básica }\end{array}$ & 1,435 & 4,213 & 0,2060 & 0,512825 & 3,65 & 0,05 & \#NÚM! & \#NÚM! & 1400,0 & 2,00 \\
\hline 3560 & LBT-7B C 13 & $\begin{array}{c}\text { RTOT/Meta } \\
\text { básica }\end{array}$ & 6,572 & 28,757 & 0,1382 & 0,512367 & $-5,28$ & $-0,30$ & 1361,1 & 4,88 & 1400,0 & 5,17 \\
\hline 3561 & LBT-9A C13 & $\begin{array}{c}\text { RTOT/Meta } \\
\text { básica }\end{array}$ & 1,030 & 3,001 & 0,2074 & 0,512951 & 6,11 & 0,05 & 2226,3 & 3,06 & 1400,0 & 4,19 \\
\hline 3562 & LBT-9B C 13 & $\begin{array}{c}\text { RTOT/Meta } \\
\text { básica }\end{array}$ & 1,376 & 4,194 & 0,1985 & 0,512894 & 5,00 & 0,01 & 1449,8 & 4,68 & 1400,0 & 4,69 \\
\hline
\end{tabular}


Tabela8.1: com valores obtidos para as análises de $\mathrm{Sm}-\mathrm{Nd}$ das rochas metabásicas da Região do Betara.

Tabela8.2: Valores obtidos para as análises de Rb-Sr das rochas metabásicas da Região do Betara.

\begin{tabular}{|c|c|c|c|c|c|c|c|c|c|c|c|c|}
\hline SPR & No. Campo & Material & $\mathbf{R b}$ & $\mathrm{Sr}$ & ${ }^{87} \mathrm{Rb} /{ }^{86} \mathrm{Sr}$ & ${ }^{87} \mathrm{Sr}{ }^{86} \mathrm{Sr}$ & $\varepsilon_{(0)}$ & $\mathrm{T}_{\mathrm{DM}}(\mathrm{Ma})$ & $\varepsilon_{(\mathrm{TDM})}$ & $\mathrm{T}_{1}$ & $\varepsilon_{(\mathrm{T} 1)}$ & ${ }^{87} \mathrm{Sr}{ }^{86} \mathrm{Sr}$ \\
\hline & & & (ppm) & (ppm) & & & & & & (Ma) & & ( $\mathrm{T}=1400 \mathrm{Ma}$. \\
\hline 3564 & LBT-17A C 13 & $\begin{array}{c}\text { RTOT/Met } \\
\text { abásica }\end{array}$ & 3,73 & 274,35 & 0,0394 & 0,71534 & 153,81 & \#NÚM! & \#NÚM! & 1400,0 & 166,23 & 0,71 \\
\hline 3565 & LBT-17B C13 & $\begin{array}{c}\text { RTOT/Met } \\
\text { abásica }\end{array}$ & 2,65 & 200,87 & 0,0383 & 0,71419 & 137,52 & \#NÚM! & \#NÚM! & 1400,0 & 150,21 & 0,71 \\
\hline 3566 & LBT-20 C13 & $\begin{array}{c}\text { RTOT/Met } \\
\text { abásica }\end{array}$ & 4,42 & 172,79 & 0,0741 & 0,72019 & 222,64 & 38303,8 & 326,43 & 1400,0 & 225,29 & 0,72 \\
\hline 3559 & LBT-7A C13 & $\begin{array}{c}\text { RTOT/Met } \\
\text { abásica }\end{array}$ & 3,37 & 130,43 & 0,0748 & 0,71209 & 107,75 & 22945,5 & 151,58 & 1400,0 & 109,94 & 0,71 \\
\hline 3560 & LBT-7B C13 & $\begin{array}{c}\text { RTOT/Met } \\
\text { abásica }\end{array}$ & 24,04 & 386,85 & 0,1799 & 0,70725 & 38,98 & 2620,5 & $-13,96$ & 1400,0 & 11,00 & 0,70 \\
\hline 3561 & LBT-9A C13 & $\begin{array}{c}\text { RTOT/Met } \\
\text { abásica }\end{array}$ & 0,49 & 169,03 & 0,0083 & 0,71423 & 138,15 & $-24170,2$ & $-158,67$ & 1400,0 & 159,41 & 0,71 \\
\hline 3562 & LBT-9B C13 & $\begin{array}{c}\text { RTOT/Met } \\
\text { abásica }\end{array}$ & 0,88 & 143,89 & 0,0178 & 0,71918 & 208,42 & $-53822,5$ & $-259,40$ & 1400,0 & 227,13 & 0,72 \\
\hline
\end{tabular}




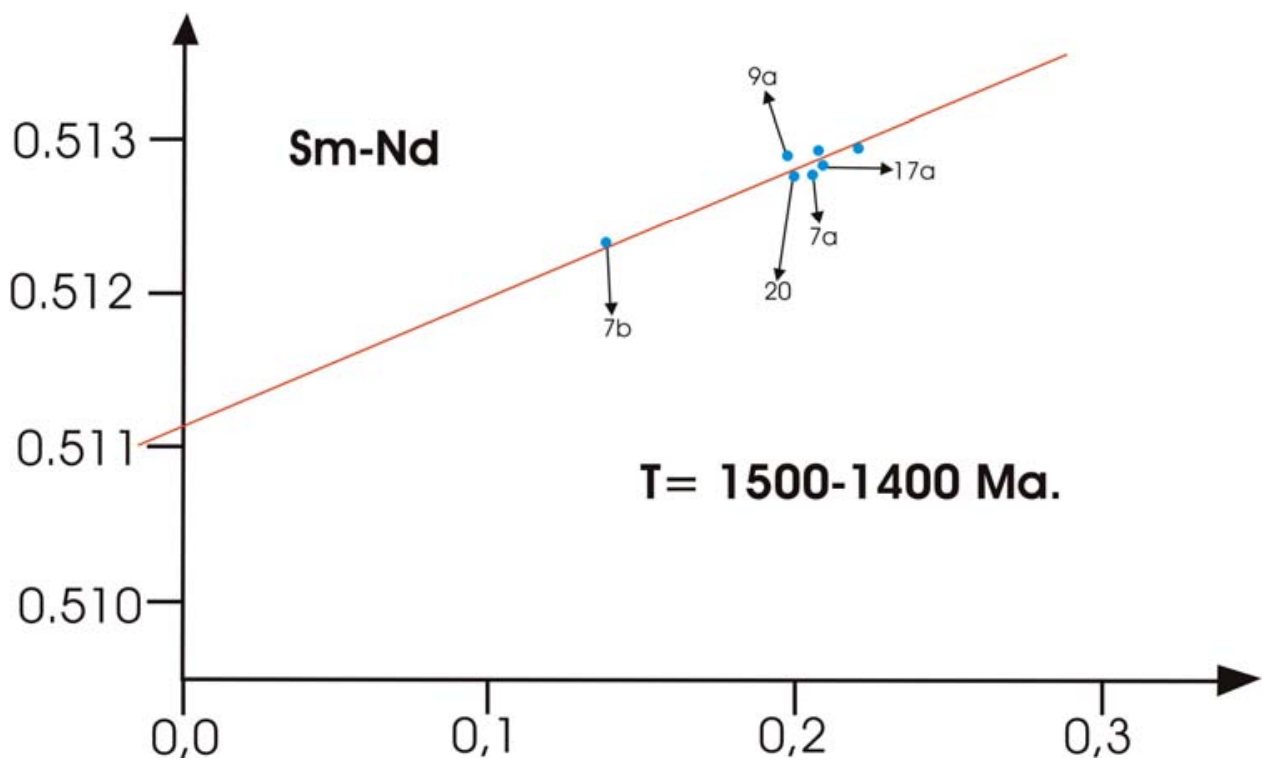

Figura 8.14: Diagrama isocrônico Sm-Nd

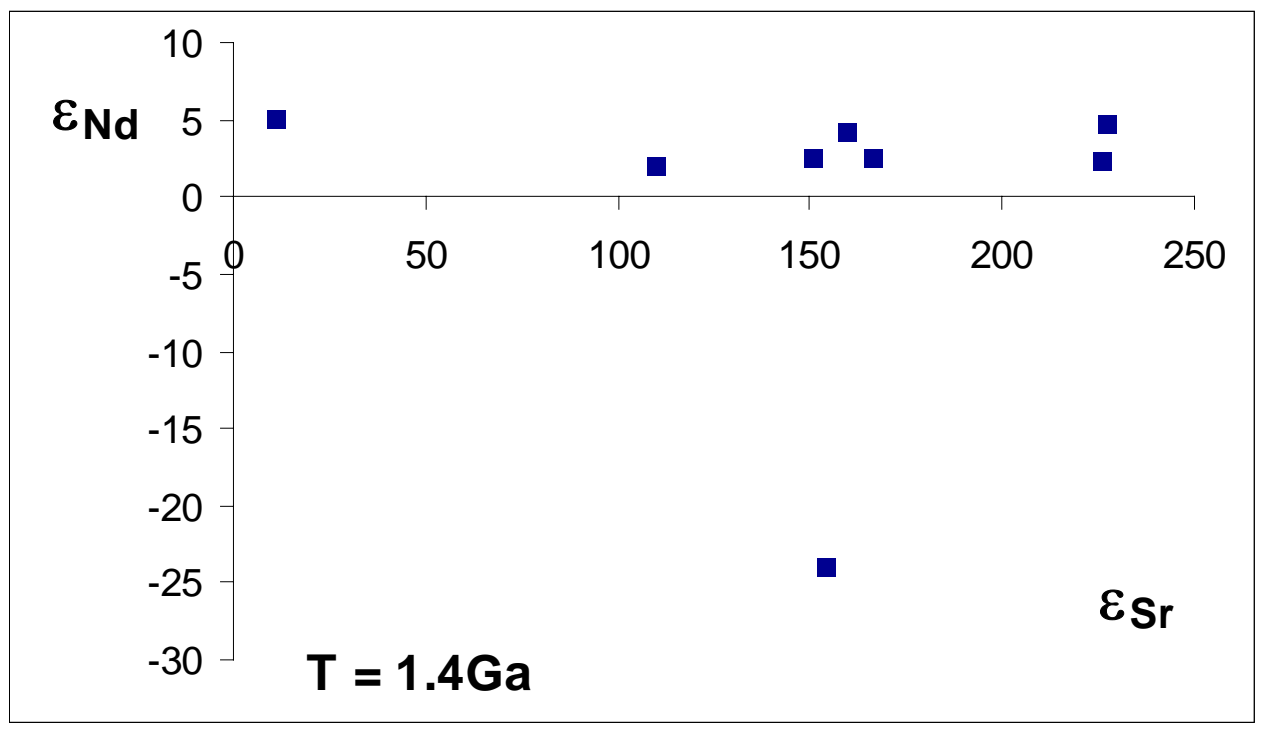

Figura 8.15: O diagrama $\quad{ }_{\mathrm{Nd}} \mathrm{X} \quad$ sr para as rochas metabásicas da Região do Betara. 


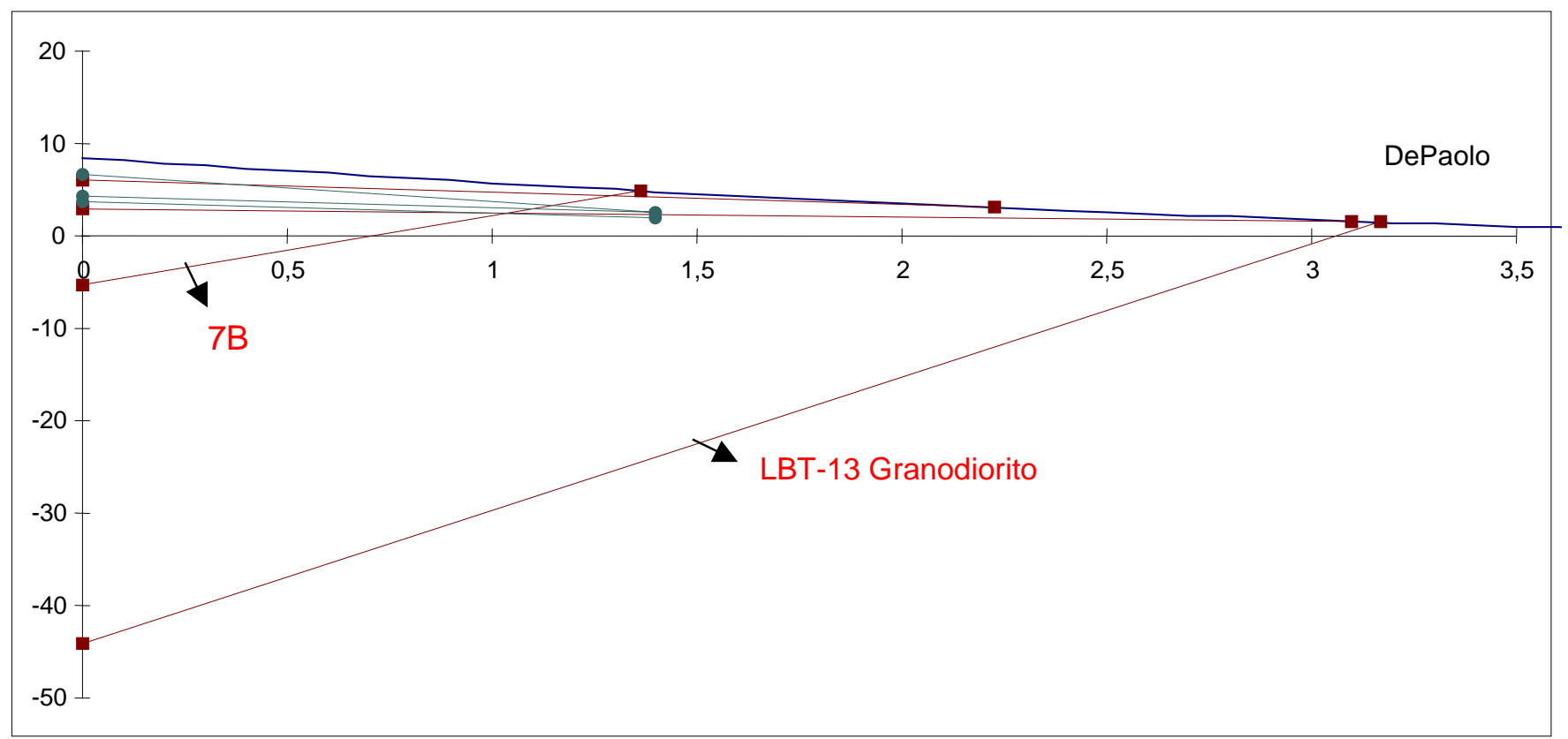

Figura 8.16: Diagrama ${ }_{\mathrm{Nd}} \mathrm{X} T$ para as rochas metabásicas da Região do Betara. 


\subsection{CONSIDERAÇÕES FINAIS}

Nos capítulos anteriores foram abordados aspectos litoestratigráficos, petrográficos, geoquímicos e geocronológicos relativos a região do Betara. Pretende-se aqui realizar uma discussão integrada e comparativa desses dados com objetivo de melhor compreender a evolução tectônica dessa região. Nesse contexto e de modo sucinto os seguintes comentários merecem destaque:

1- Na região centro-sul do Betara, foram reconhecidas rochas granodioríticas proto a miloníticas formadas durante o paleoproterozóico ( 2200 Ma) com heranças (núcleos de zircões) arqueanas ( 2800 Ma). Valores arqueanos $(\sim 3200 \mathrm{Ma})$ foram obtidos através do método Sm-Nd (TDM) indicativos da época de derivação do manto dos protolitos crustais dessas rochas. Estes terrenos são limitados a sul pela Zona de Cisalhamento Lancinha, que baliza o domínio da Faixa Apiaí (à norte) daquele pertencente ao Complexo Atuba (a sul). Neste contexto tectônico, os terrenos granodioríticos proto à miloníticos representam lascas de embasamento, possivelmente relacionadas ao cráton do Paranapanema. Tal correlação, no entanto, não é tarefa fácil, uma vez que as características geológicas acopladas ao padrão geocronológico são bastante similares às observadas para o Núcleo Setuva (Siga Júnior et al., 2006 no prelo) e para o Complexo Atuba ( Siga Júnior et al., 1995 e Sato et al., 2003).

2- Em contato tectônico com os terrenos granodioríticos ocorrem rochas sienograníticas proto a miloníticas, intimamente associadas a rochas metabásicas (mistura de magmas mixing, mingling). Os valores $\mathrm{U}-\mathrm{Pb}$ (zircão) obtidos para os litotipos sienograníticos referem-se ao paleoproterozóico superior (1780 - 1750 Ma; Kaulfuss, 2001 e Cury et al., 2003), similar às idades aqui obtidas para as rochas metabásicas (U-PB, zircão de 1789+-22 Ma). A ocorrência de rochas sienograníticas associadas a rochas metabásicas, com características anorogências, sugestivas de regimes extensionais representa um importante marco na região, relacionado à Tafrogênese Estateriana. Acrescente-se ainda a possibilidade de haver sedimentação associada a esse magmatismo de natureza anorogênica, relacionado a bacias do tipo rift desenvolvidas nesse período. Idades desse intervalo (1800 - $1600 \mathrm{Ma})$ ocorrem no âmbito da Faixa Apiaí, em rochas sienograníticas proto à miloníticas do Núcleo do Tigre, a sul do corpo granítico Passa Três e no setor NE do batólito granítico Três Córregos (Kaulfuss, 2001; Cury et al., 
2003 e Prazeres Filho, 2005). No continente Sul-Americano são reconhecidos ao longo de grande parte de sua porção centro-oriental (Província Borborema, Sistema Espinhaço, Grupo São João Del Rei, Província Tocantins e Faixa Ribeira), conforme discutido em Brito Neves et al. (1995). Esses registros tafrogenéticos, embora relativamente sincrônicos, variam em magnitude e extensão e são na maioria das vezes, caracterizados como rifts crustais com magmatismo de natureza alcalina ou sub-alcalina e sedimentação siliciclástica associada. Devem representar importantes cicatrizes associadas à rupturas de grandes massas continentais aglutinadas durante $\mathrm{o}$ Paleoproterozóico (Supercontinente Atlântica - Rogers, 1996), ou mesmo durante o Paleo-Mesoproterozóico (Supercontinente Columbia; Rogers e Santos, 2002; Zhao et al., 2004).

3- Os estudos geológicos relativos às seqüências metavulcanossedimentares (Formação Betara), em contato tectônico com os terrenos sienograníticos e granodioríticos (Núcleo Betara), permitiram reconhecer da base para o topo três unidades maiores:

- Seqüência metapsamítica basal, representada principalmente por quartzitos puros e subordinadamente quartzitos micáceos, quartzo-filitos, filitos grafitosos, filitos rítmicos e meta-cherts. Destacam-se feições de granodecrescência e a presença de estratificações cruzadas planares de pequeno à médio ângulo, sugestivas de ambientes deposicionais litorâneos.

- Sequência de mármores, cálciossilicáticas e metamargas com metavulcânicas, formação ferrífera e meta-cherts associados..

- Sequência metapelítica superior, onde predominam filitos com intercalações de rochas calciossilicáticas, quartzitos e metabásicas. O metamorfismo predominante é de baixo grau (fácies xisto verde).

Os dados geocronológicos obtidos através do método U-Pb (zircão) referem-se a corpos de rochas metabásicas (possíveis sills ou diques), que ocorrem intercalados concordantemente com a sequência pelítica superior. O estudo petrográficos e geoquímico desses corpos, embora bastante preliminar indica a natureza orto derivada dessas rochas e um quimismo de basaltos subalcalinos sugestivos de ambientes tectônicos distensivos.

As idades obtidas do intervalo de 1500-1450 Ma são aqui interpretadas como mínimas de deposição da Formação Betara, possivelmente próxima desta. Acrescente-se que valores 
arqueanos e paleoproterozóico foram obtidos em zircões de rochas metabásicas que apresentaram hábitos prismáticos com vértices arredondados, zircões esféricos e mesmo fragmentados, sugerindo tratarem-se de cristais capturados, refletindo portanto, acerca do embasamento da Formação Betara.

Valores do intervalo entre 1500-1400 Ma foram obtidos para as seqüências metavulcanossedimentares da Formação Votuverava e Perau (Basei et al., 2006 - no prelo) e Votuverava e Água Clara (Weber et al., 2003), bem como para o Grupo Serra do Itaberaba (Juliani et al., 2000).

O mesoproterozóico representa, portanto, um importante marco relacionado a deposição de grande parte das seqüências metavulcanossedimentares do sul da Faixa Ribeira.

Padrão distinto é observado para as sequências pertencentes à Formação Itaiacoca (1000900 Ma.) e Formação Abapã ( 635 Ma conforme discutido em Siga Júnior et al., 2006), bem como para a Sequência Iporanga e possivelmente Lajeado/Antinha, com idades de deposição relacionadas ao Neoproterozóico ( 600Ma; Hackspacher et al., 2000 e Campanha et al., 2004). Valores do intervalo 650-600 Ma. Foram obtidos para os batólitos graníticos Três Córregos e Cunhaporanga, admitidos como possíveis arcos magmáticos (Prazeres Filho, 2005). Idades do Intervalo 580-560 Ma. referem-se aos corpos graníticos do Cerne, Passa Três, Rio Abaixo, Capivara, Capão Bonito, Correas, Sguário e Carambeí; tardi a pós tectônicos (Cury, 2003 e Prazeres Filho, 2005).

4 - O padrão geológico-geocronológico aliado ao padrão estrutural observado para a região do Betara, sugere que a colocação desses terrenos a níveis crustais superiores tenha ocorrido durante o Neoproterozóico, função de uma tectônica controlada em grande parte por cisalhamentos. Dados isotópicos Ar-Ar e K-Ar obtidos por Kaulfuss (2001) em muscovitas (desenvolvidas em planos Sc de baixo à médio ângulo) de quartzitos pertencentes à Formação Betara, que ocorrem próximos ao contato com os granitóides miloníticos, indicam valores respectivamente de 614+-1,3 Ma. e 604 +- 11 Ma. Caracterizam portanto, épocas relacionadas ao Neoproterozóico, responsáveis pelo resfriamento dessas rochas à isotermas com temperaturas inferiores à $300^{\circ} \mathrm{C}$.

$\mathrm{O}$ padrão estrutural é indicativo de uma tectônica inicial de baixo à médio ângulo, com indicadores cinemáticos que sugerem transporte de NW para SE, em direção ao Complexo Atuba, seguida por sistemas de cisalhamentos transcorrentes e dobramentos tardios, 
similares aos observados por Fiori (1990) para as seqüências metavulcanossedimentares pertencentes ao Grupo Açungui. Essa tectônica é responsável pela aloctonia destes terrenos e conseqüente colocação a níveis crustais superiores. $\mathrm{O}$ atual quadro tectônico, estabelecido no final do neoproterozóico, parece ser o resultado de processos de colagens relacionadas à formação do Gondwana Ocidental. 


\subsection{REFERÊNCIAS BIBLIOGRÁFICAS}

AHRENS, L.H. 1955. Quantitative spectrochemical analysis of silicates : "a scheme of quantitative

$\mathrm{DC}$ arc analysis of the silicate minerals, rocks, soils and meteorites".London : Pergamon, $122 \mathrm{p}$.

ALGARTE, J.P.; KAEFER, L.Q. 1972. Relatório Preliminar da Folha Itararé- SP. Convênio DNPM/CPRM, v.1, 180p.

ALTHOFF, F.J.; FIORI, A.P. 1991. Estruturas macro, meso e microscópicas da porção ocidental da Antiforma do Setuva - PR. Boletim Paranaense de Geociências, 39:p. 51-64.

BAU, M.1996. Controls on the fracionation of isovalent trace elements in magmatic and aqueous systems: evidence from $\mathrm{Y} / \mathrm{Ho}, \mathrm{Zr} / \mathrm{Hf}$, and lanthanide tetrad effect.

BASEI, M.A.S.; SIGA JR., O.; MACHIAVELLI, A.; MANCINI, F. 1992. Evolução tectônica dos terrenos entre os Cinturões Ribeira e Dom Feliciano (PR-SC). Ver. Bras. Geoc., v. 22, no. 2, p. 216-221.

BASEI, M.A.S.; SIGA JR., SATO, K. SPROESSER, W. M. 1995. A metodologia U-Pb na Universidade de São Paulo. Princípios metodológicos, aplicações e resultados obtidos. CPGeo-USP. Anais da Academia Bras. de Ciên. v.67, no 2, p.221-237.

BASEI, M.A.S., SIGA Jr, O.; REIS NETO, J.M., HARARA, O.M.M.; PASSARELLI, C.R.; MACHIAVELLI, A. 1997 Geochronological map of the Precambrian terreins of Paraná and Santa Catarina states, southern Brazil: Tectonic Implications. In: South American Symposiun on Isotope Geology - extended abstracts, Campos do Jordão - SP, Brasil, p. 44-46.

BASEI, M.A.S.; SIGA JR., O.; KAULFUSS, G.A.; CORDEIRO,H.; NUTMAN,A.; SATO, K.; PRAZERES FILHO, H.J.; CURY, L. F.; PASSARELLI, C.R.; HARARA, O.M.; REIS NETO, J. M. 2003. Magmatismo básico mesoproterozóico no Vale do Ribeira: implicações na idade de deposição das seqüências metavulcanossedimentares Perau e Votuverava, Estado do Paraná, Brasil. IV SSAGI, short papers, v.1, p. 501-504.

BASEI, M.A.S.; SIGA JR., O.; KAULFUSS, G.A.; CORDEIRO,H.; NUTMAN,A.; SATO, K.; PRAZERES FILHO, H.J.; CURY, L. F.; PASSARELLI, C.R.; HARARA, O.M.; REIS NETO, J. M. 2003. Geochronology and isotope geology of Votuverava and Perau Meosproterozoic Basins, Southern Ribeira Belt, Brazil. 4 South American Symposiun on isotopes Geology - SSAGI, Salvador, BA, extended abstracts, v. 2, p. 501-504.

BATOLLA Jr., F.; CARVALHO, M.A.S.; COLANERI, S. AGUIAR NETO. 1977. Projeto Leste do Paraná - Folha Curitiba (SG-22-X-D-1): Geologia e Anexos. São Paulo: DNPM/CPRM, v.2. 
BATOLLA Jr., F.; SILVA, A.T.S.F.; ALGARTE, J.P. 1981. O pré-Cambriano na região sul-sudeste do Estado de São Paulo e região este-nordeste do Estado do Paraná. In: Simpósio Regional de Geologia, 3. Atas... São Paulo, SBG, v. 1, p. 94-108.

BESWICK, A. E.; SOUCIE, G. 1978. Acorrection procedure for metassomatism ina na archean greenstone belt. Precambrian Res., v. 6, p. 235-248.

BIENVENU,P.; BOUGAULT,H.; JORON, J.L., TREUIL, M.; DMITRIEV,L. 1990. MORB alteration: Rare-earth element/non rare-earth hygromagmaphile element fractionation. Chemical Geology, Amsterdam, Netherlands, v. 82, p. 1-14.

BIGARELLA, J.J.; SALAMUNI, R. 1956. Estudos preliminares na Série Açungui VII: algumas estruturas singenéticas nos dolomitos da Formação Capiru. Arq. Biol. Tecn., Curitiba, p. 11-197.

BIGARELLA, J.J.; SALAMUNI, R. 1958. Estudos preliminares na Série Açungui VIII: A Formação Votuverava. Inst. Hist. Nat. Geol., Curitiba, 6p. (Boletim 2)

BIGARELLA, J.J.; SALAMUNI, R. 1967. Geologia do pré- Devoniano e intrusivas subsequentes da porção oriental do Estado do Paraná. Bol. Par. Geoc. 23-25:p.1-347.

BIONDI, J.C. (Coord.). 1983. Mapa Geológico da Área do Embasamento do Estado do Paraná; esc.: 1: 250.000. Secret. Est. Ind. Com. MINEROPAR, Curitiba.

BIONDI, J.C. (Coord.). 1989. Mapa geológico do Estado do Paraná; esc.: 1:650.000. MINEROPAR, Convênio DNPM/ Sec. Ciência e Tecnol. E Desen. Econ. Do Estado do Paraná, Curitiba.

BROOKINS, D.G.1989. Aqueous geochemistry of rare earth elements. In: Lipin, R.R.; Mackay, G.A.(Eds). Geochemistry and minralogy of rare earth elements. MAS Reviews in mineralogy, v. 21, p.201-225.

BRAGA, L.S.L.; MESQUITA, M.J.; VASCONCELLOS, E.M.G. 2002. Núcleo Betara: estudo microtectônico da deformação dos metagranitóides do Complexo Meia Lua, Paraná. CONG. BRAS. DE GEOLOGIA, 41. Anais...SBG. p.619.

CAMPANHA, G. A. da C. 1991. Tectônica proterozóica no alto e médio Vale do Ribeira, Estados de São Paulo e Paraná. Tese de doutorado (inédita). São Paulo, IG/USP, 296p.

CAMPANHA, G.A.; BISTRICHI, C.A.; ALMEIDA, M.A. 1987. Considerações sobre a organização litoestratigráfica e evolução tectônica da Faixa de Dobramentos Apiaí. In: SIMP. SUL- BRAS. GEOL., Atas... Curitiba, SBG., v.2, p. 725-742.

CAMPANHA, G.A.C.; SADOWSKI, G.R.; 1998. Tectonics of southern portion of the Ribeira Belt (Apiaí domain). Precambrian Research, 98, p.31-51. 
CARVALHO, P.F.; PINTO, E.A. 1937. Reconhecimento geológico da Série Açungui. DNPM, Rio de Janeiro, Div. Geol. Min., Bol. 71, 29p.

CHIODI FILHO, C. 1984. Contribuição à geologia das regiões sul paulista e leste paranaense, grupos Açungui e Setuva. In: CONGRESSO BRASILEIRO DE GEOLOGIA, 33. Atas... Rio de Janeiro: SBG, v. 5, p. 2394-2406.

CONDIE, K.C. 1989. Plate tectonics \& crustal evolution. ( $3^{\text {rd }}$ Edition). Pergamon Press.

CORDANI, U.G.; BASEI, M.A.S.; SIGA Jr., O.; CITRONO, S.B.; NUTMAN, A. 1999. U$\mathrm{Pb}$ SHRIMP ages of late Proterozoic acid volcanics of southern Brazil; tectonic implications. In: Abstracts with programs. Geol. Soc. Of America, v. 31, n.7, p. 180.

CPRM - Companhia de Pesquisa de Recursos Minerais. 1981. Projeto Integração e Detalhe Geológico do Vale do Ribeira. Relatório Final, São Paulo, Convênio DNPM/CPRM.

CURY, L.F.; KAULFUSS, G.A.; SIGA Jr., O.; BASEI, M.A.S., HARARA, O.M.M.; SATO, K. 2002. Idades U-Pb (zircões) de 1,75 Ga em granitóides alcalinos deformados dos núcleos Betara e Tigre: Evidências de regimes extensionais do Estateriano na Faixa Apiaí. Revista do IGc-USP, Série Científica, v.2, p. 95-108.

CURY, L.F. 2003. Geocronologia e litogeoquímica dos stocks graníticos da porção sudeste da Faixa Apiaí, Estado do Paraná. Dissertação de mestrado (inédita). São Paulo, IGc-USP, 125p.

DAITX, E.C. 1996. Origem e evolução de depósitos sulfetados tipo Perau (Pb-Zn_Ag), com base nas jazidas de Canoas e Perau (Vale do Ribeira-PR). Tese de doutorado. Instituto de Geociências, Instituto de Geociências, UNESP. Rio Claro,

DAITX, E.C.; TEIXEIRA,W.; ZANARDO, A.1990. Geologia e geocronologia do metagabro Apiaí, Vale do Ribeira, SP. In: CONGR. BRAS. DE GEOLOGIA, 36. Anais... Natal, SBG. Boletim de resumos, p. 341.

DEER, W.A.; HOWIE, R.A. ; ZUSSMAN, J. 1966. An introduction to the rock forming minerals $-1^{\text {st }}$ Edition. Longman Scientific \& Technical..

DERBY,O. 1878. Geologia da região diamantífera da Província do Paraná, Brasil. Arch. Musc. Nac. Rio de Janeiro, (RJ), 3:p. 86-89.

DIAS, M.F.V.; SALAZAR JUNIOR, O. 1987. Geologia da Sequência Antinha - Grupo Açungui, Paraná. III Simpósio Sul Brasileiro de Geologia, Curitiba, PR. V.2.

Dover, J.h. 1990. Problems of Terrane terminology - Causes and effects. Geology, 1990, 18 , p. $487-488$. 
EBERT, H.D. 1971. Observações sobre as litologias e subdivisão do Grupo Setuva no Estado do Paraná, com sugestões à tectônica geral do Geossinclíneo Açungui. In: CONG. BRAS. GEOL., 25. Anais... São Paulo, SBG. V. 1, p. 131-165.

EBERT, H.D.; HASUI, Y.; QUADE, H. 1988. Aspectos da evolução estrutural do cinturão móvel costeiro da Mina do Perau, Vale do Ribeira- PR, In: CONGR. BRAS DE GEOLOGIA, 35, Anais..., p. 2318-2331.

FASSBINDER, E. 1996. A unidade Água Clara no contexto do Grupo Açungui: um modelo transpressivo de colisão oblíqua no neoproterozóico paranaense. Tese de Doutoramento (inédito). São Paulo, IG/USP, 207p.

FALEIROS, F.M.; CAMPANHA, G.A.C. 2005. Geometria e cinemática do Domínio Curitiba (Complexos Turvo-Cajati e Gnáissico-Migmatítico) na região do Alto Jacupiranguim - Cajati SP. X Simpósio Nacional de Estudos Tectônicos - SNET. Curitiba, v.1, p. 428-431.

FIORI, A. P.; CAMARGO, E.C.; MONASTIER, M.S.; LIMA, R.S. 1984. Lineamentos tectônicos e possíveis mineralizações associados ao Pré Cambriano paranaense. Convênio UFPR_MINEROPAR, Curitiba-PR, Rel. Interno.v.1, 62p.

FIORI, A. P. 1985a (Coord.). Lineamentos tectônicos e possíveis mineralizações no préCambriano paranaense. Paraná. Rel. Conv. UFPR/MINEROPAR, 2v., 261p.

FIORI, A. P. 1985b Estudos geológicos integrados do Pré-Cambriano paranaense. Convênio UFPR/MINEROPAR, Curitiba, 192p., 4 mapas.

FIORI, A. P.; FASSBINDER, E. GOIS, J.R.; FUMAGALLI, C.E. 1987a. Compartimentação tectônica do Grupo Açungui a norte de Curitiba. In: III Simpósio Sul Brasileiro de Geologia, Curitiba, Atas, v. 1., p.183-196.

FIORI, A. P., SALAMUNI, E., FASSBINDER,E. 1987b. Geologia da Região de Bateias Bocaiúva do Sul. In: III Simpósio Sul Brasileiro de Geologia, Curitiba, Atas, v. 2., p.773787.

FIORI, A.P. (Coord.). 1989. Geologia do grupo Açungui na região de Batéias- Bocaiúva do Sul, escala 1: 100.000. Curitiba: Conv. UFPR/MINEROPAR. 251p.

FIORI, A.P. 1990. Tectônica e Estratigrafia do Grupo Açungui a Norte de Curitiba. Tese de Livre Docência (inédita). São Paulo, IG/USP, 261p.

FIORI, A.P. 1991 Tectônica de cavalgamento no Grupo Açungui. In: SIMP. NAC. DE EST. TECT., 3, Atas... São Paulo, SBG/UNESP, 1991, p. 134-136.

FIORI, A.P. 1992. O Grupo Açungui a norte de Curitiba. In: CONG. BRAS. DE GEOLOGIA, 37(Bol. Res. Exp.). São Paulo, SBG. P. 279-280. 
FRITZONS JR., O.; PIEKARZ, G.F.; FALCADE, D. 1982. Geologia e potencial econômico do Grupo Setuva (PR). In: CONG. BRAS. DE GEOLOGIA, 32. Anais... Salvador, SBG. v.3., p. 991-1001.

FUCK, R.A. 1966. Nota explicativa da Folha Geológica de Quero Quero. Boletim UFPR, 19, p.21.

FUCK, R.A.; MARINI, O.J.; TREIN, E. 1967. Contribuição ao estudo das rochas graníticas do Estado do Paraná. Boletim Paranaense de Geociências, v. 23-25, p. 183-221.

GOIS, J.R.; SALAMUNI, E.; FIORI, A.P. 1985. Lineamentos e compartimentos tectônicos do Pré Cambriano paranaense. II Simpósio Sul Brasil. De Geol., Florianópolis, Anais, v. 1, p. 159-171.

GOKHALE, N.W.; GOTHE, N.N. 1978. Chemical distinction of Amphibolittes. Journal of the Geological Society of India, v. 19, n.8.

GRAUCH, R.I. 1989. Rare earth elements in metamorphic rocks. In: Lipin, B. R.; MacKay, G.A.(Eds) - Geochemistry and mineralogy of rare earth elements. MAS Reviews in Mineralogy, v. 21, p. 147-167.

GUIMARÃES, G. B. 2000. As rochas granitóides do Complexo Granítico Cunhaporanga, Paraná. Aspectos Geológicos, geofísicos, geoquímicos e mineralógicos. Tese de doutoramento, IGc-USP, 230p.

HACKSPACHER, P.C.; DANTAS, E.L.; VAM SCHMUS, W.R.; FETER, A. 1997. Terrenos exóticos na Faixa Ribeira, sim ou não? In: Simpósio Regional de Geologia, São Paulo, Atas, v. 1, p. 69-71.

HACKSPACHER, P.C.; DANTAS, E.L.; SPOLADORE; A.; FETTER, A.H.; OLIVEIRA, M.A.F. 2000. Evidence of Neoproterozoic backarc basin developed in the central Ribeira Belt, Southern Brazil: New geochronological and geochemical constrains from the São Roque - Açungui Groups. Revista Bras. de Geoc., v.30, n.1, p. 110-114.

HASUI, Y.; CARNEIRO, C.D.R.; COIMBRA, A. M. 1975. The Ribeira Folded Belt. Revista Brasileira de Geociências, vol. 5, p. 257-266.

HASUI, Y. 1986. Novo modelo geológico do Vale do Ribeira. IPT, Relatório Interno (inédito). $67 \mathrm{p}$.

HASUI, Y.; CREMONINI, O.A.; BORN, H. 1984. O Granito Três Córregos revisado e o Maciço Catas Altas. In: CONG. BRAS. DE GEOLOGIA, 33. Anais... Rio de Janeiro, SBG. v. 5, p. 3023-3031.

HASUY, Y.; HARALY, N.L.E; MIOTO, J.A.; SAAD, A.R.; CAMPANHA, V.A.; HANZA, V.M.; GALLI, V.A.; FRANGIPANI, A. \& PULEGHINI, F. 1989. 
Compartimentação estrutural e evolução tectônica do Estado de São paulo. IPT- São Paulo (relatório interno) v.2, 289p.

HELMANN, P. L.; HENDERSON, P. 1977. Are rare earth elements mobiles during spilitisation? Nature, v. 267, p. 38-40

HELMAN, P.L.; SMITH, R.E.; HENDERSON, P. 1977. Rare earth elemente investigation of the Ceifed outcrop, N.S.W., Australia. Contrib. Mineral. Petrol. V. 65, p. 155-164.

HELMAN, P.L.; SMITH, R.E.; HENDERSON, P. 1979. The mobility of the rare earth elements: evidence and implications from selected terrains affected by burial metamorphism. Contrib. Mineral. Petrol. V. 71, p.23-44.

JICA/MMAJ. 1982. Report on the Geological Survey of Anta Gorda: Phase II. Convênio DNPM/ Metal Mining Agency of Japan.

IRELAND, T.R.; WILLIAMS, I.S. 2003. Considerations in zircon geochronology by SIMS. Reviews in Mineral. And Chemistry, v.53, p.216-241.

JONES,R. (1995). Terranes tectonics: Dificulties associated with the analysis of disrupetd terranes. $5^{\circ}$ Symp. Est. Tectonics, extended abstracts, v.1, p. 49.

JONES, D.L.; HOWELL, D.G.; CONEY, P.J.; MONGER, W.H. 1983. Recognition, caracter and analysis of tectonostratigraphic terranes in westhern North America. Terra Scientific Publishing Company, Tokio, Edited by M. Hashimoto and S. Uyeda, p. 21-35.

KAEFER, L.Q.; ALGARTE, J.P. 1972. Maciço Alcalino do Banhado: estudos preliminares. In: SIMP. REG. DE GEOLOGIA. Atas... Rio Claro, SBG v.I, p. 1-16.

KAULFUSS, G.A. 2001. Geocronologia dos Núcleos de Embasamento Setuva, Betara e Tigre, Norte de Curitiba, Paraná. Dissertação de Mestrado (inédita). São Paulo, IG/USP, $115 \mathrm{p}$.

KAWASHITA, K.; TORQUATO, J.R. 1999. O método ${ }^{40}$ Ar- ${ }^{39}$ Ar. In: Geocronologia Nuclear - Capítulo IV. CPGeo - IGc-USP, separata 392, p.129-156.

KOBER, B. 1986. Whole grain evaporation for ${ }^{207} \mathrm{~Pb} /{ }^{206} \mathrm{~Pb}$ age investigation on single zircons using a double filament source. Contrib. Mineral. And Petrol., v. 93, p. 482-490.

KOSLER,J.; SYLVESTER,P.J. 2003. Present trends and the future of zircon in geochronology: laser ablation ICPMS. Reviews in Mineral. And Chemistry, v.53, p.244275.

KROGH, T.E. 1991, A low contamination method for hydrothermal decomposition of zircon and extraction of the $\mathrm{U}$ and $\mathrm{Pb}$ for isotopic age determinations. Geochim. Et Cosmochim. Acta, v. 37, p. 485-494.

LEAKE, B.E. 1978. Nomenclature of anphibolites. Am Mineral.v. 63, p. 1023-1052 
LUDDEN, J.N.; THOMPSON, G. 1978. Behavior of rare earth elements during submarine weathering of tholeitic basalts. Nature, v. 274, p. 147-149.

MAACK, R. 1947. Breves Notícias sobre a geologia dos estados do Paraná e Santa Catarina. Curitiba. Arq. Biol. Tecn, v. 2, p. 63-154.

MAACK, 1953. Mapa Geológico do estado do Paraná, escala 1:750.000. Curitiba: Instituto de Biologia e Pesquisas Tecnológicas.

MANIESI, V. 1997. Petrologia das Rochas Anfibolíticas das Regiões de Adrianópolis, Campo Largo e Rio Branco do Sul - PR. Tese de Doutorado (inédita). Rio Claro, UNESP, $215 \mathrm{p}$.

MARINI, O.J.; TREIN, E.; FUCK, R.A. 1967. O Grupo Açungui no Estado do Paraná. In: BIGARELlA, J.J.; SALAMUNI, R.; PINTO, V.M. "Geologia do Pré Bol. Paran. Geoc. 23-25: p. 43-104.

MARINI, O.J. Geologia da Folha de Rio Branco do Sul. Rio Claro. Tese de Doutoramento, Faculdade de Filosofia, Ciências e Letras, Rio Claro, SP. 190 p.

MEZGER, K.; KROGSTAD, E.J. 1997. Interpretation of discordant U-Pb zircon ages: $\mathrm{Na}$ evaluation. Journal of Metamorphic Geology, v. 15, p. 127-140.

MONTEIRO, L.V.S.; MARTIN, M.A.B.; JULIANI, C.; CAMPOS NETO, M.C. 1994. Contribução à geologia do Núcleo Betara (PR). In: CONGR. BRAS. DE GEOLOGIA, 38. Bol Resumos Exp... Balneário Camboriú. SBG. v. 2, p. 62-64.

MURATORI, A. 1966. Nota explicativa da folha geológica de Campo Largo. Boletim Paranaense de Geociências, v. 21, p. 1-28.

OLIVEIRA, E. P. 1927. Geologia dos recursos minerais do Estado do Paraná. Serv. Geol. Min. Monogr. 6, Rio de Janeiro, 172 p.

OLIVEIRA, A.I. \& LEONARDOS, O.H. 1943. Geologia do Brasil. Min. Da Agr. Serv. Didático, Rio de Janeiro. v. 2. p. 782.

PEARCE, J.A.; NORRY, M.J. - 1979 - Petrogenetic implications of Ti, Zr,Y, and Nb variations in volcanic rocks. Contrib. Mineral. Petrol. 69: 33-47

PEARCE, T.H. - 1968 - A contribution to the theory of variations diagrams. Contrib. Mineral. Petrol. 19: 142-157

PEARCE, T.H. - 1987 - The identification and assentment of spurious trends in Pearcetype ratio variation diagrams: a discussion of some statistical arguments. Contrib. Mineral. Petrol. 97: 529-534 
PETRI, S.; SUGUIO, K. 1969. Sobreos metassedimentos do Grupo Açungui no extremo sul do Estado de São Paulo. Convênio USP-DAEE, 98p.

PIDGEON, R.T. 1992. Recristalization of oscilatory zoned Zircon: some geochronological and petrological implications. Contrib. Mineral. Petrol., 110, p. 463-472.

PIEKARZ, G. F. 1981. Reconhecimento das unidades correlacionáveis à Seqüência Mineralizada do Perau - Estado do Paraná. In: SIMP. REG. DE GEOLOGIA, 3. Atas... São Paulo, SBG. v.1, p. 148-154.

PIEKARZ, G.F. 1984. Geologia e resultados preliminares de pesquisa mineral do Núcleo Betara da Formação Perau. In: CONG. BRAS. DE GEOLOGIA, 33. Anais... Rio de Janeiro, SBG. v.8, p. 3682-3696.

PONTES, J. B. 1981. Investigações e potencialidades econômicas da Formação Água Clara (PR). Mineropar, Curitiba, 34 p.

POPP, J.H.; ANGULO, R.; BIGARELLA, J.J. 1979. Geologia. In: Região Metropolitana de Curitiba, Recursos Naturais, Folha de Ouro Fino. COMEC. 30p.

PRAZERES FILHO, H. J. 2000. Litogeoquímica, Geocronologia (U-Pb) e Geologia Isotópica dos Complexos Graníticos Cunhaporanga e Três Córregos, Estado do Paraná. Dissertação de Mestrado- IGc-USP, 180p.

PRAZERES FILHO, H. J.; HARARA, O.M.M.; BASEI, M.A.S.; PASSARELI, C.R.; SIGA JUNIOR, O. 2003. Litogeoquímica, Geocronologia U-Pb e Geologia Isotópica (Sm$\mathrm{Nd}-\mathrm{Pb}$ ) das rochas graníticas dos Batólitos Cunhaporanga e Três Córregos, na porção sul do Cinturão Ribeira, Estado do Paraná. Geologia USP, Série Científica, SP, v.3, p. 51-70.

PRAZERES FILHO, H. 2005. Caracterização geológica e petrogenética do Batólito Granítico Três Córregos (PR-SP): Geoquímica Isotópica (Nd-Sr-Pb. Idades (ID-TIMS / SHRIMP) e O18 em zircão. Tese de doutoramento (inédita). São Paulo: IGc-USP, 207p.

REIS NETO, J. M.; SOARES, P. C. 1987. Um estudo da caracterização termo-dinâmica de micro estruturas dos Grupos Açungui e Setuva (PR). In: III Simpósio Sul Brasileiro de Geologia, Curitiba, Atas, v.1, p. 147-165.

REIS NETO, J.M. 1994. Faixa Itaiacoca: registro de uma colisão entre dois blocos continentais no neoproterozóico. Tese de doutoramento (inédita). São Paulo: IG/USP, 253 p.

RIBEIRO, L. M. A. L. ; SIGA JUNIOR, O. 2005. Estudo Geológico e Geocronológico do Núcleo Betara: Implicações tectônicas. In: X Simpósio Nacional de Estudos Tectônicos SNET, Curitiba. v.1, p. 378-380.

RICHARD, L.R. 1995. Minpet for Windows - Version 2.02 - Reference Manual. Minpet Geologic Software, Quèbec Canada. 
ROLLINSON, H.R. - 1993 Using geochemical data: evaluation, presentation, interpretation. Longman Scientific \& Technical. 352p.

ROLLINSON, H.R.; ROBERTS, C.R. -1986- Ratio correlation and major element mobility in altered basalts and komatiites - reply tp K.J.Vines. Contrib. Mineral. Petrol. 97: $527-528$

SALAMUNI, E. 1991. Análise estrutural do Núcleo Betara, Rio Branco do Sul (PR). Dissertação de Mestrado. Rio Claro - UNESP, 147p.

SALAMUNI,E.; FIORI, A.P.; WERNICK, E. 1992. Evolução Tectônica e estruturação do Núcleo Betara, arredores de Curitiba - PR. In: Congr. Bras. de Geol., Anais, v.1, p. 280.

SALAMUNI, E.; FIORI, A.P.; WERNICKE. 1993. Características estruturais e evolução tectônica do Núcleo Betara a norte de Curitiba (PR). Bol. Par. Geoc., 41: p. 91-127

SALAMUNI, E. 1995. Dobramentos e redobramentos na porção sul da Zona de Cisalhamentos Lancinha-Cubatão. V Simpósio Nacional de Estudos Tectônicos - SNET, Anais, p. 78-80.

SATO, K. 1998. Evolução Crustal da plataforma sul-americana com base na geoquímica isotópica Sm-Nd. Tese de Doutoramento, IGc-USP.

SATO, K.; TASSINARI, C.G.; KAWASHITA, K.; PETRONILHO, L. 1995. O método Sm-Nd no IGc-USP e suas aplicações. Anais da Academia Brasileira de Ciências, 67, p. 313-336.

SATO, K.; SIGA JUNIOR, O.; BASEI, M.A.S.; NUTMAN, A.P.2001. Conventional Leaching Technique and partial digestion in microwave oven: treatment procedures for U$\mathrm{Pb}$ dating of overgrow Zircom roms by thermal ionization mass spectrometry (TIMS). III SSAGI, Pucon, Chile.

SATO, K.; KAWASHITA,K. 2002. Espectrometria de massas em geologia isotópica. Revista do IGc-USP, Série Cient., v.2, p. 57-77.

SCHÖLL, W.U.; LOPES, O.M.; SILVA, A.C.G.A.; PROZZI, C.R. 1980. Geologia do PréCambriano da Anticlinal do Setuva (Município de Bocaiúva do Sul e Rio Branco do Sul PR). In: CONGR. BRAS. DE GEOLGIA, 31. Anais... Balneário de Camboriú, SBG. v. 5, p. 3003-3012.

SCHÖLL, W.U. 1981. Geologia do grupo Açungui na Região noroeste de Rio Branco do Sul, Paraná. In: SIMP. REG. DE GEOLOGIA, 3, Curitiba, SBG. v. 1, p. 170-184.

SCHÖLL, W.U.; SILVA, A.C.G.A.; MONASTIER, M.S. 1982. A Formação Setuva do Pré-Cambriano do Estado do Paraná. In: CONGR. BRAS. DE GEOLOGIA. 32. Anais... Salvador, SBG. v. 1, p. 55-63. 
SENGOR, A.M.C.; DEWEY, F.R.S. 1990. Terranology, Vice or Virtue? Phil. Trans. R. Soc. Lond., 331: 457-477.

SIGA JUNIOR, O. 1995. Domínios tectônicos do sudeste do Paraná e nordeste de Santa Catarina. Geocronologia e evolução crustal. Tese de doutoramento. São Paulo, IGc-USP, $212 \mathrm{p}$.

SIGA JUNIOR, O.; BASEI, M.A.S.;REIS NETO, J.M.; MACHIAVELLI, A.; HARARA, O.M.M. 1995. O Complexo Atuba: um cinturaõ Paleoproterozóico intensamente retrabalhado no Neoproterozóico. Boletim IG-USP, Série Científica, v. 26, p. 69-98.

SIGA JR., O.; WEBER, W.; BASEI, M.A.S.; SATO, K.; REIS NETO, J.M. 2002. O Grupo Itaiacoca: registro de uma bacia neoproterozóica. In: CONG. BRAS. DE GEOLOGIA, 41. SBG-NO. p.510.

SIGA JR., O.; BASEI, M.A.S.; SATO, K.; PRAZERES FILHO, H.J.; CURY, L. F.; WEBER, W.; PASSARELLI, C.R.; HARARA, O.M.; REIS NETO, J. M. 2003 a. U-PB (zircon) ages of metavolcanic rocks from the Itaiacoca Group: tectonic implications. Revista Geologia IGc- USP, Série Científica, v.3., p. 39-49.

SIGA JR., O.; KAULFUSS, G.A.; SATO, K.; BASEI, M.A.S.; REIS NETO, J.M. 2003 b. The geochronology of the Setuva Nucleous: policyclic terrains exposed to upper crustal levels during the Neoproterozoic. In: IV SSAGI, Salvador- Ba,v. 2, p.683.

SIGA JÚNIOR, O.; CURY, L.F.; KAULFUSS, G.A. HARARA, O.M.M.; SATO, K.; RIBEIRO, L. M. A. L.; BASEI, M.A.S. 2005. Evidências de Regimes Extensionais do Estateriano no leste paranaense, com base em estudos geocronológicos. In X Simpósio Nacional de Estudos Tectônicos - SNET. Curitiba, v.1, p. 353-356.

SIGA JUNIOR, O.; BASEI, M.A.S.; HARARA, O.M.M.; PASSARELLI, C.R.; CURY, L.F.; SATO, K. 2006. Lithostratigraphy and Geochronology of the Itaiacoca Belt (ParanáBrazil): Records of Mesoproterozoic and Neoproterozoic Sequences. Journal of South American Earth Sciences. No prelo.

SILVA, P.C.S.; YAMATO, A.A.; VASCONCELOS, C.S.; LOPES JR., I. 1998. Projeto Folha Curitiba (SG. 22-X-D-I): relatório final. São Paulo, 91 p. (mapas).

SILVA, A.T.S.F.; ALGARTE, J.P. 1981. Contribuição à Geologia da Sequência TurvoCajati entre o Rio Pardo e Pariquera-Açu, Estado de São Paulo: Litologia e Petrografia. Simp. Reg. Geol., 3, Curitiba, Atas, SBG, v. 1, p. 109-120.

SOARES, P.C. 1987. Seqüências tectono-sedimentares e tectônica deformadora no centrooeste do escudo paranaense. In: SIMP SUL. BRAS. DE GEOLOGIA, 3. Atas... Curitiba, SBG, v. 2, p. 743-771. 
SOARES, P.C.; FIORI, A.P.; ROSTIROLLA, S.P. 1998. Organização estratigráfica e estrutural dos terrenos alóctones no Cinturão Ribeira, no Vale do Ribeira (PR-SP). In: $40^{\circ}$ Congresso Bras. de Geol., Belo Horizonte, Anais, p. 41.

SOARES, P.C.; ROSTIROLLA, S.P.1997. Tectõnica de escape transcolisional nos Cinturões Ribeira e Dom Feliciano. In: VI Simpósio Nacional de Estudos Tectõnicos SNET Pirinópolis, MG. Anais, p. 65-68.

STEIGER, R.H.; JAGER,E. 1978. Subcomission on geochronology: convention on the use of decay constants in geochronology. Contribution to the geologic time scale, Studies in geology, v.6, p. 67-72.

SZABÓ, G.A.J - 1996 - Petrologia da suíte metaultramáfica da seqüência vucanosedimentar do Morro do Ferro na região de sul a oeste de Alpinópolis, MG (domínio norte do Complexo Campos Gerais). Tese de Doutoramento (inédita). São Paulo, Igc-USP, 354p.

TAKAHASHI, A.T.1981. Projeto integração e detalhe do Vale do Ribeira, área Ribeirão do Perau. São Paulo. Convênio DNPM/CPRM.

TASSINARI, C.C.G; BARBOUR, A.;DAITX, E.C.; SATO; K. 1990. Aplicação dos isótopos de $\mathrm{Pb}$ e $\mathrm{Sr}$ na determinação da natureza das fontes das mineralizações de chumbo do Vale do Ribeira. In: CONG. BRAS. DE GEOLOGIA, 35. Anais... Natal, SBG, v.3, p. 1254-1266.

THOMPSON, G. 1973. A geochemical study of the low temperature interaction of seawater and oceanic igneous rocks. EOS Trans. Am. Geophys. Union, v. 54, p. 1015-1018.

TREIN, E.; REIS NETO, J.M.; BIONDI, J.C.; MONASTIER, M.S. 1985. Revisão da Formação Itaiacoca: identificação de uma sequência metavulcanossedimentar em Abapã (PR). In: SBG $5^{\circ}$ Simpósio Regional de Geologia, São Paulo, Atas, v.1, p. 169-186.

TRÖGER, W.E. 1979. Optical determination of Rock-forming minerals (Part 1 Determination tables). Versão em inglês da $4^{a}$ edição alemã por Bambauer, H.U.; Taborzky, F.; Trochim, H. D. - E. Schweizerbat'sche Verlagsbuchhandlung, Stuggart, 188p.

VINES, K.J. - 1987- Comments on "Ratio correlation and major element mobility in alteres basalts e komatiites" by H.R. Rollinson and C. R. Roberts. Contrib. Mineral.Petrol. 97:525-526

WEBER, W.; SIGA Jr.,O.; SATO, K.; BASEI, M.A.S.; REIS NETO, J.M. 2003. U-Pb (zircon) ages of metabasic rocks of the Água Clara Formation in the Araçaíba region-SPBrazil: preliminary data. In: IV SSAGI, Salvador- BA, p. 706-709.

YAMATO, A.A. 1999. Mapeamento geológico de parte da Folha Bocaiúva do Sul (SG.22$X$-D-I-2), escala 1:50.000. Dissertação de mestrado (inédita). IG-USP, São Paulo, 108p. 
WATSON, E. B.; HARRISON, M. 1983. Zircon saturation revisited: temperature and composition effects in a variety of crustal magam types. Earth and Planetary Science Letters, 64, p. 295-304.

WOOD, S. A. 1990. The aqueous geochemistry of the rare earth elements and ytriun. 1. Review of available low-temperature data for inorganic complexes and inorganic REE speciation of natural waters. Chemical Geology, Amsterdam - Netherlands, v. 82, p. 159196.

WOOD, D.A.; GIBSON, I.L.; THOMPSON, R.N. 1976. Elemental mobility during zeolit facies metamorphism of the tertiary basalts of Easthern Iceland. Contrib. Mineral. Petrol. V. 55, p. 241-254. 


\section{Anexo 1 \\ Tabelas das análises geoquímicas}




\begin{tabular}{|c|c|c|c|c|c|c|c|c|}
\hline & LBT-07A & LBT-09A & LBT-09B & LBT-13 & & LBT-17A & LBT-17B & LBT-20 \\
\hline & $40 / 04 / 219$ & $40 / 04 / 221$ & $40 / 04 / 222$ & $40 / 04 / 223 a$ & $40 / 04 / 223 \mathrm{~b}$ & $40 / 04 / 224$ & $40 / 04 / 225$ & $40 / 04 / 226$ \\
\hline SiO2 & 48,86 & 47,04 & 47,77 & 72,06 & 72,60 & 47,87 & 47,66 & 49,17 \\
\hline Al2O3 & 13,14 & 13,70 & 10,85 & 14,52 & 14,56 & 12,01 & 9,39 & 15,23 \\
\hline MnO & 0,181 & 0,157 & 0,171 & 0,032 & 0,030 & 0,178 & 0,203 & 0,188 \\
\hline MgO & 9,83 & 11,23 & 13,44 & 0,41 & 0,41 & 11,89 & 13,92 & 7,81 \\
\hline $\mathrm{CaO}$ & 13,47 & 15,98 & 14,20 & 1,67 & 1,69 & 13,10 & 12,59 & 12,42 \\
\hline $\mathrm{Na2O}$ & 1,43 & 0,34 & 0,29 & 4,75 & 4,74 & 0,79 & 0,36 & 2,42 \\
\hline K2O & 0,11 & 0,03 & 0,02 & 2,66 & 2,66 & 0,12 & 0,11 & 0,27 \\
\hline TiO2 & 0,675 & 0,402 & 0,500 & 0,219 & 0,221 & 0,646 & 0,677 & 0,712 \\
\hline P2O5 & 0,050 & 0,017 & 0,027 & 0,036 & 0,037 & 0,038 & 0,040 & 0,053 \\
\hline $\mathrm{Fe} 2 \mathrm{O} 3$ & 10,39 & 9,31 & 10,37 & 1,90 & 1,89 & 10,88 & 12,31 & 10,27 \\
\hline Loi & 1,68 & 1,97 & 2,27 & 1,11 & 1,11 & 2,40 & 2,33 & 1,55 \\
\hline Total & 99,82 & 100,18 & 99,91 & 99,37 & 99,95 & 99,92 & 99,59 & 100,09 \\
\hline & & & & & & & & \\
\hline $\mathrm{Ba}$ & 19 & $<17$ & $<17$ & 1190 & 1205 & 76 & 38 & 52 \\
\hline $\mathrm{Ce}$ & $<18$ & $<18$ & $<18$ & 109 & 96 & $<18$ & $<18$ & $<18$ \\
\hline Cl & $<15$ & $<15$ & 290 & $<15$ & $<15$ & $<15$ & $<15$ & $<15$ \\
\hline Co & 56 & 53 & 65 & 38 & 39 & 60 & 74 & 53 \\
\hline $\mathrm{Cr}$ & 287 & 759 & 899 & 4 & 3 & 715 & 782 & 181 \\
\hline $\mathrm{Cu}$ & 135 & 27 & 39 & 15 & 15 & 40 & 123 & 53 \\
\hline $\mathbf{F}$ & $<223$ & $<223$ & 336 & $<223$ & 235 & 229 & $<223$ & $<223$ \\
\hline $\mathbf{G a}$ & 14 & 13 & 11 & 13 & 14 & 13 & 10 & 18 \\
\hline La & 1 & 15 & $<14$ & 61 & 70 & $<14$ & $<14$ & $<14$ \\
\hline $\mathbf{N b}$ & 4 & 5 & 4 & 15 & 15 & 5 & 4 & 5 \\
\hline Nd & $<22$ & $<22$ & $<22$ & 29 & 33 & $<22$ & $<22$ & $<22$ \\
\hline $\mathbf{N i}$ & 114 & 183 & 229 & 5 & 6 & 231 & 276 & 94 \\
\hline $\mathbf{P b}$ & $<5$ & 8 & 23 & 22 & 22 & 16 & 9 & 8 \\
\hline $\mathbf{R b}$ & 5 & 3 & 2 & 52 & 52 & 5 & 5 & 7 \\
\hline $\mathbf{S}$ & $<100$ & $<100$ & $<100$ & $<100$ & $<100$ & $<100$ & $<100$ & $<100$ \\
\hline Sc & 52 & 51 & 53 & $<4$ & $<4$ & 45 & 48 & 43 \\
\hline Sr & 132 & 169 & 140 & 357 & 357 & 266 & 196 & 181 \\
\hline Th & 7 & 5 & 3 & 20 & 20 & 7 & 6 & 8 \\
\hline U & $<3$ & $<3$ & $<3$ & $<3$ & $<3$ & $<3$ & $<3$ & $<3$ \\
\hline $\mathbf{V}$ & 241 & 189 & 209 & 16 & 18 & 218 & 224 & 257 \\
\hline $\mathbf{Y}$ & 14 & 11 & 12 & 8 & 9 & 13 & 14 & 16 \\
\hline $\mathbf{Z n}$ & 57 & 49 & 56 & 12 & 12 & 80 & 89 & 66 \\
\hline
\end{tabular}

Análises químicas para elementos maiores, menores e traços das rochas metabásicas da Região do Betara - Laboratório de Fluorescência de Raios X -IGc - USP 


\begin{tabular}{|c|c|c|c|c|c|c|c|}
\hline N. Lab. & & $04 / 0219$ & $04 / 0221$ & $04 / 0222$ & $04 / 0224$ & $04 / 0225$ & $04 / 0226$ \\
\hline N. Campo & & $L B T-7 A$ & LBT-9A & LBT-9B & $L B T-17 A$ & $L B T-17 B$ & LBT-20 \\
\hline $\mathrm{Rb}$ & 85 & 4,10 & 0,93 & 1,08 & 4,21 & 2,98 & 6,55 \\
\hline $\mathrm{Y}$ & 89 & 12,3 & 8,71 & 11,1 & 12,1 & 11,4 & \begin{tabular}{|l|}
15,3 \\
\end{tabular} \\
\hline $\mathrm{Zr}$ & 90 & 15,2 & 7,84 & 8,17 & 10,1 & 12,9 & 12,3 \\
\hline $\mathrm{Nb}$ & 93 & 3,04 & 1,17 & 1,21 & 1,88 & 1,66 & 3,31 \\
\hline Cs & 133 & 0,20 & 0,07 & 0,08 & 0,20 & 0,17 & 0,34 \\
\hline $\mathrm{Ba}$ & 135 & 22,6 & 8,16 & 9,16 & 67,2 & 48,5 & 57,8 \\
\hline $\mathrm{La}$ & 139 & 2,14 & 1,63 & 2,29 & 2,09 & 1,51 & 3,27 \\
\hline $\mathrm{Ce}$ & 140 & 5,22 & 2,75 & 3,29 & 4,85 & 4,04 & 6,56 \\
\hline $\mathrm{Pr}$ & 141 & 0,83 & 0,60 & |0,84 & 0,80 & 0,69 & 1,02 \\
\hline $\mathrm{Nd}$ & 143 & 4,44 & 3,19 & 4,39 & 4,31 & 3,87 & 5,31 \\
\hline $\mathrm{Sm}$ & 147 & 1,52 & 1,16 & 1,48 & 1,51 & 1,42 & 1,74 \\
\hline $\mathrm{Eu}$ & 151 & 0,59 & 0,47 & 0,54 & 0,63 & 0,43 & 0,85 \\
\hline $\mathrm{Gd}$ & 157 & 1,95 & 1,31 & 1,83 & 1,93 & 1,81 & 2,15 \\
\hline $\mathrm{Tb}$ & 159 & 0,32 & 0,23 & 0,30 & 0,32 & 0,31 & 0,37 \\
\hline Dy & 161 & 2,08 & 1,47 & 1,90 & 2,02 & 2,00 & 2,39 \\
\hline Ho & 165 & 0,48 & 0,33 & \begin{tabular}{|l|}
0,43 \\
\end{tabular} & 0,46 & 0,45 & 0,54 \\
\hline Er & 166 & 1,38 & 0,92 & 1,19 & 1,31 & 1,26 & 1,58 \\
\hline $\mathrm{Tm}$ & 169 & 0,20 & 0,13 & 0,17 & 0,19 & 0,18 & 0,22 \\
\hline $\mathrm{Yb}$ & 173 & 1,25 & 0,84 & 1,04 & 1,19 & 1,11 & 1,41 \\
\hline $\mathrm{Lu}$ & 175 & 0,17 & 0,11 & 0,14 & 0,15 & 0,15 & 0,18 \\
\hline $\mathrm{Hf}$ & 179 & 0,57 & 0,27 & 0,35 & \begin{tabular}{|c|}
0,39 \\
\end{tabular} & 0,47 & 0,45 \\
\hline $\mathrm{Ta}$ & 181 & 1,40 & 0,72 & 0,43 & 0,42 & 0,31 & 1,72 \\
\hline $\mathrm{Pb}$ & média & 1,54 & 3,59 & 2,25 & 12,4 & 7,40 & 8,38 \\
\hline Th & 232 & 0,24 & 0,12 & 0,14 & 0,20 & 0,18 & 0,20 \\
\hline $\mathrm{U}$ & 238 & 0,05 & 0,02 & 0,02 & 0,04 & 0,03 & 0,04 \\
\hline
\end{tabular}

Valores para alguns elementos menorees e elementos terras raras de rochas metabásicas da Região do Betara - Laboratório de Química e ICP-IGc-USP. 


\section{Anexo 2 \\ Tabela das Análises Sm-Nd \& Sr-Sr}




\begin{tabular}{|c|c|c|c|c|c|c|c|c|c|c|c|c|}
\hline SPS & No. Campo & Material & $\begin{array}{c}\mathrm{Sm} \\
(\mathrm{ppm})\end{array}$ & $\begin{array}{c}\mathrm{Nd} \\
(\mathrm{ppm})\end{array}$ & ${ }^{47} \mathrm{Sm} /{ }^{144} \mathrm{Nc}$ & ${ }^{43} \mathrm{Nd} /{ }^{144} \mathrm{Nd}$ & $8_{(0)}$ & $\mathbf{f}_{\mathrm{Sm} / \mathrm{Nd}}$ & $\mathrm{T}_{\mathrm{DM}}(\mathrm{Ma})$ & $8_{\text {(TDM) }}$ & $\begin{array}{c}\mathrm{T}_{1} \\
(\mathrm{Ma})\end{array}$ & $8_{(\mathrm{T} 1)}$ \\
\hline 3564 & LBT-17A C13 & $\begin{array}{c}\text { RTOT/Meta } \\
\text { básica }\end{array}$ & 1,387 & 4,068 & 0,2061 & 0,512857 & 4,28 & 0,05 & \#NÚM! & \#NÚM! & 1400,0 & 2,60 \\
\hline 3565 & LBT-17B C13 & $\begin{array}{c}\text { RTOT/Meta } \\
\text { básica }\end{array}$ & 1,336 & 3,678 & 0,2197 & 0,512978 & 6,64 & 0,12 & \#NÚM! & \#NÚM! & 1400,0 & 2,53 \\
\hline 3566 & LBT-20 C13 & $\begin{array}{c}\text { RTOT/Meta } \\
\text { básica }\end{array}$ & 1,644 & 4,967 & 0,2002 & 0,512790 & 2,97 & 0,02 & 3095,8 & 1,61 & 1400,0 & 2,36 \\
\hline 3559 & LBT-7A C13 & $\begin{array}{c}\text { RTOT/Meta } \\
\text { básica }\end{array}$ & 1,435 & 4,213 & 0,2060 & 0,512825 & 3,65 & 0,05 & \#NÚM! & \#NÚM! & 1400,0 & 2,00 \\
\hline 3560 & LBT-7B C13 & $\begin{array}{c}\text { RTOT/Meta } \\
\text { básica }\end{array}$ & 6,572 & 28,757 & 0,1382 & 0,512367 & $-5,28$ & $-0,30$ & 1361,1 & 4,88 & 1400,0 & 5,17 \\
\hline 3561 & LBT-9A C13 & $\begin{array}{c}\text { RTOT/Meta } \\
\text { básica }\end{array}$ & 1,030 & 3,001 & 0,2074 & 0,512951 & 6,11 & 0,05 & 2226,3 & 3,06 & 1400,0 & 4,19 \\
\hline 3562 & LBT-9B C13 & $\begin{array}{c}\text { RTOT/Meta } \\
\text { básica }\end{array}$ & 1,376 & 4,194 & 0,1985 & 0,512894 & 5,00 & 0,01 & 1449,8 & 4,68 & 1400,0 & 4,69 \\
\hline
\end{tabular}

Valores para as análises geocronológicas $\mathrm{Sm}-\mathrm{Nd}$ relativas às rochas metaásicas da Região do Betara

\begin{tabular}{|c|c|c|c|c|c|c|c|c|c|c|c|c|c|}
\hline SPR & No. Campo & Material & $\mathbf{R b}$ & $\mathrm{Sr}$ & ${ }^{87} \mathrm{Rb} /{ }^{86} \mathrm{Sr}$ & $\left.{ }^{87} \mathrm{Sr}\right|^{86} \mathrm{Sr}$ & $\varepsilon_{(0)}$ & $\mathrm{T}_{\mathrm{DM}}(\mathrm{Ma})$ & $\varepsilon_{(\mathrm{TDM})}$ & $\mathbf{T}_{1}$ & $\varepsilon_{(\mathrm{T} 1)}$ & ${ }^{87} \mathrm{Sr} l^{86} \mathrm{Sr}$ & $\varepsilon_{(\mathrm{T} 2)}$ \\
\hline & & & (ppm) & (ppm) & & & & & & (Ma) & \multicolumn{3}{|c|}{$(T=1400 M a)}$. \\
\hline 3564 & LBT-17A C13 & $\begin{array}{c}\text { RTOT/Met } \\
\text { abásica }\end{array}$ & 3,73 & 274,35 & 0,0394 & 0,71534 & 153,81 & \#NÚM! & \#NÚM! & 1400,0 & 166,23 & 0,71 & 153,82 \\
\hline 3565 & LBT-17B C13 & $\begin{array}{c}\mathrm{RTOT} / \mathrm{Met} \\
\text { abásica }\end{array}$ & 2,65 & 200,87 & 0,0383 & 0,71419 & 137,52 & \#NÚM! & \#NÚM! & 1400,0 & 150,21 & 0,71 & 137,52 \\
\hline 3566 & LBT-20 C13 & $\begin{array}{c}\text { RTOT/Met } \\
\text { abásica } \\
\end{array}$ & 4,42 & 172,79 & 0,0741 & 0,72019 & 222,64 & 38303,8 & 326,43 & 1400,0 & 225,29 & 0,72 & 222,64 \\
\hline 3559 & LBT-7A C13 & $\begin{array}{c}\text { RTOT/Met } \\
\text { abásica } \\
\end{array}$ & 3,37 & 130,43 & 0,0748 & 0,71209 & 107,75 & 22945,5 & 151,58 & 1400,0 & 109,94 & 0,71 & 107,75 \\
\hline 3560 & LBT-7B C13 & $\begin{array}{c}\text { RTOT/Met } \\
\text { abásica }\end{array}$ & 24,04 & 386,85 & 0,1799 & 0,70725 & 38,98 & 2620,5 & $-13,96$ & 1400,0 & 11,00 & 0,70 & 38,96 \\
\hline 3561 & LBT-9A C13 & $\begin{array}{c}\text { RTOT/Met } \\
\text { abásica } \\
\end{array}$ & 0,49 & 169,03 & 0,0083 & 0,71423 & 138,15 & $-24170,2$ & $-158,67$ & 1400,0 & 159,41 & 0,71 & 138,17 \\
\hline 3562 & LBT-9B C13 & $\begin{array}{c}\text { RTOT/Met } \\
\text { abásica }\end{array}$ & 0,88 & 143,89 & 0,0178 & 0,71918 & 208,42 & $-53822,5$ & $-259,40$ & 1400,0 & 227,13 & 0,72 & 208,43 \\
\hline
\end{tabular}

Valores para as análises geocronológicas $\mathrm{Rb}$-Sr relativas às rochas metaásicas da Região do Betara 


\section{Anexo 3 \\ Tabela das Análises U-Pb em zircão}




\begin{tabular}{|c|c|c|c|c|c|c|c|c|c|c|c|c|c|}
\hline SPU & Magnetic & Mineral & 207/235\# & Error & 206/238\# & Error & COEF. & $238 / 206$ & Error & 207/206\# & Error & $206 / 204^{*}$ & $\mathrm{~Pb}$ \\
\hline & Anfidisses & -Pb zīyed dypara & as roch & ast quiet & abásicas & a roeg & ão do & Betara & $(\%)$ & & $(\%)$ & & (ppm) \\
\hline Amostra & LBT 7A & & & & & & & & & & & & \\
\hline 2726 & $\mathrm{NM}(-2) \mathrm{A}$ & & 3,27794 & 0,61 & 0,255001 & 0,594 & 0,9765 & 3,921553 & 0,594 & 0,093231 & 0,131 & 1367,7 & 64,5 \\
\hline 2727 & $\mathrm{NM}(-2) \mathrm{b}$ & & 3,31821 & 0,535 & 0,256285 & 0,528 & 0,9862 & 3,901906 & 0,528 & 0,093903 & 0,0885 & 1703,6 & 49,3 \\
\hline 2729 & $\mathrm{NM}(-2) \mathrm{d}$ & & 3,22825 & 0,46 & 0,252302 & 0,457 & 0,9932 & 3,963504 & 0,457 & 0,0928 & 0,0534 & 8820,5 & 132,7 \\
\hline 2730 & $\mathrm{M}(-2) \mathrm{a}$ & & 3,2725 & 0,463 & 0,254628 & 0,46 & 0,992 & 3,927298 & 0,46 & 0,093212 & 0,0584 & 4612,9 & 84,4 \\
\hline 2812 & $\mathrm{M}(-2) \mathrm{b}$ & & 3,26951 & 0,473 & 0,255684 & 0,466 & 0,9855 & 3,911078 & 0,466 & 0,092742 & 0,0802 & 5548,292 & 157,59 \\
\hline 2728 & $\mathrm{NM}(-2) \mathrm{c}$ & & 1,45278 & 0,662 & 0,135475 & 0,643 & 0,9734 & 7,381436 & 0,643 & 0,077775 & 0,152 & 622,2 & 20,6 \\
\hline
\end{tabular}
LBT - 9

\begin{tabular}{|c|c|c|c|c|c|c|c|c|c|c|c|c|}
\hline 2787 & $\mathrm{M}-1 \mathrm{~A}$ & 7,1627 & 1,14 & 0,391108 & 1,13 & 0,988463 & 2,556839 & 1,13 & 0,132825 & o,173 & 857,8309 & 77,827 \\
\hline 2788 & $M-1 B$ & 9,80139 & 0,54 & 0,424805 & 0,53 & 0,982836 & 2,354021 & 0,53 & 0,167339 & 0,0997 & 3923,158 & 75,789 \\
\hline 2789 & $M-1 C$ & 7,70631 & 1,06 & 0,346186 & 1,06 & 0,994437 & 2,888621 & 1,06 & 0,161449 & 0,112 & 822,6415 & 606,36 \\
\hline 2790 & $M-1 D$ & 3,41273 & 1,44 & 0,258624 & 1,42 & 0,989925 & 3,866617 & 1,42 & 0,095704 & 0,203 & 647,1939 & 24,557 \\
\hline 2803 & $M-1 G$ & 13,2613 & 2,26 & 0,518635 & 1,32 & 0,61563 & 1,928138 & 1,32 & 0,185449 & 1,78 & 78,05902 & 2,6155 \\
\hline
\end{tabular}

\section{LBT 12}

\begin{tabular}{|c|c|c|c|c|c|c|c|c|c|c|c|c|c|}
\hline 2792 & NM-1 A & & 4,74256 & 1,15 & 0,313083 & 1,14 & 0,991545 & 3,194041 & 1,14 & 0,109863 & 0,149 & 626,4548 & 37,451 \\
\hline 2793 & NM-1 B & & 4,62295 & 0,557 & 0,311065 & 0,553 & 0,992599 & 3,214762 & 0,553 & $\begin{array}{l}0,107787 \\
\end{array}$ & 0,0677 & 2631,825 & 37,458 \\
\hline 2795 & NM-1 D & & 4,5099 & 0,637 & 0,302945 & 0,626 & 0,983765 & 3,300929 & 0,626 & $\begin{array}{l}0,10797 \\
\end{array}$ & 0,114 & 1900,741 & 61,208 \\
\hline 2796 & NM-1 E & & 4,7033 & 1,53 & 0,309079 & 1,52 & 0,990298 & 3,235419 & 1,52 & 0,110365 & 0,213 & 574,4818 & 313,36 \\
\hline 2815 & NM-2F & & 4,70483 & 1,13 & 0,312388 & 1,09 & 0,96473 & 3,201147 & 1,09 & 0,109232 & 0,297 & 614,1303 & 40,339 \\
\hline 2816 & NM-2G & & 4,88749 & 1,46 & 0,326318 & 1,31 & 0,91117 & 3,064495 & 1,31 & 0,108628 & 0,601 & 623,134 & 37,759 \\
\hline 2817 & $\mathrm{NM}-2 \mathrm{H}$ & & 4,84495 & 1,43 & 0,313325 & 1,38 & 0,96757 & 3,191574 & 1,38 & 0,112148 & 0,361 & 387,9679 & 1,8791 \\
\hline 2819 & NM-1J & & 4,8571 & 0,891 & 0,316338 & 0,849 & 0,95716 & 3,161176 & 0,849 & 0,111359 & 0,258 & 486,76 & 16,096 \\
\hline 2794 & NM-1 C & & 1,29784 & 0,534 & 0,105655 & 0,497 & 0,939464 & 9,464767 & 0,497 & 0,08909 & 0,183 & 4036,965 & 51,573 \\
\hline 2818 & NM-1I & & 2,2891 & 0,807 & 0,164673 & 0,782 & $\begin{array}{l}0,96951 \\
\end{array}$ & 6,072641 & 0,782 & 0,100819 & 0,198 & 363,6532 & 9,5881 \\
\hline \multicolumn{14}{|l|}{ LBT 13} \\
\hline 2797 & NM-2 A & & 7,9266 & 0,615 & 0,40389 & 0,612 & 0,99322 & 2,475922 & 0,612 & 0,142339 & 0,0715 & 2102,013 & 69,424 \\
\hline 2799 & NM-2 C & $(206 / 208$ SPU 2800$)$ & 5,29731 & 1,05 & 0,307829 & 1,04 & 0,99148 & 3,248557 & 1,04 & 0,124809 & 1,36 & 846,809 & 71,243 \\
\hline 2800 & NM-2 D & & 11,8401 & 0,698 & 0,470095 & 0,693 & 0,98999 & 2,12723 & 0,693 & 0,182671 & 0,0985 & 1947,896 & 97,707 \\
\hline 2813 & NM-2E & & 2,31859 & 0,467 & 0,108167 & 0,467 & 0,9804 & 9,244964 & 0,467 & 0,155464 & 0,0939 & 4817,914 & 10,81 \\
\hline 2814 & NM-2F & & 13,2253 & 0,501 & 0,497841 & 0,477 & 0,96098 & 2,008673 & 0,477 & 0,19267 & 0,139 & 2750 & 89,794 \\
\hline
\end{tabular}

\section{LBT 20}

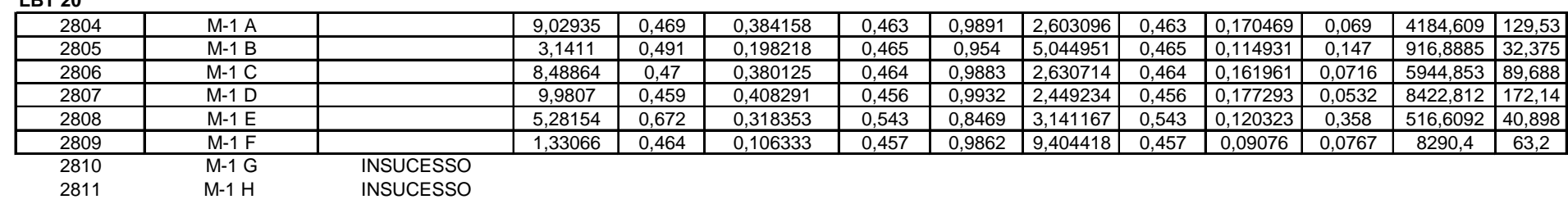

LEGENDA

SPU: laboratory number

Magnetic fractions: numbers in parentheses indicated the tilt used on Frantz separator at $1.5 \mathrm{amp}$. current

\# Radiogenic $\mathrm{Pb}$ corrected for blank and initial $\mathrm{Pb}$; $\mathrm{U}$ corrected for blank;

* Not corrected for blank or non-radiogenic Pb

Total $\mathrm{U}$ and $\mathrm{Pb}$ concentrations corrected for analytical blank

Ages: given in Ma using Ludwig Isoplot/Ex program (1998), decay constants recommended by Steiger and Jäger (1977). TIPOLOGIA - ZIRCÃO

\begin{tabular}{|c|c|c|c|c|c|}
\hline \multicolumn{2}{|r|}{ FORMA } & \multicolumn{2}{|r|}{ COR/TRANSPARÊNCIA } & \multicolumn{2}{|r|}{ CARACTERÍSTICAS INTERNAS } \\
\hline$P(x / y)$ & Cristal prismático (comprimento/largura) & $\mathrm{T}$ & Cristal transparente & $\mathrm{Cl}$ & Cristal sem ou com raras inclusões ou fraturas \\
\hline $\operatorname{Pr}(x / y)$ & Cristal prism.c/ faces e arestas arredondadas & $\mathrm{Ot}$ & Cristal opaco ou translúcido & 1 & Cristal com inclusões frequentes \\
\hline $\mathrm{Dt}$ & Cristal prism.c/ bi-terminação bem desenvolvida & $\mathrm{C}$ & \begin{tabular}{|l|l|} 
Cristal incolor \\
\end{tabular} & $\mathrm{F}$ & Cristal com fraturas frequentes \\
\hline Py & Cristal prism.c/ faces piramidais bem desenvolvidas & & & $\mathrm{Mz}$ & Cristal com zoneamento magmático \\
\hline $\mathrm{M}$ & Cristal multifacetado & & & & \\
\hline $\mathrm{Tb}$ & Cristal com tendência tabular (altura $<<$ largura) & & & & \\
\hline $\mathrm{R}$ & Cristal com tendência esférica & & & & \\
\hline $\mathrm{Fr}$ & Cristal em fragmentos & & & & \\
\hline
\end{tabular}




\section{Anexo 4 Mapa Geológico - Escala 1: 100.000}

